\title{
BASELINE RISK ASSESSMENT OF Ground Water Contamination AT THE MONUMENT VALLEY URANIUM MILL TAILINGS SITE Cane Valley, Arizona
}

March 1996
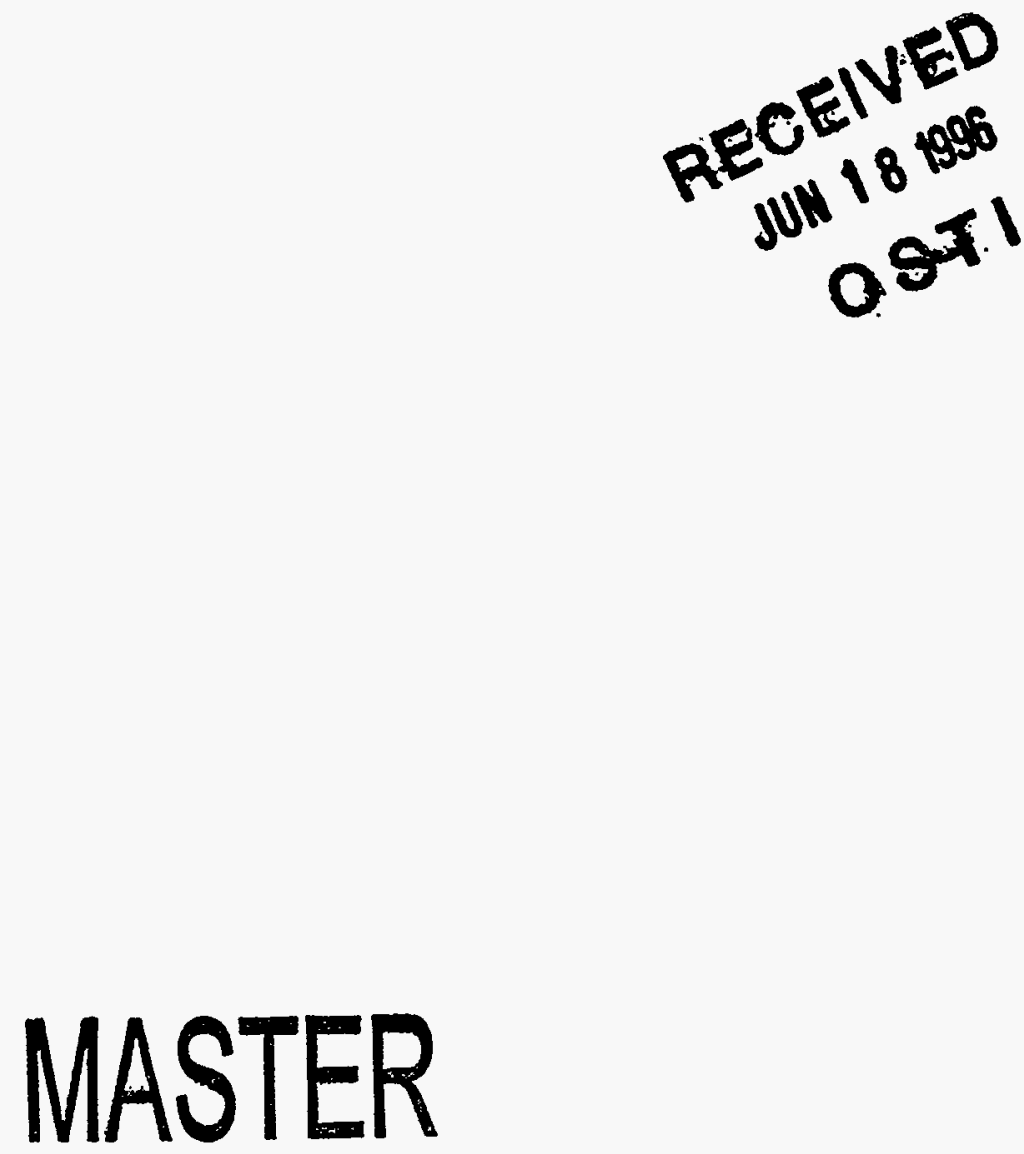
INTENDED FOR PUBLIC RELEASE

This report has been reproduced from the best available copy. Available in paper copy and microfiche

Number of pages in this report: 160

DOE and DOE contractors can obtain copies of this report from:

Office of Scientific and Technical Information

P.0. Box 62

Oak Ridge, TN 37831

(615) 576-8401

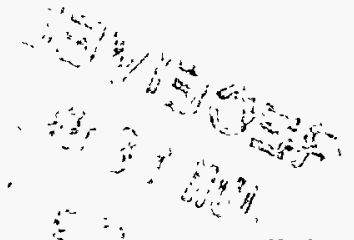

This report is publicly available from:

National Technical Information Service

Department of Commerce

5285 Port Royal Road

Springfield, VA 22161

(703) 487-4650 


\title{
BASELINE RISK ASSESSMENT OF GROUND WATER CONTAMINATION AT THE MONUMENT VALLEY URANIUM MILL TAILINGS SITE CANE VALLEY, ARIZONA
}

\author{
March 1996
}

Work performed under DOE Contract No. DE-AC04-91AL62350

\author{
Prepared for \\ U.S. Department of Energy \\ Grand Junction Projects Office \\ Prepared by \\ Jacobs Engineering Group Inc. \\ Albuquerque, New Mexico
}

\section{DISCLAIMER}

\begin{abstract}
This report was prepared as an account of work sponsored by an agency of the United States Government. Neither the United States Government nor any agency thereof, nor any of their employees, makes any warranty, express or implied, or assumes any legal liability or responsibility for the accuracy, completeness, or usefulness of any information, apparatus, product, or process disclosed, or represents that its use would not infringe privately owned rights. Reference herein to any specific commercial product, process, or service by trade name, trademark, manufacturer, or otherwise does not necessarily constitute or imply its endorsement, recommendation, or favoring by the United States Government or any agency thereof. The views and opinions of authors expressed herein do not necessarily state or reflect those of the United States Government or any agency thereof.
\end{abstract}





\section{CITIZENS' SUMMARY}

The U.S. Department of Energy (DOE) Uranium Mill Tailings Remedial Action (UMTRA) Project consists of the Surface Project (Phase I) and the Ground Water Project (Phase II). Under the UMTRA Surface Project, tailings, radioactive contaminated soil, equipment, and materials associated with the former uranium ore processing at UMTRA Project sites are placed into disposal cells. The cells are designed to reduce radon and other radiation emissions and to minimize further contamination of ground water. Surface cleanup at the Monument Valley UMTRA Project site near Cane Valley, Arizona, was completed in 1994. The Ground Water Project evaluates the nature and extent of ground water contamination that resulted from the uranium ore processing activities. The Ground Water Project is in its beginning stages.

Human health may be at risk from exposure to ground water contaminated by uranium ore processing. Exposure could occur by drinking water pumped out of a hypothetical well drilled in the contaminated areas. Adverse ecological and agricultural effects may also result from exposure to contaminated ground water. For example, livestock should not be watered with contaminated ground water.

A risk assessment describes a source of contamination, how that contamination reaches people and the environment, the amount of contamination to which people or the ecological environment may be exposed, and the health or ecological effects that could result from that exposure. This risk assessment is a site-specific document that will be used to evaluate current and potential future impacts to the public and the environment from exposure to contaminated ground water. The results of this evaluation and further site investigations will be used to determine a compliance strategy to comply with the UMTRA ground water standards.

\section{RISK SUMMARY}

In the area of the Monument Valley site, the Navajo people use ground water as the sole source of water for domestic and agricultural purposes. Access to the ground water is not restricted. However, no current users of the shallow site-related contaminated ground water for domestic and agricultural purposes have been identified. Since people are not exposed there is no risk to human health. This situation will continue if land and water use at the site does not change. It should be noted, however, that several plant species have been identified in the vicinity of the site that are used by the Navajo people as a cultural resource. The potential for adverse health effects to occur from these uses is not evaluated in this document.

This risk assessment evaluates possible future health problems associated with exposure to site-related contaminated ground water; the results indicate some health problems could occur if contaminated ground water were used as drinking water. Consequently, it is recommended that the site-related contaminated ground water should not be used as drinking water.

Potential impacts of site-related contaminated ground water on agricultural resources indicate that the contaminated shallow ground water would not be a suitable source of drinking water for livestock and there could also be negative impacts on plants irrigated with the contaminated ground water. Additionally, if a pond was created in the future, the contaminated ground water would not be suitable for aquatic life to inhabit. Some native plants growing above the contaminated ground water could have root systems deep enough to potentially access 
contaminated ground water. However, little is known as to whether or not they are accessing the water and to what extent, if at all, constituents from the contaminated ground water are bioaccumulating in the plant tissue.

\section{GROUND WATER QUALITY AND USES}

\section{Background ground water quality}

Background ground water quality is the natural quality of ground water if uranium milling activities had not taken place. Background ground water is generally a sodium-bicarbonate type with low total dissolved solids (TDS) and a low sulfate to chloride ratio.

\section{Site-related ground water quality}

Ground water was sampled in three ground water bearing units (aquifers) in the immediate vicinity of the Monument Valley site: the alluvial aquifer, the Shinarump Conglomerate, and the De Chelly Formation. Contaminated ground water (the plume) occurs primarily in the alluvial aquifer in areas west of Cane Valley Wash and north (the direction of ground water flow) of the former processing site.

The contaminated alluvial ground water has high TDS levels in comparison to background levels. It is a calcium-sulfate type with varying amounts of nitrate and ammonia and a high sulfate to chloride ratio. Constituents that exceed background levels in the alluvial aquifer are ammonium, calcium, chloride, iron, magnesium, manganese, nitrate, potassium, sodium, strontium, sulfate, uranium, and vanadium. The highest uranium concentration detected is in well 619 , a De Chelly Formation well. Based on the current knowledge of the site, contaminated ground water is not discharging to the surface.

\section{Private well ground water quality and use}

Several residences (one occasional and six year-round residences) are located to the south and southeast of the site. Ground water is the sole source of water for the Navajo people in this area. It is used for domestic and agricultural purposes.

One of the private wells (DOE identification 640), located to the south of the site, is contaminated, but the source of the constituents, e.g., sulfate and uranium, is unknown. The well is located in the opposite direction of the flow of the plume, and nitrate, a good indicator of site contamination, is not detected above background. Therefore, this well is believed not to be affected by the contaminant plume.

\section{HUMAN HEALTH RISK ASSESSMENT}

\section{Methods}

This risk assessment first identifies constituents that are present in ground water because of past uranium ore processing activities. This is done by comparing water quality data from wells drilled on the site or downgradient of the site to water quality data from background wells. Constituents detected in the most contaminated alluvial ground water at levels that could potentially cause adverse human health effects are called constituents of potential concern. 
Manganese, nitrate, strontium, sulfate, uranium, and vanadium are the constituents of potential concern for the alluvial aquifer at the Monument Valley site.

Next, this risk assessment examines potential human health problems that could be caused by exposure to constituents of potential concern. In a future scenario, a person in the Monument Valley site area could be exposed to contaminated ground water by drinking or bathing in ground water, eating meat or drinking milk from livestock watered with contaminated ground water, or eating produce irrigated with contaminated ground water. However, exposure to livestock products was not evaluated because livestock would not be able to survive the chronic use of the contaminated ground water. Ingestion of garden produce was not evaluated because of the limited information available concerning constituent uptake and bioaccumulation by plants. Several plant species have been identified in the vicinity of the site that are used by the Navajo people as a cultural resource. People could be exposed if the roots of any of the plants used access the contaminated ground water and bioaccumulate site-related constituents at levels that could be harmful if ingested or inhaled. However, because no site-specific plant uptake data are available and there is limited literature containing plant uptake data, the potential risks due to the ingestion (e.g., teas, medicines) or inhalation (burning) of plants are not evaluated in this risk assessment. Drinking the contaminated ground water is evaluated in detail.

Health risks are evaluated for the age group most likely to experience health problems from drinking contaminated ground water. Children (ages 1 to 10 years) are most likely to be affected by drinking contaminated ground water because they are small and they tend to drink more water compared to their body weight than adults and consequently take in a higher constituent dose than adults. Infants (aged 0 to 1 year) are especially sensitive to sulfate and nitrate. Cancer risks are evaluated for adults $(11+$ years), assuming a full lifetime of drinking the most contaminated ground water at the site.

The seriousness of health effects varies for several reasons. The levels of constituents in ground water can vary over time. Also, people vary in body weight, the amounts of water they drink each day, and their reactions to chemical exposures. This risk assessment considers these differences whenever possible.

This risk assessment provides graphs showing the various exposure levels that might occur and the most current scientific information on the health effects that could result from this hypothetical exposure.

\section{Results}

Some adverse human health risks would be expected to occur if the contaminated ground water is used as drinking water in the future. Note that only people who drink all their water from a well placed in the most contaminated part of the ground water could experience the health problems discussed in this section. Therefore, these results present the upper limit of possible risks.

Severe health effects could develop due to the alluvial plume water's nitrate and sulfate content. Following short-term exposure to nitrate, the majority of infants would experience severe toxicity; e.g., methemoglobinemia. Sulfate would also affect infants in particular by causing severe diarrhea. Manganese exposure could cause memory loss, irritability, and 
muscle rigidity in children. Noncarcinogenic adverse health effects would not be expected form exposure to strontium, uranium, and vanadium. The estimated cancer risk calculated for uranium ( 2 increased chances in a population of 100,000 of developing cancer) did not exceed the National Contingency Plan's upper-bound guideline of 1 increased chance in a population of 10,000 of developing cancer. For De Chelly monitor well 619 , the estimated lifetime cancer risk for uranium is $1 \times 10^{-4}$ ( 1 increased chance of developing cancer in a population of 10,000). This value falls at the upper-bound National Contingency Plan's guideline of $1 \times 10^{-4}$.

The exposure doses from the skin contact with ground water while bathing would not be expected to cause adverse health effects if they are the only source of exposure. These exposures would not alter the interpretation of this risk assessment if the doses were added to the drinking water ingestion doses.

\section{Private well 640 results}

Sulfate and uranium were evaluated for potential adverse health effects in the private well 640 . Sulfate exposure could cause mild diarrhea in infants. No noncarcinogenic adverse effects would be expected form uranium exposure. The estimated cancer risk calculated for uranium ( 2 increased chances in a population of 100,000 of developing cancer) did not exceed the National Contingency Plan's upper-bound guideline of 1 increased chance in a population of 10,000 of developing cancer.

\section{ECOLOGICAL ASSESSMENT}

\section{Methods}

The ecological risk assessment presented in this document is a screening level evaluation. This assessment identifies habitats and ecological receptors that could potentially be affected by contaminated ground water.

The field of ecological risk assessment has many uncertainties and limitations including limited data from media or interest; limited information on how some contaminants affect plants, animals, and aquatic life; and the inherent complexities of the ecosystem. In addition, methods of predicting nonchemical stresses (for example, drought), biologic interactions, behavior patterns, biological variability (differences in physical conditions, nutrient availability), and resiliency and recovery capacities are often unavailable. Therefore, it is often difficult to determine if contaminants can affect the biological component of an ecosystem and to predict whether observed effects will adversely affect the ecosystem.

The hydrogeological and geochemical evaluation of the site has determined that ground water is not discharging to the surface. Therefore, surface water and sediment are not evaluated for potential ecologic and environmental effects. For ground water, the entire list of constituents detected above background is evaluated for ecological and agricultural effects (ammonium, calcium, chloride, iron, magnesium, manganese, nitrate, potassium, sodium, strontium, sulfate, uranium, and vanadium). These constituents were compared to guideline values that are protective of aquatic life, livestock, plants, and wildlife. It should be noted that not all of the constituents of potential concern have guidelines and therefore could not be evaluated. 


\section{RESULTS}

Terrestrial plants were evaluated for potential current exposure to contaminated ground water. The depth to ground water is less than $30 \mathrm{ft}(9 \mathrm{~m})$ in some areas north of the site, and some deep rooted plants (e.g., black greasewood) have the potential to access the contaminated ground water. However, comparison of site levels of constituents of potential concern to available screening benchmarks for terrestrial plants (iron, manganese, uranium, and vanadium) showed none of these constituents exceeded the benchmarks. This indicates that for the plants that may access the plume, toxic effects would not be expected from exposure to these four constituents.

Additionally, hypothetical future scenarios of using the contaminated ground water to irrigate plants, water livestock or wildlife, or provide a habitat for aquatic life, were assessed.

The constituents of potential concern that have irrigation guidelines protective of plants are iron, manganese, TDS, and vanadium. If the contaminated ground water were used as a continuous source of irrigation water, high TDS could cause adverse effects to plants. Also, because of the salt content in the plume, chronic use of the ground water to irrigate crops could elicit a physiological drought condition in the plants.

Watering livestock from the most contaminated wells in the plume would not be acceptable due to elevated nitrate and sulfate concentrations. Nitrate exposure would result in the development of methemoglobinemia in ruminants (e.g., cattle). Sulfate exposure would cause severe diarrhea. Other potential adverse health effects to animals from exposure to sulfate concentrations could include weight loss, sulfhemoglobinemia, coordination loss, convulsions, and death.

Comparison of site levels of constituents of potential concern to available screening benchmarks for terrestrial animals (manganese, strontium, uranium, and vanadium) indicate that terrestrial wildlife would not be expected to experience any adverse effects from these four constituents if this water was ingested. If the ground water was used to create a pond, aquatic life would be likely to be adversely affected.

\section{CONCLUSIONS}

Currently, no users of the site-related contaminated ground water (for domestic or agricultural purposes) at the Monument Valley site have been identified. Therefore, people are not exposed to site-related contaminated ground water and human health is not at risk from these uses. This situation will continue if land and water use at the site does not change. It should be noted that several plant species have been identified in the vicinity of the site that are used by the Navajo people as a cultural resource. The potential for adverse toxic effects to occur from using these plants is not evaluated in this risk assessment.

If the site-related contaminated ground water is used for drinking water in the future, some health problems could occur. Consequently, it is recommended that the contaminated ground water not be used as drinking water. Furthermore, use of the contaminated ground water for a livestock pond is not recommended. This risk assessment is a conservative estimate of potential future risks at the Monument Valley site, because data from the most contaminated wells on the sites were used in this evaluation. Furthermore, the source of the contamination 
(tailings) has been removed, and contaminated ground water at the site will tend to disperse and dilute (move away from the site and decrease in concentration) thereby reducing potential exposure concentrations over time.

Changes in land and water uses may or may not create future risks. When specific uses are determined, they should be evaluated to identify any potential human health or ecological risks that could occur because of exposure to site-related contaminated ground water. 


\section{TABLE OF CONTENTS}

\section{Section}

1.0 INTRODUCTION .............................................................................................................

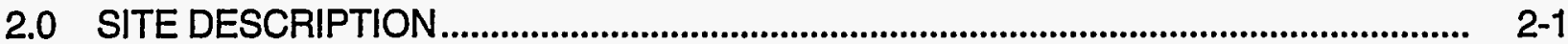

2.1 Site Background...................................................................................................... 2-1

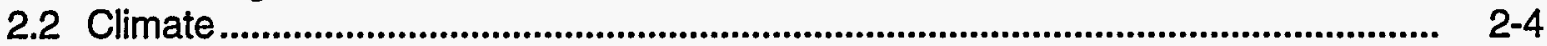

2.3 Geology And Hydrology ............................................................................................. 2-4

2.3.1 Physical setting ..................................................................................... 2-5

2.3.2 Ground water hydrology..................................................................... 2-5

2.3.3 Surface water hydrology ....................................................................... 2-17

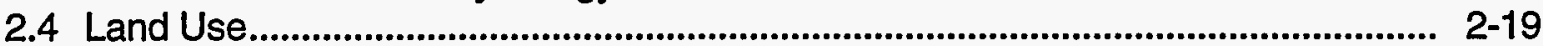

2.5 Water Use ......................................................................................................... 2-19

3.0 EXTENT OF CONTAMINATION.............................................................................. $3-1$

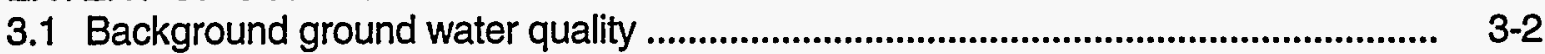

3.1.1 Alluvial aquifer.......................................................................................... $\quad 3-2$

3.1.2 Shinarump Conglomerate aquifer ............................................................... $\quad 3-5$

3.1.3 De Chelly Sandstone aquifer......................................................................... $\quad 3-5$

3.2 Nature and extent of contamination ........................................................................... $\quad 3-5$

3.2.1 Sources of ground water contamination ......................................................... $3-5$

3.2.2 Ground water contamination in the alluvial aquifer ....................................... 3-10

3.2.3 Ground water contamination in the Shinarump Conglomerate aquifer.

3.2.4 Ground water contamination in the De Chelly Sandstone aquifer............... 3-20

3.3 Constituents of potential concern............................................................................. 3-20

3.4 Contaminant fate and transport .................................................................................... 3-33

3.5 Surface water and sediment monitoring ....................................................................... $3-33$

3.5.1 Sediment results .......................................................................................... $3-35$

3.5.2 Surface water results ............................................................................... $3-35$

3.6 Summary.............................................................................................................. $3-41$

4.0 EXPOSURE ASSESSMENT .................................................................................... 4-1

4.1 Potentially exposed populations and exposure pathways ........................................ 4-1

4.1.1 Drinking water ingestion.............................................................................. 4-1

4.1.2 Dermal absorption.................................................................................... 4-3

4.1.3 Ingestion of ground.water-irrigated produce ............................................... 4-3

4.1.4 Ingestion of meat or milk from ground water-fed livestock.............................. 4-3

4.2 Exposure concentrations............................................................................................ 4-5

4.3 Estimation of intake.................................................................................... 4-5

4.4 Exposure assessment uncertainties ....................................................................... 4-15

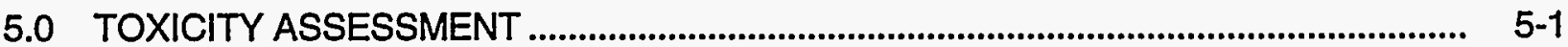

5.1 Toxicity values............................................................................................. 5

5.2 Contaminant toxicity summaries ................................................................. $5-3$ 


\section{TABLE OF CONTENTS (Concluded)}

\section{Section}

Page

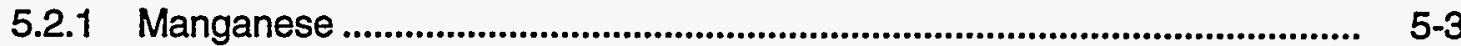

5.2.2 Nitrate......................................................................................................... $\quad 5-7$

5.2.3 Strontium.............................................................................................. $5-10$

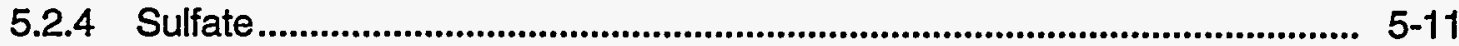

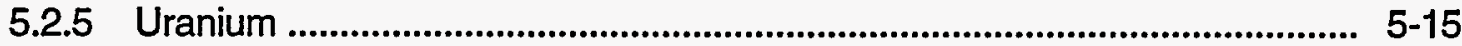

5.2.6 Vanadium ..................................................................................................... $5-17$

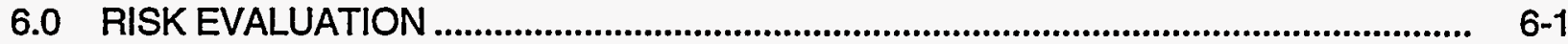

6.1 Potential noncarcinogenic health effects................................................................... $6-1$

6.2 Potential carcinogenic health effects.......................................................................... 6-4

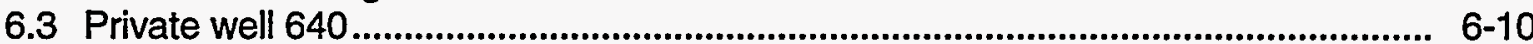

6.4 Limitations of risk evaluation ......................................................................................... 6-10

7.0 LIVESTOCK AND ENVIRONMENTAL EVALUATION .................................................. 7-1

7.1 Exposure pathways and receptors................................................................. $\quad 7-1$

7.2 Site vicinity plant wildlife characterization............................................................... $\quad 7-1$

7.3 Constituents of potential concern..................................................................... $\quad 7-2$

7.4 Potential impact on plants ...................................................................................... $\quad$ 7-3

7.4.1 Native plants ................................................................................. $\quad 7-3$

7.4.2 Produce.......................................................................................... $7-5$

7.5 Potential impact to aquatic and terrestrial wildlife .................................................... $\quad 7-5$

7.6 Potential impact on livestock............................................................................ $\quad 7-6$

7.7 Limitations of the ecological risk assessment ......................................................... $\quad$ 7-6

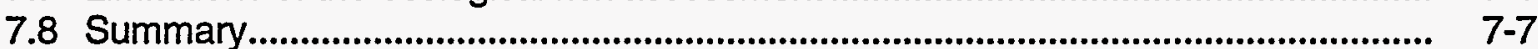

8.0 INTERPRETATION AND RECOMMENDATIONS ........................................................... 8- 8-1

8.1 Risk summary ........................................................................................ 8-1

8.1.1 Human health......................................................................................................... 8

8.1.2 Environmental and agricultural.............................................................. 8-2

8.2 Limitations of this risk assessment..................................................................... 8 8-3

8.3 Ground water standards ....................................................................................... 8-4

8.4 Risk mitigation measures ............................................................................... 8 8-6

8.5 Recommendations ...................................................................................................... $8-7$

9.0 LIST OF CONTRIBUTORS ......................................................................................... $9-1$

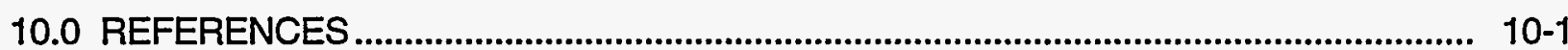




\section{LIST OF FIGURES}

\section{Figure}

Page

2.1 Site location map, Monument Valley, Arizona, site ...................................................... 2-2

2.2 Former mill operating area and tailings piles, Monument Valley, Arizona, site......... 2-3

2.3 Conceptualized east-west geologic cross section through the area of the Monument Valley, Arizona, site

2.4 Monitor well and surface water and sediment sampling locations, Monument Valley, Arizona, site

2.5 Alluvial water table contours, 7-8 December 1994, Monument Valley, Arizona, site

2.6 Shinarump Conglomerate piezometric surface, 7-8 December 1994, Monument Valley, Arizona, site

2.7 De Chelly piezometric surface, 7-8 December 1994, Monument Valley, Arizona, site

3.1 Distribution of sulfate in the alluvial aquifer, Monument Valley, Arizona, site

3.2 Distribution of nitrate in the alluvial aquifer, Monument Valley, Arizona, site

3.3 Distribution of uranium in the alluvial aquifer, Monument Valley, Arizona, site

3.4 Comparison of sulfate to chloride in the contaminated ground water (wells 606 and 655) and in naturally saline ground water (wells 605 and 640), alluvial aquifer, Monument Valley, Arizona, site.

3.5 Distribution of sufate to chloride ratios in the alluvial aquifer and surface waters, Monument Valley, Arizona, site.

3.6 Sulfate to chloride ratios in the surface water in the frog ponds (location 623) and Cane Valley Wash (locations 624 and 627), Monument Valley, Arizona, site

4.1 Conceptual model of exposure to contaminated ground water, Monument Valley, Arizona, site

4.2 Simulated distribution of nitrate based on data from well 606 , Monument Valley UMTRA Project site.

4.3 Simulated distribution of sulfate based on data from well 655, Monument Valley UMTRA Project site.

4.4 Simulated distribution of strontium based on data from well 655, Monument Valley UMTRA Project site.

4.5 Simulated distribution of uranium based on data from well 655, Monument Valley UMTRA Project site.

4.6 Simulated distribution of vanadium based on data from well 655 , Monument Valley UMTRA Project site.

4.7 Simulated distribution of manganese based on data from well 655, Monument Valley UMTRA Project site.

4.8 Probability distributions for tap water ingestion rates by age group

4.9 Body weight probability distributions by age group

4.10 Comparison of distributions of potential sulfate exposures as a result of drinking contaminated ground water for the three age groups examined, Monument Valley UMTRA Project site. 


\section{LIST OF FIGURES (Concluded)}

\section{Fiqure}

4.11 Distribution of potential nitrate exposures for infants consuming

contaminated ground water, Monument Valley UMTRA Project site

4.12 Distribution of potential strontium exposures for children as a result of

contaminated ground water ingestion, Monument Valley UMTRA Project site.

4.13 Distribution of potential uranium exposures for children as a result of contaminated ground water ingestion, Monument Valley UMTRA

Project site

4.14 Distribution of potential vanadium exposures for children as a result of contaminated ground water ingestion, Monument Valley UMTRA

Project site

4.15 Distribution of potential manganese exposures for children as a result of contaminated ground water ingestion, Monument Valley UMTRA

Project site

5.1 Manganese toxicity ranges.

5.2 Nitrate toxicity ranges for infants

5.3 Strontium toxicity ranges

5.4 Sulfate toxicity ranges

5-14

5.5 Half-lives and radiation emission patterns resulting from decay of uranium-238.

5.6 Uranium toxicity ranges

5.7 Vanadium toxicity ranges

6.1 Health effects of predicted nitrate exposure ranges for infants, Monument Valley, Arizona, site

6.2 Health effects of predicted sulfate exposure ranges for infants, Monument Valley, Arizona, site

6.3 Health effects of predicted manganese exposure ranges for infants, Monument Valley, Arizona, site

6.4 Health effects of predicted strontium exposure ranges for infants, Monument Valley, Arizona, site

6.5 Health effects of predicted vanadium exposure ranges for infants, Monument Valley, Arizona, site

6.6 Health effects of predicted uranium exposure ranges for children, Monument Valley, Arizona, site

6.7 Increased lifetime cancer risk associated with predicted radiation exposures resulting from ingestion of uranium in ground water, Monument Valley, Arizona, site 


\section{LIST OF TABLES}

Table

Page

2.1 Ground water monitor well network at Monument Valley, Arizona, site

2.2 Summary of hydrologic properties of the geologic units, Monument Valley, Arizona, site

3.1 Background ground water quality in the alluvial aquifer, Monument Valley,

Arizona, site

3.2 Background ground water quality in the Shinarump Conglomerate and

De Chelly Sandstone aquifers, Monument Valley, Arizona, site

3.3

Chemistry of tailings solutions and leachates, Monument Valley, Arizona, site

3.4

Comparison of contaminated ground water to tailings solution and

background ground water quality data in the alluvial aquifer, Monument

Valley, Arizona, site

3.5 Comparison of contaminated ground water to background ground water

quality data in the Shinarump Conglomerate aquifer, Monument Valley,

Arizona, site

3.6 Comparison of contaminated ground water to background ground water quality data in the De Chelly Sandstone aquifer, Monument Valley,

Arizona, site

3.7 Statistical summary of ground water quality in the alluvial aquifer at Monument Valley, April 1988 - February 1993

3.8 Constituents of potential concern for human health evaluation. $3-32$

3.9 Speciation summary, Monument Valley, Arizona, site 3-34

3.10 Summary of sediment chemistry data, Monument Valley, Arizona, site.

3.11 Summary of surface water quality data, Monument Valley, Arizona, site

4.1 Exposure dose calculations for ground water ingestion and dermal contact, Monument Valley, Arizona, site

5.1 Toxicity values: potential noncarcinogenic effects

5.2 Toxicity values: carcinogenic effects

7.1 Comparison of constituents of potential concern in ground water with available water quality values

8.1 Maximum concentration limits and health advisories of constituents 


\section{LIST OF ACRONYMS}

\section{Acronym}

\section{BIA}

DHHS

DOE

EPA

FWQC

FWS

HEAST

IHS

IRIS

$\mathrm{LD}_{50}$

LOAEL

$\mathrm{MCL}$

$\mathrm{MDL}$

NCP

NEPA

NOAEL

PEIS

RfD

RRM

SAR

SF

TDS

UCL

UMTRA

UMTRCA

USGS

\section{Definition}

Bureau of Indian Affairs

Department of Health and Human Services

U.S. Department of Energy

U.S. Environmental Protection Agency

Federal Water Quality Criteria

Fish and Wildlife Service

Health Effects Assessment Summary Tables

Indian Health Service

Integrated Risk Information System

lethal dose for 50 percent of sample

lowest-observed-adverse-effect level

maximum concentration limit

method detection limit

National Contingency Plan

National Environmental Policy Act

no-observed-adverse-effect level

programmatic environmental impact statement

reference dose

residual radioactive material

sodium adsorption ratio

slope factor

total dissolved solids

upper confidence limit

Uranium Mill Tailings Remedial Action

Uranium Mill Tailings Radiation Control Act

U.S. Geological Survey 


\subsection{INTRODUCTION}

The purpose of this baseline risk assessment is to determine if ground water contamination at the former uranium mill processing site near Monument Valley, Arizona, could adversely affect public health or the environment. The Monument Valley site is one of 24 abandoned uranium processing sites that are undergoing remediation in accordance with the requirements of the Uranium Mill Tailings Radiation Control Act (UMTRCA) of 1978 (42 USC $\$ 7901$ et seq.) under the oversight of the U.S. Department of Energy (DOE) Uranium Mill Tailings Remedial Action (UMTRA) Project. The 1988 amendments to the UMTRCA authorize the DOE to conduct ground water restoration activities. Under the UMTRA Ground Water Project, site-related ground water contamination is being evaluated and an appropriate ground water compliance strategy will be selected. Results of this risk assessment will be considered in developing a ground water compliance strategy for the Monument Valley site.

Under the UMTRA Surface Project, the source of ground water contamination, residual radioactive material (RRM), was stabilized in the Mexican Hat, Utah, disposal cell. The disposal cell was engineered to prevent radon and other radiation emissions and to prevent ground water contamination. Surface remedial action at the Monument Valley site was completed in January 1994.

The programmatic environmental impact statement (PEIS) for the UMTRA Ground Water Project (DOE, 1996a) proposes a framework for selecting a ground water compliance strategy to meet the U.S. Environmental Protection Agency (EPA) ground water standards for the UMTRA Project (40 CFR Part 192). This baseline risk assessment evaluates potential current and future human health and environmental risks from ground water contamination at the Monument Valley site and provides information to help determine an appropriate ground water compliance strategy. Remaining data gaps in ground water characterization will be addressed in the Monument Valley site observational work plan. Based on the PEIS, the site observational work plan, and this risk assessment, site-specific National Environmental Policy Act (NEPA) documentation will be prepared to identify the impacts of the proposed ground water compliance strategy for the site.

This risk assessment is a baseline assessment in that it describes existing ground water conditions at the site. However, the ground water at the site and site vicinity has not been fully characterized with respect to nature and extent of contamination. This document identifies potential risks that may need attention before the site is fully characterized.

This baseline risk assessment follows the basic framework outlined by the EPA for evaluating hazardous waste sites (EPA, 1989). This assessment includes the following steps:

- Data evaluation.

- Combining existing data from various site investigations.

- Comparing sample results with background and tailings source data.

- Selecting chemical data for use in the risk assessment. 
- Exposure assessment.

- Characterizing exposure settings.

- Identifying exposure pathways.

- Quantifying the exposure.

- Toxicity assessment.

- Identifying toxicity values.

- Evaluating noncarcinogenic effects.

- Evaluating carcinogenic effects from radionuclides and chemical carcinogens.

- Public health risk characterization.

- Comparing toxicity ranges with predicted exposure ranges.

- Combining risks across exposure pathways and multiple constituents.

- Characterizing uncertainties.

- Environmental risk.

- Characterizing potential biota exposure pathways.

- Identifying the potential ecological receptors.

- Evaluating the environmental risk qualitatively.

This framework is incorporated into the methodology developed for the UMTRA Ground Water Project (DOE, 1996b). The methodology allows for the use of Monte Carlo analysis rather than a single exposure dose calculation to evaluate potential adverse human health effects from using the contaminated ground water at this site as drinking water. Risk interpretation is based on a comparison between the predicted exposure dose distribution and observed toxicity ranges of constituents of potential concern. Graphic presentations (figures) are designed to increase understanding of potential risks based on relative toxicity, likelihood of effect, and severity of effect.

The methodology used for the ecological portion of this risk assessment generally follows the EPA's Risk Assessment Guidance for Superfund (EPA, 1989). The ecological risk assessment at the Monument Valley site identifies potentially exposed habitats and receptors and qualitatively evaluates analytical data to describe how contamination could affect the ecological environment. Thus, this qualitative approach is a screening level assessment of the ecological risks associated with potential exposure to contaminated media at the site. 


\subsection{SITE DESCRIPTION}

The Monument Valley site is on the Navajo Reservation in northern Arizona (Figure 2.1). The site is accessed by Bureau of Indian Affairs (BIA) Navajo Service Road 6440, approximately 5 miles (mi) (8 kilometers [km]) south of the Arizona-Utah border and $14 \mathrm{mi}(23 \mathrm{~km})$ south of the Mexican Hat UMTRA Project disposal site. The Monument Valley site is not actually within Monument Valley, but in a remote area of Cane Valley. The mill operated from 1955 through 1968. The designated site boundary includes the former mill site, two former tailings pile areas, heap leaching pads, a former batch leaching area, and an evaporation pond (Figure 2.2).

\section{$2.1 \quad$ SITE BACKGROUND}

Mining in the Monument Valley site vicinity began in 1942 at Monument No. 2 Mine, approximately $1 \mathrm{mi}(1.6 \mathrm{~km})$ west of the site. Monument No. 2 Mine operated as a strip mine from 1942 through 1949 (Witkind and Thaden, 1963). Underground and strip mining were conducted from 1949 until the mill closed in 1968.

Before 1955, there was no mill at the site and all ore was trucked to uranium mills in Durango and Naturita, Colorado. Mill operations began at the Monument Valley site in 1955. From 1955 through 1964, the mill was a mechanical separator. In this operation, ore was crushed and sorted by grain size. The finer-grained material, which was higher in uranium content, was shipped off-site for chemical concentration at the Durango and Naturita, Colorado, mills (FBDU, 1981). No chemicals were used at the site other than minor amounts of flocculants. However, large amounts of water were used to separate the fine- and coarse-grained materials. The coarser-grained material remained on the site and was piled in the areas identified as former mill and old tailings (Figure 2.2). The water came from on-site wells drawing from the De Chelly Formation.

Phase II of the mill operation commenced in 1964 after installation of batch leaching equipment. This process continued for approximately 3 years, during which approximately $1,000,000$ tons $(900,000$ metric tons) of sandy tailings were processed (approximately 900 tons [ 800 metric tons] per day). A separate heap leaching operation was used on an additional 100,000 tons (90,000 metric tons) of low-grade ore (Merritt, 1971).

The mill buildings and milling equipment were removed sometime after 1968 when site processing operations ceased. Little or no site activity occurred until 1992, when removal of the tailings piles, windblown tailings, concrete foundations, and debris from the site began. These materials were placed in the UMTRA Project disposal cell located near Mexican Hat, Utah. The relocation of these materials was completed in January 1994. 
Figure 2.1

Site Location Map

Monument Valley, Arizona, Site

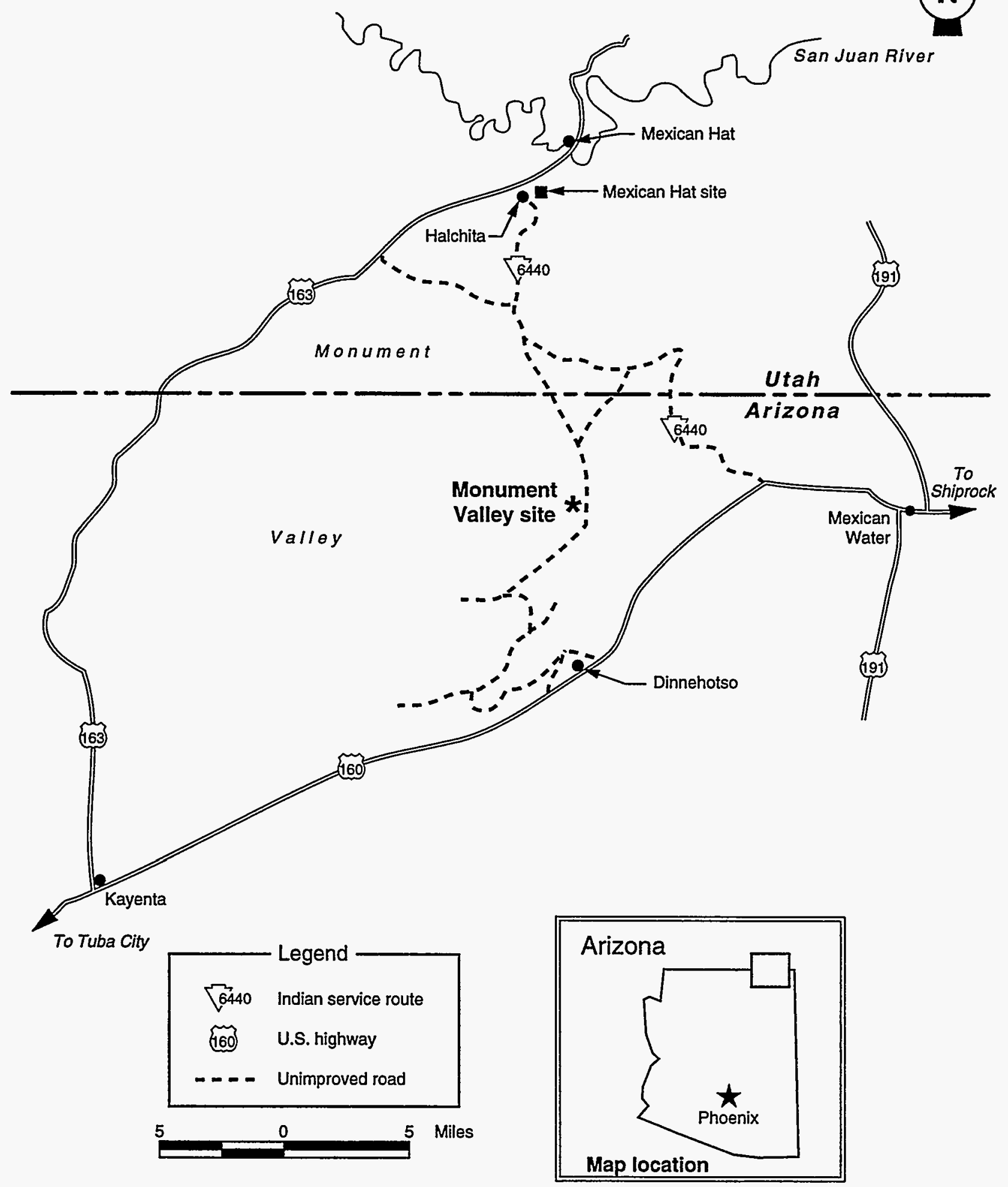

MAC STTEMONBLRASITELOC 
Figure 2.2

\section{Former Mill Operating Area and Tailings Piles, Monument Valley, Arizona, Site}

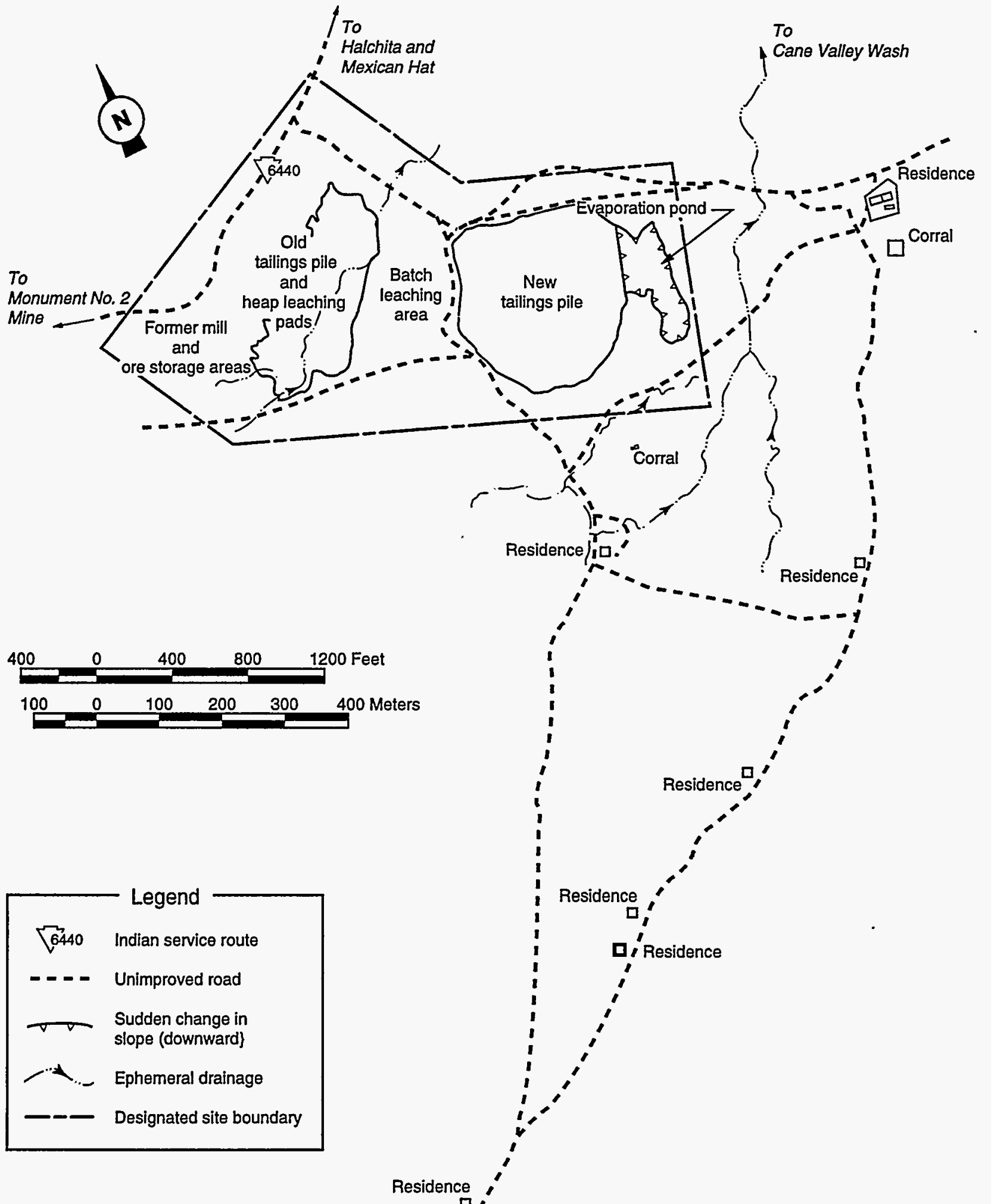


A vicinity property, approximately $1 \mathrm{mi}(1.6 \mathrm{~km})$ east of the processing site along Cane Valley Wash, was remediated during surface cleanup of the site. This property was the northern frog pond and sections of the old haul road north of the frog ponds; approximately 15,000 cubic yards (11,000 cubic meters) of contaminated materials were removed. The banks of the pond and low areas of the road had been stabilized by uranium mineralization rock during milling operations.

The mill site was leased from the Navajo Nation until 1968, when the mill closed and the lease expired. Control of the site, structures, and materials reverted to the Navajo Nation at that time (DOE, 1989).

\subsection{CLIMATE}

The site is located in an arid climate, receiving approximately 8 inches (20 centimeters [cm]) of annual precipitation. Annual snowfall ranges between 10 and 40 inches $(25$ and $100 \mathrm{~cm})$. The two driest months are generally May and June. Most precipitation usually occurs during two time periods: July through August and December through February (Cooley et al., 1969). Rainfall during the summer commonly occurs as high-intensity, short duration storms, which result in runoff. Precipitation during the winter, however, usually occurs during low-intensity, longerduration storms (Cooley et al., 1969).

The weather station closest to the Monument Valley site is in Mexican Hat, Utah, approximately $14 \mathrm{mi}(23 \mathrm{~km})$ north of the Monument Valley site. The DOE has summarized climatological data for the Mexican Hat weather station for the period 1951 through 1980 (DOE, 1993). The average annual pan evaporation rate is 84.4 inches $(214 \mathrm{~cm})$ at Mexican Hat. Pan evaporation rates exceed precipitation every month except January. The highest rates are from May through August, when pan evaporation exceeds 10 inches $(25 \mathrm{~cm})$ per month.

Temperatures show considerable variation within 24-hour periods and across seasons. Winters are cold, with overnight temperatures typically below freezing from November through March. Summers are hot, with highs from 90 degrees Fahrenheit $\left({ }^{\circ} \mathrm{F}\right)$ to the low 100 s (32 to 40 degrees Celsius $\left.\left[{ }^{\circ} \mathrm{C}\right]\right)$.

The potential for rainfall infiltration and recharge to the ground water system may be limited in the summer months due to the rainfall patterns, high evaporation rates, and evapotranspiration from plants. However, the rainfall pattern in the winter months, combined with lower evaporation rates and limited evapotranspiration from plants (due to the freezing temperatures), increases the potential for ground water recharge during those months.

\subsection{GEOLOGY AND HYDROLOGY}

A brief discussion of the site geology and hydrology follows. More detail is provided in the Remedial Action Plan for the Codisposal and Stabilization of the Monument Valley and Mexican Hat Uranium Mill Tailings at Mexican Hat, Utah (DOE, 1993) . Following some introductory information, the geology and hydrology of the hydrostratigraphic units of interest are summarized. 


\subsubsection{Physical setting}

The Monument Valley site is on the west side of Cane Valley, which drains to the north. The valley floor elevation is approximately 4800 feet $(\mathrm{ft})$ (1500 meters [m]) above the National Geodetic Vertical Datum of 1928 along Cane Valley Wash, east of the former tailings pile (Figure 2.3).

The valley is bordered on the east by Comb Ridge, a 600-ft (200-m)-high escarpment of Navajo, Kayenta, and Wingate sandstones. On the west side of the valley (where the tailings were located), the bedrock dips to the east at approximately 5 degrees and rises up to Yazzie Mesa at an elevation of over $5300 \mathrm{ft}$ (1600 m).

\subsubsection{Ground water hydrology}

The geologic formations of concern underlying the Monument Valley site are described by Witkind and Thaden (1963). In descending order, they include:

- Unconsolidated eolian (windblown) and alluvial deposits, hereafter referred to as the alluvial aquifer.

- Shinarump Member of the Chinle Formation, known as the Shinarump Conglomerate.

- Moenkopi Formation.

- De Chelly Sandstone of the Cutler Formation.

A conceptualized cross-section through the site which shows the general geology is presented in Figure 2.3.

Figure 2.4 shows monitor well locations at the site. Well logs prepared during monitor well installation were used to prepare the cross section. The geologic units were identified by comparing the descriptions of Witkind and Thaden (1963) to the lithologic descriptions on the well logs and observations of geologic outcrops at and near the site. Monitor well information is summarized in Table 2.1, and hydrologic properties of each geologic unit are summarized in Table 2.2.

\section{Alluvial aquifer}

\section{Geology}

The alluvial aquifer consists of fine- to medium-grained eolian sands and alluvial clays, silts, sands, gravels, and cobbles. Because the alluvial aquifer is derived in part from the nearby uranium-bearing rock units, it naturally contains uranium. 
Figure 2.3

Conceptualized East-West Geologic Cross Section Through the Area of the Monument Valley, Arizona, Site

แั่

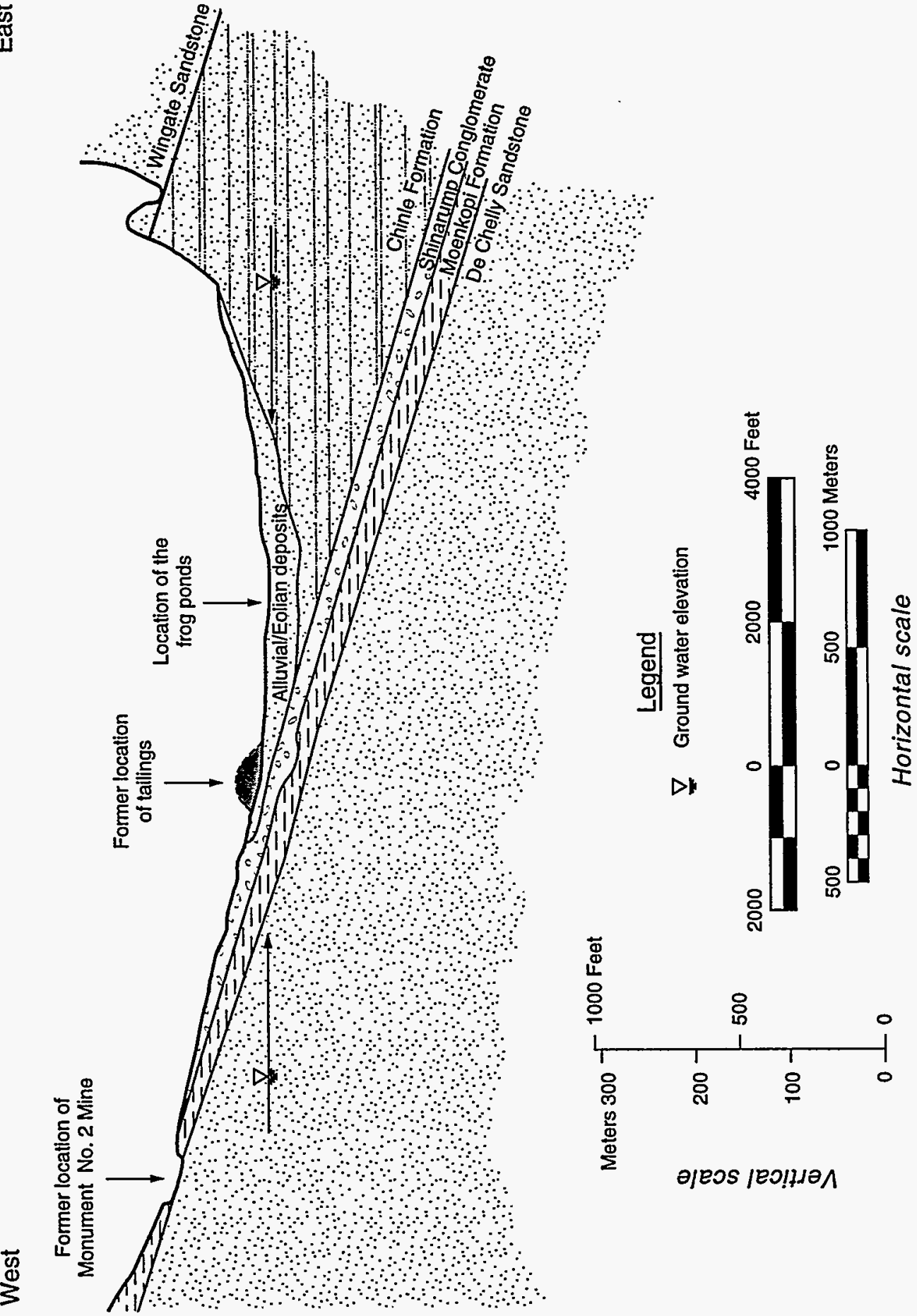

MAC: SITEMONBBLPAGEOXSEC 
Figure 2.4

Monitor Well and Surface Water and Sediment Sampling Locations

Monument Valley, Arizona, Site

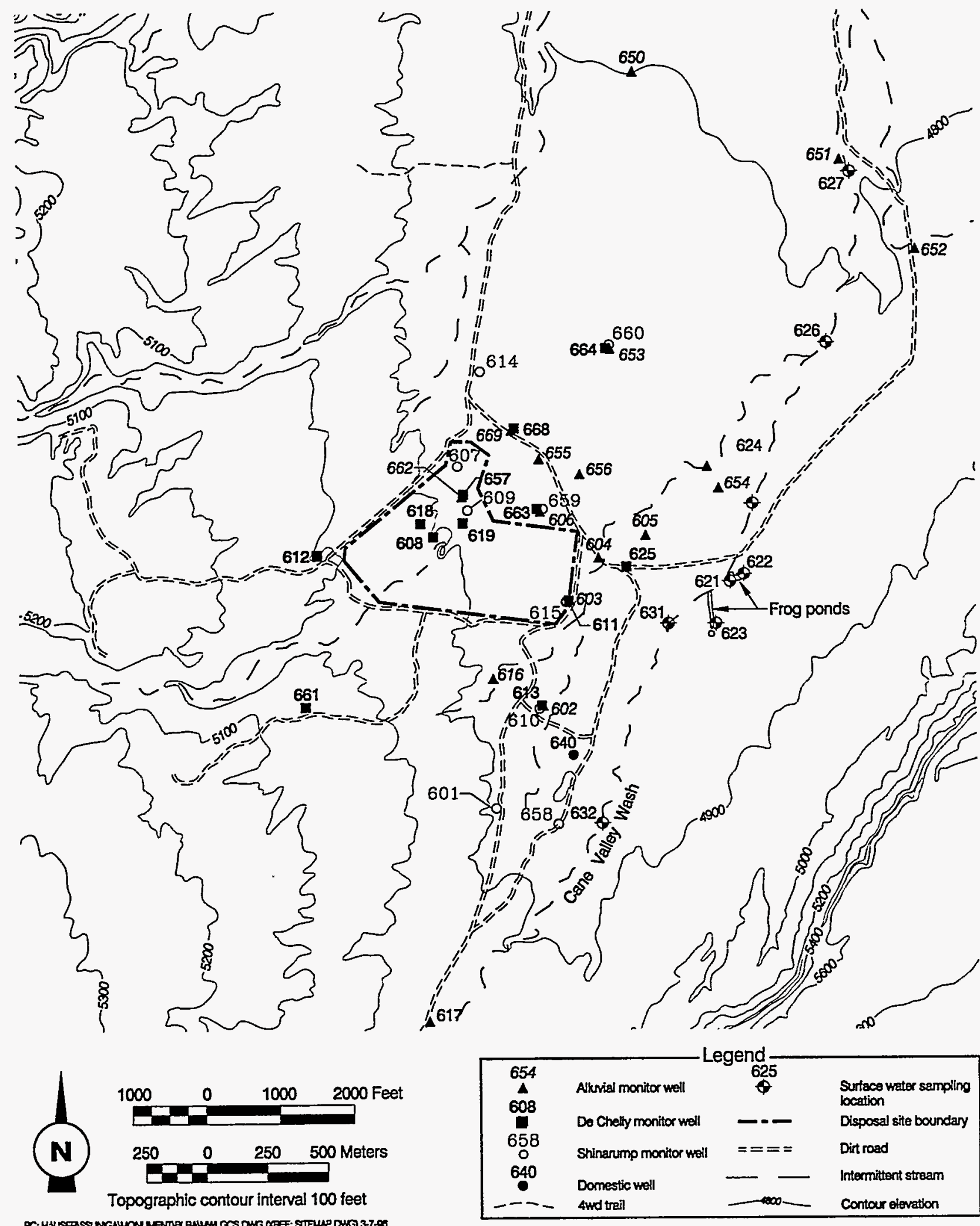

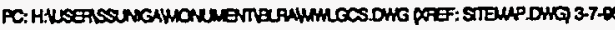


Table 2.1 Ground water monitor well network at Monument Valley, Arizona, site

\begin{tabular}{|c|c|c|c|c|c|}
\hline \multirow[b]{2}{*}{ Location ID } & \multicolumn{4}{|c|}{ Screened interval (depth below surface) } & \multirow{2}{*}{$\begin{array}{c}\text { No. samples } \\
\text { (1988 through 1994) }\end{array}$} \\
\hline & \multicolumn{2}{|c|}{ (ft) } & \multicolumn{2}{|c|}{ (m) } & \\
\hline \multicolumn{6}{|l|}{ Alluvial aquifer } \\
\hline \multicolumn{6}{|l|}{ Upgradient } \\
\hline MON-01-0602 & 33 & 53 & 10 & 16 & 7 \\
\hline MON-01-0616 & b & $b$ & $b$ & $b$ & 5 \\
\hline MON-01-0617 & $b$ & b & b & $b$ & 4 \\
\hline MON-01-0640 & $\mathrm{b}$ & b & $\mathbf{b}$ & b & 1 \\
\hline \multicolumn{6}{|l|}{ Crossgradient } \\
\hline MON-01-0603 & 33 & 53 & 10 & 16 & 6 \\
\hline MON-01-0604 & 13 & 28 & 4 & 8 & 6 \\
\hline MON-01-0605 & 14 & 29 & 4 & 9 & 8 \\
\hline MON-01-0654 & 57 & 77 & 17 & 23 & 9 \\
\hline \multicolumn{6}{|l|}{ Downgradient } \\
\hline MON-01-0606 ${ }^{c}$ & 32 & 42 & 10 & 13 & 9 \\
\hline MON-01-0650 & 78 & 98 & 24 & 30 & 2 \\
\hline MON-01-0651 & 20 & 80 & 6 & 24 & 9 \\
\hline MON-01-0652 & 34 & 54 & 10 & 16 & 5 \\
\hline MON-01-0653 & 56 & 76 & 17 & 23 & 9 \\
\hline MON-01-0655 & 38 & 58 & 12 & 18 & 10 \\
\hline MON-01-0656 & 38 & 58 & 12 & 18 & 3 \\
\hline MON-01-0662 & 35.5 & 67.5 & 11 & 20 & 5 \\
\hline MON-01-0669 & 34 & 54 & 10 & 16 & 2 \\
\hline \multicolumn{6}{|c|}{$\begin{array}{l}\text { Shinarump Conglomerate aquifer } \\
\text { Upgradient }\end{array}$} \\
\hline MON-01-0601 & 12 & 22 & 4 & 7 & 4 \\
\hline MON-01-0610 & 63 & 83 & 19 & 25 & 0 \\
\hline MON-01-0658 & 135 & 155 & 41 & 47 & 0 \\
\hline \multicolumn{6}{|l|}{ Crossgradient } \\
\hline MON-01-0615 & 68 & 88 & 21 & 27 & 2 \\
\hline \multicolumn{6}{|l|}{ Downgradient } \\
\hline MON-01-0607 & 12.5 & 22.5 & 4 & 7 & 0 \\
\hline MON-01-0609 & 7 & 12 & 2 & 4 & 0 \\
\hline MON-01-0614 & 48 & 68 & 15 & 21 & 8 \\
\hline MON-01-0659 & 87 & 107 & 27 & 33 & 9 \\
\hline MON-01-0660 & 133 & 153 & 41 & 47 & 6 \\
\hline
\end{tabular}


Table 2.1 Ground water monitor well network at Monument Valley, Arizona, site (Concluded)

\begin{tabular}{|c|c|c|c|c|c|}
\hline \multirow[b]{2}{*}{ Location ID } & \multicolumn{4}{|c|}{ Screened interval (depth below surface) } & \multirow{2}{*}{$\begin{array}{c}\text { No. samples } \\
\text { (1988 through 1994) }\end{array}$} \\
\hline & \multicolumn{2}{|c|}{$(\mathrm{ft})$} & \multicolumn{2}{|c|}{$(\mathrm{m})$} & \\
\hline \multicolumn{6}{|l|}{$\begin{array}{l}\text { De Chelly Sandstone } \\
\text { aquifer }\end{array}$} \\
\hline \multicolumn{6}{|l|}{ Upgradient } \\
\hline MON-01-0612 & 175 & 195 & 53 & 59 & 1 \\
\hline MON-01-0613 ${ }^{a}$ & 138 & 158 & 42 & 48 & 8 \\
\hline MON-01-0661 & 190 & 210 & 58 & 64 & 0 \\
\hline \multicolumn{6}{|l|}{ Crossgradient } \\
\hline MON-01-0611 & 163 & 183 & 50 & 56 & 1 \\
\hline MON-01-0625 & b & $b$ & $b$ & b & 3 \\
\hline \multicolumn{6}{|l|}{ Downgradient } \\
\hline MON-01-0608 & 98 & 118 & 30 & 36 & 0 \\
\hline MON-01-0618 & $b$ & $b$ & $b$ & $b$ & 0 \\
\hline MON-01-0619 & $b$ & $b$ & $b$ & b & 0 \\
\hline MON-01-0657 & 121 & 136 & 37 & 41 & 6 \\
\hline MON-01-0663 & 175 & 215 & 53 & 66 & 9 \\
\hline MON-01-0664 & 211 & 231 & 64 & 70 & 0 \\
\hline MON-01-0668 & 180 & 200 & 55 & 61 & 1 \\
\hline
\end{tabular}

${ }^{a}$ Wells used to establish background water quality for purposes of risk assessment.

bells are either domestic or production wells for which log data are not available. Based on water quality analysis, wells are assumed to be completed in the given aquifers.

'Wells with highest constituent concentrations used to estimate potential exposure doses in this risk assessment.

'Well 619 is an open borehole with no casing and therefore is likely to draw water from multiple aquifers. 


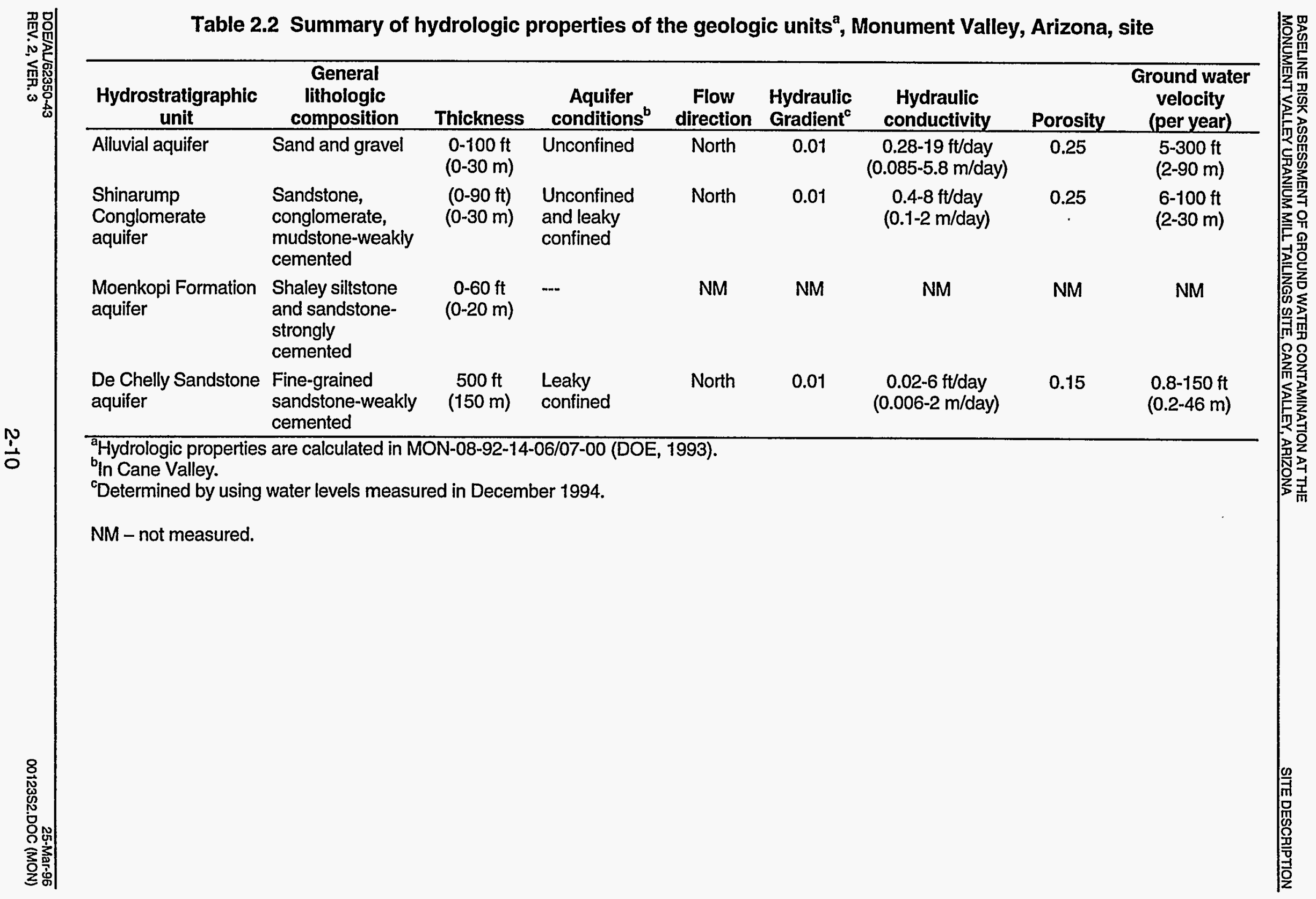


The alluvial aquifer is limited in areal extent and varies in thickness. The unit is more than $100 \mathrm{ft}(30 \mathrm{~m})$ thick in the center of Cane Valley, but thins toward each edge of the valley and is not present at the bedrock exposures along the eastern and western sides of the valley. The maximum observed thickness is $120 \mathrm{ft}[37 \mathrm{~m}]$ in the vicinity of alluvial well MON-01-0662, designated 662. (Note: All wells cited in this report include the prefix "MON-01-0." For ease of reading, this prefix is cited only in tables).

The alluvium lays unconformably over the Shinarump Conglomerate. Portions of the Shinarump are difficult to differentiate from the alluvium. Figure 2.5 shows the approximate extent of the alluvium in the site vicinity. The areal extent of the alluvium was estimated from aerial photographs of the site and from Witkind and Thaden (1963).

Site information, including well logs, aerial photographs, and field observations of the surficial geology and rock outcrops, strongly indicate there are buried channels covered by alluvial and windblown sands near the center of Cane Valley and under a portion of the site. For example, the alluvium is thickest in the vicinity of well 662, and neither the Shinarump Conglomerate nor Moenkopi Formation are present at that location.

The buried channels were created before or during the early periods of alluvial deposition and eroded through the Shinarump Conglomerate and portions (or, in some places, all) of the Moenkopi Formation. The channels result in thicker areas of the alluvium and a more direct hydraulic connection between the alluvial aquifer and the De Chelly Sandstone.

\section{Hydrology}

Ground water within the alluvial aquifer is unconfined. Depths to ground water range from the land surface near the center of Cane Valley Wash to slightly more than $30 \mathrm{ft}(10 \mathrm{~m})$ below grade near the site and the approximate center of Cane Valley. A ground water surface map, prepared from water levels taken in December 1994, is presented in Figure 2.5.

In the vicinity of the site, ground water generally flows north in the alluvial aquifer with some localized variations. For example, water-table contours near the frog ponds indicate that the area around the ponds acts as a recharge area to the alluvial aquifer. The ponds probably are fed by water from the De Chelly Sandstone, thus providing the source of recharge in that area. The alluvial aquifer and the De Chelly Sandstone are connected because the confining units between the De Chelly Sandstone and the alluvial aquifer are either thin or non-existent in the frog pond area. Because the potentiometric surface of the De Chelly Sandstone is at or above the elevation of the water table and land surface in that area, water will flow at the ground surface from the De Chelly Sandstone. Geochemical data supporting recharge of the alluvial aquifer from the De Chelly Sandstone are presented in Section 3.4. 


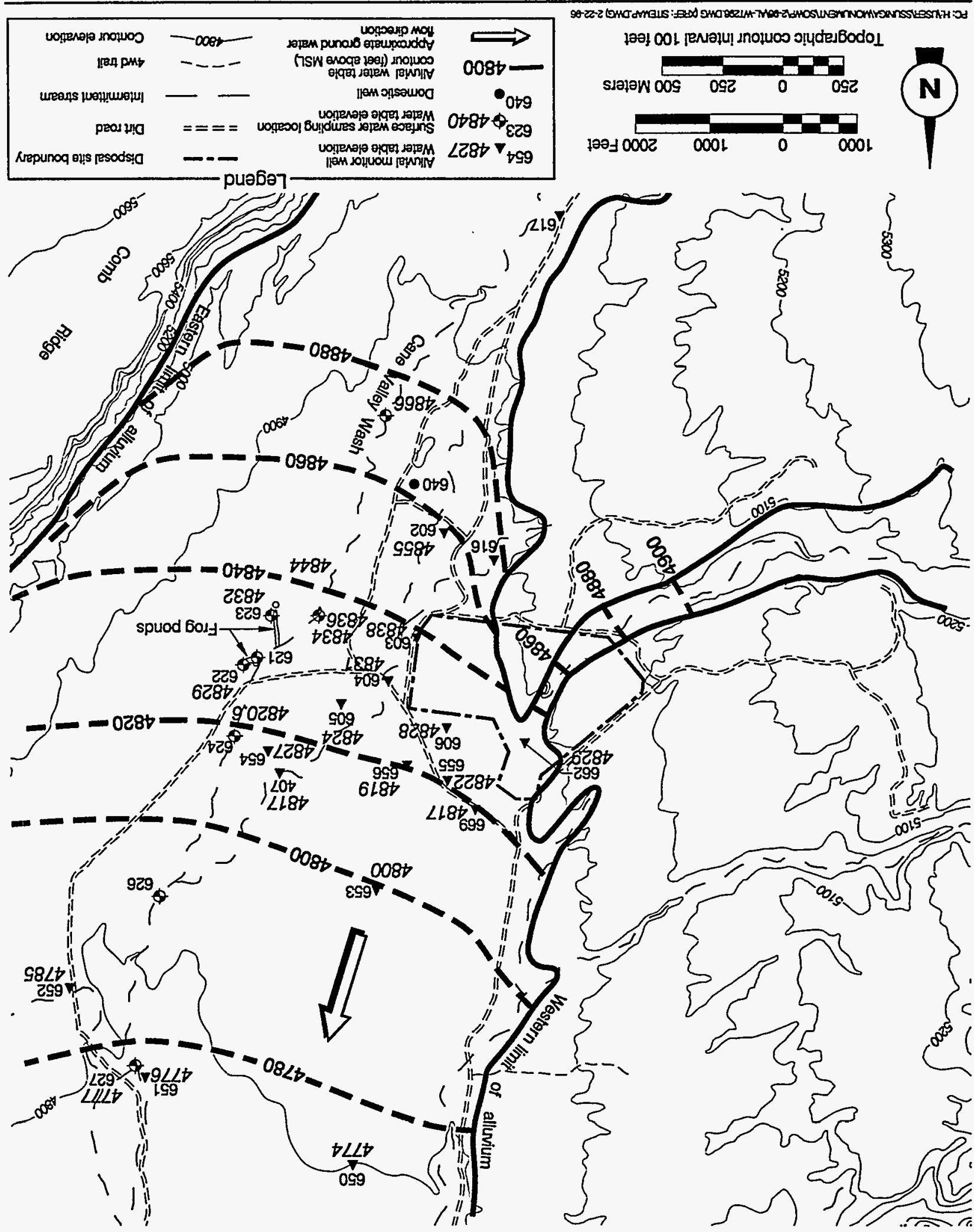

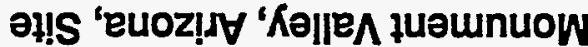

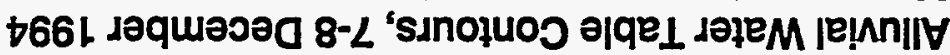


The hydraulic conductivity of the alluvial aquifer was estimated using slug and aquifer pumping tests. Analyses are reported in calculation set MON-08-92-1406/07-00 (DOE, 1993). Values ranged from 0.28 to $19 \mathrm{ft} /$ day $(0.085$ to $5.8 \mathrm{~m} /$ day $)$ as shown in Table 2.2 .

Water level measurements taken during December 1994 were used to estimate the hydraulic gradient in the alluvial aquifer at about 0.01 in the vicinity of the site (DOE, 1995). The porosity of the alluvial aquifer has not been measured. However, most of the aquifer materials are fine- to medium-grained sand and gravel. The total porosity of sand ranges from 0.25 to 0.50 and the total porosity of gravel ranges from 0.25 to 0.40 . Because the alluvial materials are poorly sorted (i.e., the aquifer materials are a wide range of grain sizes), the porosity of the alluvial aquifer likely is at the low end of the sand and gravel porosity ranges (Freeze and Cherry, 1979). For coarser grained soils, the effective porosity is usually about the same as the total porosity. Using an effective porosity of 0.25 will result in an estimated velocity of 5 to $300 \mathrm{ft} / \mathrm{yr}$. Over a 30 year period, constituents could move from 150 to $9000 \mathrm{ft}$ (46 to $2700 \mathrm{~m}$ ). This is consistent with water quality observations in wells that show the presence of sulfate at a distance of at least $3000 \mathrm{ft}(900 \mathrm{~m})$ but less than $6500 \mathrm{ft}$ $(2000 \mathrm{~m})$ from the site.

Recharge to the alluvial aquifer is from precipitation and from upward leakage from the aquifers below. Recharge is also provided by discharge from artesian monitor wells 611,613 , and 615 and former production well 625 , which are completed in the De Chelly Sandstone and occasionally flow at ground surface. As mentioned previously, recharge is likely to occur from the De Chelly Sandstone in the frog pond area.

Discharge from the alluvial aquifer is through evapotranspiration, evaporation where the water table is at or near land surface, and occasional discharges to Cane Valley Wash when and where the water table intersects the ground surface. Pumping from the alluvial aquifer is limited, accounting for very minor discharge compared to natural aquifer discharge. Pumping of the alluvial aquifer does not occur downgradient from the site.

\section{Shinarump Conglomerate}

\section{Geology}

The Shinarump Conglomerate is a heterogeneous combination of lenticular, cross-bedded formations of sandstone and conglomerate with occasional thin mudstone layers. Large quantities of fossil plant matter and silicified wood are associated with the coarser-grained materials. The coarser-grained materials (i.e., conglomerate) are generally at the base of the unit, grading upward into finergrained materials (i.e., sandstone and some mudstone). The most probable method of deposition for the unit was as alluvial fans (Witkind and Thaden, 1963). The Shinarump Conglomerate west of the site at the location of the Monument No. 2 Mine (Figure 2.3) was the source of vanadium and uranium ore. 
The Shinarump Conglomerate is present at land surface west of the site (in the vicinity of the Monument No. 2 Mine) and under the alluvial aquifer within Cane Valley. Well logs indicate that it is up to $90 \mathrm{ft}(30 \mathrm{~m})$ thick at well 664 (near the center of Cane Valley) but is not present at well 657 (near the north boundary of the site). Well 657 probably is in the area of a buried channel, which appears to have eroded the unit.

\section{Hydrology}

Ground water within the Shinarump Conglomerate occurs under both unconfined and semiconfined conditions. Most water within the Shinarump Conglomerate is under semiconfined conditions where the upper portions of the unit are finer-grained and act as the semiconfining layers of rock. Water is unconfined where outcrops of the Shinarump Conglomerate are present at land surface. However, in the site vicinity, unconfined portions of the Shinarump Conglomerate are not common because water usually is not present in the unit where it outcrops (i.e., the depth to water is usually greater than the depth to the bottom of the unit where it outcrops).

Water level measurements at the site indicate ground water within the Shinarump flows north (Figure 2.6). The hydraulic gradient for the Shinarump Conglomerate is 0.01 , based on the water levels measured in December 1994.

The hydraulic conductivity was estimated from slug tests conducted in four monitoring wells in the Shinarump Conglomerate. Values range from 0.4 to $8 \mathrm{ft}(0.1$ to $2 \mathrm{~m})$ per day (DOE, 1993). The porosity is estimated to be about 0.25 (DOE, 1995). Using a gradient of 0.01 , a hydraulic conductivity of 0.4 to $8 \mathrm{ft}(0.1$ to $2.4 \mathrm{~m})$ per day, and a porosity of 0.25 , the velocity may range from 6 to $100 \mathrm{ft}(2$ to $30 \mathrm{~m})$ per year.

Recharge to the Shinarump Conglomerate is from rainfall in the outcrop area and from upward leakage from the De Chelly Sandstone in some areas. Discharge from the Shinarump Conglomerate probably is limited to the alluvial aquifer.

There are no known water supply wells in the Shinarump Conglomerate in the site vicinity.

\section{Moenkopi Formation}

\section{Geology}

The Moenkopi Formation is a dark- to reddish-brown shaley siltstone and sandstone that underlies the Shinarump Conglomerate. The color of the Moenkopi Formation contrasts greatly with the light gray of the Shinarump Conglomerate and the light tan of the De Chelly Sandstone. The unit likely was deposited in a near-shore mud-flat type of environment, where lagoons, playas, and deltas formed (Witkind and Thaden, 1963).

The Moenkopi formation is not present near the northern site boundary (well 657), where a buried channel has completely eroded the unit. Where present in the site vicinity, the Moenkopi Formation is up to about $60 \mathrm{ft}(20 \mathrm{~m})$ thick. 
Figure 2.6

Shinarump Conglomerate Piezometric Surface, 7-8 December 1994

Monument Valley, Arizona, Site

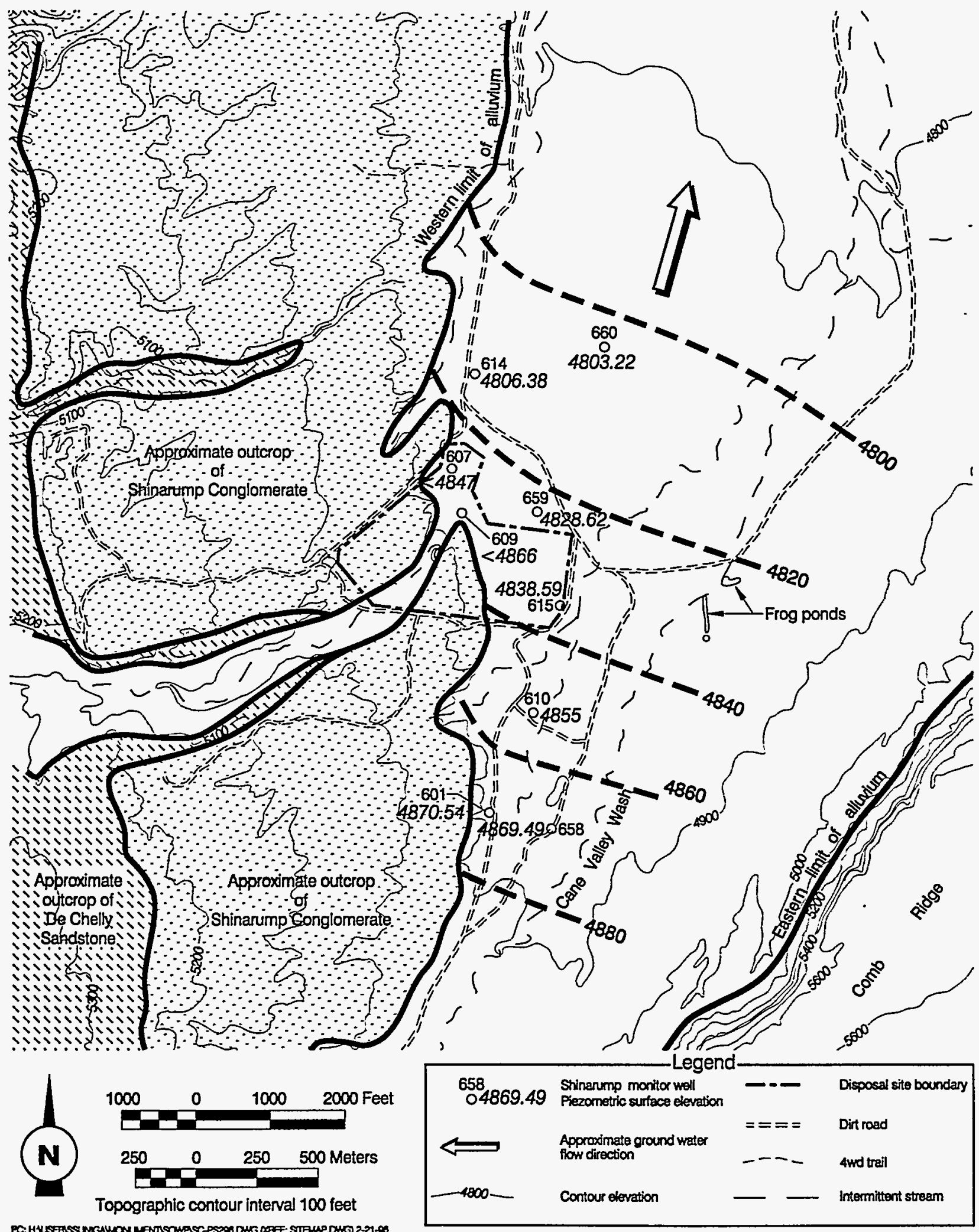




\section{Hydrology}

The Moenkopi Formation acts as a confining unit due to the fine-grained nature of its sediments. Calcium carbonate, silica, and iron oxide are present as intergranular cement (Witkind and Thaden, 1963) that restricts pore spaces and decreases the hydraulic conductivity. The hydraulic conductivity is estimated to be several orders of magnitude lower than the overlying and underlying formations.

The degree to which the Moenkopi Formation acts as a confining unit depends on its low hydraulic conductivity and thickness. Because the thickness of the unit varies, its effectiveness as a confining unit also varies. The unit is absent in the vicinity of well 657 , which has resulted in the alluvial aquifer and De Chelly Sandstone being in hydraulic connection in that area. Generally, there is an upward hydraulic gradient between the De Chelly Sandstone and the overlying aquifers. The gradient was probably reversed during pumping of former mill supply wells; however, the wells are no longer pumped, so the upward gradient has reestablished.

The low hydraulic conductivity of the Moenkopi Formation and its minimal ability to transmit ground water make it an inappropriate zone in which to screen a well. Therefore, piezometric surface maps have not been made, and hydraulic gradient, hydraulic conductivity, and ground water velocities have not been estimated.

\section{De Chelly Sandstone}

\section{Geology}

The De Chelly Sandstone is a grayish-yellow-to-tan, fine-grained sandstone. Although none of the UMTRA Project wells fully penetrate the unit, Witkind and Thaden (1963) report that it is approximately $500 \mathrm{ft}(150 \mathrm{~m})$ thick in the area of the site. It is the lowest aquifer beneath the Monument Valley tailings site and is underlain by the lowpermeability Organ Rock Shale. The sand grains consists almost entirely of quartz, and the unit is weakly cemented with silica, calcium carbonate, and iron oxide. The iron oxide gives the De Chelly Sandstone unit its light brown color (Witkind and Thaden, 1963).

\section{Hydrology}

Ground water within the De Chelly Sandstone generally is confined by the overlying Moenkopi Formation. It is probably unconfined, or only partially confined in the vicinity of the buried channel near the northern site boundary.

The piezometric surface of the De Chelly Sandstone within Cane Valley ranges from slightly above ground surface to about $160 \mathrm{ft}(49 \mathrm{~m})$ below ground surface, due to variations in ground surface elevations across the valley (DOE, 1995). Wells completed in the De Chelly Sandstone will flow where the piezometric surface is above ground surface. This generally occurs in the topographically lower portions of Cane Valley (e.g., at wells 611,613 , and 625). Areas west of the site are topographically higher, and the depth to the piezometric surface is greater. 
Figure 2.7 presents the piezometric surface map for the De Chelly Sandstone for December 1994. Ground water flows generally north. Based on December 1994 water level elevations, the hydraulic gradient is 0.01 . The hydraulic conductivity computed from an aquifer pumping test in the De Chelly Sandstone is estimated at 0.02 to $6 \mathrm{ft}(0.006$ to $2 \mathrm{~m})$ per day (DOE, 1993).

Comparison of ground water levels in wells completed in the De Chelly Sandstone and wells completed in the overlying alluvium show an upward hydraulic gradient. Water levels in the De Chelly aquifer are about 10 to $20 \mathrm{ft}(3$ to $6 \mathrm{~m}$ ) higher than water levels in the alluvial aquifer. Where and when the upward gradient occurs, downward migration from the alluvium is prevented.

The porosity of the De Chelly Sandstone has not been measured; however, porosity can be estimated from Table 2.4 of Freeze and Cherry (1979). The unit consists of sandstone (with porosity of 0.05 to 0.30 ). Because the sandstone is fine-grained and contains some cementing materials, a good estimate of the effective porosity is near the lower portion of the range listed, and is likely about 0.15 .

Using a gradient of 0.01 , a hydraulic conductivity of 0.02 to $6 \mathrm{ft}(0.006$ to $2 \mathrm{~m})$ per day, and a porosity of 0.15 , the velocity is estimated at 0.8 to $150 \mathrm{ft}(0.2$ to $46 \mathrm{~m})$ per year.

The De Chelly Sandstone is recharged by infiltration of rainfall and snowmelt. Although precipitation is limited, the De Chelly Sandstone has a relatively large outcrop area along Cane Valley, west and south of the site. Much of the bedrock outcrop is buried beneath alluvial and windblown sands and water may infiltrate rapidly through these sands and into the De Chelly aquifer. Loss of recharge to plants is limited, due to the sparse vegetation where the sandstone is exposed at land surface. Discharge is through springs and wells (e.g., the frog ponds and well 625), through vertical leakage into overlying units, and through water-supply wells for domestic and stock use.

\subsubsection{Surface water hydrology}

Surface water features in the vicinity of the Monument Valley site include Cane Valley Wash, several small drainage channels (arroyos), and several ponds known locally as the frog ponds (Figure 2.4). Cane Valley Wash flows roughly south to north, with a drainage area of approximately 90 square miles $\left(\mathrm{mi}^{2}\right)$ (230 square kilometers $\left[\mathrm{km}^{2}\right]$ ) south of the UMTRA Project site (DOE, 1993).

Surface water flow in the small drainage channels in the site vicinity is ephemeral (i.e., occurring only after heavy rainfall or snowmelt), as is flow along the length of Cane Valley Wash. However, small pools within the wash have standing water for prolonged periods (several weeks or longer). Water in these pools is a result of the water table intersecting land surface. As water levels decline, the pools get smaller and eventually go dry. The exact locations of all of the pools, their size, and duration are not known, but the pools begin in the wash east of monitor well 658 and occur downstream (north) for several miles. 
Figure 2.7

De Chelly Piezometric Surface, 7-8 December 1994

Monument Valley, Arizona, Site

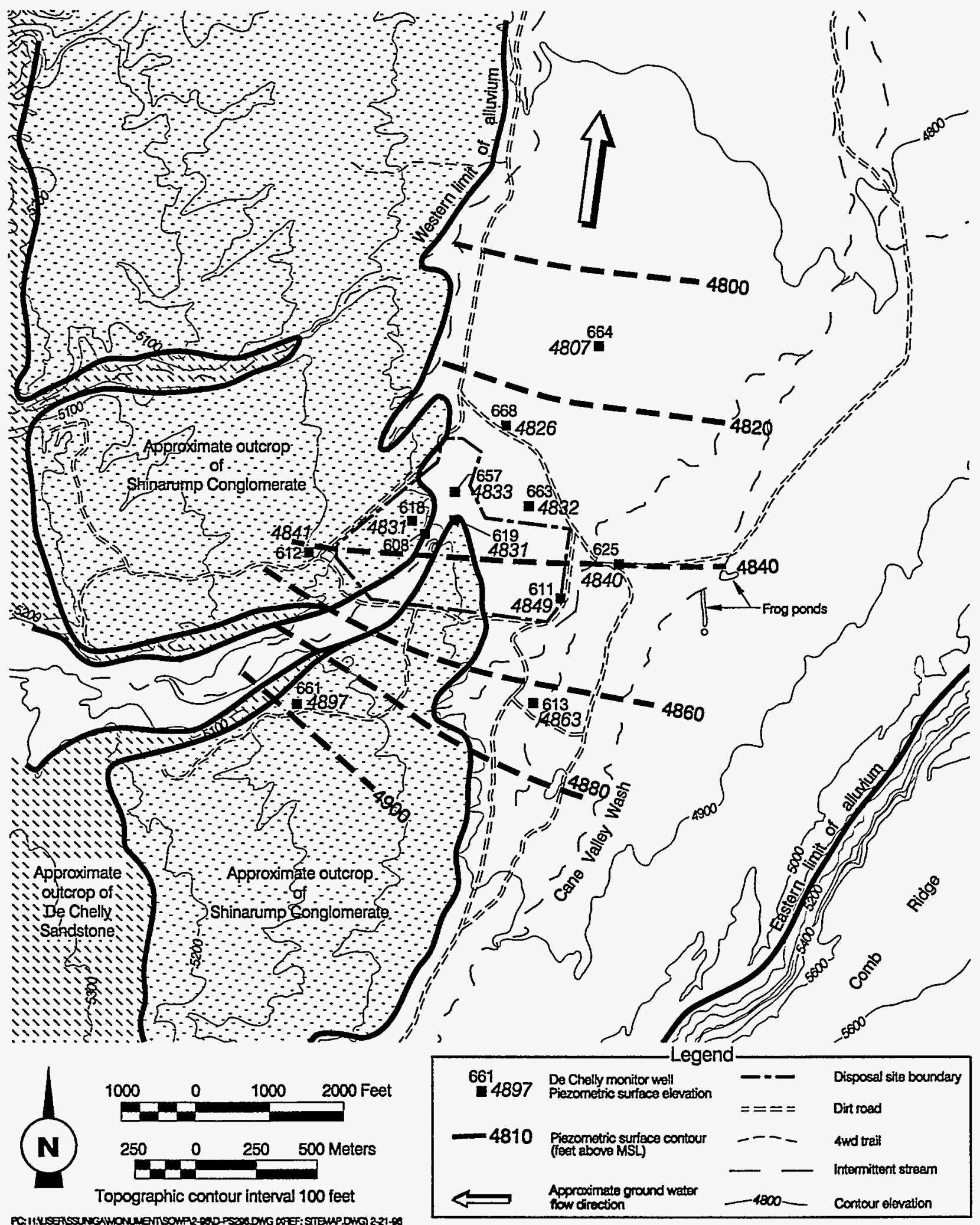

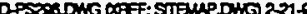


The most obvious surface water features in the site vicinity are the frog ponds. They contain water all year, likely as a result of discharge from the De Chelly aquifer. There have been reports that old wells may exist in the vicinity of the ponds that allow flow from the De Chelly into the ponds. No wells are visible at land surface in the vicinity of the ponds. The confining units above the De Chelly Sandstone are absent or thin.

The ponds act as a local recharge area to the alluvial aquifer, based on the configuration of the water table in the vicinity of the ponds (Figure 2.5), with ground water flowing away from the ponds as a result of a ground water mound in that area. If the ponds were an area of discharge from the alluvial aquifer (i.e., if the ponds were fed by water from the alluvial aquifer), the water-table contours would show the ponds as a low area, and ground water in the alluvial aquifer would flow toward (not away from) the ponds.

\section{$2.4 \quad$ LAND USE}

Individual members from the Navajo Nation do not literally own land; several systems of land tenure maintain land use rights. The Navajo system for land assignment consists of grazing permits. The grazing permit system developed in the 1940 s assigns land based on sheep units. A Navajo cannot establish a residence without a grazing permit. These permits are usually passed down or subdivided among family members. The BIA oversees permit registration.

Figure 2.2 shows the location of area residences. One occasional and six year-round residences exist within a $1-\mathrm{mi}(1.6-\mathrm{km})$ radius of the site. Two of the year-round residences lie due south of the tailings pile, and four residences are located along Cane Valley Wash, east and slightly south of the pile. The remaining full-time residence is adjacent to the site at the northeast corner. Three additional residences are located along BIA service road 6440 within $2 \mathrm{mi}(3.2 \mathrm{~km})$ north of the site.

Most residents of the valley maintain small herds of cattle, goats, and/or sheep. These animals range freely throughout the valley, but the primary grazing area is a meadow in Cane Valley. The meadow is supported by drainage from the frog ponds

1 running north through the valley for several miles (see Figure 2.4). Several residents also maintain vegetable gardens consisting primarily of corn, squash, and melons.

\subsection{WATER USE}

Because of the limited and highly variable surface water supply in the area, ground water is an important resource. The indian Health Service (IHS) funds and arranges installation of wells and water systems on the Navajo Reservation. 
In addition to DOE-placed monitor wells, five points of ground water withdrawal are known to exist within a $2.5-\mathrm{mi}(4.0-\mathrm{km})$ radius of the pile (Figure 2.4$)$ :

- An IHS hand-pump well at each of the two residences due south of the pile (wells 616 and 617).

- One hand-pump well (640) southeast of the site along Cane Valley Wash. This well is not currently in use.

- A windmill-pump well at a residence $2 \mathrm{mi}(3.2 \mathrm{~km})$ north of the site.

- An IHS well in Cane Valley Wash, approximately $2.5 \mathrm{mi}(4.0 \mathrm{~km})$ north and slightly east of the site.

Homes in the Monument Valley site vicinity do not have indoor plumbing or sewage systems. Domestic water use encompasses drinking, bathing, and watering vegetable gardens and domestic pets. Livestock primarily drink surface water, as described in later sections.

Several families in the valley use the hand-pump wells at the residences south of the pile as a domestic water supply. These wells (616 and 617) have been monitored regularly as part of the UMTRA Ground Water Project monitoring effort at the site. Their exact completion depth is unknown. Water quality and geochemistry in wells 616 and 617 cannot be distinguished from upgradient water samples from either the alluvial or De Chelly aquifers.

The hand-pump well (well 640) southeast of the site in Cane Valley Wash is not in use due to the bitter taste of the water. Surveys of area residents conducted in 1992 and 1993 indicated that residents in this well's vicinity carry their water from either well 616 or 617 or use water flowing from artesian monitor well 613 , completed in the De Chelly Formation.

The residents at the northeast corner of the site use water from a flowing artesian well (625) that was a former production well for the milling operation. This well also is completed in the De Chelly Formation and is monitored regularly by the UMTRA Project. No contamination has been observed in this well.

Residents living north of the site along BIA road 6440 obtain their water from the windmill-pump well, which also appears to be completed in the De Chelly Formation. This well also is used to fill a stock pond located on the same property. Livestock drink water pooling around artesian monitor wells 613 and 625 and from the frog ponds and the ephemeral stream in Cane Valley Wash. U.S. Geological Survey (USGS) maps reveal at least one additional spring approximately $2 \mathrm{mi}$ (3.2 $\mathrm{km}$ ) north of the site, east of road 6440 near surface sampling location 620; this spring drains to Cane Valley Wash. During periods of drought, residents dig out springs in the valley to water their stock. This has occurred both in the vicinity of the frog ponds and in the spring region north of the site around sampling location 620. While only these two instances have been verified, it is likely that this type of ground water access also occurs at other locations. 


\subsection{EXTENT OF CONTAMINATION}

The DOE collected ground water quality data from the former processing site and vicinity from April 1985 through December 1994 (DOE, 1996b). A total of 38 wells were sampled, including 32 DOE monitor wells, 3 former Vanadium Corporation of America water wells used for processing uranium and vanadium ores, and 3 private wells. These wells were completed in different hydrogeologic units, including the alluvial aquifer, the Shinarump Conglomerate, and the De Chelly Sandstone. Table 2.1 lists these wells by hydrogeologic zone of completion and location (upgradient, crossgradient, or downgradient). Figure 2.4 shows the location of wells at the Monument Valley site.

Ground water and surface water quality data obtained from April 1988 through December 1994 are used to assess ground water and surface water quality. Only data collected after 1987 were used due to the improved analytical detection limits and quality control procedures for this period. Data from one to eight sampling rounds were incorporated from each sampling location.

From April 1988 through December 1994, most ground water samples were filtered prior to analysis. However, unfiltered samples were also available. One round of unfiltered samples was collected from two wells (614 and 616) for analyses for all constituents. Additionally, unfiltered samples were collected and analyzed from 29 wells (at least once and up to 8 times) for most constituents, including major elements and ammonium, arsenic, barium, cadmium, chromium, manganese, iron, molybdenum, radium-226, radium-228, selenium, strontium, uranium, vanadium, and zinc. Data from analyses of unfiltered ground water samples generally were not available for aluminum, beryllium, boron, bromide, cobalt, copper, mercury, nickel, silver, and tin. An analysis of paired filtered and unfiltered data indicates that, for most constituents, there are no notable differences (DOE 1996b). The exceptions are iron, lead-210, manganese, and zinc, which show higher concentrations in the unfiltered samples, because a portion of these metals are apparently being adsorbed onto suspended particles in ground water.

Organic solvents were probably not used in the milling process. Nonetheless, in 1990, ground water from the site was screened for organic constituents (Hill, 1989; DOE, 1989) listed in Appendix IX of the Resource Conservation and Recovery Act (40 CFR Part 264). This screening included one tailings solution sample and one ground water sample. Common laboratory-derived contaminants such as phthalates were detected in either the tailings or ground water samples at levels near the laboratory method detection limit (MDL). Methyl iodide was reported in the ground water below the MDL; however, it is unlikely that this compound, if truly present in the ground water, is related to site activities. The herbicide 2,4,5-T was detected in the tailings solution near the MDL, but not in ground water. No other organic constituents were detected in this screening.

Tailings solutions were sampled for inorganic constituents in October 1985 and April 1986. Samples were collected at the new tailings pile and evaporation pond using suction lysimeters. At each location, lysimeters were installed at different depths. At the new tailings pile, lysimeters were installed at $5,10,15$, and $20 \mathrm{ft}(1.5,3.0,4.6$, and $6.1 \mathrm{~m})$ below the tailings surface (lysimeters $814,815,816$, and 817 , respectively). At the evaporation pond area east of 
the new tailings pile, lysimeters were installed at 15 and $20 \mathrm{ft}(4.5$ and $6.1 \mathrm{~m}$ ) below the surface (lysimeters 805 and 804, respectively) (DOE, 1996b).

Samples of tailings solution were not collected from the old tailings pile. However, data from analyses of two water leachate samples from this pile are available.

Surface water and near-surface water samples were collected from the frog ponds east of the site and from locations in Cane Valley Wash. Surface water samples were collected from the frog ponds from June 1982 through December 1994 (DOE, 1996b). These pond samples were collected at three separate locations $(621,622$, and 623$)$. Surface water samples were collected in December 1993 and 1994 from a shallow pool about $1200 \mathrm{ft}(370 \mathrm{~m})$ downstream of the frog ponds in Cane Valley Wash (624), and in December 1993 from a second shallow pool about $3400 \mathrm{ft}(1030 \mathrm{~m})$ downstream of the frog ponds. A near-surface water sample was collected about $1 \mathrm{mi}(1.6 \mathrm{~km})$ downstream by digging a 2 - $\mathrm{ft}(0.6 \mathrm{~m})$-deep hole in the bed of the wash and allowing it to fill with water seeping from the alluvium (location 627). Three rounds of data are available from this location. Both filtered and unfiltered data are available for surface and near-surface water samples. One analysis is available from a sample collected in 1993 from a spring west of Cane Valley Wash (location 620).

Sediment samples were collected in June 1993 from the frog ponds location 623; Cane Valley Wash surface water locations $620,624,625$; and near-surface water location 627 (DOE, 1996b). Figure 2.4 shows all surface water and sediment sampling locations.

\subsection{BACKGROUND GROUND WATER QUALITY}

To illustrate the general quality of various ground waters, median concentrations of constituents are used in summary tables within this section. In most cases, these median values are representative of water quality.

\subsubsection{Alluvial aquifer}

Background ground water quality is defined as the quality the water would be if uranium milling activities had not taken place. Background ground water quality data for the alluvial aquifer near the processing site are available from upgradient monitor wells 602 , crossgradient well 603, and from upgradient private wells 616 and 617 (Figure 2.4) (DOE, 1996b). Crossgradient wells 604, 605, and 654 are located downgradient of vicinity property surface contamination and, thus, are not suitable as background wells. Well 640 , an upgradient domestic well, has only been sampled once and there is not sufficient data for use as a background well.

Water quality is similar in wells $602,603,616$, and 617. (Table 3.1). Total dissolved solids (TDS) range from about 400 to 450 milligrams per liter (mg/L). The predominant anion is bicarbonate (reported as alkalinity in Table 3.1) with lesser amounts of sulfate and chloride. The predominant cation is sodium with lesser amounts of magnesium, calcium, potassium, and strontium. Nitrate (expressed as $\mathrm{NO}_{3}$ ) is present over a range of less than 0.04 to $44 \mathrm{mg} / \mathrm{L}$, with a median concentration of about $5 \mathrm{mg} / \mathrm{L}$. Commonly detected trace constituents include iron, manganese, and uranium. The water has a pH above neutral $(\mathrm{pH}$ of about 7.8 to 8.2), and the oxidation-reduction (redox) condition is oxidizing (redox potential of about 400 to 450 millivolts [mV]). 
Table 3.1 Background ground water quality in the alluvial aquifer, Monument Valley, Arizona, site

\begin{tabular}{|c|c|c|c|c|}
\hline \multirow[b]{2}{*}{ Constituent } & \multicolumn{4}{|c|}{ Well location } \\
\hline & MON-01-0602 & MON-01-0603 & MON-01-0616 & MON-01-0617 \\
\hline Alkalinity & 217 & 200 & 242 & 270 \\
\hline Aluminum & $<0.05$ & $<0.05$ & $<0.05$ & 0.06 \\
\hline Ammonium & $<0.1$ & 0.3 & $<0.1$ & $<0.01$ \\
\hline Arsenic & 0.005 & 0.005 & $<0.01$ & $<0.01$ \\
\hline Barium & 0.05 & 0.05 & 0.11 & 0.08 \\
\hline Bromide & 0.2 & 0.1 & $<0.1$ & NA \\
\hline Cadmium & 0.0005 & 0.0005 & $<0.001$ & 0.0015 \\
\hline Calcium & 28 & 19 & 36 & 23 \\
\hline Chloride & 15 & 12 & 12 & 23 \\
\hline Fluoride & 0.2 & 0.15 & 0.3 & NA \\
\hline Iron & $<0.03$ & $<0.03$ & $<0.03$ & $<0.1$ \\
\hline Iron (unfiltered) & 0.15 & 0.12 & 0.14 & 0.23 \\
\hline Lead-210 & $<2.0$ & $<2.0$ & NA & NA \\
\hline Lead-210 (unfiltered) & $<2.0$ & $<2.0$ & 5.3 & 5.7 \\
\hline Magnesium & 19 & 14 & 30 & 42 \\
\hline Manganese & $<0.01$ & $<0.01$ & $<0.01$ & $<0.01$ \\
\hline Manganese (unfiltered) & 0.003 & 0.005 & 0.005 & 0.005 \\
\hline Mercury & $<0.0002$ & 0.0002 & $<0.0002$ & $<0.0002$ \\
\hline Molybdenum & 0.005 & 0.005 & $<0.007$ & 0.01 \\
\hline Nitrate as $\mathrm{NO}_{3}$ & 4.1 & 4.5 & 5.8 & 13.8 \\
\hline $\mathrm{pH}$ & 7.8 & 7.8 & 8.2 & 8.2 \\
\hline Phosphate & 0.2 & 0.3 & $<0.1$ & 0.1 \\
\hline Potassium & 1.9 & 2.5 & 1.1 & 0.6 \\
\hline Radium-226 & 0.7 & 0.4 & $<0.5$ & 2.9 \\
\hline Radium-228 & 0.8 & 1.2 & $<0.3$ & $<0.3$ \\
\hline Redox potential & 441 & 450 & NA & 407 \\
\hline Selenium & 0.004 & 0.003 & $<0.005$ & $<0.005$ \\
\hline Silica & 14 & 12 & 26 & 31 \\
\hline Sodium & 100 & 100 & 72 & 111 \\
\hline Strontium & 0.28 & 0.24 & 0.47 & 0.52 \\
\hline Sulfate & 130 & 115 & 134 & 123 \\
\hline Sulfide & 0.28 & 0.28 & $<1$ & NA \\
\hline
\end{tabular}


Table 3.1 Background ground water quality in the alluvial aquifer, Monument Valley, Arizona, site (Concluded)

\begin{tabular}{lcccc}
\hline & \multicolumn{4}{c}{ Well location } \\
\cline { 2 - 5 } Constituent & 1 & $<1$ & $<1$ & NA \\
\hline Thorium-230 & 441 & 396 & 420 & 450 \\
TDS & 0.004 & 0.003 & 0.004 & 0.007 \\
Uranium & $<0.005$ & $<0.005$ & $<0.01$ & 0.01 \\
Vanadium & $<0.005$ & 0.013 & $<0.01$ & $<0.02$ \\
Zinc & 0.015 & 0.007 & 0.039 & 0.043 \\
Zinc (unfiltered) & & & & MON-01-0603 \\
\hline
\end{tabular}

Notes:

1. Data listed are median concentrations for filtered samples (except as noted) collected from 1988 through 1994.

2. All data in milligrams per liter ( $\mathrm{mg} / \mathrm{L}$ ) except for the following: lead-210, radium-226, radium-228, thorium-230 in picocuries per liter; $\mathrm{pH}$ in standard units; oxidation-reduction (redox) potential in millivolts; alkalinity as $\mathrm{mg} / \mathrm{L}$ calcium carbonate equivalent.

3. < indicates less than the given value.

4. NA = not analyzed.

5. The following were never detected in either filtered or unfiltered background ground water (method detection limit is given in parentheses): antimony (0.003), beryllium (0.005), boron (0.05), chromium (0.005), cobalt (0.03), copper (0.01), lead (0.001), nickel (0.04), silver (0.01), thallium (0.01), and tin (0.005). 


\subsubsection{Shinarump Conglomerate aquifer}

Background ground water quality data for the Shinarump aquifer are available from upgradient monitor wells 601 and 615 (Figure 2.4). Too few data are available from upgradient wells 610 and 658 for use in determining background ground water quality. Ground water in the Shinarump is a sodium carbonate type, similar in composition to that in the alluvial aquifer (Table 3.2). TDS range from about 300 to $430 \mathrm{mg} / \mathrm{L}$. The water $\mathrm{pH}$ is above neutral ( $\mathrm{pH}$ of about 7.8), and the redox condition is oxidizing (redox potential of about 250 to $440 \mathrm{mV}$ ). Trace constituents are similar to those in the alluvial aquifer and include uranium. Nitrate is present with a median concentration of about $4 \mathrm{mg} / \mathrm{L}$. Particulate (filterable) concentrations of iron, manganese, and zinc are high in the background wells, with concentrations of iron in unfiltered samples ranging up to $107 \mathrm{mg} / \mathrm{L}$ (Table 3.2).

\subsubsection{De Chelly Sandstone aquifer}

Background ground water quality data for the De Chelly Sandstone aquifer are available from upgradient monitor wells 612 and 613 (Figure 2.4). Ground water in the De Chelly Sandstone is a calcium-magnesium-carbonate type. The water is chemically similar to that in the alluvial and Shinarump Conglomerate aquifers, but has somewhat less sodium and is more dilute (Table 3.2). TDS range from about 200 to $300 \mathrm{mg} / \mathrm{L}$. The water $\mathrm{pH}$ is above neutral ( $\mathrm{pH}$ of about 7.6 to 8.0), and the redox condition is oxidizing (redox potential of about $450 \mathrm{mV}$ ). Trace constituents include cadmium, molybdenum, uranium, and vanadium. Nitrate is present with median concentrations ranging from 4.3 to $8 \mathrm{mg} / \mathrm{L}$.

\subsection{NATURE AND EXTENT OF CONTAMINATION}

\subsubsection{Sources of ground water contamination}

There were two major sources of ground water contamination at the site: the old tailings pile/heap-leach pad and the new tailings pile (Figure 2.2). The old tailings pile was composed of the sand tailings, which were a residual product of the mechanical upgrading of ore. The upgrading process used water that contained a minor amount of flocculents but no other processing chemicals. Thus, tailings solutions in the old pile basically were water-equilibrated to minerals in the ore. Old tailings were placed on the heap-leach pad, and sulfuric acid was added to the tailings. Heap leaching of these old tailings occurred in the area where they were stored. Heap-leach pads were lined to collect the leachate that contained sulfuric acid.

By contrast, the new tailings pile contained both sand tailings and processing solutions. The processing solutions contained sulfate, nitrate, and ammonium from the processing chemicals.

Table 3.3 summarizes results of analyses of solutions in or derived from the old and new tailings piles. There are no direct analyses of tailings solutions from the old pile. However, leaching experiments on tailings collected from the old pile demonstrate that water in contact with the old tailings would contain primarily calcium and sulfate 
Table 3.2 Background ground water quality in the Shinarump Conglomerate and De Chelly Sandstone aquifers, Monument Valley, Arizona, site

\begin{tabular}{|c|c|c|c|c|}
\hline \multirow[b]{2}{*}{ Constituent } & \multicolumn{2}{|c|}{ Shinarump Conglomerate } & \multicolumn{2}{|c|}{ De Chelly Sandstone } \\
\hline & MON-01-0601 & MON-01-0615 & MON-01-0612 & MON-01-0613 \\
\hline Alkalinity & 280 & 226 & 121 & 185 \\
\hline Aluminum & 0.07 & $<0.1$ & NA & $<0.1$ \\
\hline Ammonium & 0.13 & $<0.1$ & $<0.1$ & $<0.1$ \\
\hline Antimony & 0.004 & $<0.003$ & $<0.003$ & $<0.003$ \\
\hline Arsenic & $<0.005$ & 0.003 & $<0.01$ & $<0.005$ \\
\hline Barium & 0.05 & 0.05 & NA & 0.05 \\
\hline Cadmium & 0.0004 & 0.0003 & 0.004 & 0.0005 \\
\hline Calcium & 28 & 18 & 28 & 16 \\
\hline Chloride & 15 & 10 & 6 & 8 \\
\hline Fluoride & 0.2 & 0.4 & NA & 0.3 \\
\hline Iron & $<0.03$ & 0.14 & NA & $<0.03$ \\
\hline Iron (unfiltered) & 107 & 2.95 & NA & 0.04 \\
\hline Lead-210 & $<2$ & $<7.3$ & NA & $<2.0$ \\
\hline Lead-210 (unfiltered) & $<2$ & 7.2 & NA & 5.8 \\
\hline Magnesium & 18 & 16 & 18 & 29 \\
\hline Manganese (unfiltered) & 1.46 & 0.35 & NA & 0.005 \\
\hline Molybdenum & 0.005 & $<0.005$ & 0.01 & 0.005 \\
\hline Nitrate as $\mathrm{NO}_{3}$ & 4.3 & 4.3 & 8.0 & 4.3 \\
\hline $\mathrm{pH}$ & 7.8 & 7.8 & 7.6 & 8.0 \\
\hline Phosphate (unfiltered) & 2.6 & $<0.1$ & NA & $<0.1$ \\
\hline Potassium & 1.9 & 3.1 & 5.3 & 2.8 \\
\hline Radium-226 & $<0.3$ & 1.2 & $\mathrm{NA}$ & $<0.3$ \\
\hline Radium-228 & 1.35 & 2.7 & NA & $<1.0$ \\
\hline Redox potential & 442 & 248 & NA & 446 \\
\hline Selenium & 0.005 & $<0.002$ & $<0.005$ & $<0.005$ \\
\hline Silica & 14 & 9 & NA & 11 \\
\hline Sodium & 99 & 88 & 13 & 50 \\
\hline Strontium & 0.29 & 0.63 & NA & 0.35 \\
\hline Sulfate & 125 & 63 & 20 & 60 \\
\hline TDS & 429 & 327 & 313 & 195 \\
\hline Uranium & 0.005 & 0.001 & 0.010 & 0.004 \\
\hline Vanadium & $<0.005$ & $<0.005$ & NA & 0.005 \\
\hline
\end{tabular}


Table 3.2 Background ground water quality in the Shinarump Conglomerate and De Chelly Sandstone aquifers, Monument Valley, Arizona, site (Concluded)

\begin{tabular}{lcclllc}
\hline & \multicolumn{2}{c}{ Shinarump Conglomerate } & & \multicolumn{2}{c}{ De Chelly Sandstone } \\
\cline { 2 - 3 } \cline { 6 - 7 } \multicolumn{1}{c}{ Constituent } & MON-01-0601 & MON-01-0615 & & MON-01-0612 & MON-01-0613 \\
\hline Zinc & $<0.005$ & 0.013 & & NA & $<0.005$ \\
Zinc (unfiltered) & 0.15 & 0.038 & & NA & 0.005 \\
\hline
\end{tabular}

Notes:

1. Data listed are median concentrations for filtered samples (except as noted) collected from 1988 through 1994. Only one analysis is available for well MON-01-0612.

2. All data in milligrams per liter ( $\mathrm{mg} / \mathrm{L}$ ) except for the following: lead-210, radium-226, radium-228, thorium-230 in $\mathrm{pCi} / \mathrm{L} ; \mathrm{pH}$ in standard units; redox potential in millivolts; alkalinity as $\mathrm{mg} / \mathrm{L}$ calcium carbonate equivalent.

3. < indicates less than the given value.

4. NA = not analyzed.

5. The following were never detected in either filtered or unfiltered background ground water (method detection limit is given in parentheses): beryllium (0.005), bromide $(0.1)$, chromium (0.005), cobalt (0.05), copper (0.02), mercury (0.0002), nickel $(0.04)$, silver $(0.01)$, sulfide $(0.1)$, thallium (0.01), and thorium-230 (1.0). 
Table 3.3 Chemistry of tailings solutions and leachates, Monument Valley, Arizona, site

\begin{tabular}{|c|c|c|c|}
\hline Constituent & $\begin{array}{c}\text { Leachate } \\
\text { (old tailings pile) }\end{array}$ & $\begin{array}{l}\text { Tailings solution } \\
\text { (new tailings pile) }\end{array}$ & $\begin{array}{c}\text { Tailings solution } \\
\text { (evaporation pond subsoil) }\end{array}$ \\
\hline Alkalinity & $\mathrm{NA}$ & 2 & 44 \\
\hline Aluminum & 1.8 & 5.5 & 0.9 \\
\hline Ammonium & NA & 1200 & 47 \\
\hline Antimony & NA & 0.003 & $<0.003$ \\
\hline Arsenic & 0.31 & $<0.01$ & $<0.01$ \\
\hline Barium & 0.14 & 0.3 & 0.5 \\
\hline Cadmium & 0.115 & $<0.001$ & $<0.001$ \\
\hline Calcium & 446 & 626 & 425 \\
\hline Chloride & 6.1 & 20 & 45 \\
\hline Chromium & 0.24 & 0.02 & 0.03 \\
\hline Cobalt & NA & 1.41 & 0.11 \\
\hline Copper & 0.55 & 0.11 & 0.04 \\
\hline Fluoride & NA & NA & 1.7 \\
\hline Iron & 1.2 & 1.86 & 0.04 \\
\hline Lead & 0.43 & $<0.01$ & $<0.01$ \\
\hline Magnesium & 97 & 78.3 & 135 \\
\hline Manganese & 35 & 3.94 & 0.77 \\
\hline Molybdenum & $<0.06$ & 0.32 & 0.24 \\
\hline Nickel & NA & 1.1 & 0.15 \\
\hline Nitrate as $\mathrm{NO}_{3}$ & NA & 530 & 570 \\
\hline $\mathrm{pH}$ & 6.3 & 4.3 & 7.2 \\
\hline Phosphate & NA & NA & NA \\
\hline Potassium & 48 & 21.9 & 5.2 \\
\hline Radium-226 & NA & 13 & 4.7 \\
\hline Radium-228 & NA & NA & NA \\
\hline Redox potential & 535 & NA & NA \\
\hline Selenium & $<0.06$ & $<0.005$ & $<0.005$ \\
\hline Silica & 6.6 & NA & NA \\
\hline Silver & NA & $<0.01$ & $<0.01$ \\
\hline Sodium & 97 & 70.7 & 362 \\
\hline Strontium & NA & 0.07 & 1.6 \\
\hline Sulfate & 1450 & 4510 & 1610 \\
\hline TDS & NA & 6850 & 2900 \\
\hline
\end{tabular}


Table 3.3 Chemistry of tailings solutions and leachates, Monument Valley, Arizona, site (Concluded)

\begin{tabular}{lccc}
\hline Constituent & $\begin{array}{c}\text { Leachate } \\
\text { (old tailings pile) }\end{array}$ & $\begin{array}{c}\text { Tailings solution } \\
\text { (new tailings pile) }\end{array}$ & $\begin{array}{c}\text { Tailings solution } \\
\text { (evaporation pond subsoil) }\end{array}$ \\
\hline Uranium & 0.74 & 0.075 & 1.08 \\
Vanadium & 6.2 & 1.08 & 0.91 \\
Zinc & NA & 3.9 & 0.13 \\
\hline
\end{tabular}

Notes:

1. Leachate data in milligrams per kilogram (mg/kg) except for $\mathrm{pH}$ (in standard units) and redox potential (in millivolts).

2. Data listed are maximum measured concentrations in filtered samples (or minimum measurement in the case of $\mathrm{pH}$ ).

3. Leachate data are from samples MV004-01 and MV004-02 (DOE, 1993).

4. Tailings solution data are from evaporation pond locations 804 and 805 and from new tailings piles locations 814 through 817 .

5. Tailings solution data in milligrams per liter ( $\mathrm{mg} / \mathrm{L})$ except for the following: radium-226 and radium-228 in picocuries per liter, $\mathrm{pH}$ in standard units, redox potential in millivolts; alkalinity expressed as $\mathrm{mg} / \mathrm{L}$ calcium carbonate equivalent.

6. < indicates less than the given value.

7. NA = not analyzed.

8. The following were not detected (method detection limit is given in parentheses): boron (0.1), mercury (0.0002), silver (0.01), and tin (0.005). 
and several trace constituents including arsenic, cadmium, chromium, copper, lead, uranium, and vanadium. These constituents probably are derived from the dissolution of ore-associated minerals in the tailings, including gypsum (calcium sulfate), uranyl vanadates, and minor amounts of copper-bearing minerals (Witkind and Thaden, 1963). The dissolution of the mineral gypsum (hydrous calcium sulfate) may explain the predominance of both calcium and sulfate in the old tailings leachates.

Direct analyses of tailings solutions are available from the new tailings pile (Table 3.3). In general, the concentrations of these solutions increased with increasing depth in the pile, reflecting seepage of the solutions to the base of the pile and infiltration of precipitation into the top of the pile. The tailings solutions were acid ( $\mathrm{pH}$ as low as 4.3). The solutions are ammonium-nitrate and calcium-sulfate solutions, reflecting the presence of gypsum in the ores, the dissolution of other calcium-bearing minerals in the ores, and the addition of sulfuric acid and ammonium nitrate to the processing solutions. Chloride levels are notably low in these solutions and about the same as in background ground waters. Metals and trace elements include aluminum, antimony, barium, chromium, cobalt, copper, iron, manganese, molybdenum, nickel, strontium, uranium, vanadium, and zinc. These elements were derived from the dissolution of the ores.

Solutions beneath the evaporation pond area differ from those in the tailings piles (Figure 2.2). Notably, the acidity of the solutions has been reduced by reactions with carbonate minerals in the subsoil. Also, the ammonium and sulfate concentrations decreased and sodium concentrations increased. These changes reflect reactions of the tailings solutions with the subsoil. The resulting solution is a calcium-sodiumnitrate-sulfate solution. As with the tailings solutions, chloride concentrations are notably low ( $45 \mathrm{mg} / \mathrm{L}$ ), only slightly exceeding background concentrations (up to 23 $\mathrm{mg} / \mathrm{L}$ ). All metals and trace elements (except antimony) present in the tailings solutions are also present in the evaporation pond area.

\subsubsection{Ground water contamination in the alluvial aquifer}

The alluvial aquifer is the aquifer most affected by the ground water contamination. Four constituents associated with the processing solutions serve as indicators for delineating the extent of ground water contamination: calcium, sulfate, nitrate, and uranium. All four occur in background ground water, but at lower levels than in the tailings solutions. Also, all four tend to be mobile in the ground water under the conditions of the site.

Maps showing the distribution of sulfate, nitrate, and uranium indicate there may be two separate sources of ground water contamination at the site (Figures 3.1, 3.2, and 3.3). The calcium distribution is not shown as a figure because it closely reflects the sulfate distribution. Contamination from one source appears to be about 1000 feet north of the site (northern area), while contamination from a second source is closer to the new tailings area (southern area). Table 3.4 compares constituent concentrations in water from tailings solutions and background to median values for the two wells displaying the greatest contamination levels in the southern and northern areas (wells 606 and 655, respectively). 
Figure 3.1

Distribution of Sulfate in the Alluvial Aquifer

Monument Valley, Arizona, Site

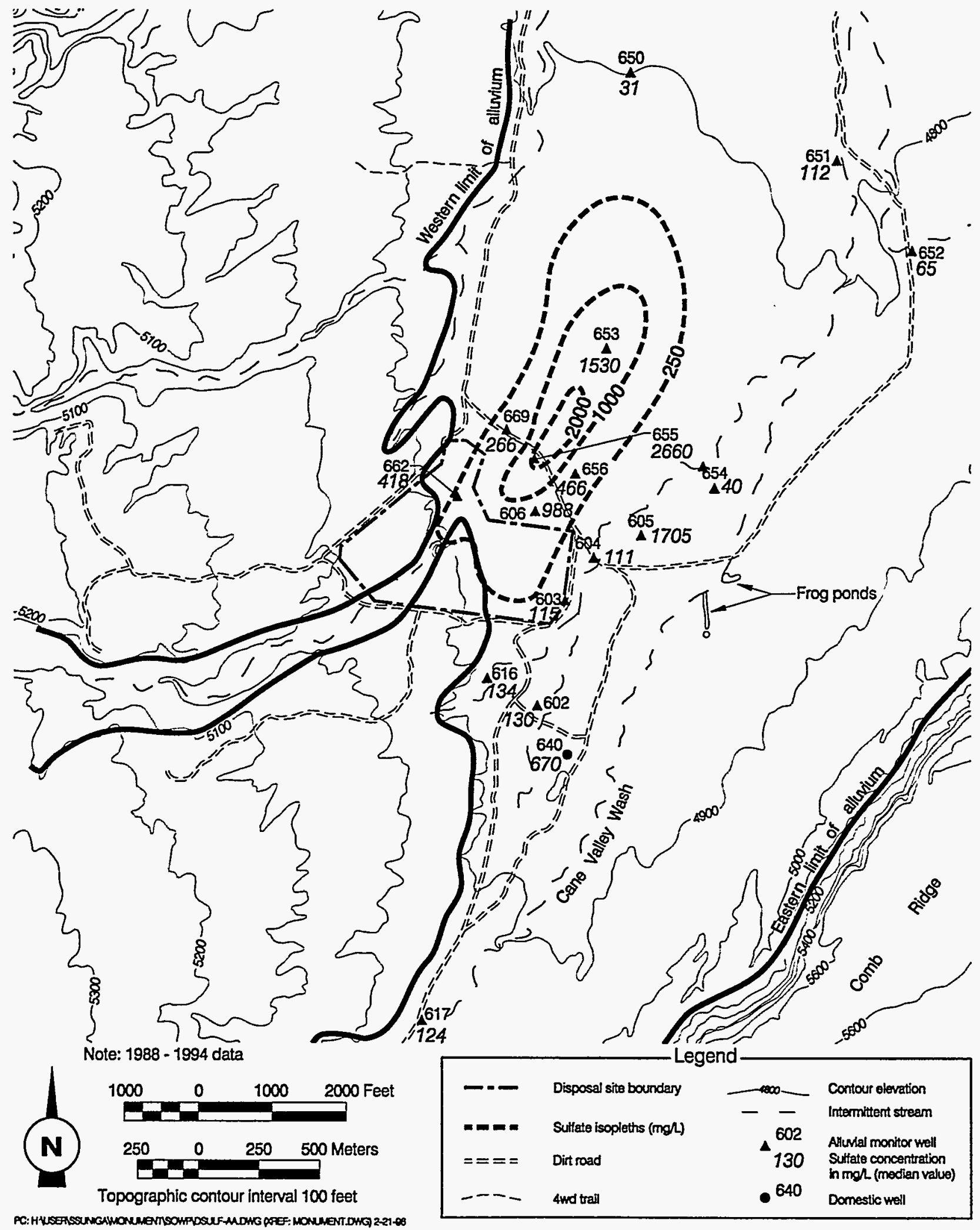


Figure 3.2

Distribution of Nitrate in the Alluvial Aquifer

Monument Valley, Arizona, Site

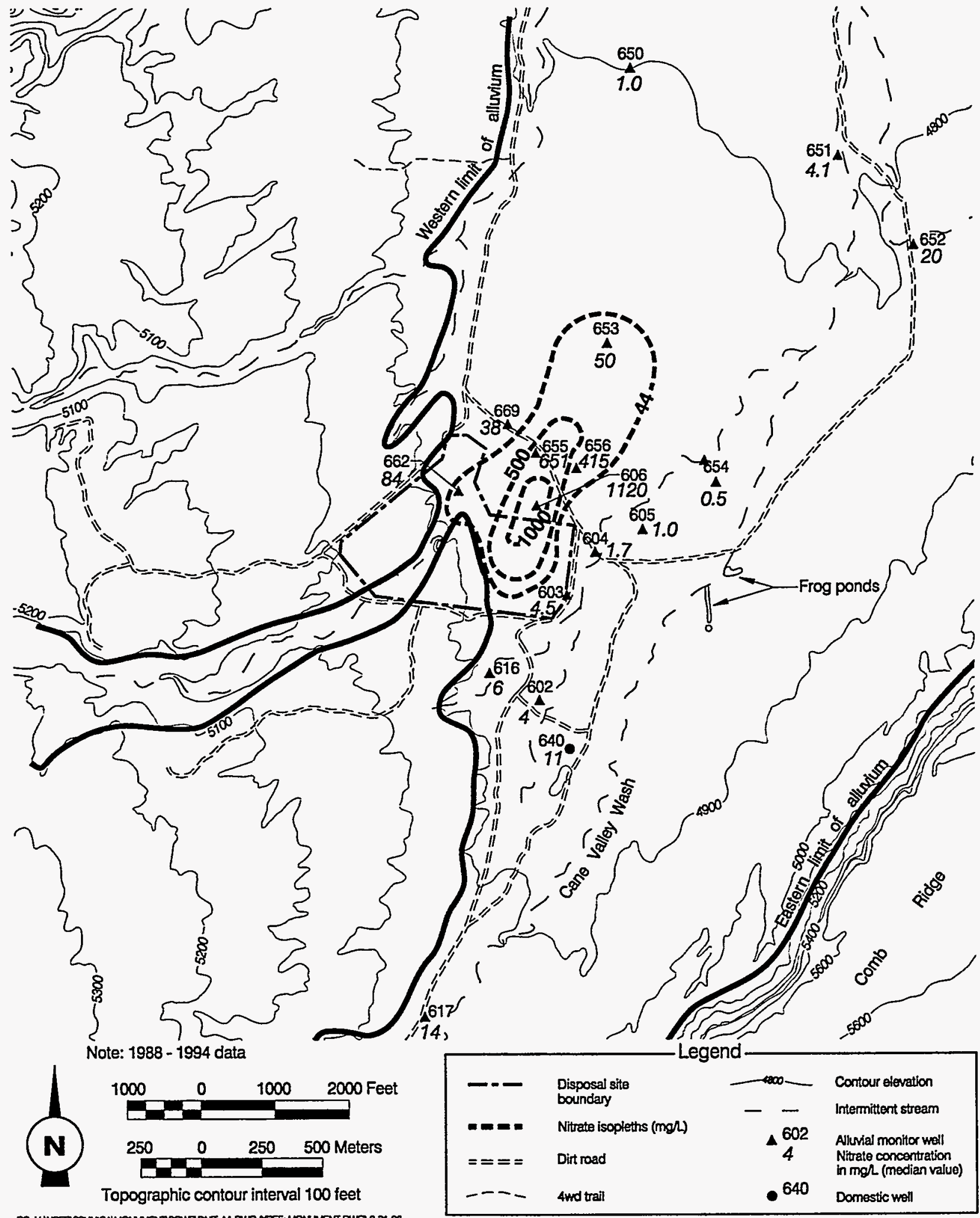

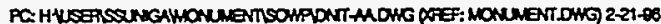


Figure 3.3

Distribution of Uranium in the Alluvial Aquifer

Monument Valley, Arizona, Site

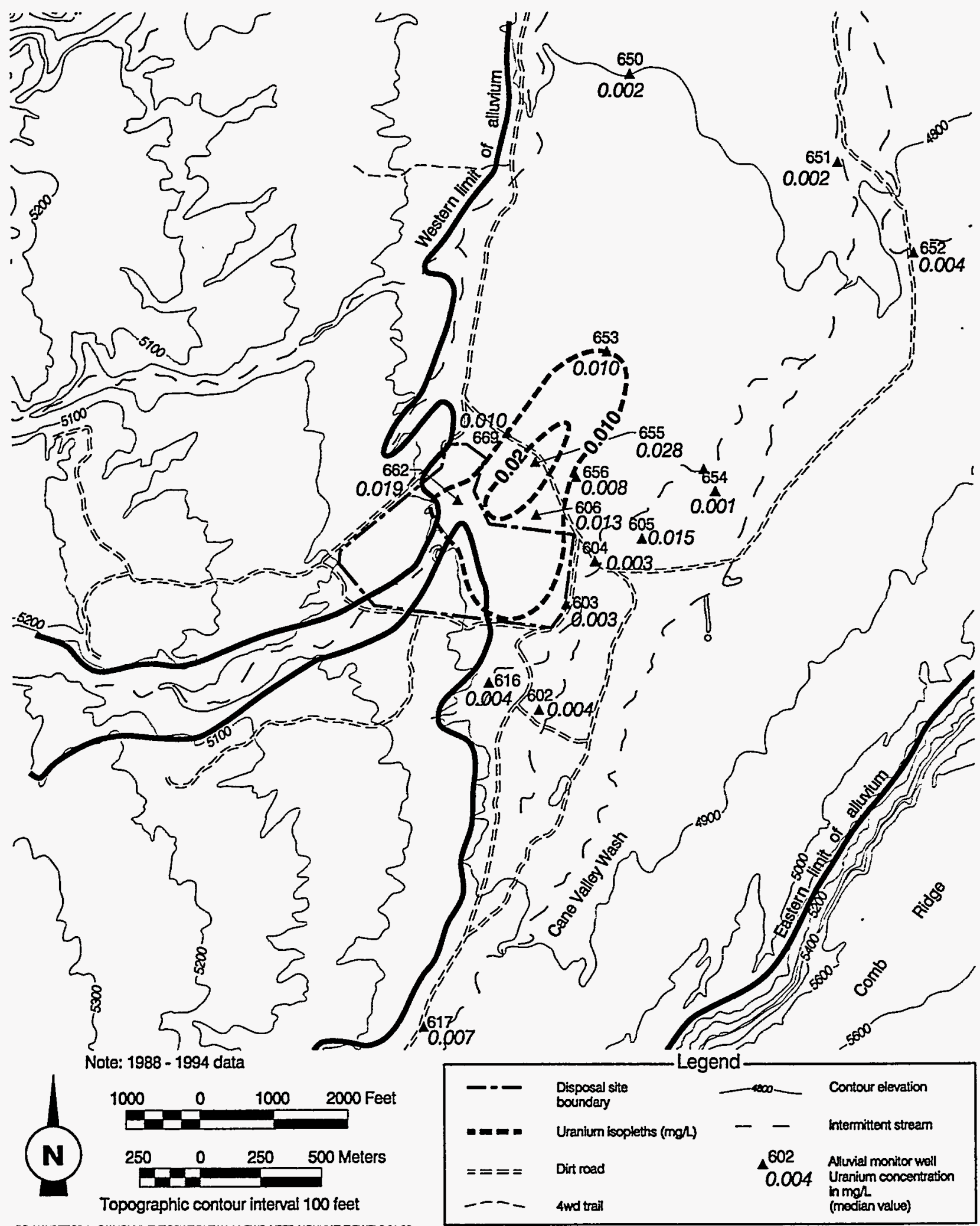

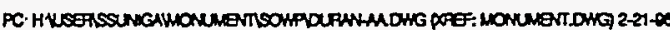


Table 3.4 Comparison of contaminated ground water to tailings solution and background ground water quality data in the alluvial aquifer, Monument Valley, Arizona, site

\begin{tabular}{|c|c|c|c|c|}
\hline Constituent & $\begin{array}{c}\text { Tailings solutions } \\
\text { (maximum } \\
\text { observed) }\end{array}$ & $\begin{array}{c}\text { MON-01-0606 } \\
\text { (contaminated) }\end{array}$ & $\begin{array}{l}\text { MON-01-0655 } \\
\text { (contaminated) }\end{array}$ & $\begin{array}{l}\text { MON-01-0617 } \\
\text { (background) }\end{array}$ \\
\hline Alkalinity & 44 & 316 & 307 & 268 \\
\hline Aluminum & 5.5 & $<0.1$ & $<0.1$ & $<0.1$ \\
\hline Ammonium & 1200 & 346 & 268 & $<0.01$ \\
\hline Antimony & 0.003 & $<0.003$ & $<0.003$ & $<0.003$ \\
\hline Arsenic & $<0.01$ & $<0.01$ & $<0.01$ & $<0.01$ \\
\hline Barium & 0.5 & 0.05 & 0.05 & 0.08 \\
\hline Bromide & NA & NA & NA & NA \\
\hline Boron & NA & 0.20 & $<0.05$ & NA \\
\hline Calcium & 626 & 226 & 410 & 22 \\
\hline Chloride & 45 & 17 & 32 & 23 \\
\hline Chromium & 0.03 & $<0.01$ & $<0.01$ & $<0.01$ \\
\hline Cobalt & 1.41 & $<0.05$ & $<0.05$ & $<0.05$ \\
\hline Copper & 0.11 & $<0.01$ & $<0.01$ & NA \\
\hline Fluoride & 1.7 & 0.4 & 0.2 & NA \\
\hline Iron & 1.86 & $<0.03$ & $<0.03$ & $<0.05$ \\
\hline Iron (unfiltered) & NA & 10.3 & 0.06 & 0.23 \\
\hline Lead-210 & NA & $<3.6$ & $<2.0$ & NA \\
\hline Lead-210 (unfiltered) & NA & 5.6 & 5.2 & 5.7 \\
\hline Magnesium & 135 & 122 & 306 & 41 \\
\hline Manganese & 3.94 & 0.11 & 0.04 & $<0.01$ \\
\hline Manganese (unfiltered) & NA & 0.20 & 0.05 & $<0.005$ \\
\hline Molybdenum & 0.32 & $<0.01$ & $<0.01$ & 0.01 \\
\hline Nickel & 1.1 & $<0.04$ & $<0.04$ & $<0.04$ \\
\hline Nitrate as $\mathrm{NO}_{3}$ & 570 & 1120 & 651 & 14 \\
\hline $\mathrm{pH}$ & 4.3 & 7.20 & 7.18 & 8.20 \\
\hline Phosphate & NA & 0.4 & 0.4 & NA \\
\hline Potassium & 22 & 12 & 27 & 0.6 \\
\hline Radium-226 & 13 & 0.35 & $<0.3$ & 2.9 \\
\hline Radium-228 & NA & 1.5 & $<1.0$ & $<1.0$ \\
\hline Redox potential & NA & 450 & 460 & 407 \\
\hline Selenium & $<0.005$ & $<0.005$ & $<0.005$ & $<0.005$ \\
\hline Silica & NA & 22 & 16 & 31 \\
\hline Sodium & 362 & 96 & 165 & 111 \\
\hline Strontium & 1.6 & 1.8 & 2.9 & 0.52 \\
\hline Sulfate & 4510 & 902 & 2270 & 103 \\
\hline
\end{tabular}


Table 3.4 Comparison of contaminated ground water to tailings solution and background ground water quality data in the alluvial aquifer, Monument Valley, Arizona, site (Concluded)

\begin{tabular}{lcccc}
\hline Constituent & $\begin{array}{c}\text { Tailings solutions } \\
\text { (maximum } \\
\text { observed) }\end{array}$ & $\begin{array}{c}\text { MON-01-0606 } \\
\text { (contaminated) }\end{array}$ & $\begin{array}{c}\text { MON-01-0655 } \\
\text { (contaminated) }\end{array}$ & $\begin{array}{c}\text { MON-01-0617 } \\
\text { (background) }\end{array}$ \\
\hline Tin & NA & $<0.005$ & $<0.005$ & NA \\
Thorium-230 & NA & $<1.0$ & $<1.0$ & NA \\
TDS & 6850 & 2084 & 4165 & 450 \\
Uranium & 1.08 & 0.013 & 0.028 & 0.007 \\
Vanadium & 1.08 & $<0.01$ & $<0.01$ & 0.018 \\
Zinc & 3.9 & 0.010 & 0.003 & $<0.005$ \\
Zinc (unfiltered) & NA & 0.029 & 0.019 & 0.043 \\
\hline
\end{tabular}

Notes:

1. Tailings solution data are the maximum observed values (minimum values for $\mathrm{pH}$ ) for filtered samples collected from lysimeters.

2. Ground water data listed are median values for filtered samples (except as noted) collected from 1988 through 1994.

3. All data in milligrams per liter (mg/L) except for the following: lead-210, radium-226, radium-228, thorium-230 in picocuries per liter; $\mathrm{pH}$ in standard units; redox potential in millivolts; alkalinity as $\mathrm{mg} / \mathrm{L}$ calcium carbonate equivalent.

4. < indicates less than the given value.

5. NA = not analyzed.

6. The following were not detected in samples of tailings solutions and ground water (method detection limit is given in parentheses): beryllium (0.005), cadmium (0.001), lead (0.01), mercury (0.0002), silver (0.01), and thallium (0.01). 
The northern area of contaminated ground water may be associated with the old tailings pile and heap-leach pad area, which were located on windblown sands overlying a buried channel, or perhaps with an older source of tailings solutions in the eastern portion of the site. This area of contaminated ground water is characterized by several constituents that occur at high levels above background, including sulfate, calcium, magnesium, strontium, and uranium.

The northern area of ground water contamination also contains nitrate. However, compared to background concentrations, elevated sulfate concentrations extend beyond the limits of elevated nitrate.

By contrast, the southern area of ground water contamination is characterized by the highest observed concentrations of nitrate and ammonium in ground water at the site. Other site-related constituents (sulfate and uranium) are present, but at lower levels than those observed to the north.

Contaminated ground water from both sources appears to converge in the area of monitor well 655 . The most contaminated ground water is the ammonium-nitrate calcium-sulfate water in the southern area, near well 606, and the calcium-nitratesulfate water in the northern area, near well 655.

Ground water sampled from monitor wells 606 and 655 represent the most contaminated ground water observed in monitor wells. However, both wells are downgradient of (rather than beneath) the former tailings piles. Lysimeter data, though old (1983), suggest that beneath the new tailings pile and evaporation pond area, the magnitude of contamination may be greater than that observed in downgradient monitor wells. This is supported by the fact that nitrate and ammonium concentrations near the new tailings pile (well 606) have not significantly decreased since 1985 (DOE, 1995).

In contrast to nitrate, concentrations of sulfate, TDS, calcium, magnesium, and uranium have decreased in alluvial wells within about $1000 \mathrm{ft}(300 \mathrm{~m})$ of the site (monitor wells 606, 655, and 669), while concentrations have increased in well 653 located about $2800 \mathrm{ft}(850 \mathrm{~m})$ from the site (DOE, 1995). These trends are consistent with inference that there is not a single source of contaminants.

It appears that the area of greatest ground water contamination associated with one source is presently located north of site (between wells 653 and 655) and continues to move north at a detectable rate. However, the area of greatest contamination associated with the second source, an ammonium and nitrate-rich source, appears to be closer to the new tailings pile area and moving at a slower rate. Thus, relatively high levels of constituents may still exist beneath the site, especially if some constituents were mobilized by surface remediation activities. More data are needed to confirm these suppositions.

Monitoring well 605, located east (crossgradient) of the site, has relatively high sulfate concentrations. Also, private well 640 (no longer operable), upgradient of the site, has relatively high sulfate concentrations compared to the ground water in other background wells. Uranium concentrations are also higher than in the other background locations (DOE, 1996b). However, ground water in these wells is not 
thought to be influenced by contaminated ground water flow, but by either salts concentrated by evaporation or naturally occurring soluble salts in the alluvial aquifer. This is indicated by 1) the fact that private well 640 is located upgradient of the site and therefore cannot be affected by contaminated ground water flow; 2) the lack of nitrate (above background levels) in these two wells; and 3) the presence of relatively high concentrations of chloride. As noted, chloride concentrations in the tailings pore fluids are low.

The elevated concentrations of chloride, calcium, magnesium, sodium, potassium, alkalinity, and uranium in wells 605 and 640 are consistent with evaporative concentration of natural ground water. During evaporation, concentrations of major elements tend to remain at constant proportions. Thus, while sulfate and chloride concentrations increase, their relative proportions remain the same. In background ground water, the sulfate-to-chloride ratio is about 11 to 1 or less. Ground water in wells 640 and 605 have sulfate-to-chloride ratios in the range of background (6 to 1 and 9 to 1 , respectively) (Figures 3.4 and 3.5).

By contrast, in the tailings solutions, the sulfate-to-chloride ratio was about 137 to 1 or greater (based on data from lysimeters within the new tailings pile). The reason for this disproportionate ratio is that, during ore processing, sulfate was added to the processing solutions while chloride was not. In contaminated ground water, the proportion of sulfate to chloride is greater than 11 to 1 , up to about 80 to 1 (Figures 3.4 and 3.5).

Based on all indicators of ground water contamination (sulfate, nitrate, uranium, and sulfate-to-chloride ratios), the extent of contamination appears to be within an area delineated by monitor wells $603,604,605,654,652,651$, and 650 , east and north of the site. However, several of these downgradient uncontaminated wells are completed in the deeper portion of the alluvial aquifer, and shallow ground water contamination could theoretically extend further downgradient than is shown in Figure 3.1 (in the area of wells $650,651,652$, and 654). The hydraulic gradient prevents contamination from extending south

of the site, and the depositional limit of the alluvial aquifer corresponds to the western limit of possible contamination in the aquifer (Figures 3.1, 3.2, 3.3 and 3.5).

The vertical distribution of ground water contamination is not fully known. The saturated zone in the alluvial aquifer is from 0 to at least $60 \mathrm{ft}(18 \mathrm{~m})$ thick in the area of ground water contamination. In a few wells near the site, such as wells 603 and 606, the alluvial aquifer is thin. Almost the entire saturated thickness of the alluvial aquifer are screened. Further from the site, where the aquifer is thicker (wells 655, 656, and 653), only the upper 25 to $40 \mathrm{ft}$ ( 8 to $12 \mathrm{~m}$ ) of the saturated thickness of the alluvial aquifer are screened. Still further from the site, in wells 650 and 654 , only the lower 50 to $84 \mathrm{ft}(15$ to $26 \mathrm{~m}$ ) of the saturated thickness of the aquifer are screened. Thus, the lateral and vertical distribution of contamination is not fully characterized in those areas. Northeast of the site, near wells 651 and 652 , most of the saturated thickness is screened. However, the upper 10 to $15 \mathrm{ft}$ ( 3 to $4.5 \mathrm{~m}$ ) of the saturated thickness have not been sampled for ground water contamination. 
Figure 3.4

Comparison of Sulfate to Chloride in the Contaminated

Ground Water (Wells 606 and 655) and in Naturally Saline

Ground Water (Wells 605 and 640), Alluvial Aquifer,

Monument Valley, Arizona, Site

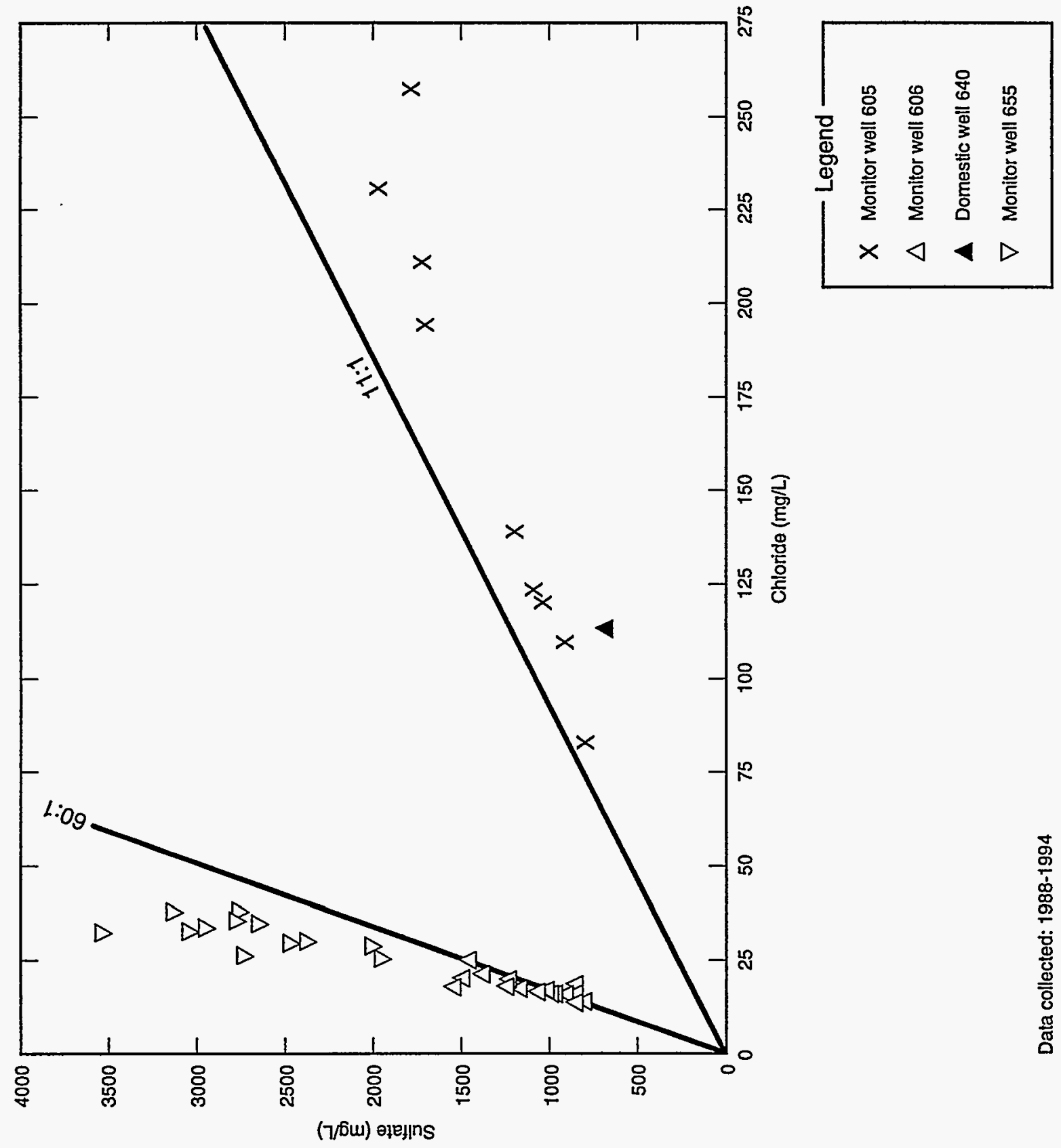


Figure 3.5

Distribution of Sulfate to Chloride Ratios in the

Alluvial Aquifer and Surface Waters

Monument Valley, Arizona, Site

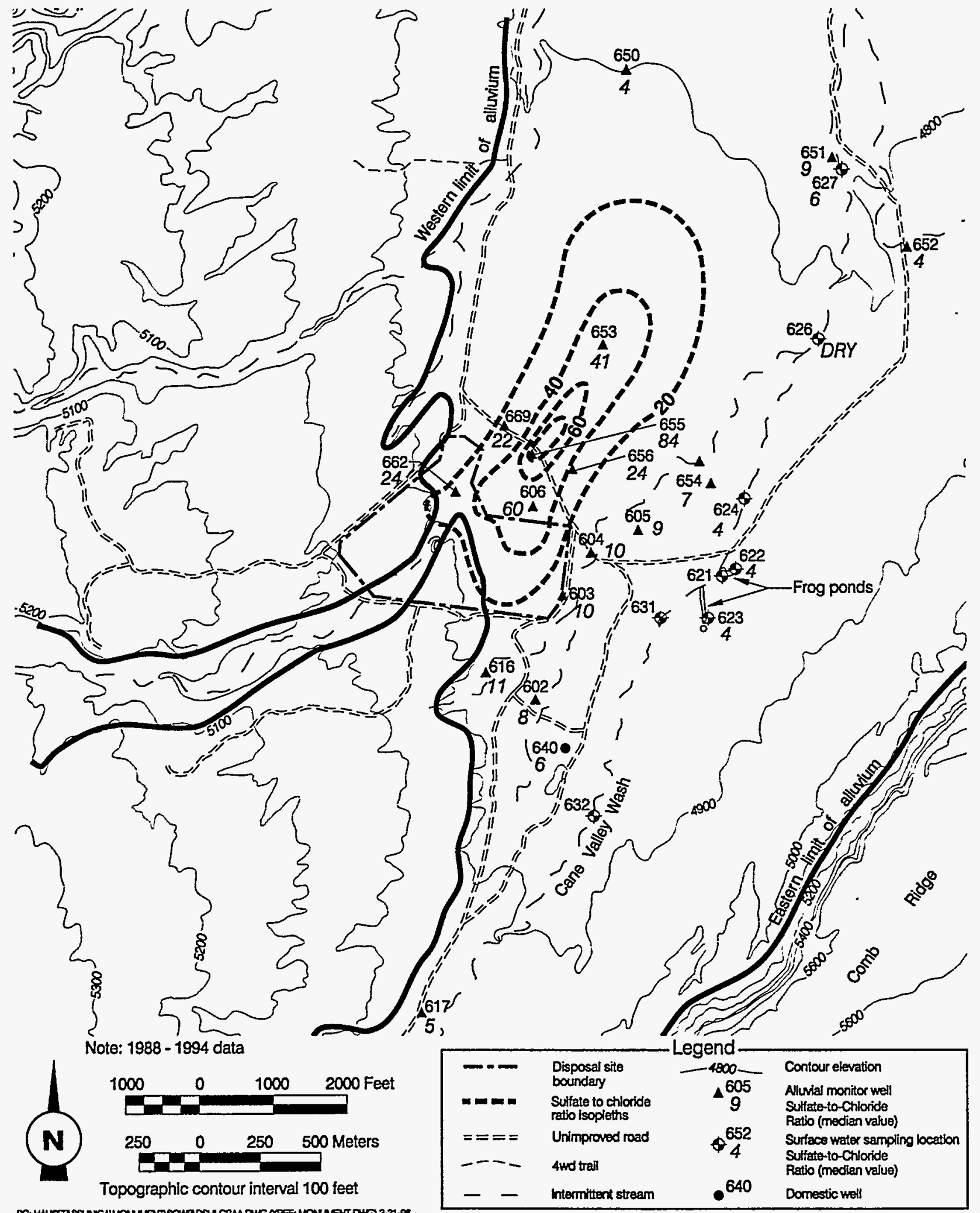

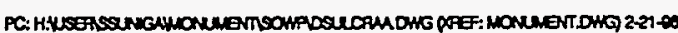




\subsubsection{Ground water contamination in the Shinarump Conglomerate aquifer}

Ground water data collected since 1988 are available from five wells completed in the Shinarump Conglomerate aquifer: 601, 614, 615,659, and 660. Wells 601 and 615 are background wells, while the remainder are downgradient of the site. Of these, only well 614 displays evidence of site-related ground water contamination. In this well, the indicator parameters (calcium, sulfate, and nitrate) are elevated about 2 to 5 times background. Also, sulfate-to-chloride ratios exceed 11 to 1 , suggesting contamination. Uranium is about 6 times background, but the level (median of $0.032 \mathrm{mg} / \mathrm{L}$ ) is still below the UMTRA Project uranium maximum concentration limits (MCL). Table 3.5 compares the median values from this well to background.

Ground water contamination in the Shinarump Conglomerate aquifer at well 614 may be due to cross-formational flow of contaminated ground water from the alluvial aquifer into the upper portion of the Shinarump Conglomerate aquifer. The magnitude of contamination in well 614 , compared to the distribution of contamination in the alluvial aquifer, is consistent with this model. In well 614, the ground water table is essentially at the contact between the alluvial and Shinarump Conglomerate aquifers. Therefore, the contaminated ground water would have to flow laterally (from the southeast) rather than vertically into the Shinarump at this point.

The two Shinarump wells (660 and 659) immediately beneath the contaminated plume within the alluvial aquifer do not show evidence of ground water contamination.

\subsubsection{Ground water contamination in the De Chelly Sandstone aquifer}

Two wells within the De Chelly Sandstone aquifer (619 and 657) show the influence of site-related contamination. In both wells, located within a few hundred feet of each other, concentrations of calcium, nitrate, sulfate, and uranium exceed background concentrations (Table 3.6). Also, sulfate-to-chloride ratios exceed 11 to 1 , consistent with site-related contamination. Both wells are in the area of the site once occupied by the old tailings pile and heap-leach pads. This area is underlain by a $100-\mathrm{ft}(30-\mathrm{m})$-deep buried channel, in bedrock filled with water-transported and windblown sands. The boring log for well 657 indicates the channel has eroded through the Shinarump Conglomerate and Moenkopi Formation such that the alluvial aquifer rests directly upon the De Chelly Sandstone in this area. Also, well 619 was used to provide processing water during milling operations, and water for the tailings removal operations. Pumping this well appears to have drawn contaminated ground water from the alluvial aquifer into the De Chelly Sandstone in this area. No other wells in the De Chelly Sandstone show evidence of site-related ground water contamination.

\subsection{CONSTITUENTS OF POTENTIAL CONCERN}

Of the alluvial, Shinarump Conglomerate, and De Chelly Sandstone aquifers, the alluvial aquifer is the most contaminated at the Monument Valley site (Tables 3.4, 
Table 3.5 Comparison of contaminated ground water to background ground water quality data in the Shinarump Conglomerate aquifer, Monument Valley, Arizona, site

\begin{tabular}{|c|c|c|c|}
\hline Constituent & $\begin{array}{l}\text { MON-01-0601 } \\
\text { (background) }\end{array}$ & $\begin{array}{l}\text { MON-01-0615 } \\
\text { (background) }\end{array}$ & $\begin{array}{c}\text { MON-01-0614 } \\
\text { (contaminated) }\end{array}$ \\
\hline Alkalinity & 280 & 226 & 189 \\
\hline Aluminum & 0.07 & $<0.1$ & $<0.1$ \\
\hline Ammonium & 0.125 & $<0.1$ & $<0.1$ \\
\hline Antimony & 0.004 & $<0.003$ & $<0.003$ \\
\hline Arsenic & 0.005 & 0.003 & 0.005 \\
\hline Barium & 0.05 & 0.05 & 0.1 \\
\hline Boron & 0.05 & $<0.1$ & $<0.1$ \\
\hline Bromide & $<0.1$ & NA & $<0.1$ \\
\hline Cadmium & $<0.005$ & $<0.001$ & $<0.001$ \\
\hline Calcium & 28.4 & 17.5 & 88.0 \\
\hline Chloride & 15.1 & 9.9 & 20.0 \\
\hline Fluoride & 0.2 & 0.4 & 0.2 \\
\hline Iron & $<0.03$ & 0.13 & $<0.03$ \\
\hline Iron (unfiltered) & 107 & 2.95 & 3.06 \\
\hline Lead & $<0.005$ & $<0.01$ & $<0.01$ \\
\hline Lead 210 & $<2.0$ & $<2.0$ & NA \\
\hline Lead-210 (unfiltered)) & $<2.0$ & 7.2 & NA \\
\hline Magnesium & 18 & 16 & 57 \\
\hline Manganese & 0.005 & 0.005 & $<0.01$ \\
\hline Manganese (unfiltered) & 1.46 & 0.35 & 0.11 \\
\hline Molybdenum & 0.005 & $<0.005$ & $<0.007$ \\
\hline Nitrate as $\mathrm{NO}_{3}$ & 4.25 & 4.3 & 25.2 \\
\hline $\mathrm{pH}$ & 7.79 & 7.84 & 7.59 \\
\hline Phosphate (unfiltered) & 2.6 & $<0.1$ & 1.3 \\
\hline Potassium & 1.9 & 3.1 & 1.8 \\
\hline Radium-226 & 0.3 & 1.2 & 0.5 \\
\hline Radium-228 & 1.4 & 2.7 & 1.0 \\
\hline Redox potential & 442 & 248 & 456 \\
\hline Selenium & 0.005 & $<0.005$ & 0.005 \\
\hline Silica & 14 & 9 & 14 \\
\hline Sodium & 99 & 88 & 31 \\
\hline Strontium & 0.29 & 0.63 & 0.69 \\
\hline
\end{tabular}


Table 3.5 Comparison of contaminated ground water to background ground water quality data in the Shinarump Conglomerate aquifer, Monument Valley, Arizona, site (Concluded)

\begin{tabular}{lccc}
\hline \multicolumn{1}{c}{ Constituent } & $\begin{array}{c}\text { MON-01-0601 } \\
\text { (background) }\end{array}$ & $\begin{array}{c}\text { MON-01-0615 } \\
\text { (background) }\end{array}$ & $\begin{array}{c}\text { MON-01-0614 } \\
\text { (contaminated) }\end{array}$ \\
\hline Sulfate & 125 & 63 & 255 \\
Thorium-230 & $<1.0$ & $\mathrm{NA}$ & $<1.0$ \\
TDS & 429 & 327 & 663 \\
Uranium & 0.005 & 0.001 & 0.032 \\
Vanadium & $<0.025$ & $<0.005$ & $<0.01$ \\
Zinc & 0.0025 & 0.0130 & 0.005 \\
Zinc (unfiltered) & 0.143 & 0.038 & 0.050 \\
\hline
\end{tabular}

Notes:

1. Data listed are median values for filtered samples (except as noted) collected from 1988 through 1994.

2. All data in milligrams per liter (mg/L) except for the following: lead-210, radium-226, radium-228, thorium-230 in picocuries per liter; $\mathrm{pH}$ in standard units; redox potential in millivolts; alkalinity as $\mathrm{mg} / \mathrm{L}$ calcium carbonate equivalent.

3. < indicates less than the given value.

4. NA = not analyzed.

5. The following were not detected in filtered ground water samples (method detection limit is given in parentheses): beryllium $(0.005)$, cadmium $(0.001)$, chromium $(0.01)$, cobalt (0.05), copper (0.02), mercury (0.0002), nickel (0.04), silver (0.01), thallium (0.01), and tin (0.005). 
Table 3.6 Comparison of contaminated ground water to background ground water quality data in the De Chelly Sandstone aquifer, Monument Valley, Arizona, site

\begin{tabular}{|c|c|c|c|c|}
\hline Constituent & $\begin{array}{l}\text { MON-01-0612 } \\
\text { (background) }\end{array}$ & $\begin{array}{l}\text { MON-01-0613 } \\
\text { (background) }\end{array}$ & $\begin{array}{c}\text { MON-01-0619 } \\
\text { (contaminated) }\end{array}$ & $\begin{array}{l}\text { MON-01-0657 } \\
\text { (contaminated) }\end{array}$ \\
\hline Alkalinity & 121 & 185 & 189 & 193 \\
\hline Aluminum & NA & $<0.1$ & NA & NA \\
\hline Ammonium & $<0.1$ & $<0.1$ & $<0.1$ & $<0.1$ \\
\hline Antimony & NA & $<0.003$ & $<0.003$ & $<0.003$ \\
\hline Arsenic & 0.01 & $<0.005$ & $<0.005$ & 0.005 \\
\hline Barium & NA & 0.05 & $<0.1$ & 0.20 \\
\hline Boron & NA & $<0.05$ & NA & $<0.1$ \\
\hline Bromide & NA & $<0.1$ & NA & $<0.1$ \\
\hline Cadmium & 0.004 & $<0.005$ & NA & 0.001 \\
\hline Calcium & 28 & 16 & 56 & 64 \\
\hline Chloride & 6 & 8 & 7 & 8 \\
\hline Fluoride & NA & 0.3 & NA & 0.2 \\
\hline Iron & NA & $<0.03$ & $<0.03$ & $<0.03$ \\
\hline Iron (unfiltered) & NA & 0.04 & $<0.03$ & 0.06 \\
\hline Lead 210 & NA & $<2.0$ & $<2.0$ & $<2.0$ \\
\hline Lead-210 (unfiltered)) & NA & 5.8 & NA & NA \\
\hline Magnesium & 18 & 29 & 32 & 41 \\
\hline Manganese & NA & $<0.005$ & $<0.01$ & $<0.01$ \\
\hline Manganese (unfiltered) & NA & $<0.005$ & $<0.01$ & $<0.01$ \\
\hline Molybdenum & 0.01 & 0.005 & 0.03 & $<0.01$ \\
\hline Nitrate, as $\mathrm{NO}_{3}$ & 8.0 & 4.3 & 20 & 20 \\
\hline $\mathrm{pH}$ & 7.64 & 8.01 & 7.20 & 7.39 \\
\hline Phosphate (unfiltered) & NA & $<0.1$ & $<0.1$ & $<0.1$ \\
\hline Potassium & 5.3 & 2.8 & 2.0 & 1.8 \\
\hline Radium-226 & NA & 0.3 & NA & $<1.0$ \\
\hline Radium-228 & NA & $<1.0$ & NA & $<1.0$ \\
\hline Redox potential & NA & 447 & 447 & 431 \\
\hline Selenium & $<0.005$ & 0.0025 & NA & $<0.005$ \\
\hline Silica & NA & 11 & 13 & 14 \\
\hline Sodium & 13 & 50 & 22 & 15 \\
\hline Strontium & NA & 0.35 & 0.45 & 0.51 \\
\hline Sulfate & 20 & 61 & 73 & 127 \\
\hline
\end{tabular}


Table 3.6 Comparison of contaminated ground water to background ground water quality data in the De Chelly Sandstone aquifer, Monument Valley, Arizona, site (Concluded)

\begin{tabular}{lcccc}
\hline \multicolumn{1}{c}{ Constituent } & $\begin{array}{c}\text { MON-01-0612 } \\
\text { (background) }\end{array}$ & $\begin{array}{c}\text { MON-01-0613 } \\
\text { (background) }\end{array}$ & $\begin{array}{c}\text { MON-01-0619 } \\
\text { (contaminated) }\end{array}$ & $\begin{array}{c}\text { MON-01-0657 } \\
\text { (contaminated) }\end{array}$ \\
\hline Thorium-230 & NA & $<1.0$ & NA & $<1.0$ \\
TDS & 195 & 289 & 320 & 335 \\
Uranium & 0.010 & 0.004 & 0.134 & 0.064 \\
Vanadium & NA & 0.005 & 0.02 & 0.06 \\
Zinc & NA & 0.003 & 0.105 & $<0.005$ \\
Zinc (unfiltered) & NA & 0.005 & 0.035 & 0.197 \\
\hline
\end{tabular}

Notes:

1. Data listed are median values for samples collected from 1988 through 1994.

2. All data in milligrams per liter ( $\mathrm{mg} / \mathrm{L}$ ) except for the following: lead-210, radium-226, radium-228, thorium-230 in picocuries per liter; $\mathrm{pH}$ in standard units; redox potential in millivolts; alkalinity as $\mathrm{mg} / \mathrm{L}$ calcium carbonate equivalent.

3. < indicates less than the given value.

4. NA = not analyzed.

5. The following were not detected in filtered ground water samples (method detection limit is given in parentheses): beryllium (0.005), cadmium (0.001), chromium (0.01), cobalt (0.05), copper (0.02 mg/L), lead (0.005), mercury (0.0002), nickel (0.04), silver (0.01), thallium (0.01), and tin (0.005). 
3.5, and 3.6). Because the Shinarump Conglomerate is closely associated with the alluvial aquifer in terms of contamination, it is not evaluated separately in this assessment. The results of the risk assessment for the alluvial aquifer will be assumed to also represent the Shinarump Conglomerate. However, the highest concentration of uranium detected $(0.13 \mathrm{mg} / \mathrm{L})$ is in the De Chelly Sandstone aquifer. Therefore, this detected value of uranium in the De Chelly aquifer is considered when selecting constituents of potential concern instead of the lower values detected in the alluvial or Shinarump Conglomerate aquifers.

The data discussed in Sections 3.1 and 3.2 were used to compile a list of constituents of potential concern for the assessment of human health or environmental risks at the Monument Valley site. In general, a constituent was placed on the list of constituents of potential concern if concentrations in ground water samples from the most contaminated alluvial well (655 or 606), on average exceed background levels (DOE, 1996b), and if the site is a likely cause of exceedance (Table 3.7). Although some constituents, not identified as exceeding background, have either median or maximum values in downgradient wells that exceed background (e.g., arsenic, bromide, and selenium), the difference between background and downgradient data was not large enough or consistent enough to reach statistical significance at the 0.05 level. Constituents that exceed background levels are presented in column 1 of Table 3.8.

These constituents were screened for their impact on human health, using the criteria discussed below to develop a final list of constituents of potential concern for human health (DOE, 1996b). Several constituents detected above background were deleted from the final list of constituents of potential concern because they are essential nutrients whose detected levels are within nutritional ranges. These constituents include chloride, iron, and potassium. Final screening of the remaining constituents was based on very low toxicity and relatively high normal dietary intake compared to the values detected. These criterion ruled out ammonium, calcium, magnesium, and sodium.

Although ammonium is not considered a dietary component, it is produced in the human body at levels exceeding $4000 \mathrm{mg}$ per day (Summerskill and Wolpert, 1970), roughly an order of magnitude more than would result from ingestion of the most ammonium-contaminated water at the site $(381 \mathrm{mg} / \mathrm{L})$. Although detected levels are substantially higher than background, they will not likely be associated with adverse health effects and ammonium is not retained as a constituent of potential concern. However, detected concentrations will likely affect the taste and odor of the water.

Screening based on the criteria described above eliminated all of the site-related constituents from consideration except manganese, nitrate, strontium, sulfate, uranium, and vanadium. These constituents of potential concern are evaluated in this risk assessment for their potential to cause adverse human health effects.

Of the final constituents of potential concern, strontium, sulfate, and uranium are also elevated in private well 640 . Nitrate and vanadium levels are not above background in this well nor are the plume indicators, ammonium, manganese, and potassium. As discussed in Section 3.2, well 640 has not been affected by the siterelated contaminant plume. However, sulfate and uranium levels in this well will be 


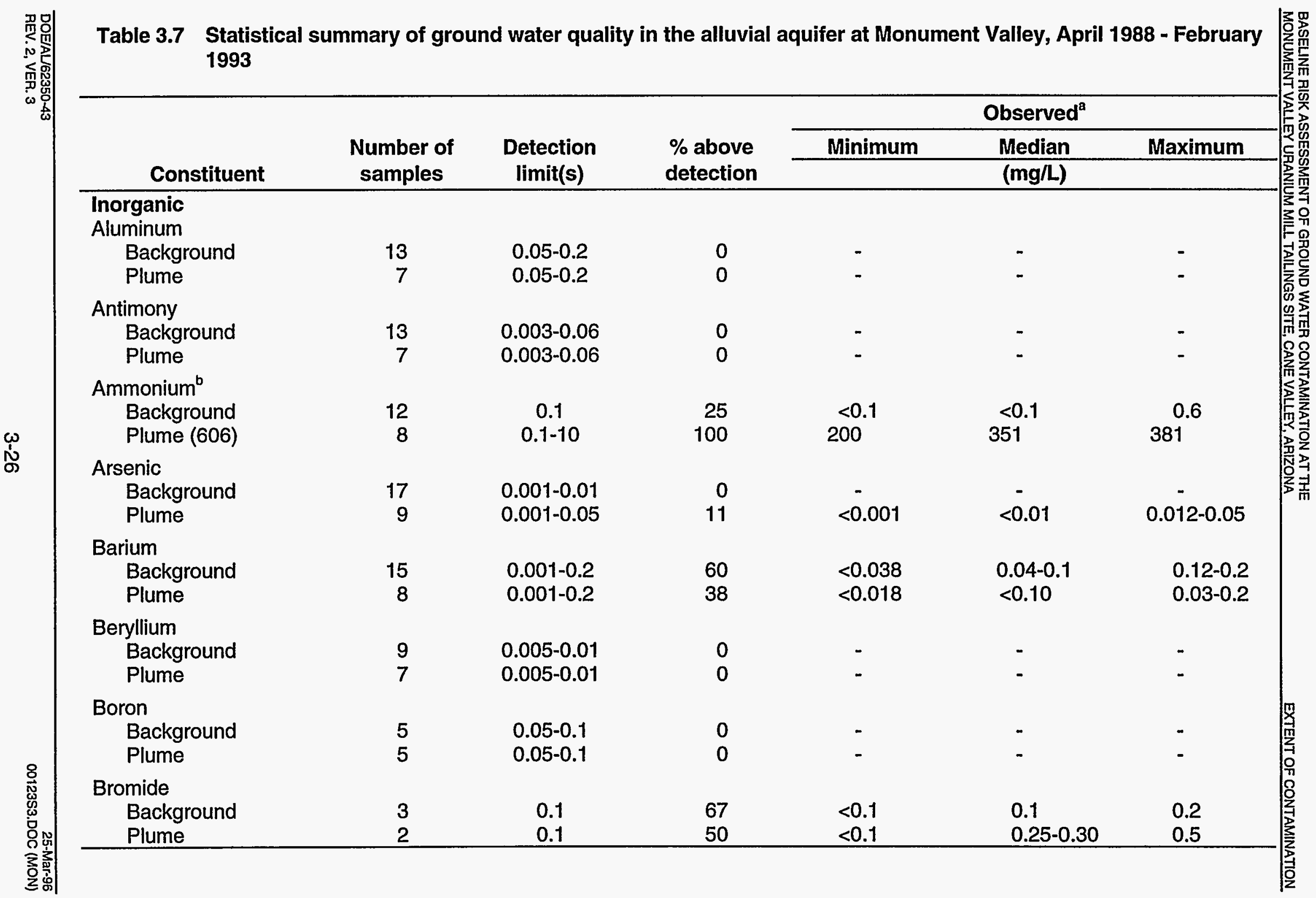


Table 3.7 Statistical summary of ground water quality in the alluvial aquifer at Monument Valley, April 1988 - February 1993 (Continued)

\begin{tabular}{|c|c|c|c|c|c|c|}
\hline \multirow[b]{2}{*}{ Constituent } & \multirow[b]{2}{*}{$\begin{array}{l}\text { Number of } \\
\text { samples }\end{array}$} & \multirow[b]{2}{*}{$\begin{array}{l}\text { Detection } \\
\text { limit(s) }\end{array}$} & \multirow[b]{2}{*}{$\begin{array}{l}\% \text { above } \\
\text { detection }\end{array}$} & \multicolumn{3}{|c|}{ Observed $^{\mathrm{a}}$} \\
\hline & & & & Minimum & $\begin{array}{l}\text { Median } \\
\text { (mg/L) }\end{array}$ & Maximum \\
\hline $\begin{array}{l}\text { Cadmium } \\
\text { Background } \\
\text { Plume }\end{array}$ & $\begin{array}{r}17 \\
9\end{array}$ & $\begin{array}{l}0.0001-0.005 \\
0.0001-0.005\end{array}$ & $\begin{array}{l}12 \\
11\end{array}$ & $\begin{array}{l}<0.0001 \\
<0.0001\end{array}$ & $\begin{array}{l}<0.001 \\
<0.001\end{array}$ & $\begin{array}{l}0.005 \\
0.03\end{array}$ \\
\hline $\begin{array}{l}\text { Calcium } \\
\text { Background } \\
\text { Plume }\end{array}$ & $\begin{array}{r}16 \\
9\end{array}$ & $\begin{array}{l}0.01-5 \\
0.01-5\end{array}$ & $\begin{array}{l}100 \\
100\end{array}$ & $\begin{array}{r}18 \\
372\end{array}$ & $\begin{array}{r}27 \\
411\end{array}$ & $\begin{array}{r}37 \\
521\end{array}$ \\
\hline $\begin{array}{l}\text { Chloride }^{\mathfrak{b}} \\
\text { Background } \\
\text { Plume }\end{array}$ & $\begin{array}{r}16 \\
9\end{array}$ & $\begin{array}{l}0.02-1 \\
0.02-1\end{array}$ & $\begin{array}{l}100 \\
100\end{array}$ & $\begin{array}{l}10 \\
29\end{array}$ & $\begin{array}{l}14 \\
33\end{array}$ & $\begin{array}{l}17 \\
38\end{array}$ \\
\hline $\begin{array}{l}\text { Chromium } \\
\text { Background } \\
\text { Plume }\end{array}$ & $\begin{array}{r}15 \\
8\end{array}$ & $\begin{array}{l}0.005-0.01 \\
0.005-0.01\end{array}$ & $\begin{array}{l}0 \\
0\end{array}$ & - & - & - \\
\hline $\begin{array}{l}\text { Cobalt } \\
\text { Background } \\
\text { Plume }\end{array}$ & $\begin{array}{l}5 \\
5\end{array}$ & $\begin{array}{l}0.03-0.05 \\
0.03-0.05\end{array}$ & $\begin{array}{l}0 \\
0\end{array}$ & - & - & - \\
\hline $\begin{array}{l}\text { Copper } \\
\text { Background } \\
\text { Plume }\end{array}$ & $\begin{array}{l}5 \\
5\end{array}$ & $\begin{array}{l}0.01-0.02 \\
0.01-0.02\end{array}$ & $\begin{array}{r}0 \\
20\end{array}$ & $<0.01$ & $<0.02$ & $\overline{0.02}$ \\
\hline $\begin{array}{l}\text { Cyanide } \\
\text { Background } \\
\text { Plume }\end{array}$ & $\begin{array}{l}2 \\
2\end{array}$ & $\begin{array}{l}0.01 \\
0.01\end{array}$ & $\begin{array}{l}0 \\
0\end{array}$ & - & - & - \\
\hline $\begin{array}{l}\text { Fluoride } \\
\text { Background } \\
\text { Plume }\end{array}$ & $\begin{array}{l}5 \\
5\end{array}$ & $\begin{array}{l}0.1 \\
0.1\end{array}$ & $\begin{array}{l}100 \\
100\end{array}$ & $\begin{array}{l}0.1 \\
0.1\end{array}$ & $\begin{array}{l}0.2 \\
0.1\end{array}$ & $\begin{array}{l}0.3 \\
0.2\end{array}$ \\
\hline
\end{tabular}




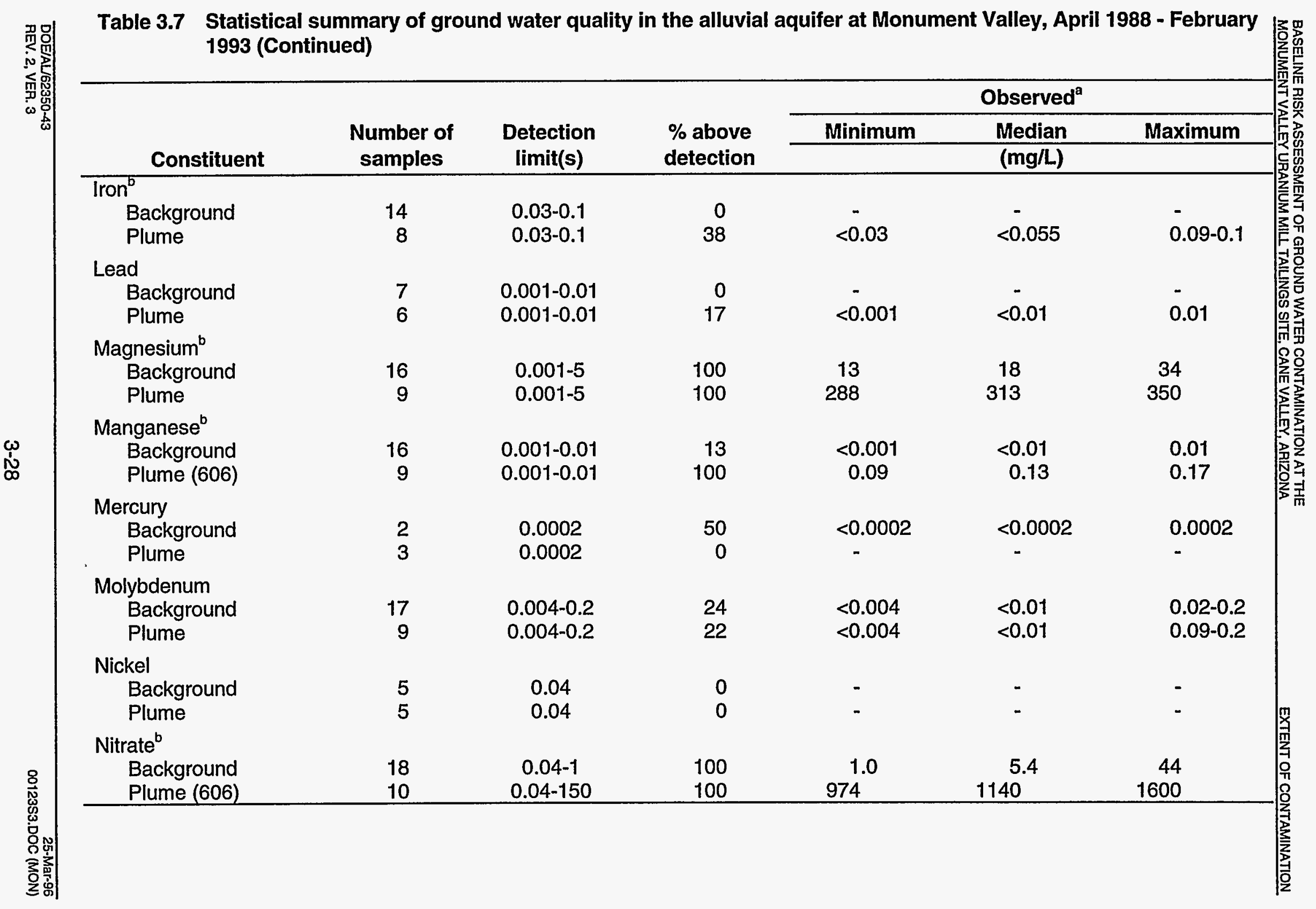




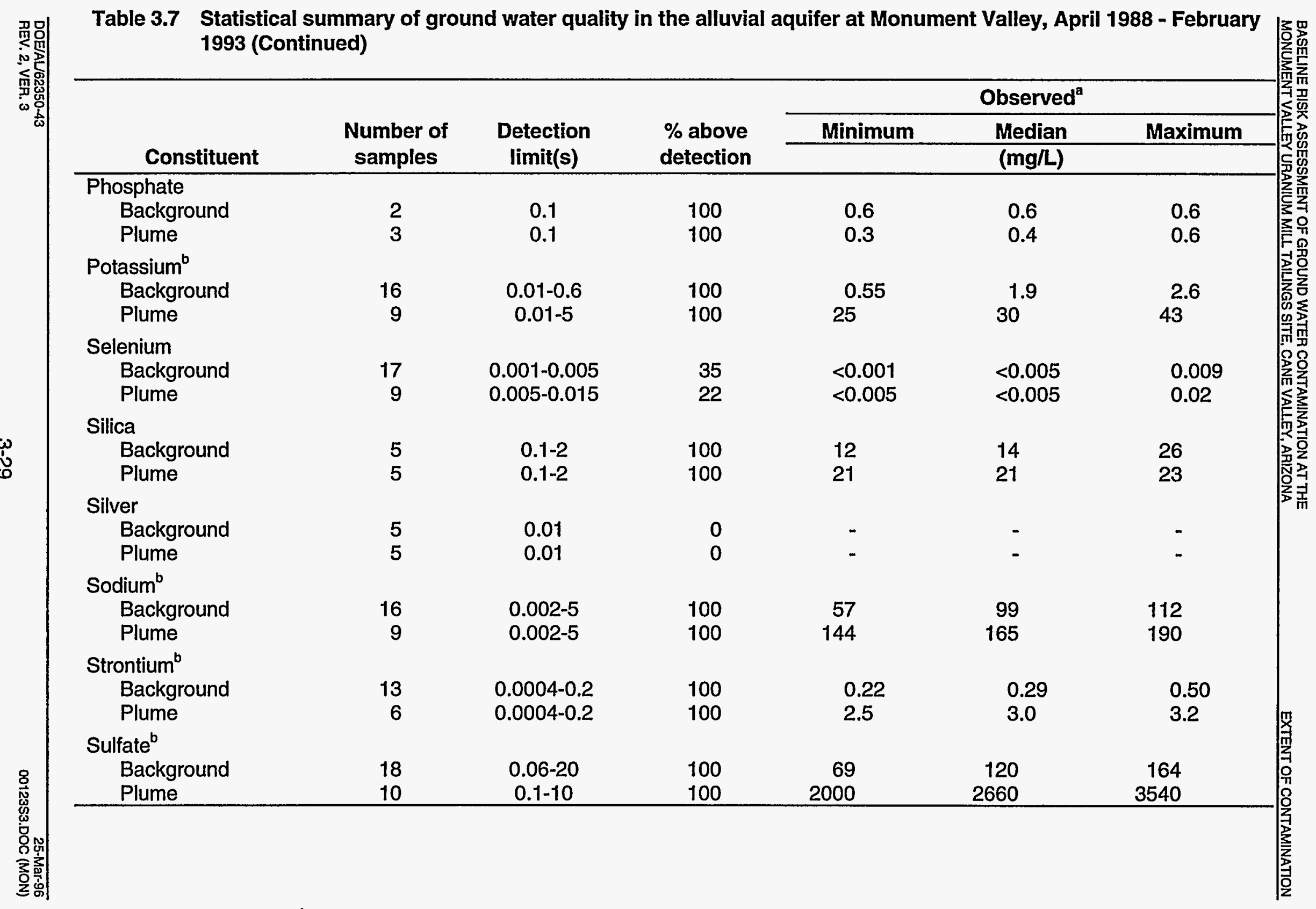




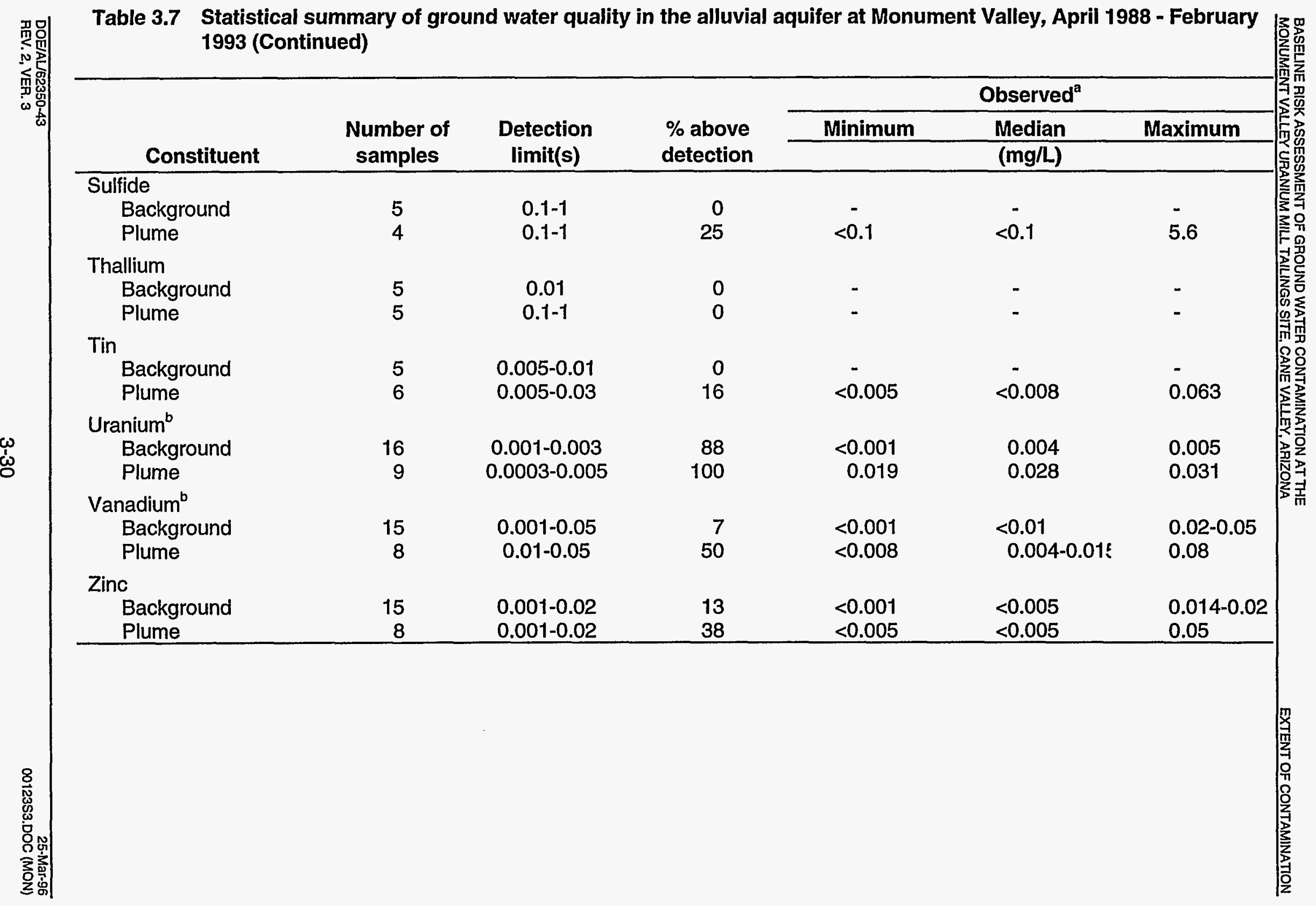




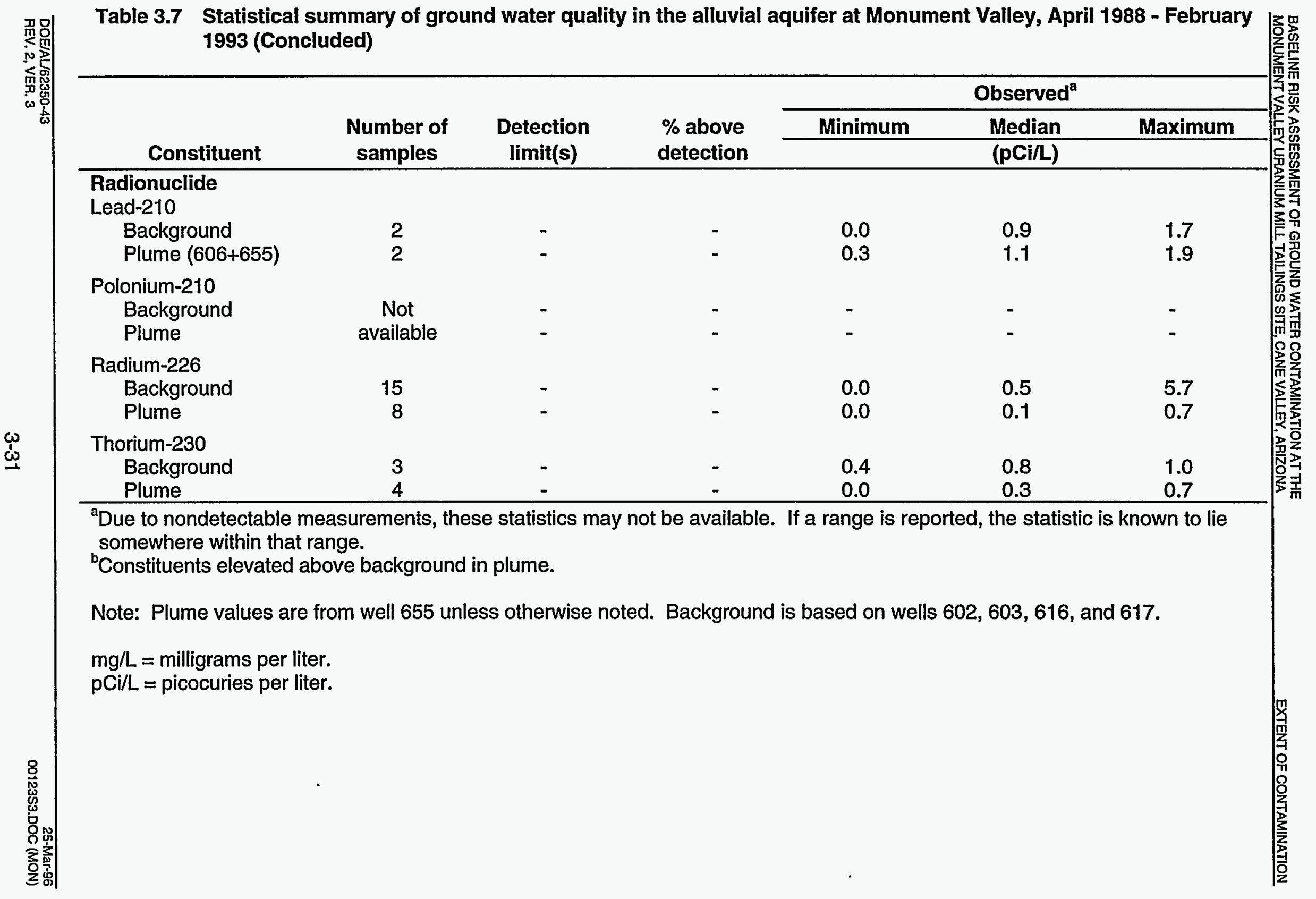


Table 3.8 Constituents of potential concern for human health evaluation

\begin{tabular}{llll}
\hline $\begin{array}{c}\text { Constituent levels } \\
\text { that exceed } \\
\text { background }\end{array}$ & $\begin{array}{c}\text { Constituent levels in } \\
\text { nutritional range }\end{array}$ & $\begin{array}{c}\text { Constituents of low } \\
\text { toxicity and/or high } \\
\text { dietary range }\end{array}$ & $\begin{array}{c}\text { Constituents of } \\
\text { potential } \\
\text { concern } \\
\text { (human health) }\end{array}$ \\
\hline $\begin{array}{l}\text { Ammonium } \\
\text { Calcium }\end{array}$ & $\begin{array}{c}\text { Ammonium } \\
\text { Calcium }\end{array}$ & \\
$\begin{array}{l}\text { Chloride } \\
\text { Iron }\end{array}$ & Chloride & Magnesium & \\
$\begin{array}{l}\text { Magnesium } \\
\text { Manganese }\end{array}$ & Iron & & Manganese \\
Nitrate & Potassium & Nitrate \\
Potassium & & \\
Sodium & Sodium & Strontium \\
Strontium & & Sulfate \\
Sulfate & & Uranium \\
Uranium & & Vandium \\
Vandium & & & \\
\hline
\end{tabular}


evaluated in this document (Section 6) because of the potential public health impact from using the water in this well.

Because ecological impacts differ from effects on human health, the complete list of constituents that statistically exceed background concentrations are considered for the ecological risk assessment in Section 7.0.

\subsection{CONTAMINANT FATE AND TRANSPORT}

Hazardous constituents in the plume waters will be subject to dilution, radioactive decay, and various chemical reactions including redox reactions, precipitation and coprecipitation reactions, adsorption onto aquifer mineral surfaces, and possibly transformation by organisms. Dilution, precipitation reactions, and sorption (e.g., ion exchange) reactions will control concentrations of the dominantly cationic metals such as strontium and the major cations (calcium, magnesium, potassium, and sodium). These processes also will control manganese and zinc concentrations. Only dilution will affect chloride concentrations.

Dilution and adsorption will be the main mechanisms for decreasing uranium and vanadium concentrations. Ion exchange reactions on clays and oxidation to nitrate, perhaps mediated by bacterial action, will decrease ammonium concentrations. These reactions may produce nitrogen, which would be released to the atmosphere.

Sulfate concentrations will be subject to dilution, precipitation/dissolution reactions, adsorption reactions, and possibly redox reactions. The precipitation/dissolution reactions will occur in the portion of the plume closest to the tailings piles.

Precipitation reactions are currently active because the shallow ground water in this zone is oversaturated with gypsum. Now that the tailings piles have been removed, the ground water sulfate concentrations in this zone will decrease, allowing gypsum to redissolve. This dissolution will buffer the sulfate concentrations at fairly high levels until the gypsum is exhausted. At this point, dilution with background waters will substantially lower sulfate concentrations in this zone. Adsorption reactions are not likely to significantly affect sulfate concentrations in the shallow ground water due to the relatively high concentrations involved. Given the high redox potential of the shallow ground water, reduction of sulfate to sulfide also is unlikely.

The chemical species present in natural systems are a function of $\mathrm{pH}$, Eh, and the concentrations of various anions and cations. Speciation determines the mobility of the chemicals and may also influence their toxicity. The predominant species of the constituents of potential of concern for human health were predicted using the geochemical model PHREEQE (Parkhurst et al., 1980). Table 3.9 lists the dominant solution species for the hazardous constituents of potential concern (DOE, 1996b).

\subsection{SURFACE WATER AND SEDIMENT MONITORING}

Figure 2.4 shows the locations of surface water and sediment sampling points. Field observations along Cane Valley Wash are important in interpreting the results of sediment and surface water sampling. In the area of the frog ponds and Cane Valley Wash, north of monitor well 658 (upgradient of the site), the ground water 
Table 3.9 Speciation summary, Monument Valley, Arizona, site

\begin{tabular}{lclc}
\hline $\begin{array}{c}\text { Constituent of } \\
\text { potential concern }\end{array}$ & $\begin{array}{c}\text { Identity of dominant } \\
\text { species in ground } \\
\text { water }\end{array}$ & \multicolumn{1}{c}{ Common name } & Molar \% \\
\hline Manganese & $\mathrm{Mn}^{2+}$ & Manganese & 64 \\
Nitrate & $\mathrm{MnS}_{4 \mathrm{AQ}}$ & Manganese sulfate & 31 \\
Strontium & $\mathrm{NO}_{3}^{-}$ & Nitrate & 100 \\
Sulfur & $\mathrm{Sr}^{2+}$ & Strontium & 100 \\
Uranium & $\mathrm{SO}_{4}{ }^{2-}$ & Sulfate & 100 \\
& $\mathrm{UO}_{2}\left(\mathrm{CO}_{3}\right)_{3}^{4-}$ & Uranyl tricarbonate & 70 \\
Vanadium & $\mathrm{UO}_{2}\left(\mathrm{CO}_{3}\right)_{2}^{2-}$ & & 30 \\
& $\mathrm{HV}_{2} \mathrm{O}_{7}{ }^{3-}$ & Pyrovanadic acid & 83 \\
$\mathrm{H}_{2} \mathrm{VO}_{4}^{-}$ & & 15 \\
\hline
\end{tabular}

Note: Assume $\mathrm{Eh}=400 \mathrm{mV} ; \mathrm{pH}=7.0$. 
table in the alluvial aquifer is commonly at or within a few feet of the surface. Capillary action keeps the sediments in the bottom of the wash wet, and evapotranspiration of the capillary water results in the precipitation and accumulation of a 1- to 3-millimeters (mm)-thick crust of salts over much of the surface of the wash. In some areas downstream of the frog ponds, the area covered by salts is more than $300 \mathrm{ft}(100 \mathrm{~m})$ wide. These salts are predominantly sodium carbonate and very soluble. Wind transport of the salts has been observed, inferring that wind erosion and dissolution of the salts during rains prevents the formation of thick salt deposits in the wash.

Natural scour pools in the wash are common and often intersect the ground water table. Except after rains, water in these surface pools is derived from the nearsurface ground water affected by evaporation and transpiration. Thus, the water in the pools along the wash tend to have high TDS, as determined by electrical conductivity measurements in the field.

\subsubsection{Sediment results}

Table 3.10 presents chemical results for sediments collected in 1993. Sediment collected from the northernmost frog pond (location 623) is upgradient from the site and was not identified as a vicinity property. Therefore, location 623 provides sediment background samples. Levels of arsenic, strontium, uranium, vanadium, and zinc are low compared to average concentrations in soils and sediments (Shacklette and Boerngen, 1984), possibly reflecting the sandy, well sorted nature of the sediments derived from windblown sands. Sulfate concentrations are notable and may reflect the accumulation of natural sulfate salts in the sediments due to evaporation and transpiration.

Comparison of sediments in Cane Valley Wash $(624,626$, and 627) indicates two notable differences in chemistry from sediments in the frog ponds area. Zinc at location 627 and arsenic at location 620 are elevated when compared to the frog pond sample; however, more data would be required to determine if these levels of arsenic and zinc are beyond the range of ambient values.

\subsubsection{Surface water results}

Table 3.11 summarizes surface water sampling results. Location 623 serves as a background sample. Locations 621 and 622 are downstream (north) of 623, in a northern frog pond, fed by water from the southern frog pond. As discussed in Section 2.1 , this northern pond was a vicinity property. The banks were stabilized with uranium mineralized rock. The rock was removed during surface remediation. Because water samples from locations 621 and 622 were collected before remediation, some constituents in surface water at these locations could be elevated by the ore rock. However, the hydraulic gradient precludes contamination of the frog ponds by ground water discharge.

Variations in alkalinity, chloride, magnesium, sodium, sulfate, and TDS at sampling locations 621,622 , and 623 are likely due to differences in evaporation and transpiration rates caused by climatic conditions at the time of sampling. For 
Table 3.10 Summary of sediment chemistry data, Monument Valley, Arizona, site

\begin{tabular}{lccccc}
\hline Constituent & $\begin{array}{c}\text { MON-01-0623 } \\
\text { (background) }\end{array}$ & MON-01-0624 & MON-01-0626 & MON-01-0627 & MON-01-0620 \\
\hline Arsenic & 0.9 & 0.6 & 0.8 & 0.9 & 4 \\
Nitrate & 1.8 & 3.8 & 0.4 & 0.9 & 0.9 \\
Strontium & 116 & 46 & 26 & 54 & 28 \\
Sulfate & 771 & 935 & 42 & 35 & 48 \\
Uranium & $<1.0$ & $<1.0$ & $<1.0$ & $<1.0$ & 1.0 \\
Vanadium & 6 & 3 & 5 & 9 & 9.0 \\
Zinc & 10.7 & 10.8 & 6.8 & 29.2 & 18.7 \\
\hline
\end{tabular}

Notes:

1. Samples collected June 1993.

2. All data in milligrams per kilogram.

3. < indicates less than the given value. 


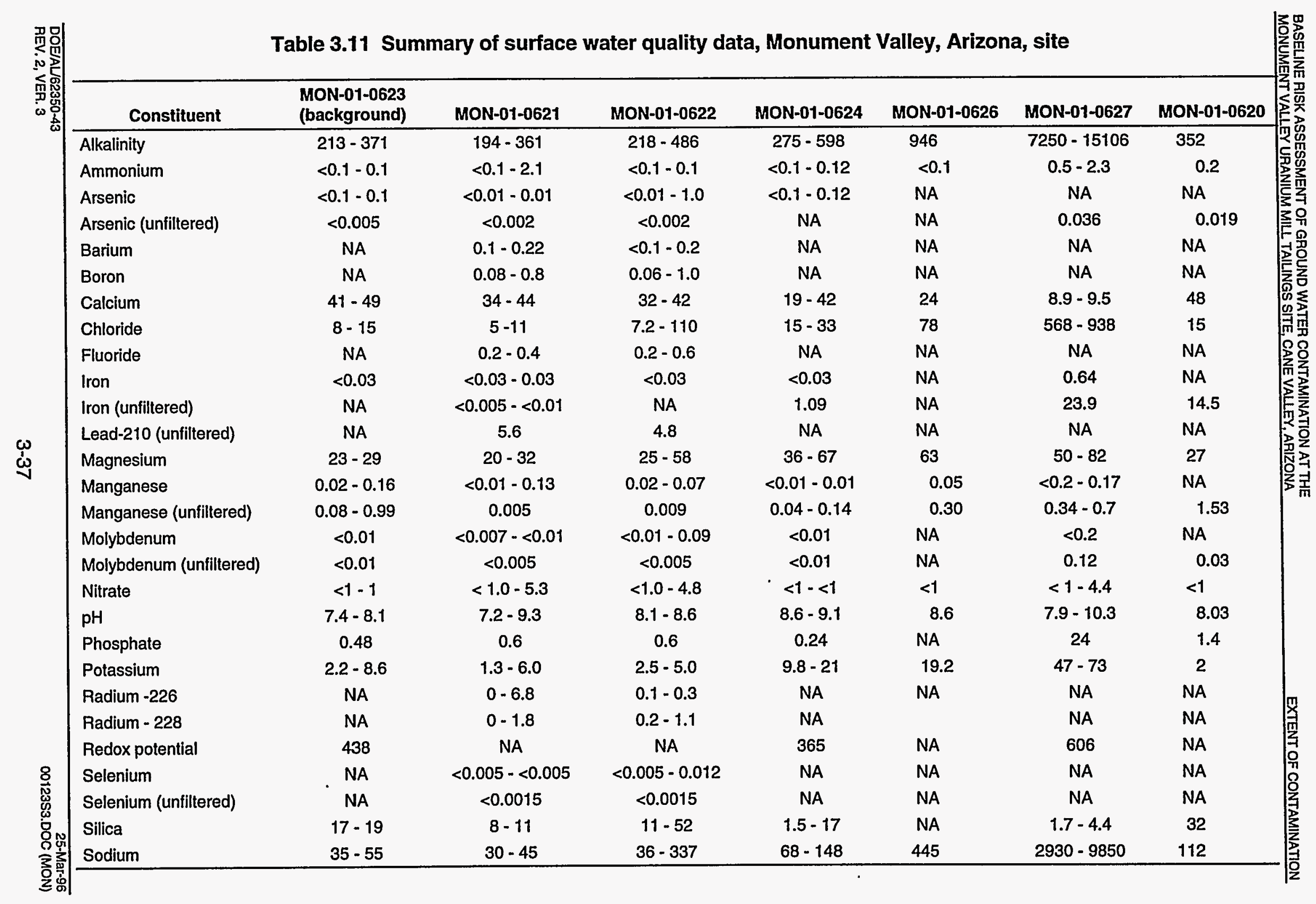




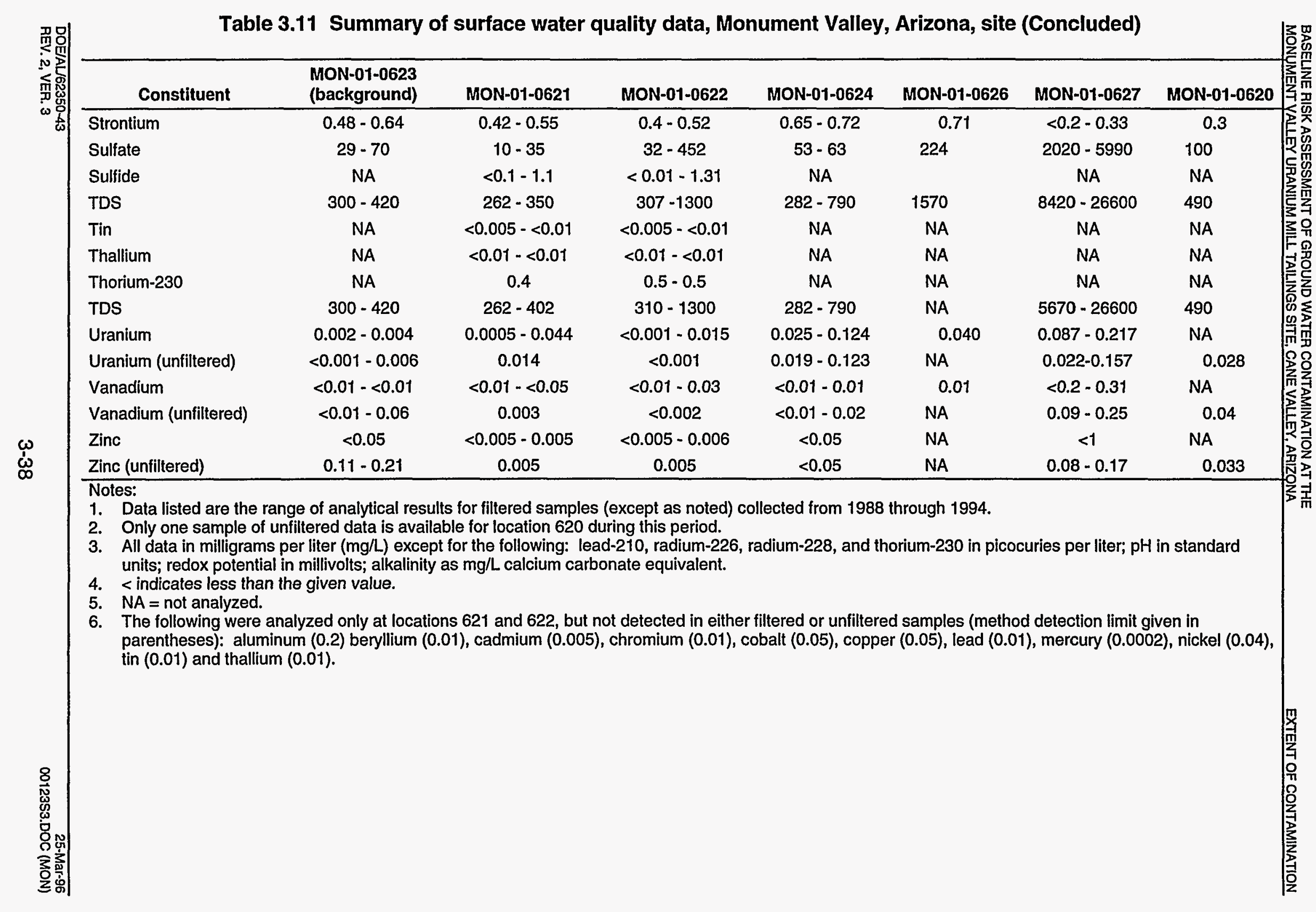


example, chloride concentrations vary from 5 to $172 \mathrm{mg} / \mathrm{L}$ while sulfate varies from 10 to $452 \mathrm{mg} / \mathrm{L}$ in the same locations sampled at different times. The sulfate-tochloride ratio tends to remain the same during evaporative concentration (provided saturation with sulfate salts is not reached, as is the case with the sampled surface waters). In the background surface water samples, the sulfate-to-chloride ratio is about 4 to 1. Likewise, in samples from locations 621 and 622 , the sulfate-tochloride ratios also are about 4 to 1, regardless of the sulfate concentration (Figure 3.5). Thus, variations in most constituents in these samples are due to varying amounts of evaporative and transpirative concentration. This also may be true of uranium and molybdenum. However, the former presence of ore rock in the northern pond is another possible source of ore uranium and molybdenum.

Surface and near-surface water quality data from Cane Valley Wash also indicate evaporation and transpiration of natural (uncontaminated) ground water discharge to the wash are affecting water quality. Samples collected from location 627 best demonstrate this. Water collected at this location is sodium-carbonate water, with dissolved carbonate concentrations of up to $15,100 \mathrm{mg} / \mathrm{L}$. This high carbonate concentration is the expected result of evaporation of sodium bicarbonate water, such as characterizes background water in the area. By contrast, the contaminated ground water does not have elevated concentrations of bicarbonate or carbonate. Further, it can be demonstrated that evaporation of a calcium sulfate water, such as the contaminated ground water at the site, would lead to a saline water containing little or no carbonate (Drever, 1982). Thus, the high TDS near-surface water is not related to contaminated ground water discharge to Cane Valley Wash. The conditions listed below support this conclusion.

- Chloride concentrations much higher than those found in contaminated ground water.

- Sulfate to chloride ratios of about 5 to 1 (Figure 3.5 and 3.6), consistent with an evaporative concentration of natural ground water discharge rather than discharge of contaminated ground water.

- The relatively low concentration of indicators of ground water contamination other than sulfate, including calcium, nitrate, and ammonium.

Thus, it is clear that the variations in most, if not all, constituent concentrations in Cane Valley Wash are due to varying rates of evaporation and transpiration and ground water discharge. Chloride concentrations suggest that evaporation may concentrate natural constituents in near-surface waters by a factor of 60 or more. Given that the background ground water discharging to the wash contains up to $0.006 \mathrm{mg} / \mathrm{L}$ of uranium, it is reasonable to expect uranium concentrations of more than $0.36 \mathrm{mg} / \mathrm{L}$ in evaporated surface water. This is especially true because uranium is very soluble and stable in the presence of dissolved carbonate. The available data do not completely rule out the possibility that at least some uranium, molybdenum, and vanadium in the wash are derived from ore rock and tailings used to construct haul-road crossings over the wash and its tributaries. This possibility, however, is not supported by the available sediment data discussed above. 
Figure 3.6

Sulfate to Chloride Ratios in Surface Water in the

Frog Ponds (Location 623) and Cane Valley Wash (Locations 624 and 627)

Monument Valley, Arizona, Site

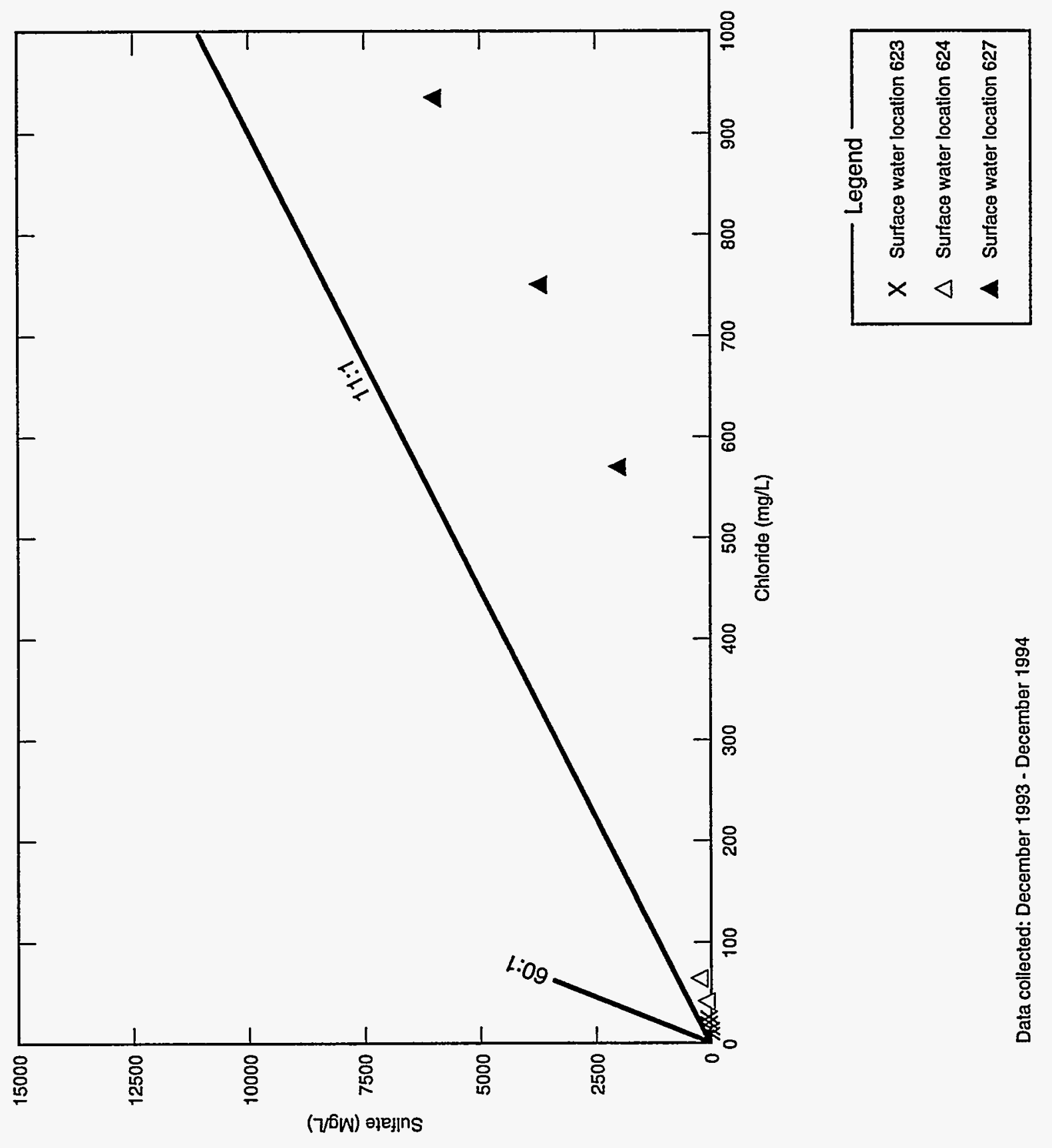


Surface water data were collected once since 1988, from a spring (location 620) $2 \mathrm{mi}(3.2 \mathrm{~km})$ downgradient of the site. This spring is on a tributary to Cane

Valley Wash. Water quality data are similar to those of the frog ponds and do not show evidence of contaminated ground water discharge. Uranium, vanadium, and molybdenum levels from the spring are elevated when compared to location 623 (the frog ponds). Because of the vicinity property (haul-road crossing) upstream of the sampling location, it cannot be determined if these three ore-related elements occur naturally or are due to uranium ore rock washed down the stream.

\subsection{SUMMARY}

In summary, background ground water is generally a sodium-bicarbonate type having relatively low TDS. Contaminated ground water has relatively high TDS and is a calcium-sulfate type with varying amounts of nitrate and ammonia. The contaminated ground water has a high sulfate to chloride ratio of up to approximately 80 to 1. Contaminated ground water occurs primarily in the alluvial aquifer in areas west of Cane Valley Wash and downgradient of the former processing site. Contaminated ground water also occurs in relatively small portions of the Shinarump Conglomerate and the De Chelly Sandstone. Constituents that exceed background levels in the alluvial aquifer are ammonium, calcium, chloride, iron, magnesium, manganese, nitrate, potassium, silica, sodium, strontium, sulfate, uranium, and vanadium.

Surface water along Cane Valley Wash and in two shallow wells upgradient and cross gradient of the site have high TDS concentrations that appear to be due to discharge and evaporation of the natural ground water (i.e., ground water that has not been affected by the contaminant plume). This evaporation of ground water produces sodium carbonate surface water. While TDS values increase during evaporation, the sulfate-to-chloride ratio remains relatively constant at a proportion of 11 to 1 or less. These characteristics differentiate the contaminated ground water from natural, evaporatively concentrated water. The evaporative concentration of natural uranium in ground water may explain the relatively high concentrations of uranium in some saline surface waters along the wash. However, the use of ore rock to make stream-crossings may have also contributed to uranium in the surface waters (though sediment data do not support this), and the source of uranium in saline surface water remains uncertain. However, based on the current knowledge of the site, contaminated ground water is not discharging to Cane Valley Wash. 



\subsection{EXPOSURE ASSESSMENT}

\subsection{POTENTIALLY EXPOSED POPULATIONS AND EXPOSURE PATHWAYS}

Exposure can occur only if there is a source of contamination and a mechanism of transport to a receptor population or individual. Ground water contaminated by uranium processing at the Monument Valley site is not currently used by the Navajo people for domestic or agricultural purposes (refer to Section 2.5). Because there are no known current human receptors of contaminated ground water, future ground water use scenarios are assessed. These scenarios evaluate domestic and agricultural ground water use consistent with current ground water use by the regional rural population. Figure 4.1 provides a conceptual model of potential exposure pathways for the Monument Valley site.

Ground water is the sole source of water in the vicinity of the site. Since access to the contaminated ground water is not restricted, there is a potential that Navajo people living in the area could construct a well and use the contaminated ground water for domestic purposes such as drinking, cooking, and bathing, thereby being exposed to site-related constituents through drinking water and dermal absorption. Additionally, the ground water could be used for agricultural purposes including irrigating gardens and watering livestock, and site-related constituents could accumulate in garden produce and in meat and milk of livestock and be ingested by people.

Furthermore, native plants with roots accessing the contaminated ground water could also uptake and bioaccumulate site-related constituents. The Navajo people use many of the native plants, identified in the area of the site, for cultural purposes. Some of these purposes include medicinal and decorative uses, food, and traditional ceremonial uses. People could be exposed if the roots of any of the plants used access the contaminated ground water and bioaccumulate site-related constituents at levels that could be harmful if ingested or inhaled. However, because no sitespecific plant uptake data are available and there are limited plant uptake data in the literature, the potential risks due to the ingestion (e.g., teas, medicines) or inhalation (burning) of plants are not evaluated in this risk assessment.

The assessment of background water quality and the hydrogeologic system for the Monument Valley site area indicates the private wells south and crossgradient of the site have not been affected by contaminated ground water and are not expected to be affected in the future. As discussed in Section 3.3, well 640 has elevated levels of sulfate, strontium, and uranium, in comparison to background, but is not affected by the contaminant plume. Nevertheless, as a public health concern, the potential health risks from drinking ground water from this well are evaluated in Section 6.0.

\subsubsection{Drinking water ingestion}

Drinking water ingestion is generally the most significant exposure pathway for ground water contaminated with metals and other nonvolatile compounds. For this evaluation, drinking water consumption includes water used for drinking and water 


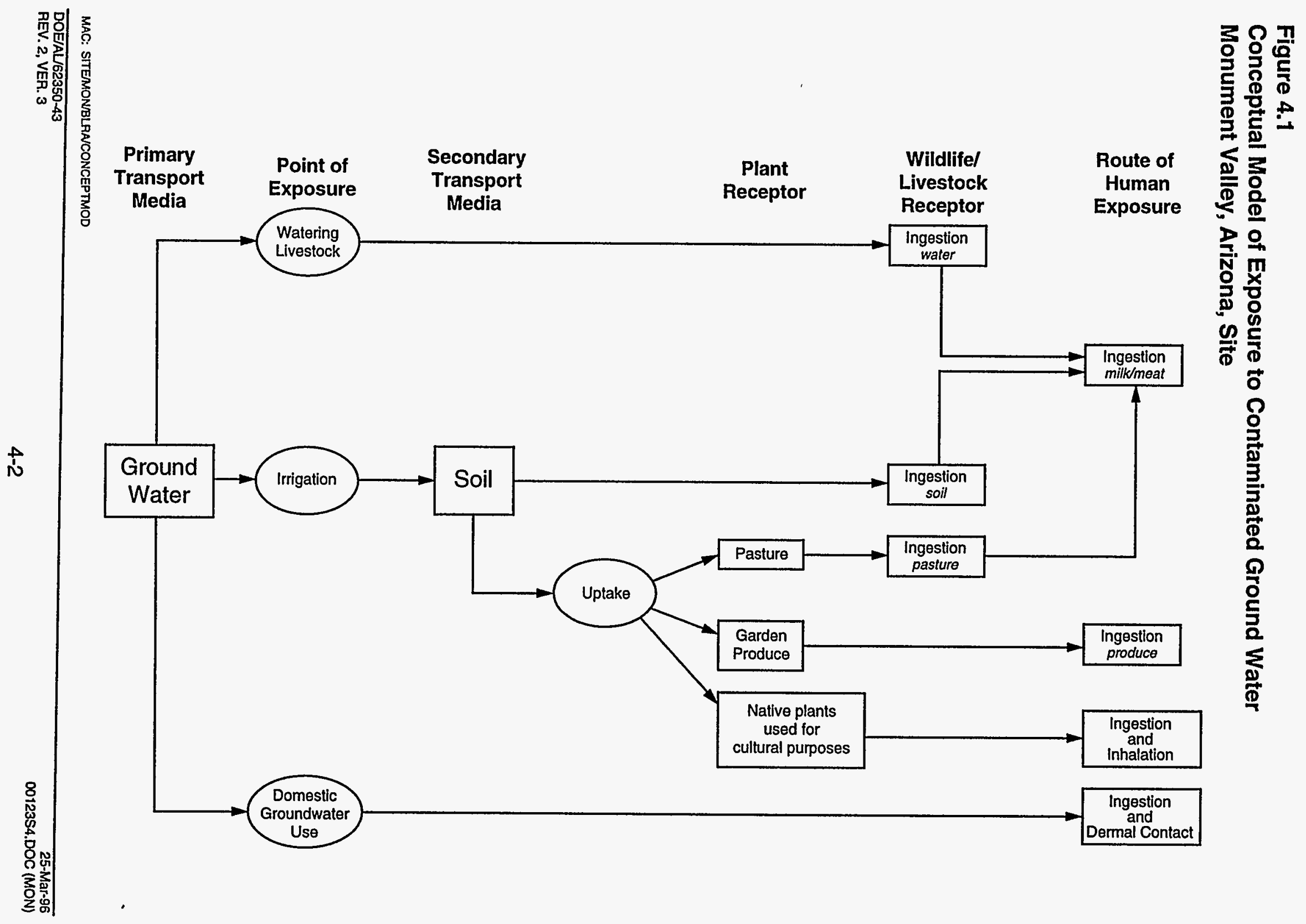


used for food preparation (e.g., reconstituted juice, soup, rice, and beans). To compare relative pathway significance, Table 4.1 shows a screening level assessment of drinking water intake. These calculations are based on estimates of the average concentrations of constituents in the most contaminated plume wells. Data from well 655 are used for all constituents except for manganese and nitrate. Data from well 606 are used for manganese and nitrate because concentrations of these two constituents are higher in well 606 than in well 655 . The average concentration of a constituent is conservatively estimated using the 95 percent upper confidence limit for the mean concentration of the constituent in ground water accessed by the plume well (DOE, 1996b).

\subsubsection{Dermal absorption}

Dermal absorption is the process by which chemicals coming into contact with the skin are absorbed into the blood vessels near the skin surface. While some compounds are absorbed easily, metals do not possess chemical properties conducive to skin absorption.

To evaluate this exposure route, a screening calculation was conducted to determine the significance of a dermal absorption pathway compared to a drinking water pathway for the constituents of potential concern. Chemical-specific absorption factors are not available for these constituents, therefore, they were assumed to be absorbed across the skin at the same rate as water. This assumption will probably result in an overestimate of any potential contribution from dermal absorption.

Table 4.1 presents the results of the screening. Based on these results, dermal absorption was eliminated from more detailed evaluation because it contributes less than 1 percent of the total intake from drinking water.

\subsubsection{Ingestion of ground water-irrigated produce}

Constituents in ground water could be taken up by plants either through roots in saturated soils or through irrigation water. Large-scale irrigation with ground water is not likely in this area. However, irrigation of garden plants with subsequent ingestion of contaminated produce is a potential future exposure pathway. Currently, not enough data exist in the literature to determine potential exposures from this pathway because the estimation of constituent uptakes by plants from water is uncertain. Therefore, this risk assessment does not present a screening calculation for exposure through plants. The DOE and the University of Arizona are studying constituent uptake by vegetables and grasses irrigated with contaminated ground water.

\subsubsection{Ingestion of meat or milk from ground water-fed livestock}

These pathways were eliminated from further consideration because the nitrate and sulfate concentrations are so high that livestock would not likely survive chronic ingestion of the water. If the livestock cannot consume the water, there is no 


\section{Table 4.1 Exposure dose calculations for ground water ingestion and dermal contact,} Monument Valley, Arizona, site

\begin{tabular}{|c|c|c|c|c|}
\hline \multirow{2}{*}{$\begin{array}{l}\text { Constituent of } \\
\text { potential } \\
\text { concern }\end{array}$} & \multirow[b]{2}{*}{$\begin{array}{c}\text { Cw } \\
(\mathrm{mg} / \mathrm{L})\end{array}$} & \multicolumn{2}{|c|}{$\begin{array}{c}\text { Ground water exposure doses } \\
\text { (mg/kg-day) }\end{array}$} & \multirow[b]{2}{*}{$\frac{\text { Dermal absorption }}{\text { water ingestion }}$} \\
\hline & & Ingestion & $\begin{array}{c}\text { Dermal } \\
\text { absorption }\end{array}$ & \\
\hline \multicolumn{5}{|c|}{ Noncarcinogenic effects } \\
\hline Manganese & 0.15 & 4E-03 & $8 E-06$ & 0.002 \\
\hline Nitrate & 1300 & $4 \mathrm{E}+01$ & 7E-02 & 0.002 \\
\hline Strontium & 3.1 & $8 \mathrm{E}-02$ & 2E-04 & 0.002 \\
\hline Sulfate & 2900 & $8 E+01$ & $2 \mathrm{E}-01$ & 0.002 \\
\hline Uranium & 0.03 & $8 \mathrm{E}-04$ & $2 E-06$ & 0.002 \\
\hline Vanadium & 0.02 & $5 \mathrm{E}-04$ & 1E-06 & 0.002 \\
\hline \multicolumn{5}{|c|}{ Carcinogenic effects } \\
\hline Uranium & $14^{b}$ & $3 E+05^{c}$ & $6 E+02^{c}$ & 0.002 \\
\hline
\end{tabular}

Equation Definitions for Exposure Dose Calculations

Ingestion of ground water

Chemicals: $\quad$ Chronic daily intake $\left(\mathrm{mg} / \mathrm{kg}\right.$-day) $=\frac{C w \times I R w \times E F \times E}{B W \times A T}$

Radionuclides: Lifetime intake ( $\mathrm{pCi}$ per lifetime) $=\mathrm{Cw} \times \mathrm{IRw} \times \mathrm{EF} \times \mathrm{ED}$

Dermal contact with ground water - carcinogens and noncarcinogens

Chemicals: Chronic daily intake $(\mathrm{mg} / \mathrm{kg}$-day $)=(\mathrm{Cw} \times \mathrm{SA} \times \mathrm{Pc} \times \mathrm{Cf}) \times E T \times E F \times E D$ $B W \times A T$

Radionuclides: Lifetime intake ( $p$ Ci per lifetime) $=\mathrm{Cw} \times \mathrm{SA} \times \mathrm{Pc} \times \mathrm{Cf} \times \mathrm{ET} \times \mathrm{EF} \times \mathrm{ED}$

Where:

$\mathrm{Cw}=$ Constituent concentration in ground water (upper 95 percent confidence level of the mean concentration in ground water accessed by the most contaminated well in the alluvial aquifer).

$\mathrm{IRw}=$ Ingestion rate for water (liters $[L]$ per day) (2 $L$ per day for an adult).

$E F=$ Exposure frequency ( 365 days per year).

ED = Exposure duration ( 30 years for an adult; 70 years for carcinogenic effects).

$\mathrm{BW}=$ Body weight (70 kilograms [kg] for an adult).

$A T=$ Averaging time ( 365 days $\times \mathrm{ED}$ for noncarcinogens; 365 days $\times 70$ years for carcinogens).

$S A=$ Skin surface area $\left(19,400\right.$ square centimeters $\left.\left[\mathrm{cm}^{2}\right]\right)$.

$\mathrm{Pc}=$ Dermal permeability constant $(0.001 \mathrm{~cm}$ per hour $)$.

$\mathrm{Cf}=$ Conversion factor $\left(0.001\right.$ liters per cubic centimeter $\left.\left[\mathrm{L} \mathrm{cm}^{3}\right]\right)$.

$E T=$ Exposure time (0.2 hour per day).

${ }^{a}$ Ratio of the dermal absorption exposure dose to the ground water ingestion exposure dose.

${ }_{\mathrm{pC}} \mathrm{i} / \mathrm{L}=$ Picocuries per liter.

pCi per lifetime.

$\mathrm{mg} / \mathrm{kg}$-day = milligrams per kilogram per day. 
potential for bioaccumulation or transfer of ingested constituents to meat tissue or milk. Section 7.0 presents further evaluation of the direct toxicity to livestock.

The results of the pathway screening analyses indicate drinking water ingestion is the dominant pathway of exposure for humans. Section 4.4 further evaluates this pathway using probabilistic methods.

\subsection{EXPOSURE CONCENTRATIONS}

The exposure concentration of a constituent in ground water is defined in this document as the average concentration an individual will contact over the period of exposure being considered. In this evaluation, the constituent concentrations are assumed to be in a steady state although actual constituent concentrations (and therefore exposures) are expected to decrease with time now that the tailings have been removed. Nonetheless, these estimates are reasonable for chronic exposure soon after surface remediation. (Chronic exposure for noncarcinogens is considered to be exposure for any period longer than 7 years.)

Exposure concentrations are evaluated as a probability of occurrence based on ground water data collected from monitor well 655 for strontium, sulfate, uranium, and vanadium. Since 1988, this well has consistently shown the highest concentrations of these constituents. Because manganese and nitrate levels in well 606 were greater than in well 655 , well 606 was used to estimate manganese and nitrate exposures.

The probability distribution selected for each constituent reflects the same mean, standard deviation, and shape as were observed in historical water quality data. For quantitative risk evaluation, the tails of the distribution were truncated (i.e., values below $0.0 \mathrm{mg} / \mathrm{L}$ and above the 99th percentile of the theoretical probability distribution were assigned zero probability). The probability associated with the disallowed portion was assigned proportionally to the allowable values so that the total probability under the truncated curve remained equal to 1.0. It was verified that this truncation is conservative because the 99th percentile is above the maximum observed concentration in each of the data sets used for this risk assessment. The software package @RISK (Palisade Corp, Newfield, New York) generated the probability curves for the constituents of potential concern. The results are shown in Figures 4.2 through 4.7 .

\subsection{ESTIMATION OF INTAKE}

The potential toxicity of noncarcinogenic constituents in drinking water depends primarily on long-term average daily consumption of the constituents per kilogram of body weight measured in milligrams of constituent ingested per kilogram of body weight per day (mg/kg-day). The following equation estimates chronic daily intake:

Concentration $\mathrm{x}$ ingestion rate $\mathrm{x}$ exposure frequency $\mathrm{x}$ exposure duration

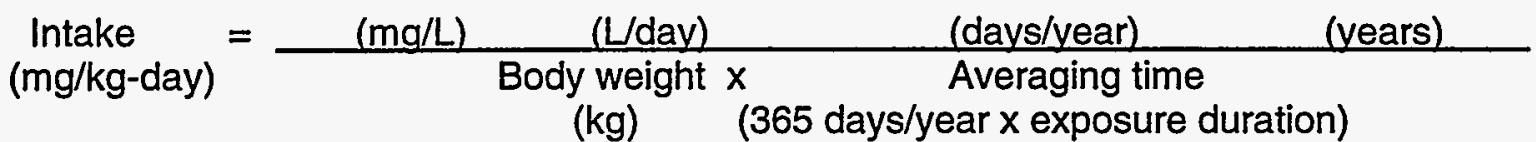


Figure 4.2

Simulated Distribution Of Nitrate Based On Data From Well 606 Monument Valley UMTRA Project Site

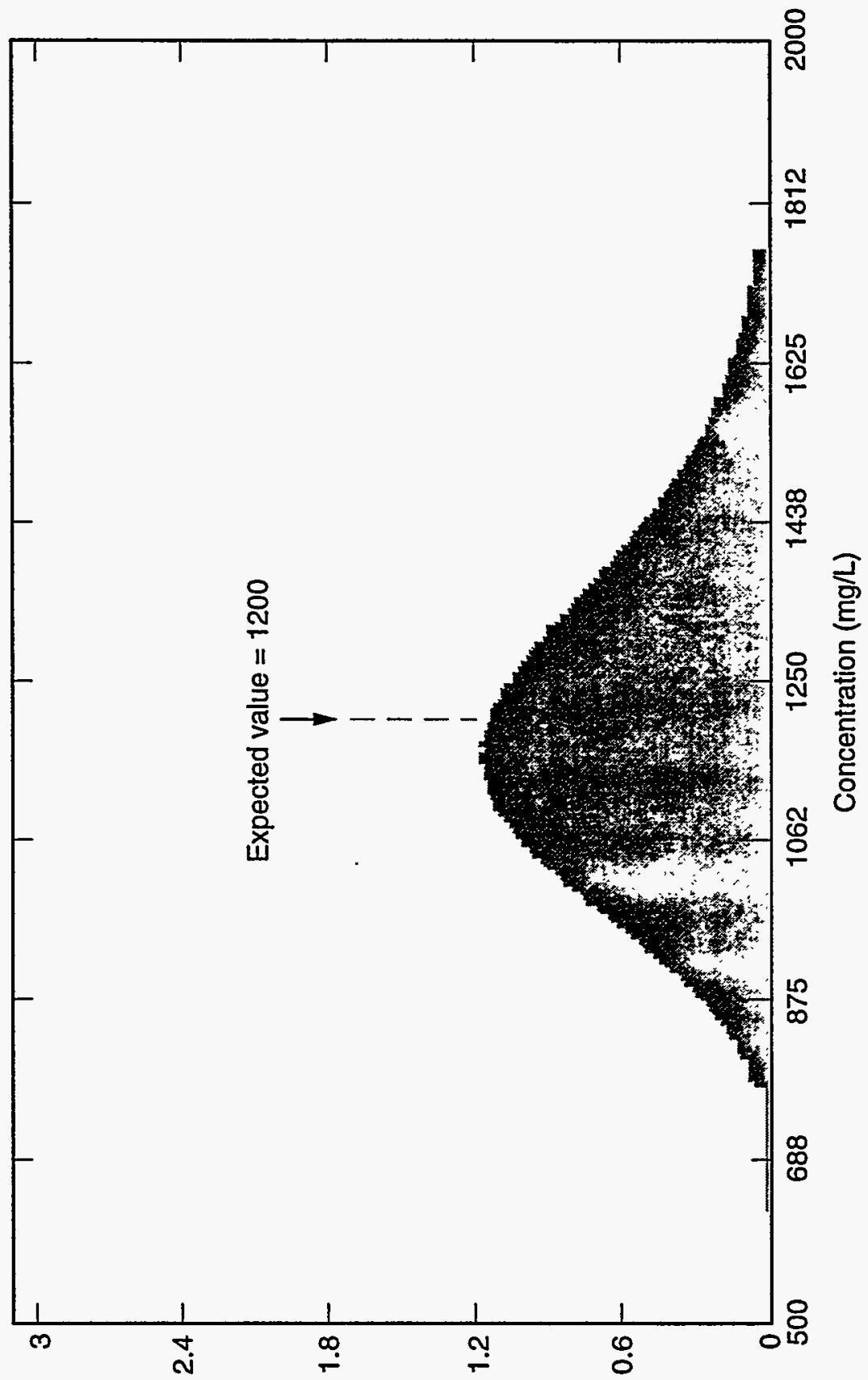

(\% se) Ki!!!qeqodd 


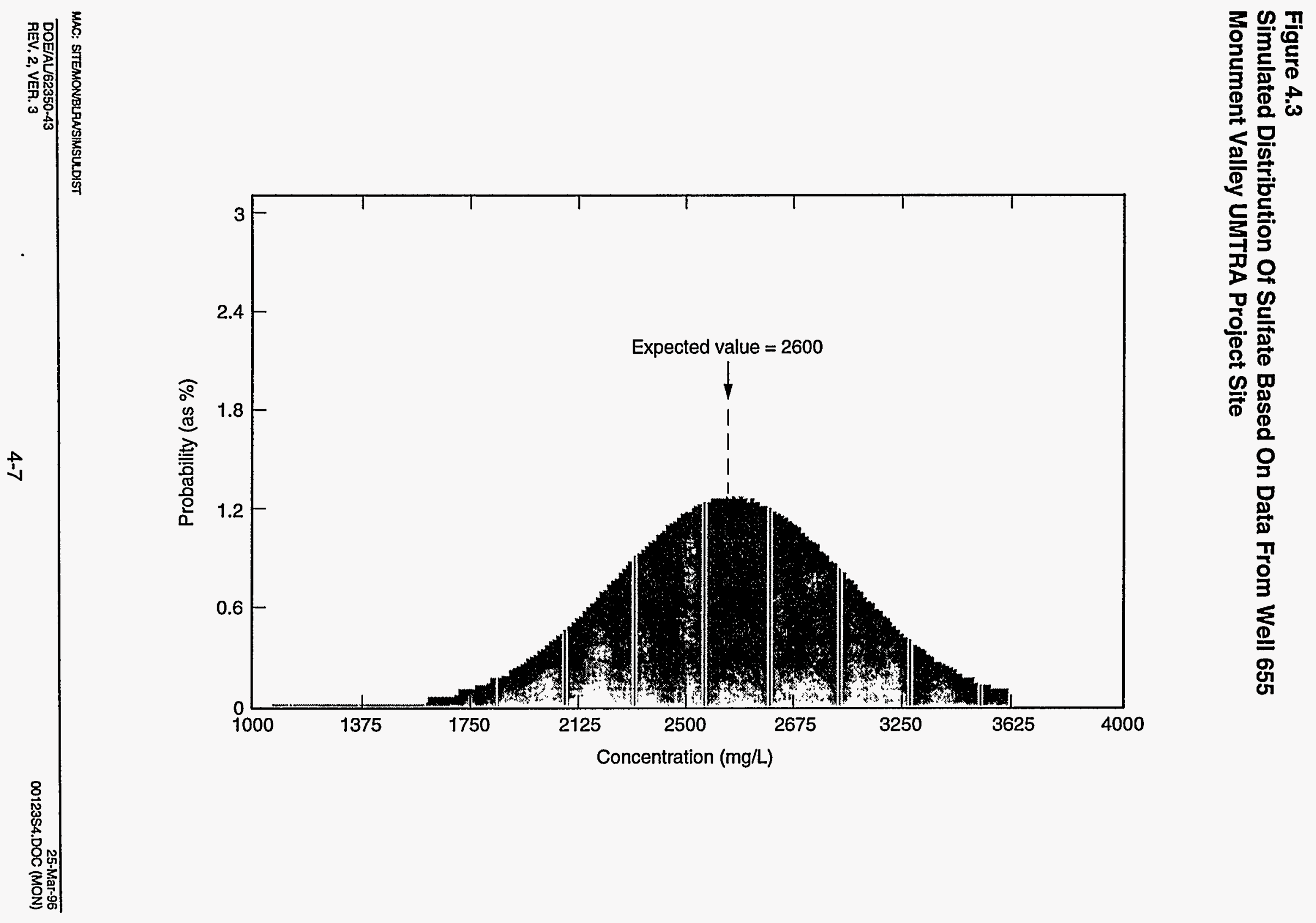


Figure 4.4

Simulated Distribution Of Strontium Based On Data From Well 655 Monument Valley UMTRA Project Site

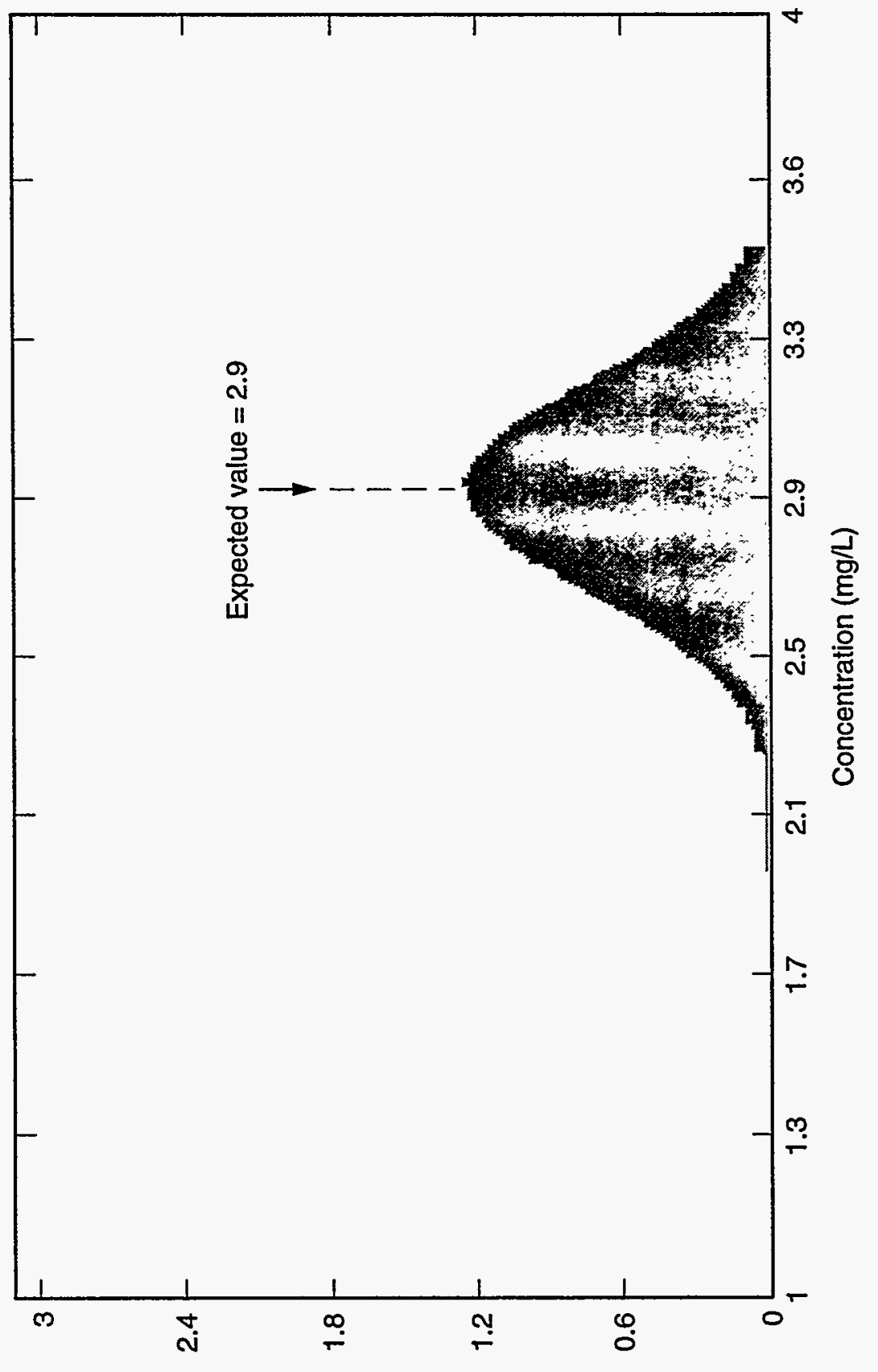

(\% se) K!!!!qeqodd 
Figure 4.5

Simulated Distribution Of Uranium Based On Data From Well 655 Monument Valley UMTRA Project Site

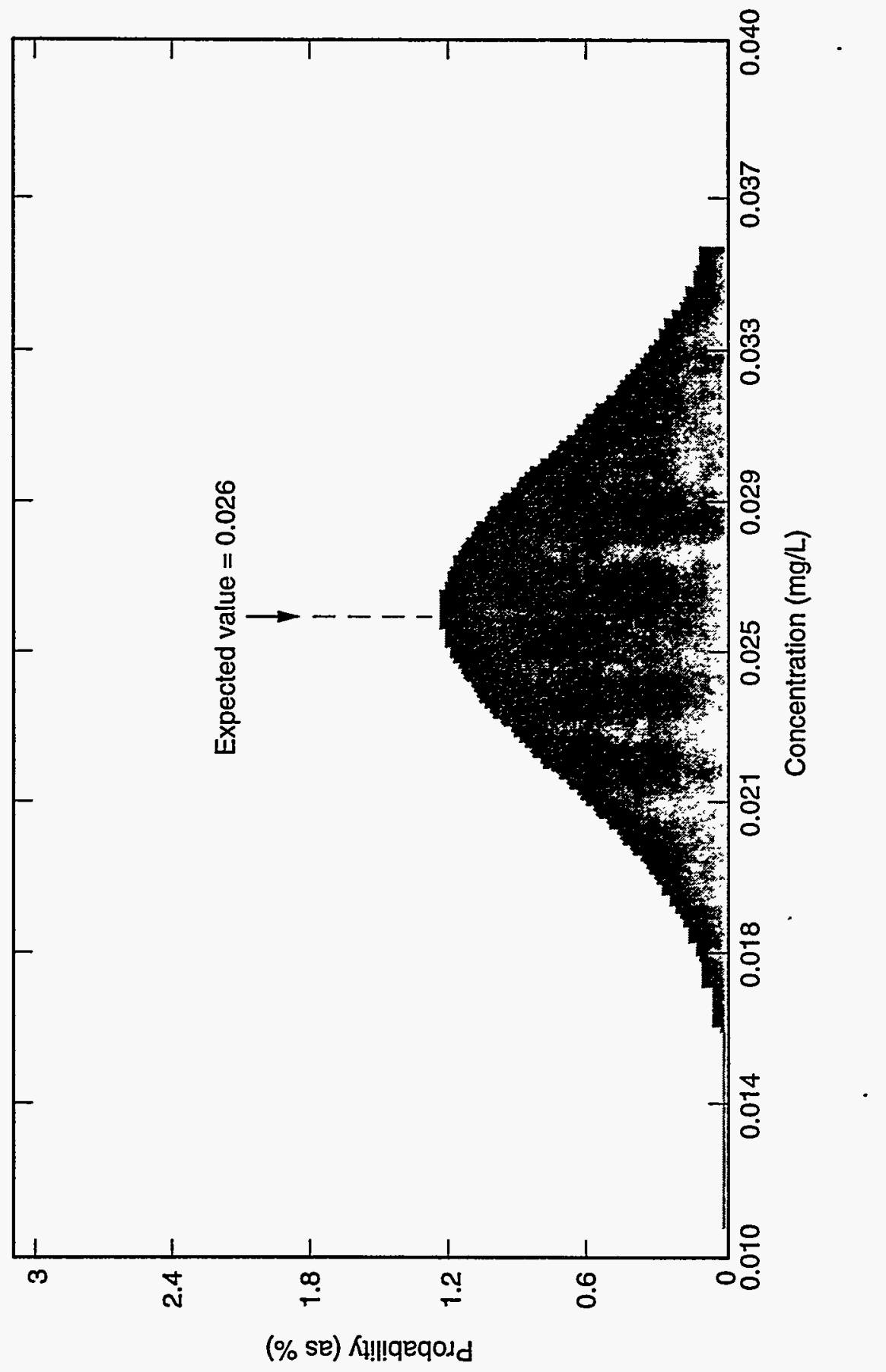

MAC: SIEMONBLRASIMURANDIST 
Figure 4.6

Simulated Distribution Of Vanadium Based On Data From Well 655

Monument Valley UMTRA Project Site

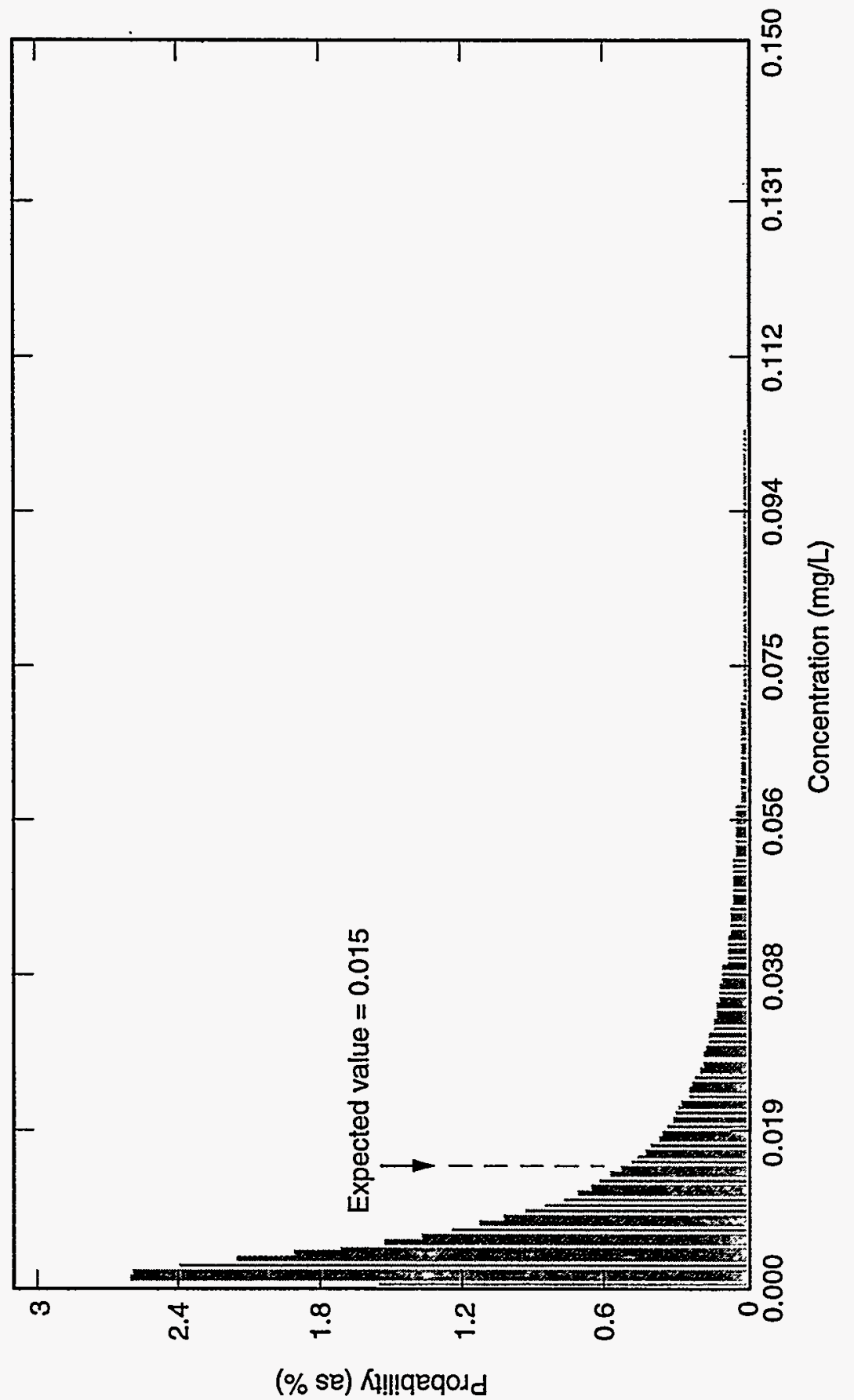


Figure 4.7

Simulated Distribution Of Manganese Based On Data From Well 606 Monument Valley UMTRA Project Site

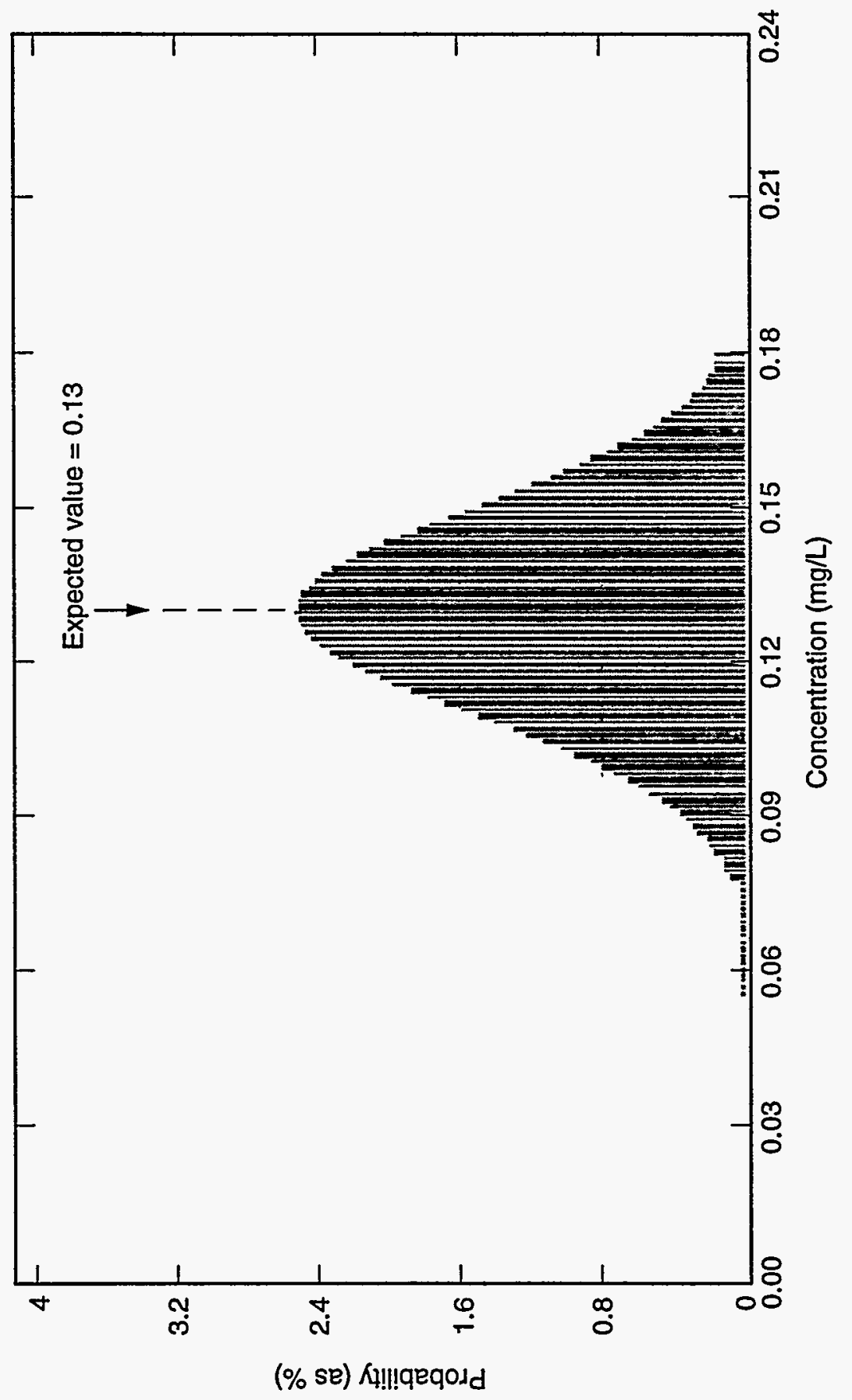


Potential carcinogenicity of radionuclides is thought to increase with total intake over time, instead of with average daily intake as for noncarcinogens. Also, body weight is relatively insignificant in determining risk from exposure. Intake of a radioactive carcinogenic substance is therefore quantified as total exposure (measured in picocuries [pCi]) to radioactivity throughout the residency period of an individual:

Intake $=$ Concentration $\mathrm{x}$ ingestion rate $\mathrm{x}$ exposure frequency $\mathrm{x}$ exposure duration

$(\mathrm{pCi} /$ lifetime $) \quad(\mathrm{pCi} / \mathrm{L}) \quad(\mathrm{L} / \mathrm{day}) \quad$ (days/year) (years)

Future residents within the population are expected to vary in their water consumption, stable body weight, and length of time in the potential contamination zone. Consequently, health risks associated with ground water consumption will vary among members of this population. To describe the range of potential risks to the future population, naturally occurring variability in daily water intake and body weight were incorporated in this assessment through probability distributions that were developed from United States public health and census documents (DOE, 1996b). These distributions and other constants used in exposure calculations are discussed further below.

\section{Average dailv intake (L/dav)}

Log normal probability distributions were used to describe the variation in average daily tap water intake among members of the population (Roseberry and Burmaster, 1992). These distributions were developed from data collected during the 1977-78 National Food Consumption Survey conducted by the U.S. Department of Agriculture (DOE, 1996b). During the survey, total tap water consumption during a 3-day period was recorded for 26,081 survey participants nationwide (Figure 4.8).

\section{Exposure frequency (days)}

Individuals are typically exposed fewer than 365 days per year because of time away from home (e.g., vacations). However, exposure frequency is expected to be higher among potential future residents of the Monument Valley site than among the United States population as a whole. In the absence of reliable site-specific information on this variable, exposure of 365 days per year was assumed throughout this document.

\section{Body weight $(\mathrm{kg})$}

The National Health and Nutrition Survey collected extensive national data on weights of males and females, by age, between 1976 and 1980. These data were used to develop lognormal probability distributions for body weight by age, separately by gender (DOE, 1996b). The distributions for males and females were then combined using census data on the national ratio of males to females within each age group (Figure 4.9). 
Figure 4.8

Probability Distributions For Tap Water Ingestion Rates By Age Group Monument Valley UMTRA Project Site
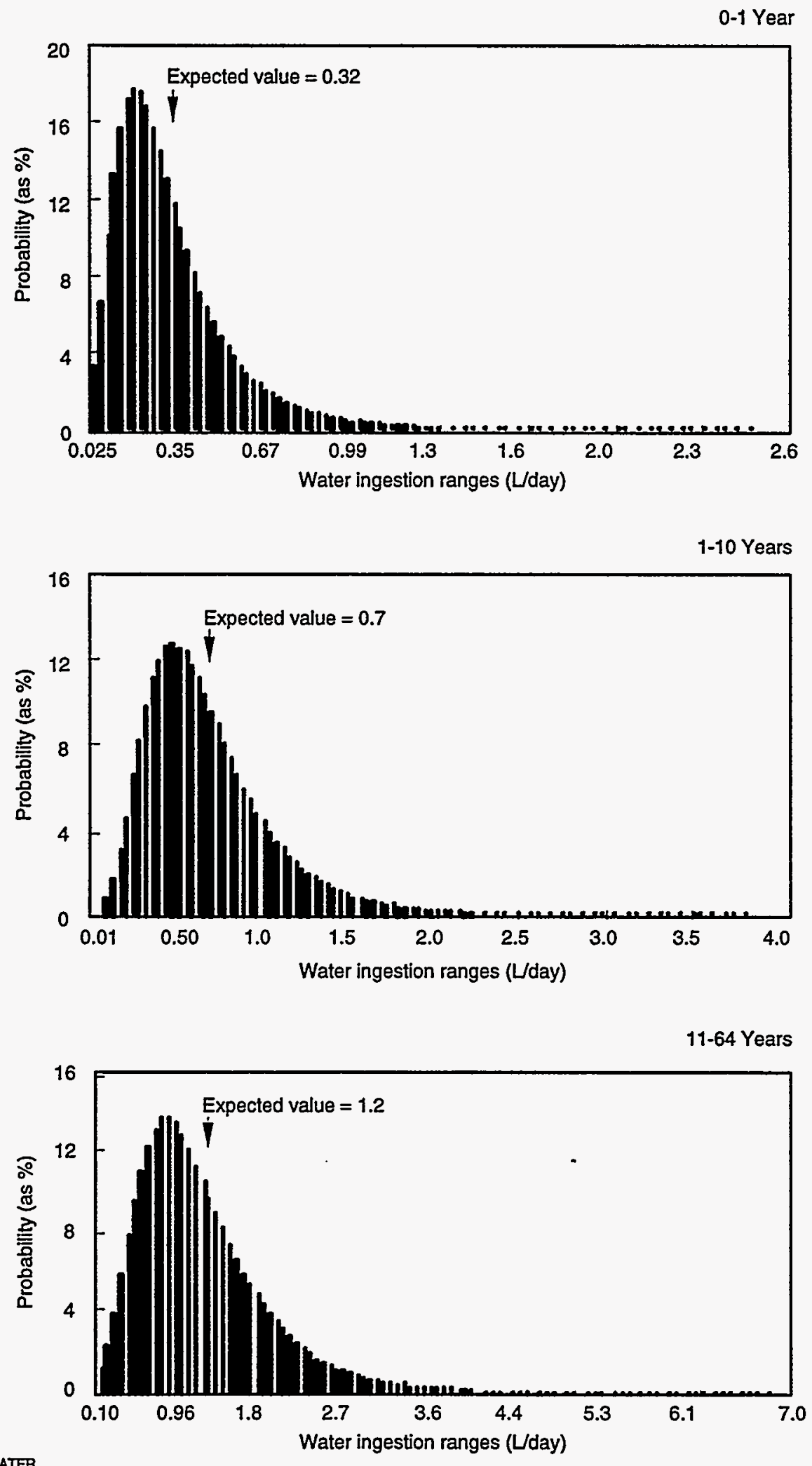

Water ingestion ranges (L/day) 
Figure 4.9

Body Weight Probability Distributions By Age Group Monument Valley UMTRA Project Site

0-1 Year

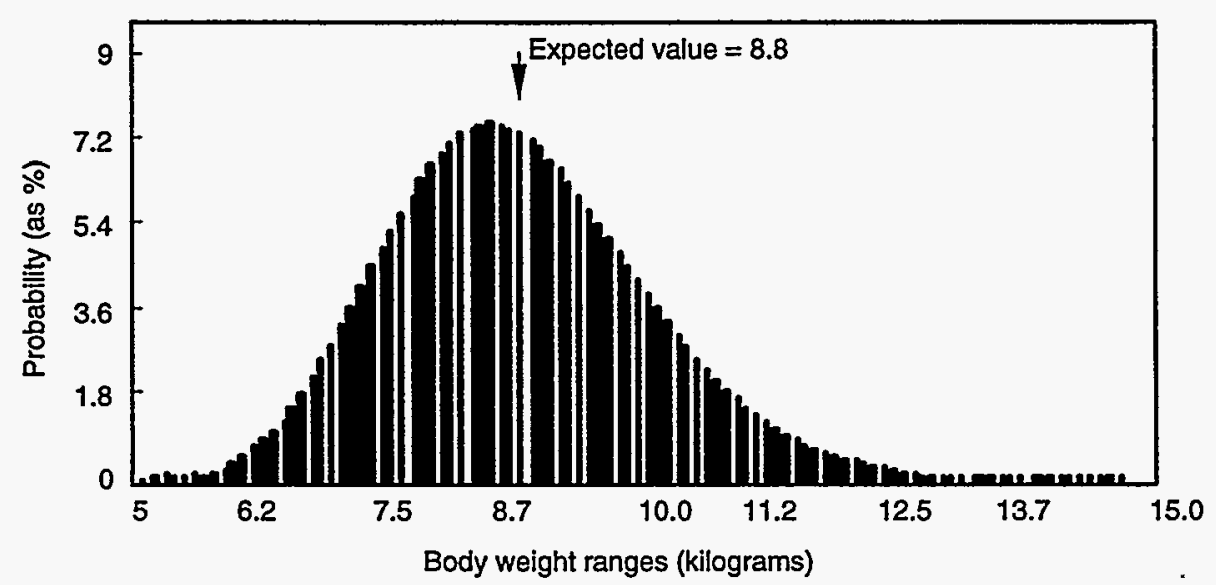

1-10 Years

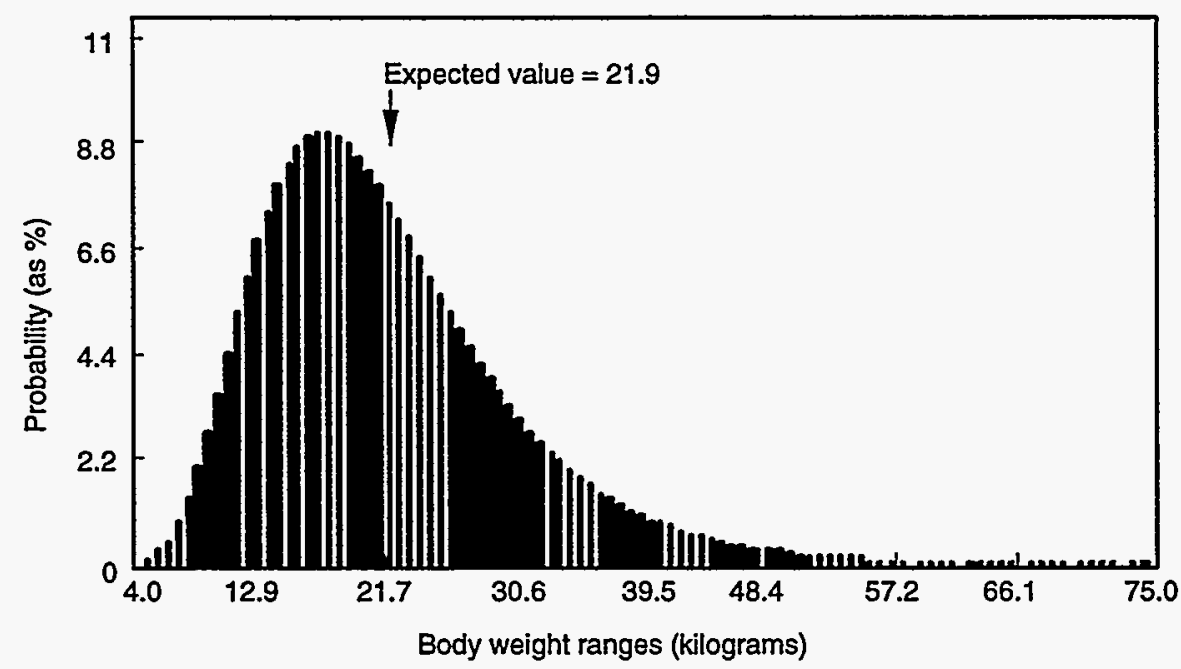

$11-64$ Years

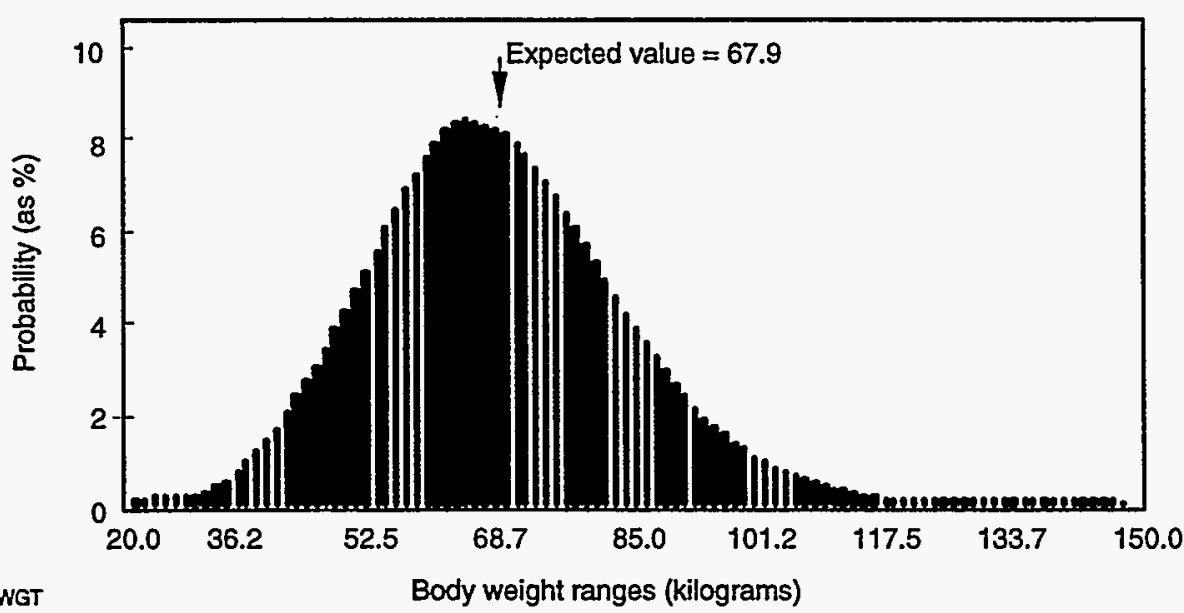

MAC: STEEMONBLRABODYWGT 


\section{Exposure duration (years)}

For noncarcinogenic effects, the exposure duration term in the numerator and denominator of the drinking water intake equations cancel out, assuming all exposures are chronic; i.e., greater than 7 years. Therefore, deviations from the standard residence time assumptions do not affect the results. For carcinogens, however (because risk is cumulative throughout a lifetime), deviations from the hypothesized distribution could significantly affect the risk estimate. Given the grazing permit system used by the Navajo Nation for land allocation, residents frequently can be in the same region for an entire lifetime. No available data adequately model this longer residence time. Therefore, a fixed lifetime exposure duration of 70 years was used to model lifetime cancer risks.

\section{Exposed populations}

The potentially exposed populations considered in the risk assessment include the following age groups: infants (birth to 1 year old), children ( 1 to 10 years old), and adults ( 11 to 64 years old). These age groups were selected for the following reasons:

- Survey data for population variables such as age, weight, and daily water intake are available for these age groups.

- Toxicological variables are similar within these age groups, including responsiveness of sensitive subgroups (infants and children) to the constituents of potential concern, toxicant intake to body weight ratios, and toxicokinetics.

Of these three age groups, exposure per kilogram of body weight is generally greatest in the 1- to 10-year age group (Figure 4.10 presents an example). Therefore, this group is used in the risk evaluation unless one of the other age groups demonstrates increased sensitivity to a particular constituent. Of the constituents at the Monument Valley site, a more sensitive age group is known only for nitrate and sulfate. Consequently, the nitrate and sulfate exposure risk determinations are based on infant exposure. Figures 4.11 through 4.15 present simulated intake distributions for appropriate age groups for site constituents.

\subsection{EXPOSURE ASSESSMENT UNCERTAINTIES}

A number of potential sources of error may arise in all phases of the exposure assessment, including the following more significant sources of uncertainty:

- Uncertainties resulting from the lack of thorough environmental sampling of ground water, which could lead to an underestimation or overestimation in the exposure analysis.

- Uncertainties arising from the assumption that the ground water contaminant source term at the site has reached a steady state and that constituent concentrations at the exposure point will remain constant for chronic periods of exposure (generally greater than 7 years). Because the source of 
Figure 4.10

Comparison of Distributions Of Potential Sulfate Exposures As A Result

Of Drinking Contaminated Ground Water For The Three Age Groups Examined Monument Valley UMTRA Project Site
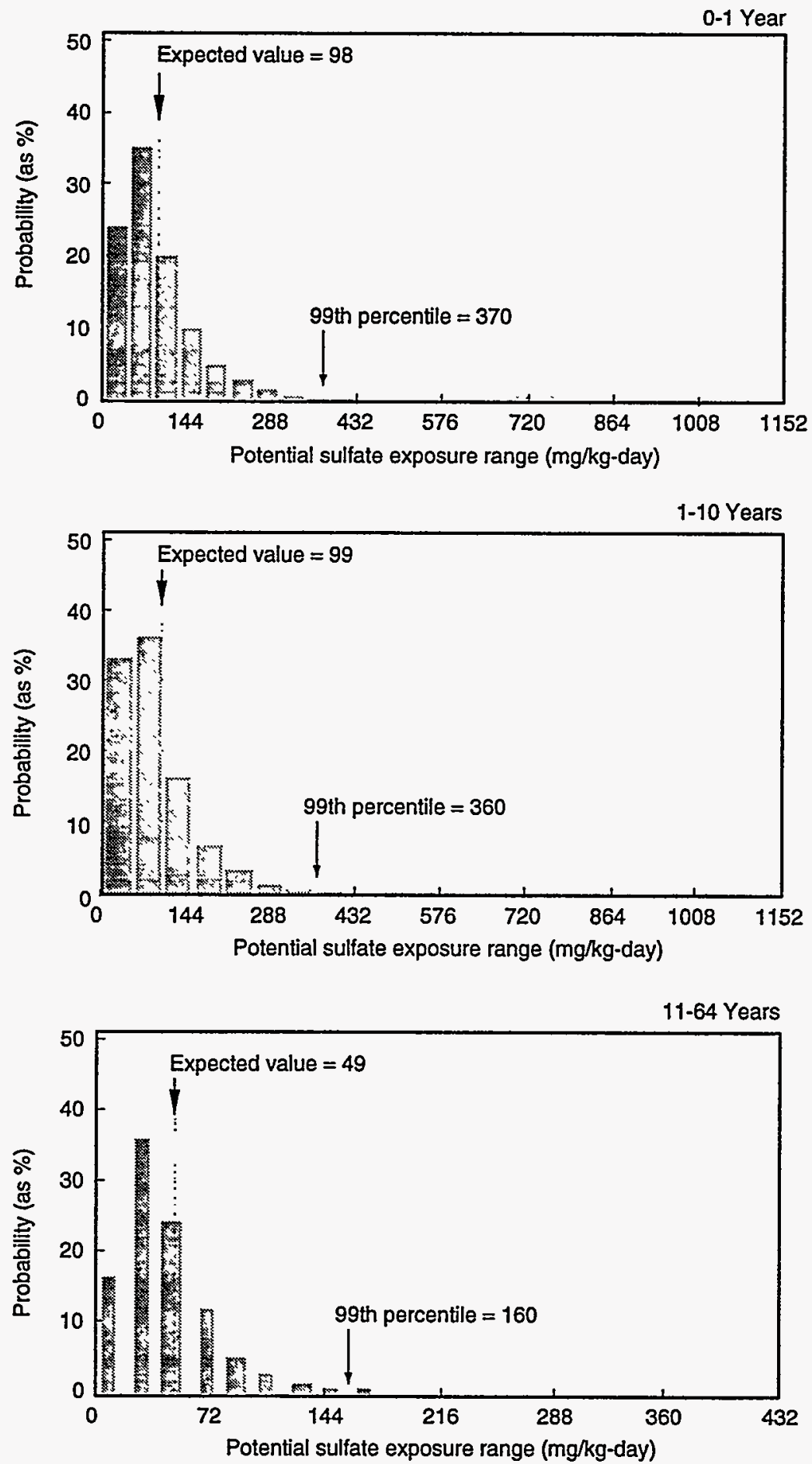

MAC: STEMONBLRNAGECOMP

Note: Highest potential exposure occurs in children age $1-10$ (average potential exposure of $99 \mathrm{mg}$ sulfate $/ \mathrm{kg}$ body weight. 
Figure 4.11

Distribution Of Potential Nitrate Exposures For Infants Consuming Contaminated Ground Water Monument Valley UMTRA Project Site
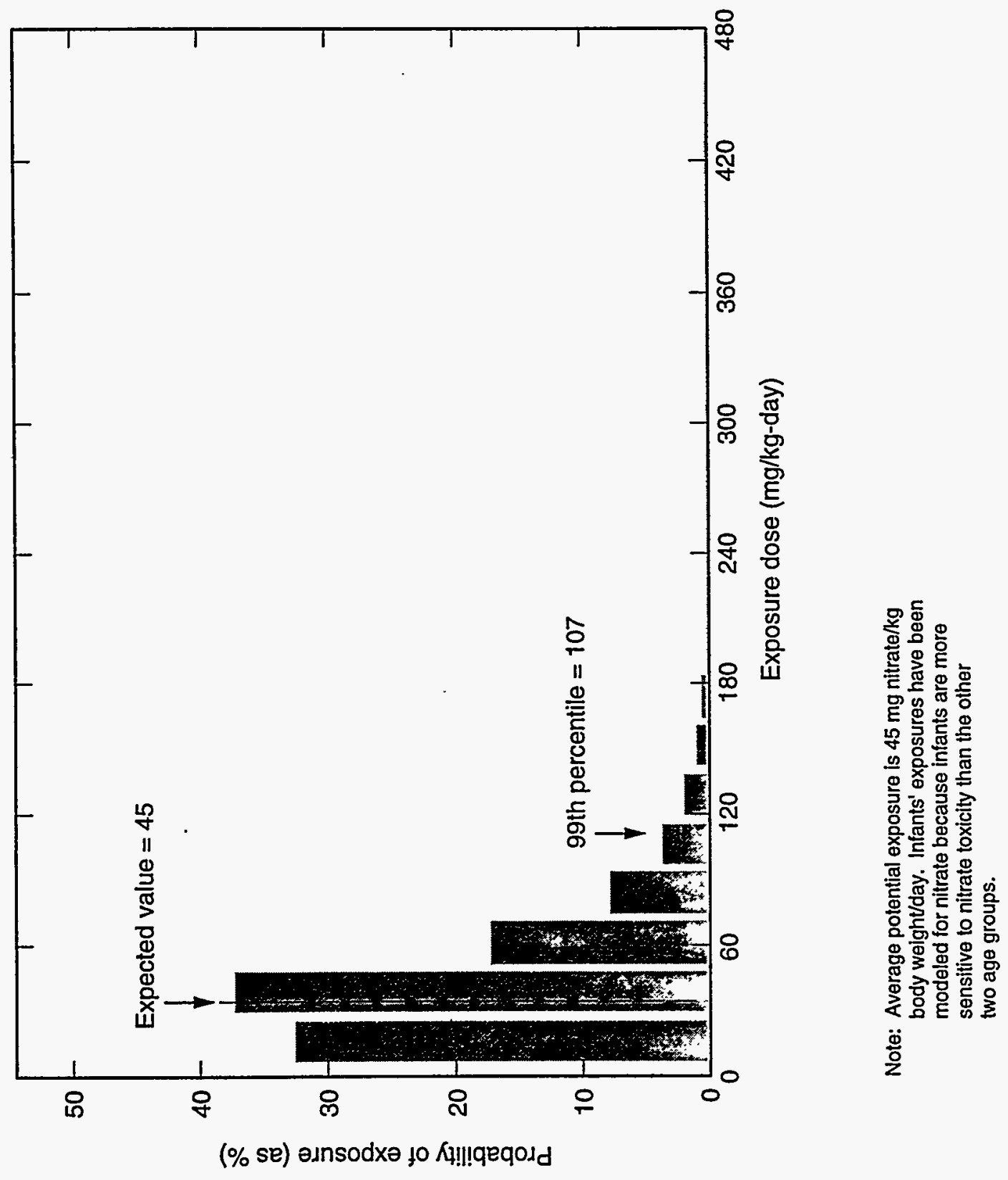

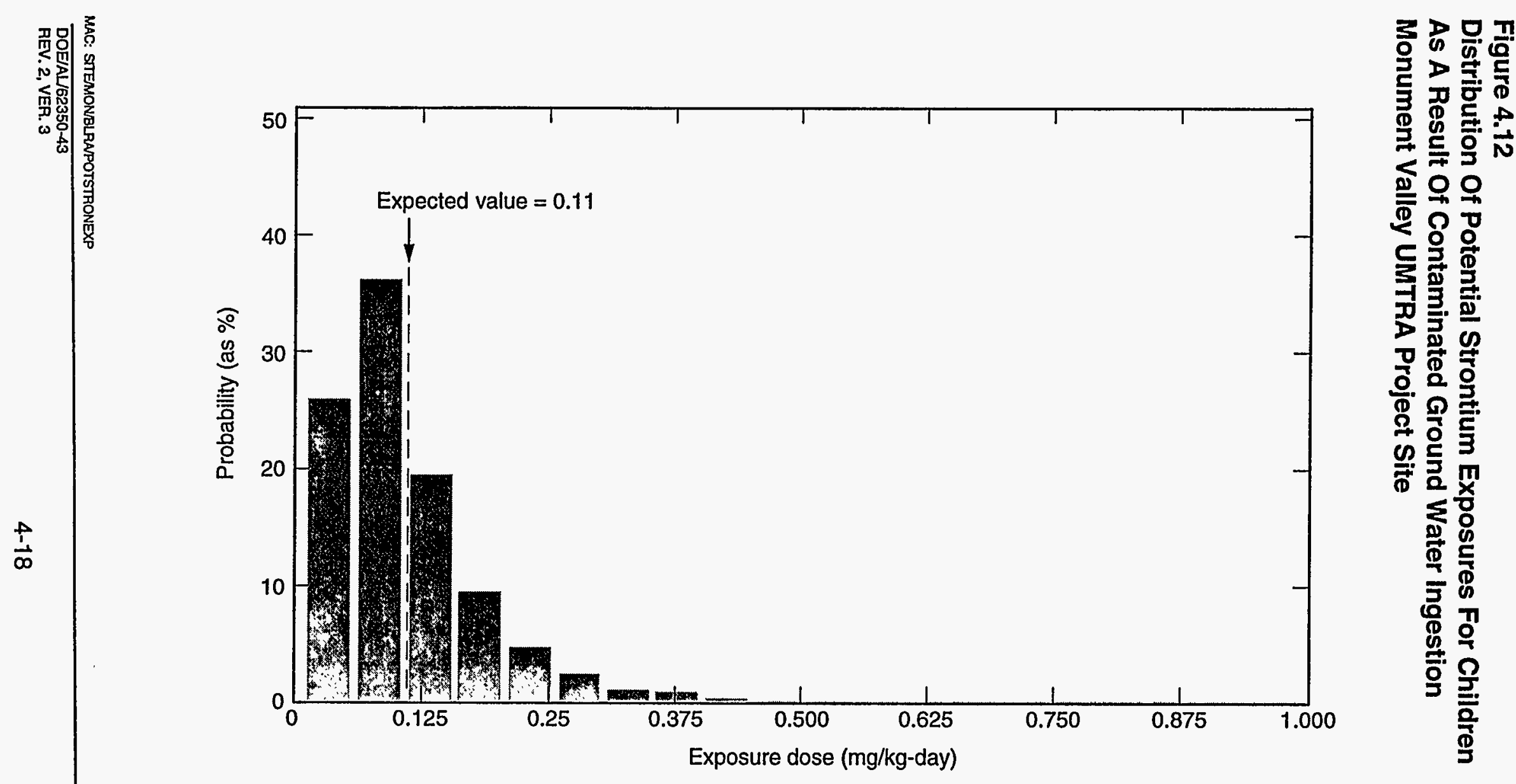

Note: Average potential exposure is $0.11 \mathrm{mg}$ strontium/ $\mathrm{kg}$ body weight/day. Exposures for children have been modeled because their intake/kg body weight is greatest and no sensitive population has been identified. 
Figure 4.13

Distribution Of Potential Uranium Exposures For Children

As A Result Of Contaminated Ground Water Ingestion

Monument Valley UMTRA Project Site

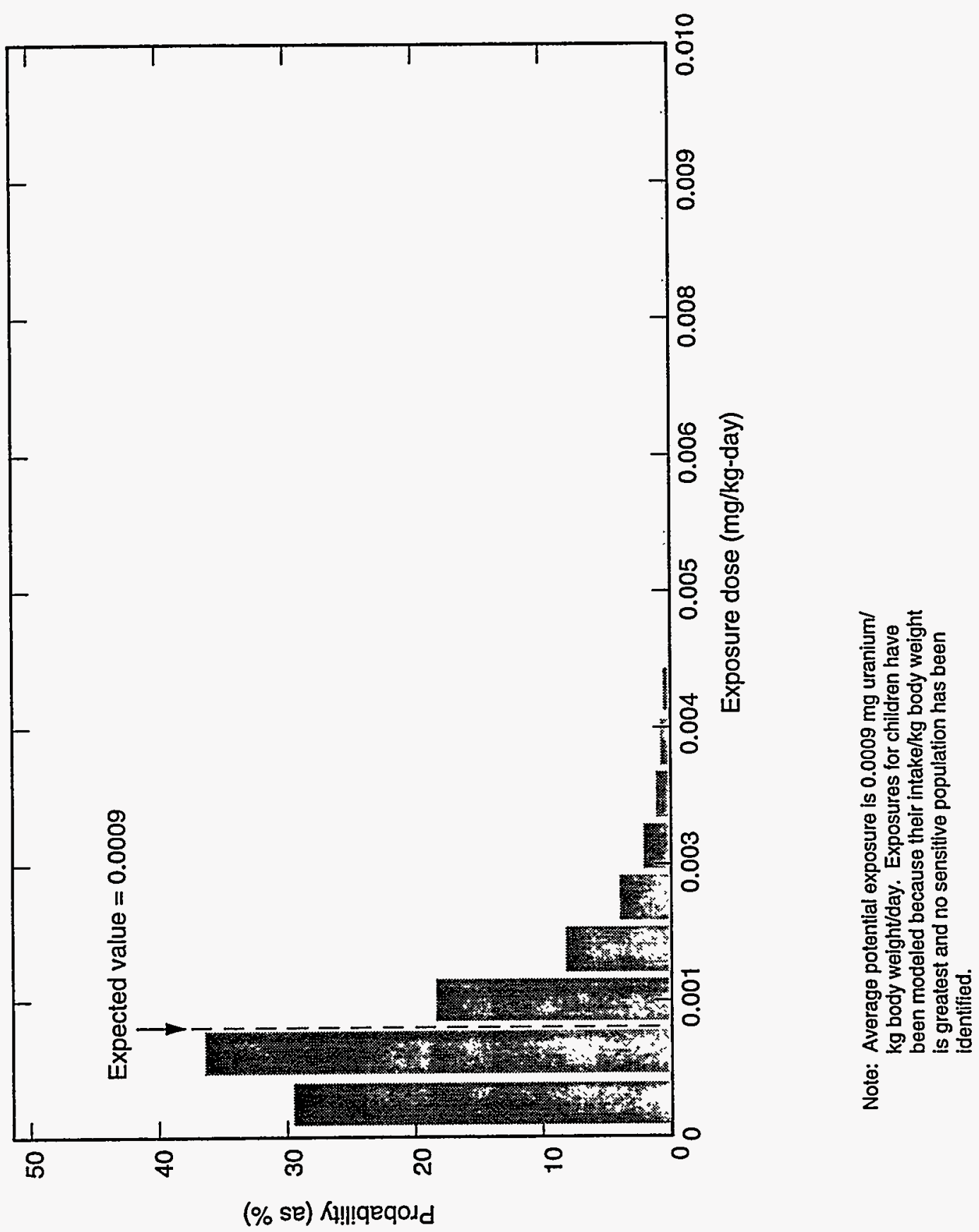


Figure 4.14

Distribution Of Potential Vanadium Exposures For Children As A Result Of Contaminated Ground Water Ingestion Monument Valley UMTRA Project Site

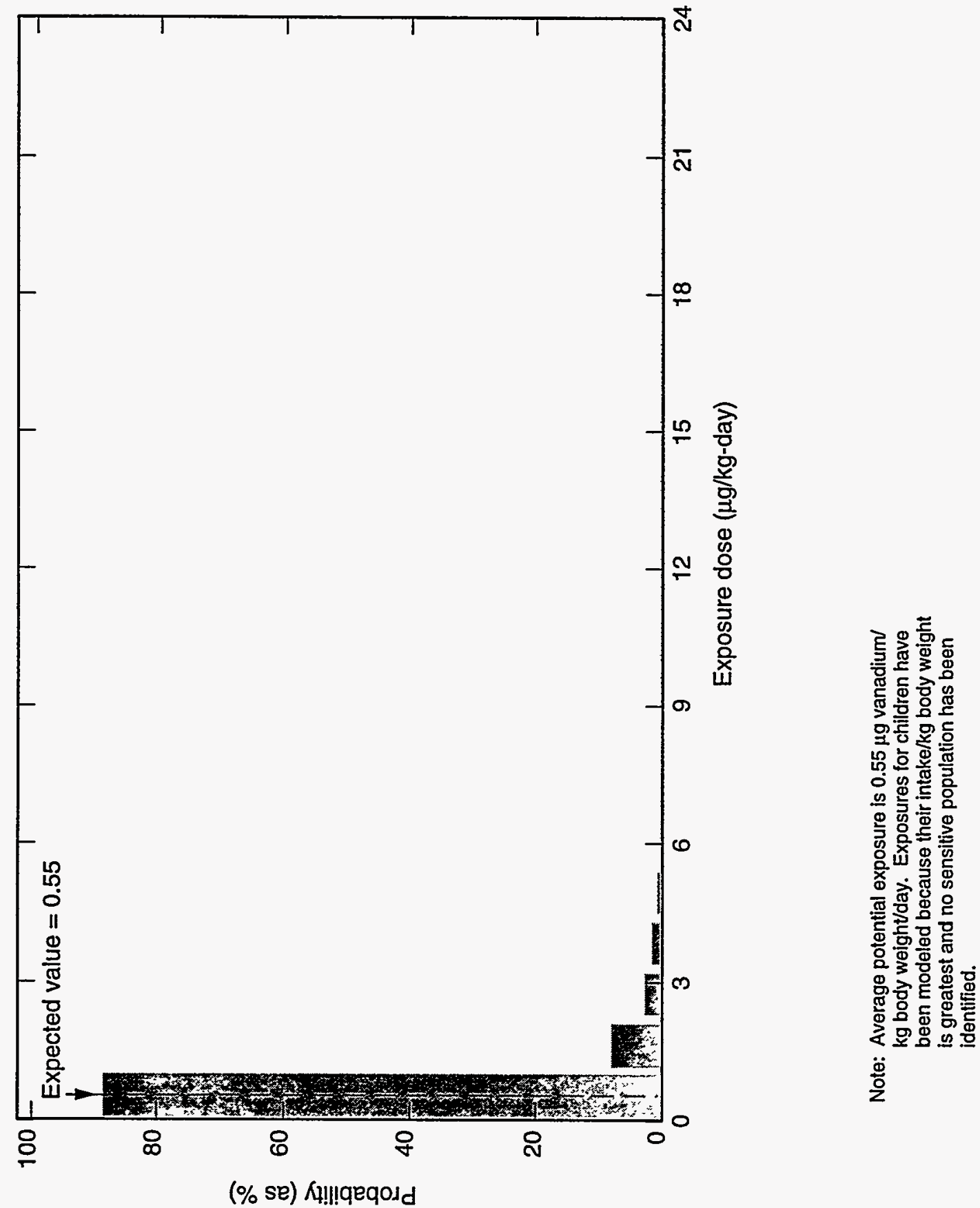


Figure 4.15

Distribution Of Potential Manganese Exposures For Children

As A Result Of Contaminated Ground Water Ingestion

Monument Valley UMTRA Project Site
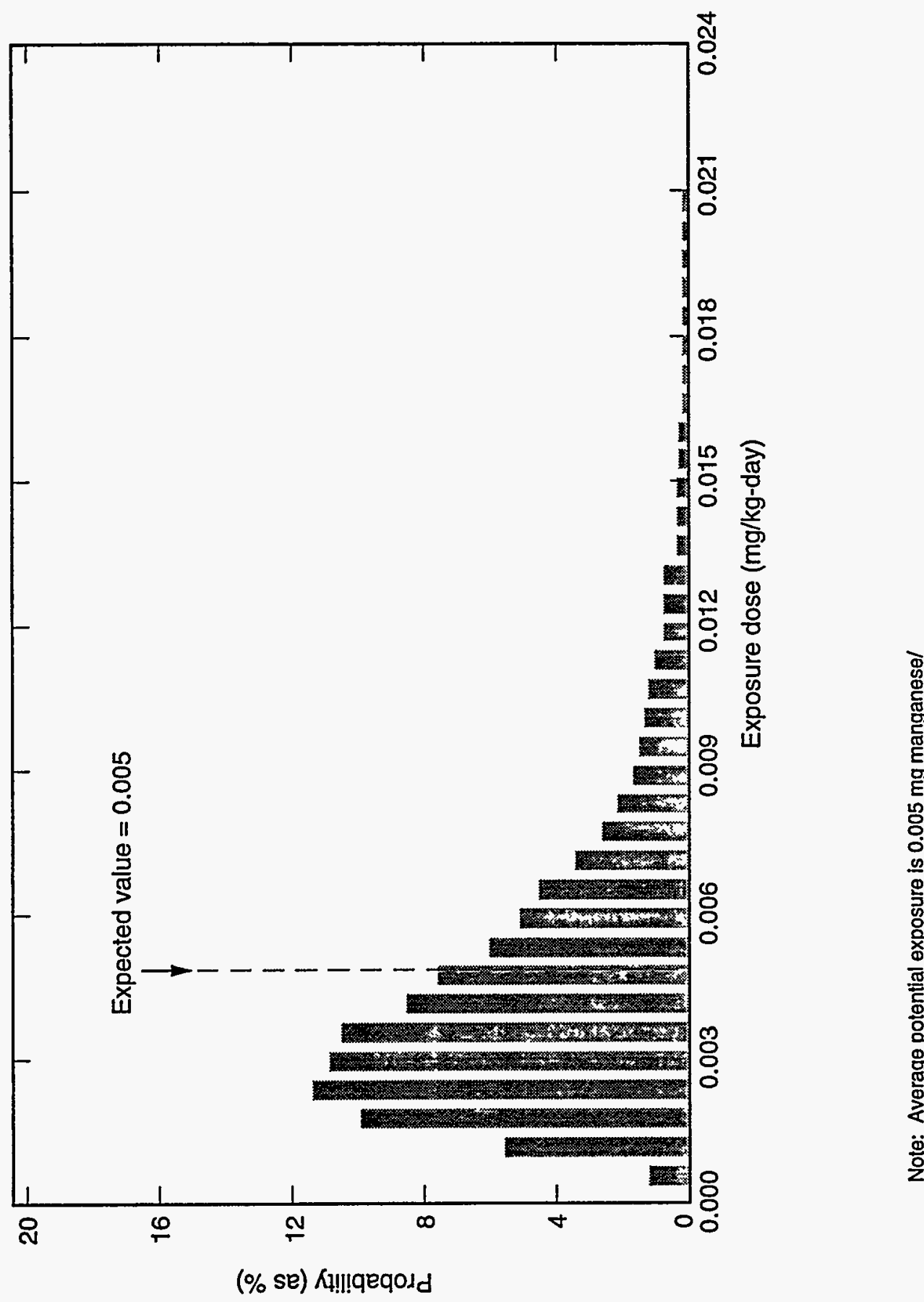
contamination at the Monument Valley site has been removed, the assumption of a constant source will likely lead to an overestimation of risk.

- Uncertainties associated with the relationship of an applied, absorbed, or effective toxic dose. (An applied dose was used here.)

- Uncertainties associated with differing sensitivities of subpopulations. For example the Navajo population has a high rate of diabetes, which could affect how constituents are metabolized.

Despite these uncertainties, the use of probability distributions that incorporate all definable sources of variability provides a representative picture of the potential range of exposures. 


\subsection{TOXICITY ASSESSMENT}

Six constituents that could have the potential to adversely affect human health have been identified in ground water at the Monument Valley site: nitrate, strontium, sulfate, manganese, uranium, and vanadium. This section summarizes the toxicological effects of the chemical constituents and the carcinogenic potential of uranium. The following source materials were used in developing these toxicological profiles: EPA's Integrated Risk Information System (IRIS); the Agency for Toxic Substances Disease Registry Toxicological Profiles published by the Department of Health and Human Services (DHHS); and the Handbook on the Toxicology of Metals (Friberg et al., 1986). When these review documents were not available, peerreviewed scientific literature was used as cited. By basing toxicity information on the standardized review documents cited above, the evaluation of risks at UMTRA Project sites should be consistent with evaluations at sites regulated under different legislation.

The toxicity profiles presented here will focus on drinking water source material in humans whenever available and will include animal information only when human data are not obtainable. Widely spaced dotted lines will represent animal information on the toxicity range graphs. When uncertainty exists about the beginning or end of a range of exposures that produces specific toxic effects, closely spaced dots will be used at the applicable end of the line denoting range.

\section{$5.1 \quad$ TOXICITY VALUES}

The EPA Office of Research and Development has calculated acceptable intake values, or reference doses (RfD), for long-term (chronic) exposure to noncarcinogens. These values are estimates of route-specific exposure levels that would not be expected to cause adverse effects when exposure occurs for a significant portion of the lifetime. The RfDs include safety factors to account for uncertainties associated with limitations of the toxicological data base, including extrapolating animal studies to humans and accounting for response variability from sensitive individuals. These values are updated quarterly and published in the Health Effects Assessment Summary Tables (HEAST) (EPA, 1992a). Following more extensive review, they also are provided through the EPA's IRIS data base. Table 5.1 summarizes the most recent oral RfDs for the noncarcinogenic effects of constituents of potential concern.

The EPA currently classifies all radionuclides as Group A, or known human carcinogens, based on their property of emitting ionizing radiation and on the evidence provided by epidemiological studies of radiation-induced cancer in humans. At sufficiently high doses, ionizing radiation acts as a complete carcinogen (both initiator and promoter), capable of increasing the probability of cancer development. However, the actual risk is difficult to estimate, particularly for the low doses and dose rates encountered in the environment. Most reliable data were obtained under conditions of high doses delivered 
Table 5.1 Toxicity values: potential noncarcinogenic effects

\begin{tabular}{|c|c|c|c|c|c|}
\hline Constituent & $\begin{array}{c}\text { Chronic oral RfD } \\
\text { (mg/kg-day) }\end{array}$ & Confidence level $^{\mathrm{a}}$ & Critical effect/organ & $\begin{array}{c}\text { RfD basis/RfD } \\
\text { source }\end{array}$ & Uncertainty factor $^{b}$ \\
\hline Nitrate & $7.0^{c}$ & High & $\begin{array}{l}\text { Methemoglobinemia, } \\
\text { hematologic }\end{array}$ & Water/IRIS & 1 \\
\hline Strontium & 0.6 & Medium & Bone & Water/IRIS & 300 \\
\hline Sulfate & NA & NA & Diarrhea & NA & NA \\
\hline $\begin{array}{l}\text { Uranium } \\
\text { (soluble salts) }\end{array}$ & 0.003 & Medium & $\begin{array}{l}\text { Kidney, decreased body } \\
\text { weight }\end{array}$ & Water/IRIS & 1000 \\
\hline Vanadium & 0.007 & Low & Hair & Water/HEAST & 100 \\
\hline Manganese & 0.005 & Medium to low & Central nervous system & Water/IRIS & 10 \\
\hline \multicolumn{6}{|c|}{ 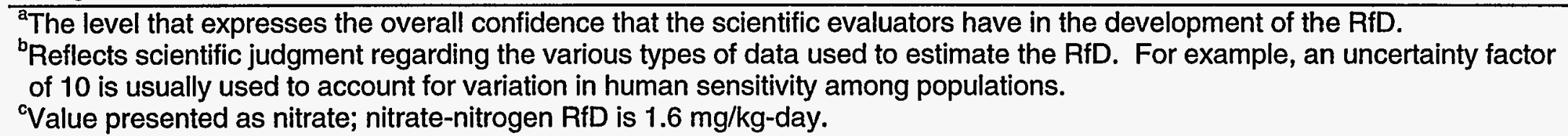 } \\
\hline
\end{tabular}


acutely. It is not clear whether cancer risks at lower doses are dose-proportional (i.e., the linear dose-response hypothesis) or whether the risk is greatly reduced at low doses and rates (the threshold hypothesis). A conservative assumption is that no threshold dose exists below which there is no additional cancer risk. Risk factors are published in HEAST and IRIS for correlating intake of carcinogens over a lifetime with the increased excess cancer risk from that exposure. Table 5.2 gives the most recent cancer slope factors for uranium-234 and -238 .

Table 5.2 Toxicity values: carcinogenic effects

\begin{tabular}{ccccc}
\hline Constituent & $\begin{array}{c}\text { Oral SF } \\
\left(\mathrm{pCi}^{-1}\right)\end{array}$ & $\begin{array}{c}\text { Weight of evidence } \\
\text { classification }\end{array}$ & $\begin{array}{c}\text { Type of cancer } \\
\text { SF basis/SF source }\end{array}$ \\
\hline Uranium-238 & $4.27 \mathrm{E}-11^{\mathrm{a}}$ & $\mathrm{A}$ & $\mathrm{b}$ & Water/HEAST \\
Uranium-234 & $4.44 \mathrm{E}-11^{\mathrm{a}}$ & $\mathrm{A}$ & $\mathrm{b}$ & Water/HEAST \\
\hline
\end{tabular}

${ }^{\mathrm{a}}$ The average SF for uranium-238 and -234 is $4.35 \mathrm{E}-11$.

${ }^{\mathrm{b}}$ No human or animal studies have shown a definite association between exposure to uranium and development of cancer.

$\mathrm{pCi}$ - picocuries.

SF - Slope factor; values from 1995 supplement to EPA, $1992 a$.

A - EPA classification for known human carcinogens.

\subsection{CONTAMINANT TOXICITY SUMMARIES}

The basic toxicokinetics and toxicity of each of the constituents of potential concern at the Monument Valley site are summarized below. Wherever possible, data from human studies will be addressed. Only in cases where human data are unavailable will animal studies be reported. Although these constituents of potential concern have a wide range of toxic effects depending on exposure level, the following discussions will focus on toxic effects observed in the exposure range most relevant to contamination in the Monument Valley site area.

\subsubsection{Manganese}

\section{Absorption}

Following ingestion, manganese absorption is homeostatically controlled: the rate of absorption depends on both the amount ingested and tissue levels of manganese. For adult humans, approximately 3 to 4 percent of dietary manganese is absorbed (Saric, 1986). Manganese can be absorbed following exposure by inhalation, ingestion, and dermal contact. In humans, available data indicate that only 3 percent of an ingested dose of manganese chloride is absorbed (Mena et al., 1969). Iron and other metals influence the rate of absorption. In states of iron deficiency, manganese is actively absorbed from the intestine. Individuals with anemia can absorb more than twice the percentage of an ingested dose. However, in states of excess iron, manganese absorption is by diffusion only (Saric, 1986). High levels of 
dietary calcium and phosphorus have been shown to increase manganese requirements in several species (Lönnerdal et al., 1987).

\section{Tissue accumulation and clearance}

Manganese is widely distributed throughout the body, with the highest concentrations in the liver and kidneys and, to a lesser extent, the hair. The biological half-time in humans is 2 to 5 weeks, depending on body stores.

Manganese readily crosses the blood-brain barrier and is more slowly cleared from the brain than from other tissues (Goyer, 1991). In the brain, normal concentrations are low, but the half-time is longer and the metal may accumulate with excessive absorption (NRC, 1973).

Absorbed manganese is rapidly cleared from the blood and concentrates in mitochondria. Initial concentrations are greatest in the liver. Manganese penetrates the placental barrier in all species and is more uniformly distributed throughout the fetus than in adult tissues. It is secreted into milk.

Absorbed manganese is almost totally secreted in bile and reabsorbed from the intestine as necessary to maintain body levels. At excessive exposure levels, other gastrointestinal routes may participate. Excess manganese is eliminated in the feces; urinary excretion is negligible (Goyer, 1991; Saric, 1986).

\section{Environmental sources of manganese}

Food constitutes the major source of manganese intake for humans. The highest manganese concentrations are in plants, especially wheat and rice. Drinking water generally contains less than $0.1 \mathrm{mg} / \mathrm{L}$. Manganese levels in soil range from 1 to 7000 milligrams per kilogram (mg/kg), with an average of 600 to $900 \mathrm{mg} / \mathrm{kg}$. Mining and natural geological background variation can contribute to this variability. Manganese bioaccumulates in marine mollusks up to 12,000-fold, and there is evidence for toxic effects in plants (phytotoxicity) and plant bioaccumulation. The Illinois Institute for Environmental Quality recommends criteria of 1 to $2 \mathrm{mg} / \mathrm{kg}$ for manganese in soil and $200 \mathrm{mg} / \mathrm{kg}$ in plants (Saric, 1986).

Differences in eating habits can explain variations in manganese intake. The intake will be higher in populations with cereals and rice as main food sources than in populations where meat and dairy products form a larger part of the diet. The average daily intake is estimated to be between 2.0 and $8.8 \mathrm{mg}$ per day $(0.03$ and $0.13 \mathrm{mg} / \mathrm{kg}$-day) (EPA, 1993), but intakes as high as $12.4 \mathrm{mg}$ (about $0.2 \mathrm{mg} / \mathrm{kg}$-day) have been reported in countries with high cereal intake (Saric, 1986).

Drinking water generally results in an intake of less than $0.2 \mathrm{mg}(0.003 \mathrm{mg} / \mathrm{kg}$-day), although some mineral waters can increase this amount more than threefold (Saric, 1986). One study from Greece reported drinking water concentrations of manganese in excess of $2 \mathrm{mg} / \mathrm{L}$, which would result in daily intakes of approximately 0.06 to $0.07 \mathrm{mg} / \mathrm{kg}$-day (EPA, 1993). 


\section{Manganese toxicity}

Manganese is an essential nutrient. Estimated safe and adequate daily dietary intakes for adults range from 0.03 to $0.07 \mathrm{mg} / \mathrm{kg}$-day (Saric, 1986). The EPA noobserved-adverse-effect level (NOAEL) for drinking water is $0.005 \mathrm{mg} / \mathrm{kg}$-day while the lowest-observed-adverse-effect level (LOAEL) is $0.06 \mathrm{mg} / \mathrm{kg}$-day (EPA, 1993). The EPA RfD for drinking water is $0.005 \mathrm{mg} / \mathrm{kg}$-day. The RfD for food ingestion is $0.14 \mathrm{mg} / \mathrm{kg}$-day. Manganese in drinking water appears to be potentially more bioavailable; i.e., more readily absorbed, than manganese in dietary food sources. This would result in toxic effects with lower ingested doses of manganese in drinking water than in food (EPA, 1993).

Inhalation of manganese in industrial settings has provided the largest source of data on chronic manganese toxicity. These data indicate that excess manganese can result in a central nervous system disorder with symptoms of irritability, difficulty in walking, speech disturbances, and compulsive behavior that may include running, fighting, and singing. With continued exposure, this condition can progress to a mask-like face, retropulsion or propulsion, and a Parkinson-like syndrome. The condition reverses slowly with removal of manganese exposure. Metal chelating agents are ineffective in treatment, but L-dopa has been effective (Goyer, 1991), suggesting that manganese produces functional deficit in the central nervous system.

Limited information is available on the effects of manganese ingestion. Because effects from drinking water seem to differ from those from food sources, only water consumption studies will be considered here. A Japanese study of 25 people drinking well water with manganese concentrations of $14 \mathrm{mg} / \mathrm{L}(0.4 \mathrm{mg} / \mathrm{kg}$-day estimated intake) reported symptoms of intoxication, including a mask-like face, muscle rigidity and tremors, and mental disturbances. Two cases ( 8 percent) of death were reported among intoxicated people. A Greek study of more than 4000 individuals drinking water with manganese concentrations varying from 0.081 to 2.3 $\mathrm{mg} / \mathrm{L}$ (estimated intake at $2 \mathrm{~L}$ per day for a $70-\mathrm{kg}$ individual range from 0.002 to 0.07 $\mathrm{mg} / \mathrm{kg}$-day) showed varying degrees of neurological effects in individuals drinking from 0.007 to $0.07 \mathrm{mg} / \mathrm{kg}$-day, but no effects in individuals drinking less than 0.005 $\mathrm{mg} / \mathrm{kg}$-day (Kondakis et al., 1989).

The chemical form of manganese has complex effects on its toxicity. Although more soluble forms are more readily absorbed from the gastrointestinal tract, they also appear to be more rapidly cleared. Exposure to insoluble forms results in lower manganese absorption, but higher chronic tissue levels and therefore greater toxicity (EPA, 1993). Limited information is available on the effects of various forms of manganese.

Few data are available on manganese toxicity in infants, but infants are probably more susceptible to toxicity due to greater absorption and greater penetration into the central nervous system (EPA, 1993; Saric, 1986).

Figure 5.1 summarizes the health effects of manganese as a function of dose. 


\begin{tabular}{|c|c|c|c|c|c|c|c|c|}
\hline & 1 & $T$ & 1 & $T$ & 1 & & $T$ & \\
\hline 0 & 0.25 & 0.5 & 0.75 & $\begin{array}{c}1.0 \\
\text { (mg/kg-day) }\end{array}$ & 1.25 & 1.5 & 1.75 & 2.0 \\
\hline
\end{tabular}

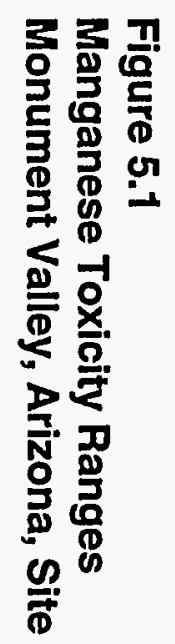

$\triangle$ Background drinking water intake (0.003 $\mathrm{mg} / \mathrm{kg}$-day)

\section{L \\ Dietary intake from food}

$\triangle$ EPA RfD - drinking water ( $0.005 \mathrm{mg} / \mathrm{kg}$-day)

-..-...

Early neurological symptoms

Parkinson-like effects

Acute lethal dose, rodents (400 - $800 \mathrm{mg} / \mathrm{kg}$-day) 


\subsubsection{Nitrate}

\section{Absorption}

Ingested nitrate is converted in the gut to the toxic nitrite ion, which is readily absorbed. The conversion rate depends on both gut flora and $\mathrm{pH}$, with a more rapid conversion occurring in a higher $\mathrm{pH}$ environment. Infants have a higher gut $\mathrm{pH}$, which is more conducive to bacteria growth. Therefore, the combination of a higher $\mathrm{pH}$ and an increased bacterial conversion exacerbates the production of nitrite from nitrate in infants, resulting in higher blood nitrite levels for a given dose of nitrate. In healthy adults, nitrates are rapidly absorbed from the upper intestine. This rapid absorption reduces the contact time with gut flora, thereby reducing the conversion to nitrite and the resultant toxicity.

\section{Tissue accumulation and clearance}

After absorption, the nitrite ion binds to hemoglobin in the blood and oxidizes it, lowering the oxygen-carrying capacity of the blood and decreasing the rate of oxygen release. The oxidized hemoglobin is called methemoglobin and can be reduced back to normal hemoglobin enzymatically by methemoglobin reductase. Infants are more sensitive to these effects because of 1) the presence of fetal hemoglobin, which is more sensitive to oxidation by nitrite; and 2) lower activity of methemoglobin reductase, meaning the methemoglobin remains oxidized for a longer period. Certain individuals have a rare genetic deficiency in methemoglobin reductase and, therefore, exhibit higher levels of circulating methemoglobin. Although these individuals develop alternate metabolic pathways to maintain adequate levels of circulating hemoglobin in the normal state, exposure to high levels of nitrate can result in excessive levels of methemoglobin in these individuals.

In healthy adults, the half-time for methemoglobin reductase conversion of methemoglobin back to hemoglobin is estimated to range from 6 to 24 hours for theoretical levels of methemoglobin in the 80- to 100-percent range (Bolyai et al., 1972).

\section{Environmental sources of nitrate}

Nitrates accumulate in soils from the application of fertilizers, human and animal wastes, bacterial nitrogen fixation, mineral dissolution, and plant and animal tissue breakdown. These nitrates can filter through the soil into ground water. Nitrate concentrations in well water have been reported to exceed $440 \mathrm{mg} / \mathrm{L}$, or 10 times the current regulatory levels (Lee, 1970).

Bioaccumulation of nitrates from soil and water to plants results in a wide range of nitrate concentrations in fresh fruits and vegetables, with levels as high as 2000 $\mathrm{mg} / \mathrm{kg}$ reported in beets and $9000 \mathrm{mg} / \mathrm{kg}$ in radishes (Kamm et al., 1965; Smith, 1966). The accumulation of nitrates in plant material is increased by drought, high temperatures, cloudiness, and insect and herbicide damage to plants. Nitrates and nitrites also are used to preserve meats, especially corned or smoked products. 


\section{Nitrate toxicity}

The primary toxicity of nitrate is methemoglobinemia, which is a function of the balance between circulating levels of nitrite and methemoglobin reductase activity. A very high acute dose can produce the same toxicity as a lower dose that slowly increases the concentration of methemoglobin over time. Therefore, the acute and chronic toxicity of nitrate are summarized together. For easier comparison between ingested doses of nitrate and ground water levels at Monument Valley, dose ranges are presented in terms of nitrate intake. The reader should be aware that nitrate exposure levels are frequently converted to the nitrogen concentration in the nitrate by dividing the nitrate number by 4.4 . Therefore, $44 \mathrm{mg} / \mathrm{L}$ nitrate is equivalent to 10 $\mathrm{mg} / \mathrm{L}$ nitrate-nitrogen.

Symptoms of methemoglobinemia can be correlated with the percentage of methemoglobin in the blood as follows: less than 10 percent, individuals are asymptomatic; more than 25 percent produces weakness, rapid pulse, and tachypnea (rapid breathing); more than 50 to 60 percent can be fatal (EPA, 1993). These symptoms reflect a progressive decrease in oxygen availability. As explained above, infants are more sensitive to methemoglobin production and therefore are considered the most sensitive population. The route of exposure for infants is from contaminated water in formula.

No symptoms of toxicity have been reported with nitrate intakes below $7 \mathrm{mg} / \mathrm{kg}$-day in infants. With intakes from 7 to $30 \mathrm{mg} / \mathrm{kg}$-day, mild symptoms such as weakness, rapid pulse, and rapid breathing occur. The severity of these symptoms increases as increased nitrate intake results in greater levels of methemoglobin and therefore reduced oxygen availability. Cyanosis, or a blue appearance to the skin, occurs, followed by unconsciousness as oxygen availability is further reduced. The lowest reported fatal dose of chronic nitrate is $35 \mathrm{mg} / \mathrm{kg}$-day for an infant and $116 \mathrm{mg} / \mathrm{kg}$ for an adult. A wide range of nitrate intake can produce similar symptoms among individuals because of net differences in gut $\mathrm{pH}$, bacterial activity, and methemoglobin reductase activity. Figure 5.2 summarizes the health effects of nitrates in infants as a function of dose.

Data on nitrate toxicity are primarily based on epidemiologic studies of human adults and infants who report to hospitals with symptoms of methemo-globinemia. In most cases, exposure doses were back-calculated from sampling their drinking water. Therefore, these data do not represent well-controlled studies with readily defined dosage ranges. Many of the water sources in these clinical studies showed contamination with bacteria, leading to the possibility that this bacterial exposure is a necessary cofactor in the development of methemoglobinemia. One laboratory study indicated that healthy infants could drink nitrate at $24 \mathrm{mg} / \mathrm{kg}$-day in solutions free of bacteria and show no symptoms of methemoglobinemia.

Gastrointestinal distress has also been suggested as a cofactor in the development of methemoglobinemia. Anecdotally, infants with colic are more susceptible to nitrate-induced methemoglobinemia. 
Figure 5.2

Nitrate Toxicity Ranges For Infants

Monument Valley, Arizona, Site

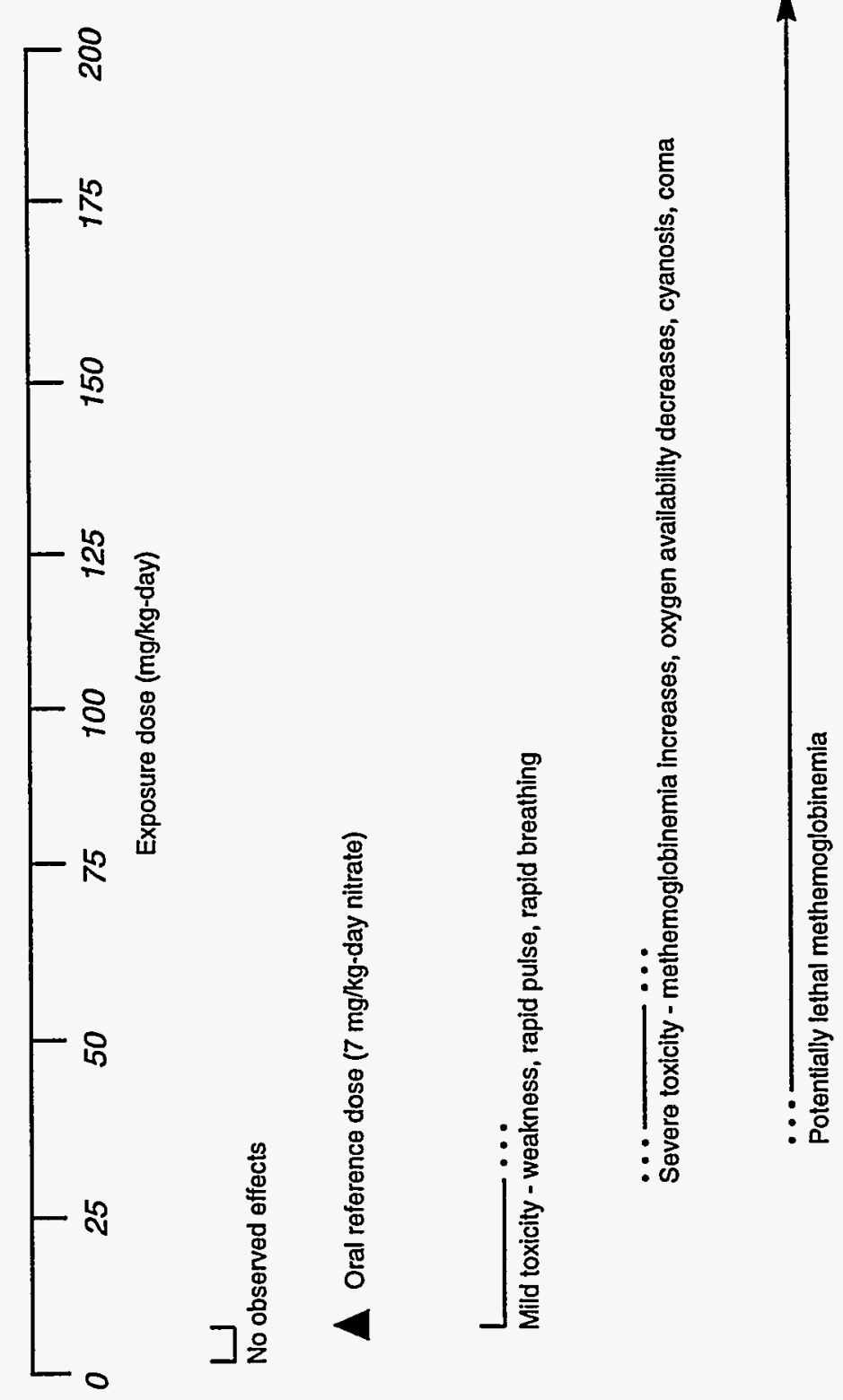




\subsubsection{Strontium}

The isotopes of strontium present at UMTRA Project sites are all natural, stable isotopes. The radioactive element strontium -90 is not naturally occurring and is produced only as a product of fission reactions. Therefore, no radiation exposures are associated with the presence of strontium at UMTRA Project sites.

\section{Absorption}

In humans, 14 to 50 percent of an orally administered dose of strontium is absorbed, with peak blood levels occurring within 4 hours. Absorption is proportional to dose, although large doses may overwhelm homeostatic mechanisms. Strontium is absorbed by passive diffusion from the intestinal lumen (Comar and Wasserman, 1964). Because of their chemical resemblance, strontium can effectively displace calcium. In cases of dietary calcium deficiency, strontium is absorbed to a higher degree. The bioavailability of ingested strontium is estimated to be 20 percent. This figure varies, depending on age, species, form of strontium, and dietary levels of phosphorus, vitamin D, and calcium.

\section{Tissue accumulation and clearance}

Because of its strong similarity to calcium, 99 percent of the body burden of strontium is in bone. The average adult body burden (the amount found in normal, healthy adults) of strontium is estimated to be $320 \mathrm{mg}$ (Snyder et al., 1975). Absorbed strontium is cleared from the body primarily through urine and feces. In humans, 12 to 13 percent of an intravenous dose is eliminated in the feces; urinary excretion eliminates nearly 60 percent of an intravenous dose and 4 to 18 percent of an oral dose (EPA, 1990). Strontium is filtered by the kidneys at a rate 3.5 times greater than calcium (which is reabsorbed more efficiently than strontium), resulting in a more rapid clearance.

\section{Environmental sources of strontium}

Normal dietary intake of strontium in adult humans ranges from 0.013 to $0.021 \mathrm{mg} / \mathrm{kg}$-day. Stable strontium has been reported in drinking water supplies in Wisconsin and Ohio at concentrations ranging from 0.02 to $34.5 \mathrm{mg} / \mathrm{L}$ (Curzon, 1985). Strontium has been used medicinally since 1884, although its medicinal use has steadily declined.

\section{Strontium toxicity}

No data are available on the acute toxicity of stable strontium in humans. In laboratory studies, the range of lethal doses for orally administered strontium varied across species from a lethal dose of $1826 \mathrm{mg} / \mathrm{kg}$ for 50 percent of experimental mice $\left(L D_{50}\right)$ to an $L D_{50}$ of $7500 \mathrm{mg} / \mathrm{kg}$ in rabbits (EPA, 1990). Death resulted from respiratory failure. Intravenous administration decreased the toxic dose by as much as an order of magnitude (148 $\mathrm{mg} / \mathrm{kg}$ in mice). 
No good data are available for estimating toxic effects related to long-term intake of excess stable strontium. Strontium was administered in the treatment of osteoporosis at a dose of $24 \mathrm{mg} / \mathrm{kg}$-day for as long as 3 years (EPA, 1993). Although no side effects were observed, the resultant bone loss renders questionable the extrapolation of these data to a healthy population.

In rat studies, strontium toxicity is related to its calcium displacement in bone; this toxicity differs with the developmental stage of the animal. The lowest intake level producing toxicity in young rats was $380 \mathrm{mg} / \mathrm{kg}$-day of strontium carbonate. This dose inhibited calcification of the epiphyseal plate after 3 weeks of exposure. In adult rats, this dose had no effect, but a much larger epiphyseal plate was observed following intake of 750 or $1500 \mathrm{mg} / \mathrm{kg}$-day in the adult animals (Storey, 1961). Intake of $190 \mathrm{mg} / \mathrm{kg}$-day resulted in no observed toxicity in the young rats. In weanling rats, drinking $633 \mathrm{mg} / \mathrm{kg}$-day of strontium chloride in water resulted in slower mineralization of the bone, slower calcification, and defective long bone growth (Marie et al., 1985). No toxicity was observed in the weanling animals at $525-\mathrm{mg} / \mathrm{kg}$-day intake of strontium chloride. Figure 5.3 summarizes these health effects as a function of dose.

\subsubsection{Sulfate}

\section{Absorption}

Sulfate absorption from the gastrointestinal tract is similar between humans and other mammals. Generally, greater than 90 percent absorption is reported for sulfate doses below $150 \mathrm{mg} / \mathrm{kg}$, decreasing to 50 to 75 percent as the dose increases into the grams per kilogram range.

\section{Tissue accumulation and retention}

Ingestion of high levels of sulfate results in transient increases in both blood and urine concentrations. For sulfate doses of approximately $75 \mathrm{mg} / \mathrm{kg}$, an estimated 50 percent of the dose is excreted over 72 hours. The urinary excretion mechanism is transport-limited and can therefore become saturated at high doses of sulfate. Excess sulfate also is excreted in feces in its inorganic form. To date, no available data indicate sulfate is accumulated, even with chronic ingestion of above-normal levels. However, no extremely high chronic doses appear to have been examined in humans.

Sulfate is used in the biosynthesis of collagen, cartilage, and dentin and in the formation of sulfate esters of both endogenous compounds (such as lipids and steroids) and exogenous compounds (such as phenols). Sulfation is important in detoxication pathways because it increases the solubility of these compounds, which enhances their excretion in the urine. Exposure to high concentrations of compounds that are conjugated with sulfate and excreted can produce a transient decrease in sulfate concentrations in plasma. 


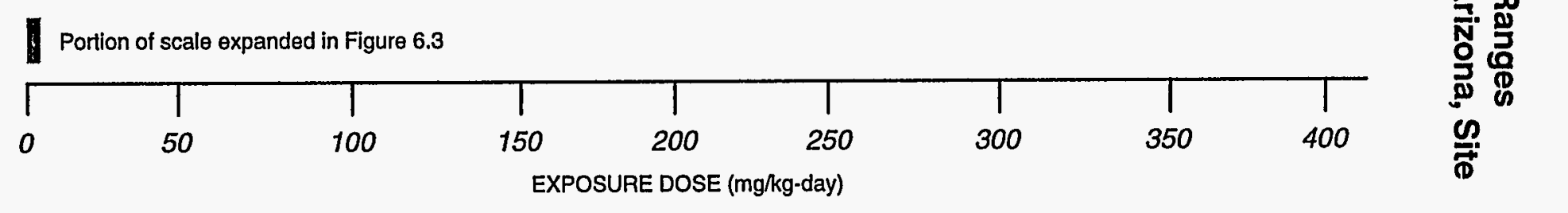

\ Dietary intake levels

$\triangle$ Oral reference dose (0.6 mg/kg-day)

No observed side effects in treated humans

No observed effects in young rats

… • • •

Mild toxicity (rats) 


\section{Environmental sources of sulfate}

Drinking water in the western United States in 1978 showed a range of sulfate concentrations from 0 to $820 \mathrm{mg} / \mathrm{L}$, with a mean sulfate concentration of $99 \mathrm{mg} / \mathrm{L}$. The EPA estimates a normal sulfate intake range of 0.00023 to $0.0064 \mathrm{mg} / \mathrm{kg}$-day from air and up to $2.9 \mathrm{mg} / \mathrm{kg}$-day from drinking water in the concentration range in the western United States (EPA, 1992b). No estimates are available on sulfate intake from food sources.

\section{Sulfate toxicity}

As with nitrate toxicity, the acute and chronic effects of sulfate toxicity differ more in severity than in symptoms or mechanisms. Therefore, this discussion combines acute and chronic toxicity. As mentioned above, no available data indicate bioaccumulation of sulfate with chronic exposure. Sulfate salts of magnesium and sodium are used medicinally as cathartics. The presence of high concentrations of . unabsorbed sulfate salts in the gut can pull large amounts of water into the gut, greatly increasing the normal volume of feces. This is the basis of the toxic effects as well.

Toxicity in humans primarily manifests itself in diarrhea. Serious gastroenteritis has been reported in some infants and adults drinking water containing 400 to 1000 $\mathrm{mg} / \mathrm{L}$ sulfate (EPA, 1992b). The severity of the diarrhea is dose-dependent. Chronic ingestion of sulfate can result in persistent diarrhea, leading to ionic imbalances and dehydration similar to that seen with extremely high, acute doses. However, this is not necessarily the case. In regions such as Saskatchewan, with high sulfate concentrations in the drinking water, residents adapt to the taste and find the water palatable (EPA, 1992b). When drinking water is contaminated with sulfate, the taste of the water may make it unpalatable and reduce consumption. Also, data indicate diabetic and elderly populations with compromised kidney function may be more sensitive to the effects of sulfates than are healthy adults (EPA, 1992b). This lower water intake could compound the dehydration effects of the diarrhea which, in extreme cases, can lead to death. As with nitrate toxicity, infants may be the most susceptible population for sulfate-induced diarrhea. Figure 5.4 summarizes these health effects as a function of dose.

In cattle, high sulfate intake has resulted in sulfhemoglobinemia, a condition similar to the methemoglobinemia induced by nitrate ingestion (EPA, 1992b). No cases of sulthemoglobinemia have been reported following sulfate ingestion by humans, although the condition has been reported in humans following hydrogen sulfide inhalation.

As with nitrate, data on sulfate toxicity are based primarily on epidemiologic studies of human adults and infants who report to hospitals with symptoms of sulfate exposure. In most cases, exposure doses were back-calculated from sampling their drinking water. Therefore, these data do not represent well-controlled studies with readily defined dosage ranges. 


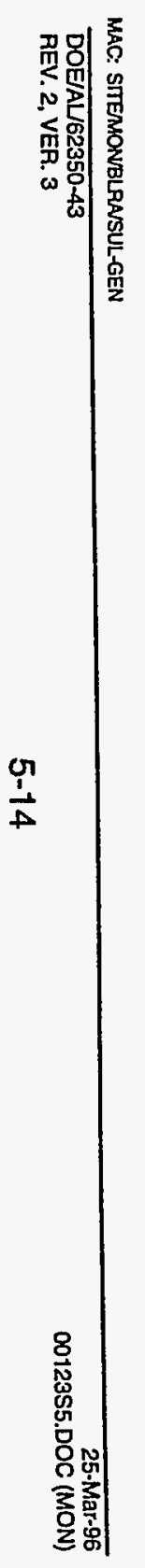

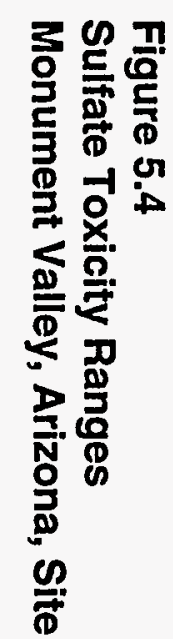

$\sqcup$

Background intake levels

ᄂ....

No observed effects

Mild toxicity ranging from laxative effect

from laxative effect (adults) to diarrhea in infants

Severe toxicity - persistent infant diarrhea leading to dehydration $\ldots . . . . . . . . . . . . . .-$ death 


\subsubsection{Uranium}

The naturally occurring uranium present at UMTRA Project sites consists of three radioactive isotopes: uranium-234, uranium-235, and uranium-238. More than 99 percent of natural uranium occurs in the form of uranium-238 (Cothern and Lappenbusch, 1983). Uranium-238 undergoes radioactive decay by emitting alpha particles to form uranium-234, thorium-230, radium-226, radon-222, polonium-210, and other radioisotopes with shorter half-lives. Figure 5.5 summarizes the radioactive decay chain of uranium-238 and uranium-234. As all uranium isotopes in nature are radioactive, the hazards of a high uranium intake are from both its chemical toxicity and its potential radiological damage. This section focuses on the chemical toxicity of natural uranium. Section $\mathbf{5 . 1}$ discusses the carcinogenic potential associated with exposure to radioactive isotopes of natural uranium.

\section{Absorption}

Absorption of uranium in the gastrointestinal tract depends on the solubility of the uranium compounds. The hexavalent uranium compounds, especially the uranyl salts, are water soluble, while tetravalent compounds generally are not (Weigel, 1983). Even with soluble compounds, only a small fraction is absorbed. Human gastrointestinal absorption rates of 0.76 to 7.8 percent have been determined (Wrenn et al., 1985).

\section{Tissue accumulation and clearance}

In humans exposed to background levels of uranium, the highest concentrations were found in bone, muscle, lung, liver, and kidney (Fisenne et al., 1988). Uranium retention in bone consists of a short retention half time of 20 days followed by a long retention half time of 5000 days for its residue (Tracy et al., 1992).

In body fluids, uranium tends to convert into water-soluble hexavalent uranium (Berlin and Rudell, 1986). Approximately 60 percent of the uranium in plasma complexes with low-molecular-weight anions (e.g., bicarbonates, citrates), while the remaining 40 percent binds to the plasma protein transferrin (Stevens et al., 1980). Following oral exposure in humans, more than 90 percent of uranium is excreted in the feces and not absorbed in the gastrointestinal tract. Of the small percentage absorbed (typically less than 5 percent), approximately 60 percent is excreted in the urine within 24 hours and 98 percent is excreted within 7 days. These data are based on animal studies by Ballou et al. (1986), Leach et al. (1984), and Sullivan et al. (1986). A small portion of the absorbed uranium is retained for a longer period.

\section{Environmental sources of uranium}

Uranium is an ubiquitous element, present in the earth's crust at approximately 4 parts per million. Uranium concentrations in samples of ground water and surface water worldwide averaged $1 \mathrm{pCi} / \mathrm{L}$ and $3 \mathrm{pCi} / \mathrm{L}$, respectively (NCRP, 1984). It is absorbed from the soil into plant tissues to an extent that depends on the plant species and the depth of its root system (Berlin and Rudell, 1986). Plant 
Figure 5.5

Half-lives And Radiation Emission Patterns

Resulting From Decay Of Uranium-238

Monument Valley, Arizona, Site
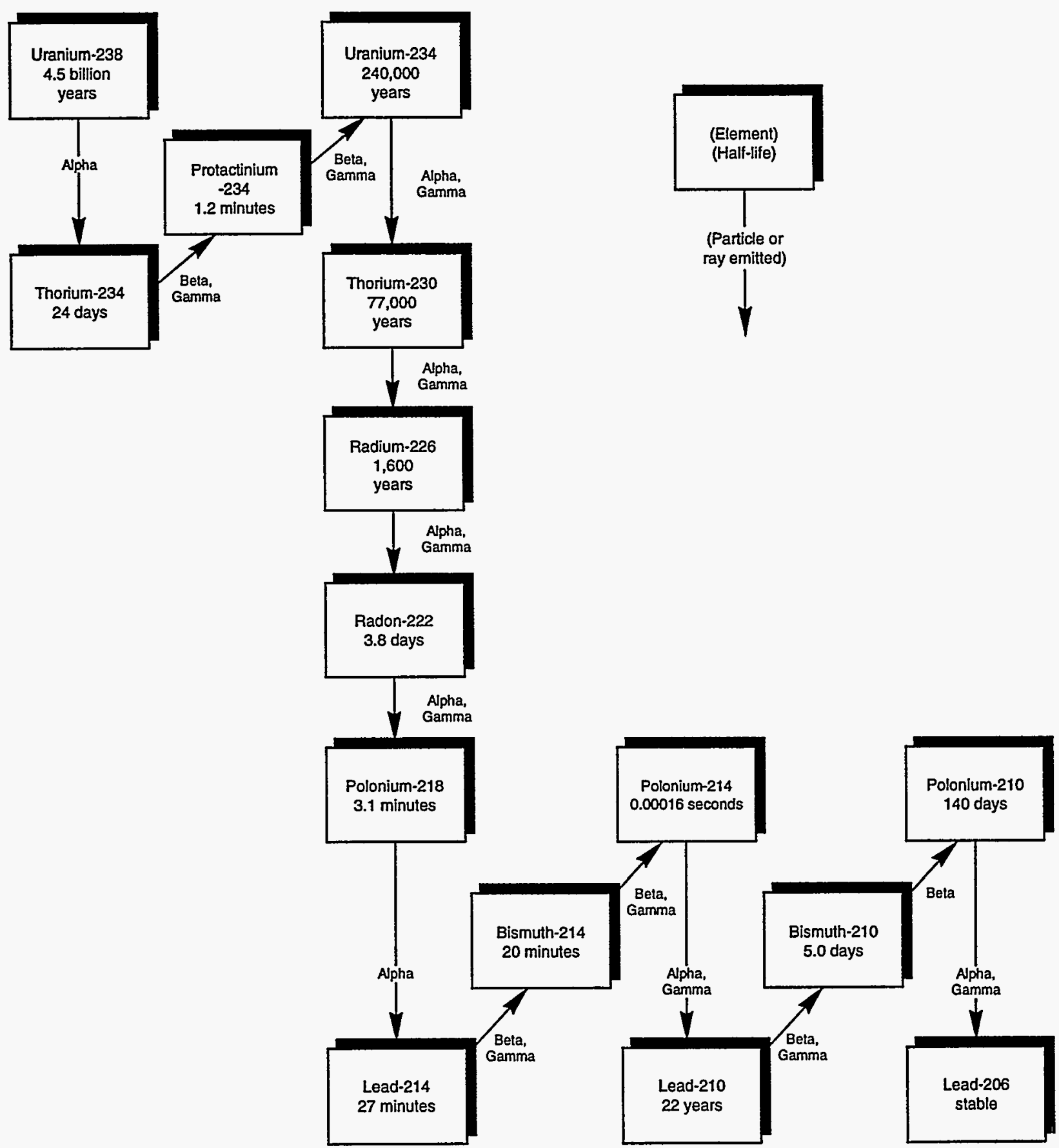

MAC: STIEMONBLRAHALF-LVES 
concentrations of uranium averaged 0.075 micrograms per kilogram $(\mu \mathrm{g} / \mathrm{kg})$ fresh plant material (Tracy et al., 1983).

The main dietary source of natural uranium for the general population is from bakery goods, potatoes, meat, and fresh fish, which may contain uranium concentrations between 10 and $100 \mu \mathrm{g} / \mathrm{kg}$ (Prister, 1969). The total dietary uranium intake from the consumption of average foods is approximately $1 \mu \mathrm{g}$ per day; additionally, approximately 20 to 50 percent of this total can come from drinking water. Cereals and vegetables, particularly root crops, probably contribute most to the daily uranium intake (Berlin and Rudell, 1986).

\section{Uranium toxicity}

Exposure of the general public to natural uranium is unlikely to pose an immediate lethal threat to humans. No human deaths reported have been definitely attributable to uranium ingestion; therefore, no lethal dose has been determined for humans. Lethal doses of uranium ( $L D_{50,23}$ ) have been reported to be as low as $14 \mathrm{mg} / \mathrm{kg}$-day following 23-day oral exposures, depending on both the solubility of the uranium compound (higher solubility compounds have greater toxicity), route of exposure, and the animal species tested. High uranium doses cause complete kidney and respiratory failure.

No chronic toxic effects have been reported in humans following oral exposure to uranium. Data available from populations occupationally exposed to high concentrations of uranium compounds through inhalation and from studies on experimental animals indicate that the kidney is the critical organ for chronic uranium toxicity, specifically the proximal tubule (Friberg et al., 1986). In humans, chemical injury reveals itself by increased catalase excretion in urine and proteinuria. Dose-response data for the toxic effect of uranium on the human kidney are limited.

The lowest dose of uranyl nitrate to cause moderate renal damage was given to rabbits in their diet at $2.8 \mathrm{mg} / \mathrm{kg}$-day (Maynard and Hodge, 1949). Figure 5.6 summarizes the health effects of uranium as a function of dose.

\subsubsection{Vanadium}

\section{Absorption}

Absorption of vanadium from the gastrointestinal tract is low. The ICRP (1960) estimate for the absorption of soluble vanadium compounds is 2 percent, but the World Health Organization maintains that absorption of even very soluble forms of vanadium is less than 1 percent from the gastrointestinal tract (WHO, 1988). Limited human studies (three individuals) suggest that as much as 10 percent of a repeated oral dose may be absorbed (Proescher et al., 1917; Tipton et al., 1969). Soluble vanadium compounds that are inhaled and deposited are more readily absorbed (approximately 25 percent) (WHO, 1988). Although soluble forms of vanadium may be absorbed through the skin, absorption is probably minimal (EPA, 1977; WHO, 1988). 
Portion of scale expanded in Figure 6.5

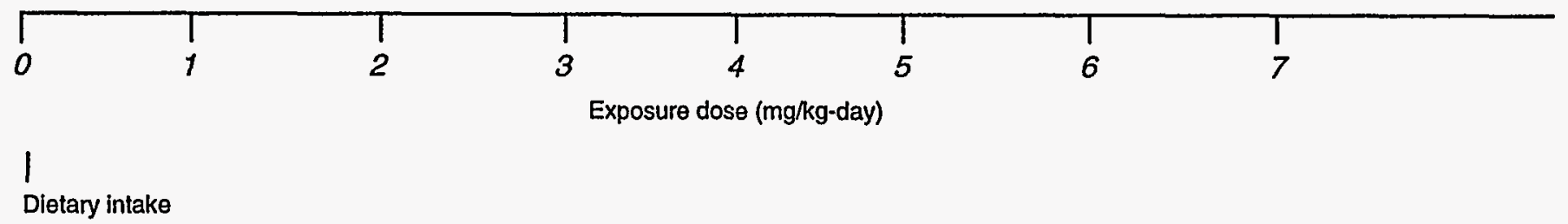

Aral reference dose $(0.003 \mathrm{mg} / \mathrm{kg}$-day $)$

…..

Reversible kidney impairment after acute human exposure

(based on dose reconstruction, case study)

No observed effects in either mice or rats

(sufficient human data not available)

$$
\begin{aligned}
& \text { Mild toxicity } \\
& \text { (rabbits, renal damage) }
\end{aligned}
$$




\section{Tissue accumulation and clearance}

Vanadium is found in all body tissues in concentrations ranging from $0.08 \mu \mathrm{g}$ per gram wet weight in spleen tissue to $0.14 \mu \mathrm{g}$ per gram in brain and heart tissue and $0.33 \mu \mathrm{g}$ per gram in aorta tissue (Yakawa and Suzuki-Yasumoto, 1980). Vanadium concentrations in human blood serum are reported to be 0.016 to 0.939 nanograms per milliiter $(\mathrm{ng} / \mathrm{mL})$. Different authors report vanadium concentrations in hair ranging from 20 to $60 \mathrm{ng}$ per gram, with higher values found in manic-depressive patients than in normal control groups ( 57 versus 29 ng per gram, respectively).

The distribution of vanadium in humans following oral exposure may be extrapolated from animal studies. In acute-duration exposures, vanadium is rapidly distributed, primarily in the bones. After intermediate-duration exposure, vanadium concentrations reaching the tissues are low, with the kidneys, bones, liver, and lungs initially showing the highest levels.

Vanadium is an element and is not metabolized. However, in the body, there is an interconversion of two oxidation states of vanadium: vanadyl and vanadate. Vanadium can reversibly bind with the protein transferrin in the blood and then be taken up into erythrocytes. There is a slower uptake of vanadyl into erythrocytes compared to the vanadate form, possibly due to the time required for the vanadyl form to be oxidized to vanadate. Initially, vanadyl leaves the blood more rapidly than vanadate, possibly due to the slower vanadyl uptake into cells (Harris et al., 1984). Five hours after administration, blood clearance is essentially identical for the two forms. Vanadate is the dominant species of vanadium in ground water at the Monument Valley site.

Because vanadium is poorly absorbed in the gastrointestinal tract, a large percentage of vanadium in rats is excreted unabsorbed in the feces following oral exposure. In rats, the principal route of excretion of the small absorbed portion of vanadium is through the kidneys. The mean urinary output per 24 hours is reported to be $10 \mu \mathrm{g}$.

\section{Environmental sources of vanadium}

Elemental vanadium does not occur in nature, but its compounds exist in more than 50 different mineral ores and in association with fossil fuels. The single largest release of vanadium to the atmosphere occurs through the combustion of fossil fuels, particularly residual fuel oils. The largest amount of vanadium released to soil and water occurs through the natural weathering of geological formations (Byerrum et al., 1974; Van Zinderen Bakker and Jaworski, 1980).

Food constitutes the major source of vanadium exposure for the general population (Lagerkvist et al., 1986). Dietary intake is estimated to be 6 to $18 \mu \mathrm{g}$ per day (Pennington and Jones, 1987), although estimates from older studies using different (and possibly less sensitive) analytical methods have been as high as $2 \mathrm{mg}$ per day (Schroeder et al., 1963). 
Drinking water is not considered an important source of vanadium exposure for the general population. Water samples from across the United States show 92 percent with values below 10 micrograms per liter $(\mu \mathrm{g} / \mathrm{L})$. Typical values appear to be around $1 \mu \mathrm{g} / \mathrm{L}$ (Lagerkvist et al., 1986). The estimated daily intake of vanadium by inhalation is $1 \mu \mathrm{g}$ (Byrne and Kosta, 1978).

Although vanadium is considered an essential element for chickens and rats, human dietary requirements are uncertain. For animals, the daily requirement is about 10 to $25 \mu \mathrm{g}$ per day (Pennington and Jones, 1987).

\section{Vanadium toxicity}

The major adverse health effect to humans from vanadium is seen in workers exposed to large amounts of vanadium pentoxide dusts. The probable oral lethal dose of vanadium pentoxide for humans is between 5 and $50 \mathrm{mg} / \mathrm{kg}$ (Gosselin et al., 1976).

Systemic effects of vanadium exposure have been observed in the liver, kidneys, nervous and cardiovascular systems, and blood-forming organs. Metabolic effects include interference with the biosynthesis of cystine and cholesterol, depression and stimulation of phospholipid synthesis, and, at higher concentrations, inhibition of serotonin oxidation. Other effects of vanadium on mammalian metabolism include depression of phospholipid synthesis (Snyder and Cornatzer, 1958), reduction of coenzyme Q levels in mitochondria (Aiyar and Sreenivasan, 1961), and stimulation of monoamine oxidase, which oxidizes serotonin (Perry et al., 1955).

Vanadium salts were given to patients in several studies to reduce cholesterol levels (Curran et al., 1959; Somerville and Davies, 1962; Dimond et al., 1963; Schroeder et al., 1963). The doses of vanadium in these studies varied from 7 to $30 \mathrm{mg}$ per day. Transient decreases in serum cholesterol levels were observed in some patients, as were loosened stool and cramps. Green tongue, a hallmark of vanadium exposure, was observed in all patients.

Tank and Storvick (1960) report a relationship between the concentration of vanadium in drinking water and the incidence of dental caries in children. Dental caries incidence in children aged 7 to 11 years was reduced three times (compared to controls) by applying ammonium vanadate in glycerol to the teeth (Belehova, 1969). Other studies (Hadjimarkos, 1966; 1968) did not find this relationship.

It has been suggested that raised tissue levels of vanadium are important in the etiology of manic-depressive illness. Both manic and depressed patients improved after treatment with ascorbic acid or reduced vanadium intake.

Although animal studies have reported impaired conditioned reflexes following doses of vanadium from 0.05 (6 months) to 0.5 ( 21 days) $\mathrm{mg} / \mathrm{kg}$-day, effects on the nervous system have not been reported following repeated oral vanadium administration in humans. Workers exposed by inhalation to fairly high concentrations of vanadium compounds (milligrams per cubic meter) report nonspecific symptoms, including headache, weakness, vomiting, nausea, and 
ringing of the ears (WHO, 1988). Available data on vanadium toxicity are insufficient to evaluate effects on cholesterol levels, iron metabolism, blood cell production, and mutagenesis. However, due to poor absorption from the gut, the metal is not considered very toxic following oral administration (WHO, 1988).

Figure 5.7 summarizes the health effects of vanadium as a function of dose. 
Figure 5.7

Vanadium Toxicity Ranges

Monument Valley, Arizona, Site
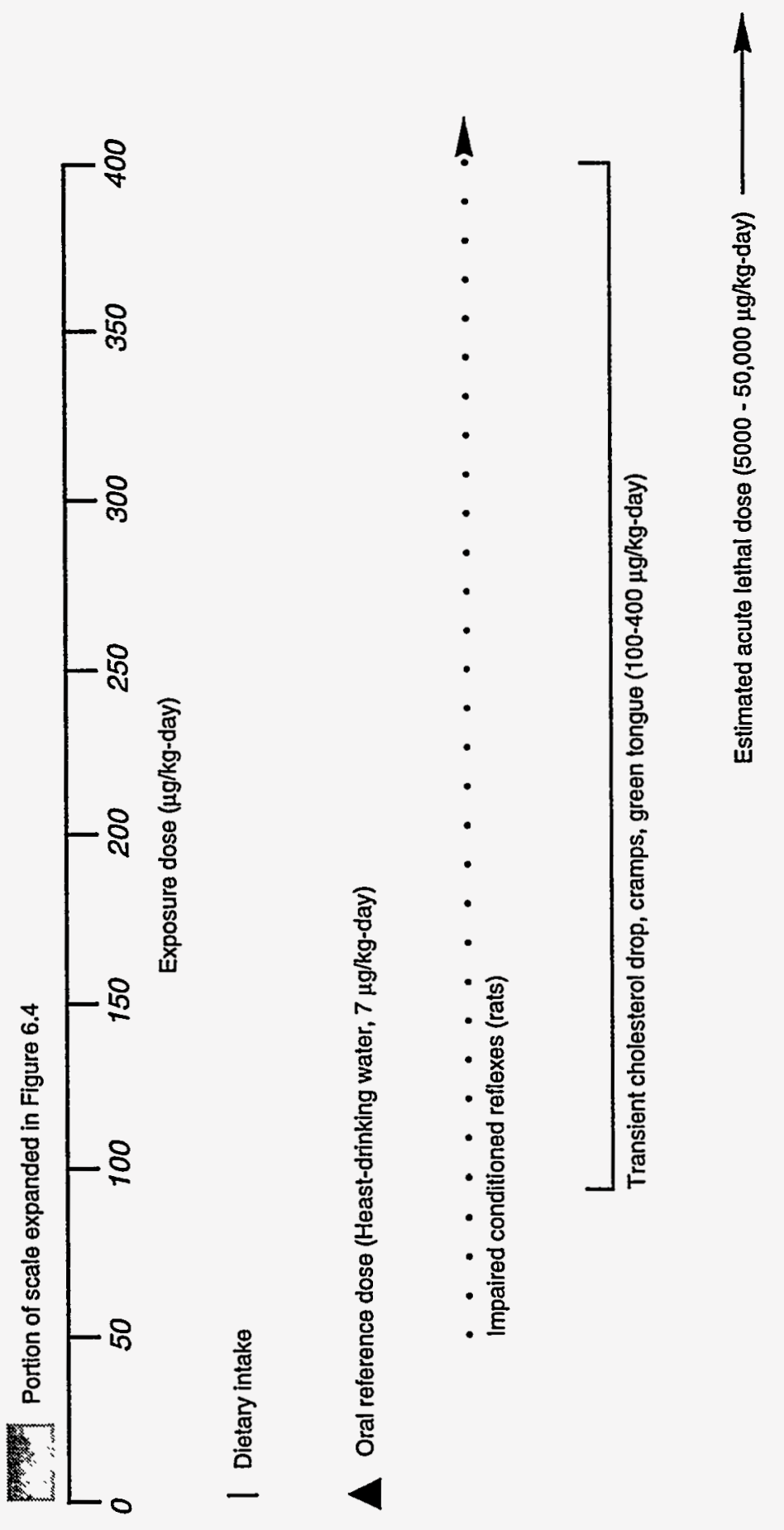


\subsection{RISK EVALUATION}

To evaluate human health risks to an individual or population, the results of the exposure assessment are combined with the results of the toxicity assessment. As discussed in Section 5.0, potential adverse health effects are a function of how much of the constituent an individual takes into his or her body. Indeed, at lower levels some of the constituents_associated with the mill tailings are beneficial to health because they are essential nutrients. At higher levels, these same constituents can cause adverse health effects. In this section, the potential intakes (if ground water within the plume were used as drinking water) are correlated to potential adverse health effects from these levels of exposure.

\subsection{POTENTIAL NONCARCINOGENIC HEALTH EFFECTS}

The results from the exposure assessment showing either the highest intake-tobody-weight ratios (or highest doses) or the toxicologically most sensitive group are used to evaluate potential health effects for noncarcinogens. For manganese, strontium, uranium, and vanadium, the highest intake-per-bodyweight group is children 1 to 10 years old. For nitrate and sulfate, infant exposures are used to evaluate health risks because this is the most toxicologically sensitive population.

The most significant potential health risk associated with drinking contaminated ground water at the Monument Valley mill site is from nitrate. As seen in Figure 6.1, more than 50 percent of the expected exposures would be above the potentially lethal level for infants. Some degree of methemoglobinemia is expected with any consumption of ground water by infants, with more than 70 percent of the predicted exposure range falling above the severe toxicity level.

The levels of nitrate associated with lethal cases of methemoglobinemia vary considerably. A major cofactor in nitrate toxicity may be the presence of bacterial contamination of the ground water, thus increasing reduction to nitrite in the gut. This factor has not been evaluated in Monument Valley ground water. A second significant factor is that infants prone to gastrointestinal distress seem more sensitive to the toxic effects of nitrates. For this reason, the gastrointestinal effects associated with sulfate exposures could increase nitrate toxicity. However, sulfate-induced diarrhea also could decrease the intestinal content of nitrate-reducing bacteria, making nitrate less toxic. Likewise, these high sulfate concentrations may cause the water to be unpalatable to infants, thus reducing their exposure.

Figure 6.2 shows that much of the exposure distribution for sulfate is above the range where mild diarrhea is expected and nearly 50 percent of the exposures are above the range of severe diarrhea. The contribution from the dermal absorption pathway would not alter the interpretation of health risks for either nitrate or sulfate. 


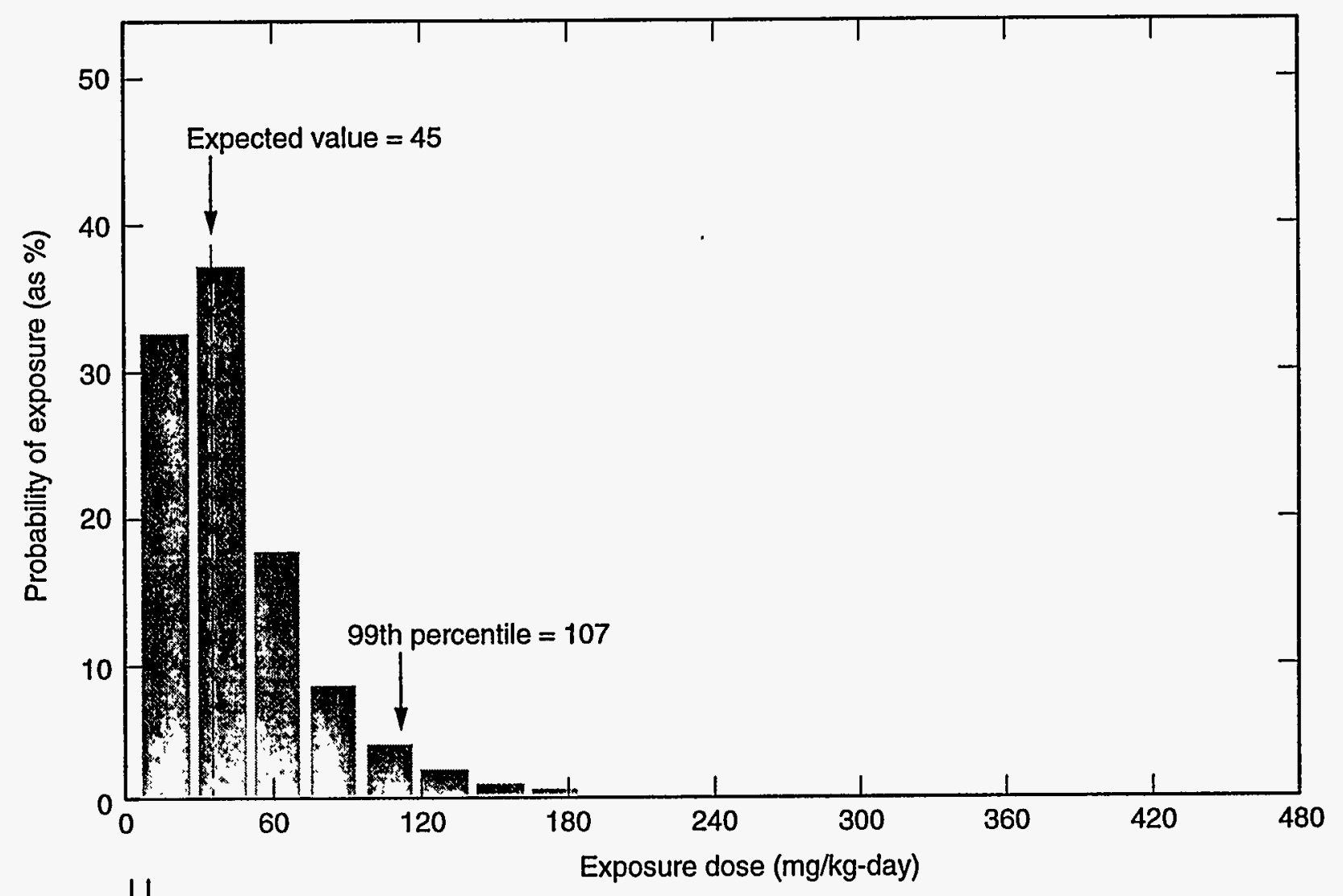

ப

No observed effects

Oral reference dose (7 mg/kg-day nitrate)

L...

Mild toxicity -- weakness, rapid pulse, rapid breathing

Severe toxicity - methemoglobinemia increases, cyanosis, coma

Potentially lethal methemoglobinemia

Note: Severe toxic effects and potentially lethal methemoglobinemia would result from the majority of predicted infant exposures. 


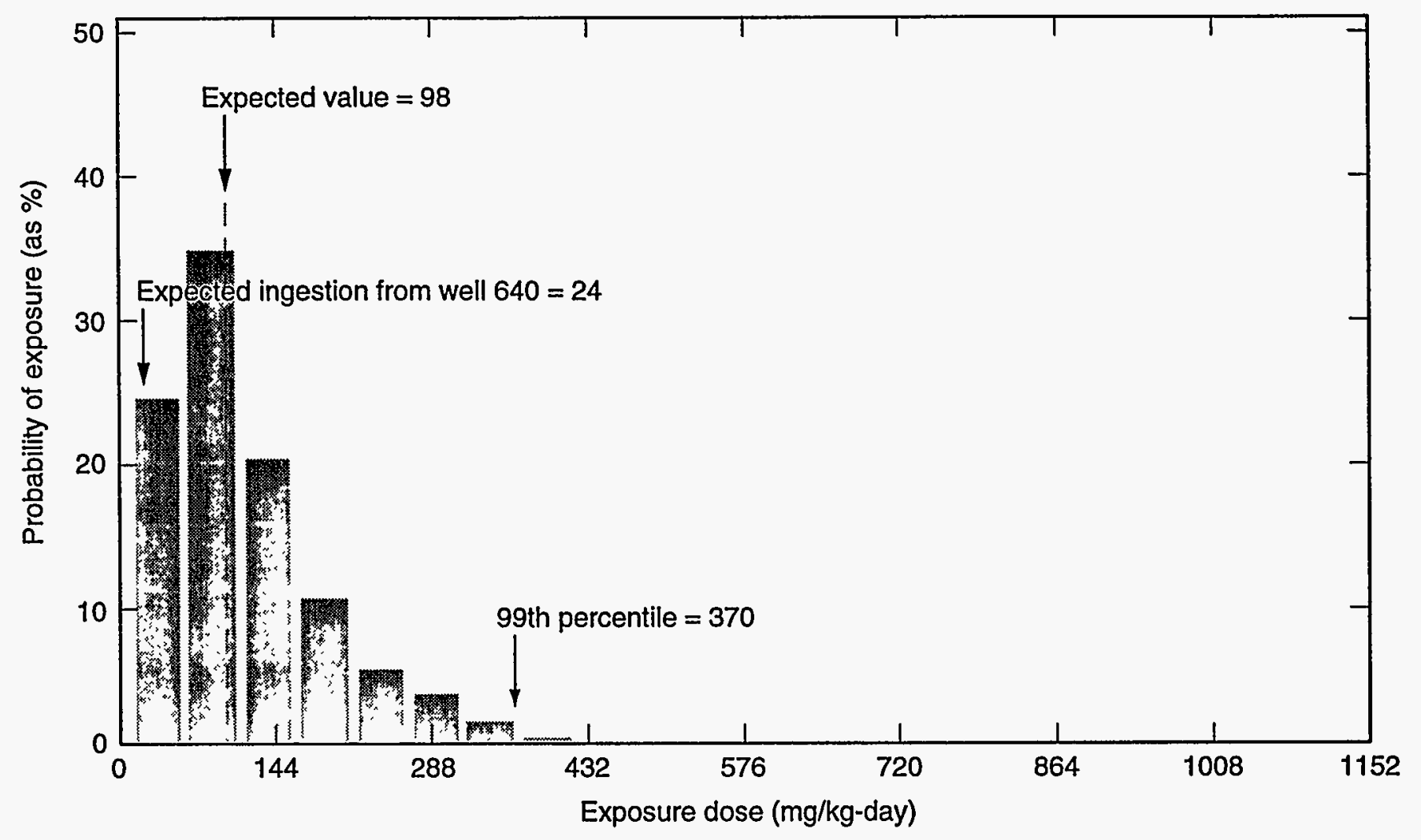

$\sqcup$

Background intake levels

L...

No observed effects

Mild toxicity ranging from laxative effect to diarmea in infants

Severe toxicity -- persistent infant diarrhea leading to dehydration

Note: Laxalive effects manifested as diarrhea in infants could occur even within the lower range of predicted exposures, with severe dehydration in infants occurring at higher predicted exposures 
It is important to note that the exposure distribution for infants is based on tap water intake rates across a population that includes breast-fed and canned formula-fed infants. Those infants consuming powdered formula reconstituted with well water would be in the upper percentiles of this exposure distribution and could be at high risk for severe diarrhea and methemoglobinemia.

Furthermore, these effects are expected after very short-term exposures.

The predicted exposure to manganese from ingestion of contaminated ground water exceeded the EPA RfD (Figure 6.3) for drinking water in 35 percent of the cases. These predicted exposures could produce neurological symptoms similar to those seen in the early stages of Parkinson's disease, but these symptoms are slowly reversible after manganese exposure ceases (Section 5.1.1). There has been a suggestion that infants may be more sensitive to manganese toxicity than data shown here indicate, but data to evaluate that possibility are not available.

For the remaining constituents of potential concern at Monument Valley, adverse effects are not anticipated from chronic ground water ingestion. For strontium (Figure 6.4) and vanadium (Figure 6.5), more than 99 percent of the exposure distribution falls below the EPA-derived oral RfD, and the remaining portion of these distributions is well below any toxic effects observed in humans. For uranium (Figure 6.6), more than 95 percent of the predicted exposure range is below the EPA oral $\mathrm{RfD}$, and the entire distribution is well below any toxic effects in humans. The added dose from the dermal contact exposure route would not significantly contribute to the total toxicity potential at this site.

Diabetics and the elderly may be more sensitive to uranium toxicity due to their already impaired kidney function. The incidence of type II (adult onset) diabetes in Navajos is approximately 20 percent in members of the population more than 20 years old and appears to be increasing (Hoy, 1993). Compromised renal function and increased drinking water ingestion rates in this diabetic subpopulation could increase susceptibility to toxicants. Though insufficient data exist to allow this risk assessment to quantitatively evaluate risk to diabetics, it is recognized that this group could represent a sensitive subpopulation. Therefore, toxic effects may appear in sensitive individuals at lower levels than those presented in Section 5.0.

\subsection{POTENTIAL CARCINOGENIC HEALTH EFFECTS}

All uranium isotopes are radioactive and, as such, are considered potential carcinogens. Figure 6.7 shows the exposure distribution for uranium intake and the potential lifetime carcinogenic risk associated with these drinking water exposures. These estimates are based on the cancer slope factor developed by the EPA; however, natural uranium has not been demonstrated to cause cancer in humans or animals following ingestion exposures. More than 99 percent of the exposure distribution for ground water ingestion of uranium falls below the National Contingency Plan (NCP) guidance for maximum increased lifetime 

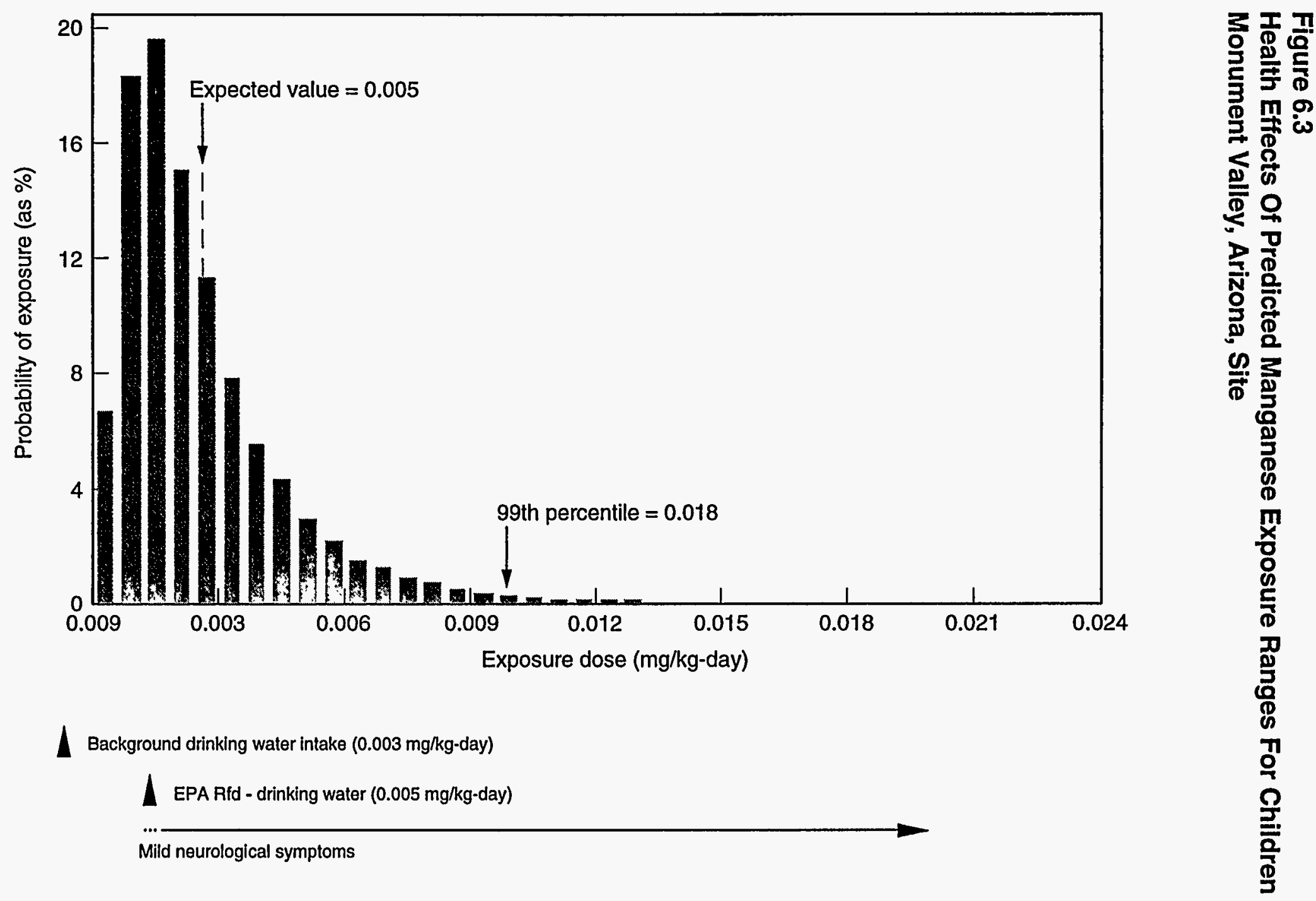

Note: Mild neurological symptoms have been associated with the upper half of the predicted exposure range. 
Figure 6.4

Health Effects Of Predicted Strontium Exposure Ranges For Children

Monument Valley, Arizona, Site

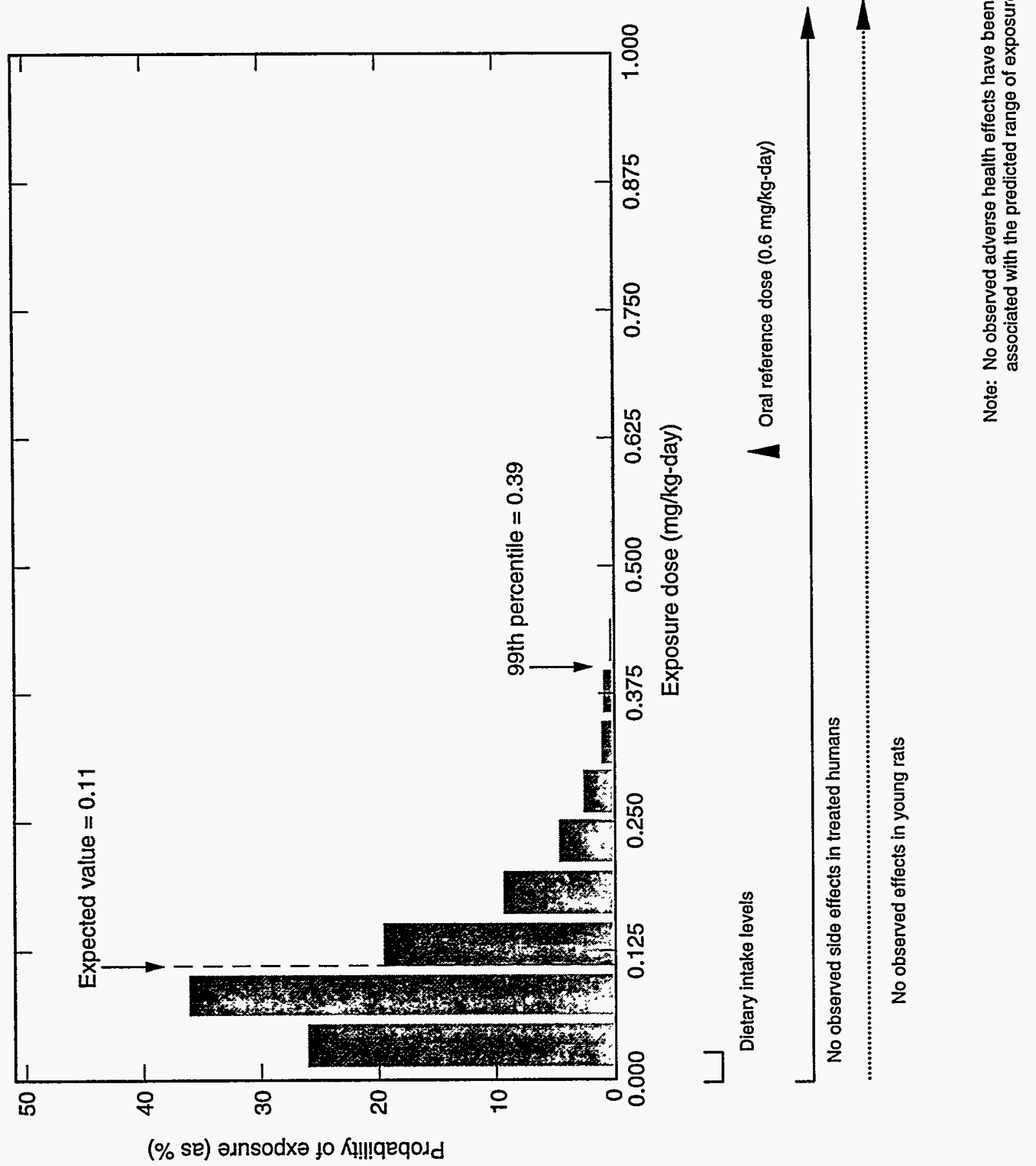



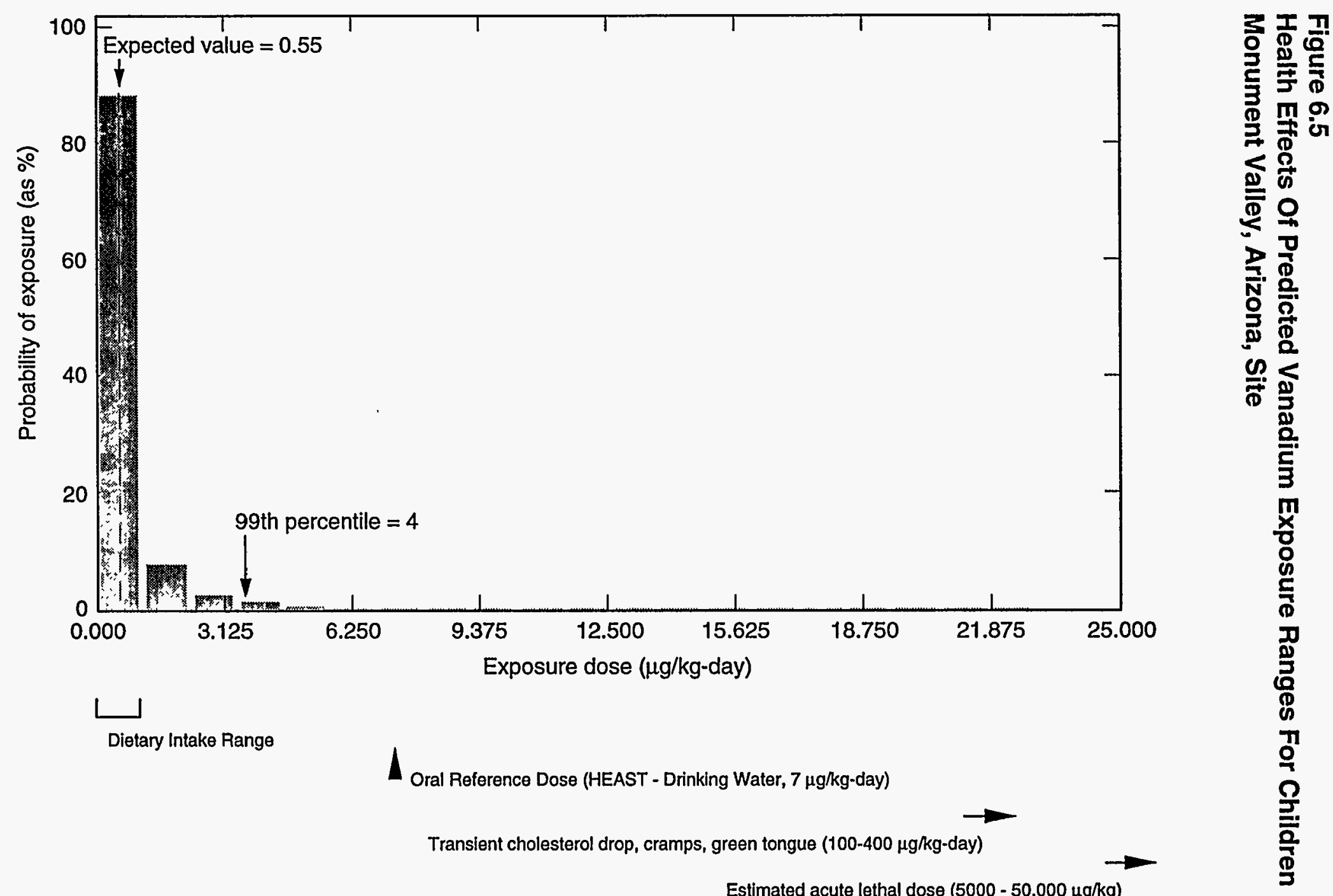

Note: No observed adverse health effects have been associated with the predicted range of exposures. 
Figure 6.6

Health Effects Of Predicted Uranium Exposure Ranges For Children Monument Valley, Arizona, Site

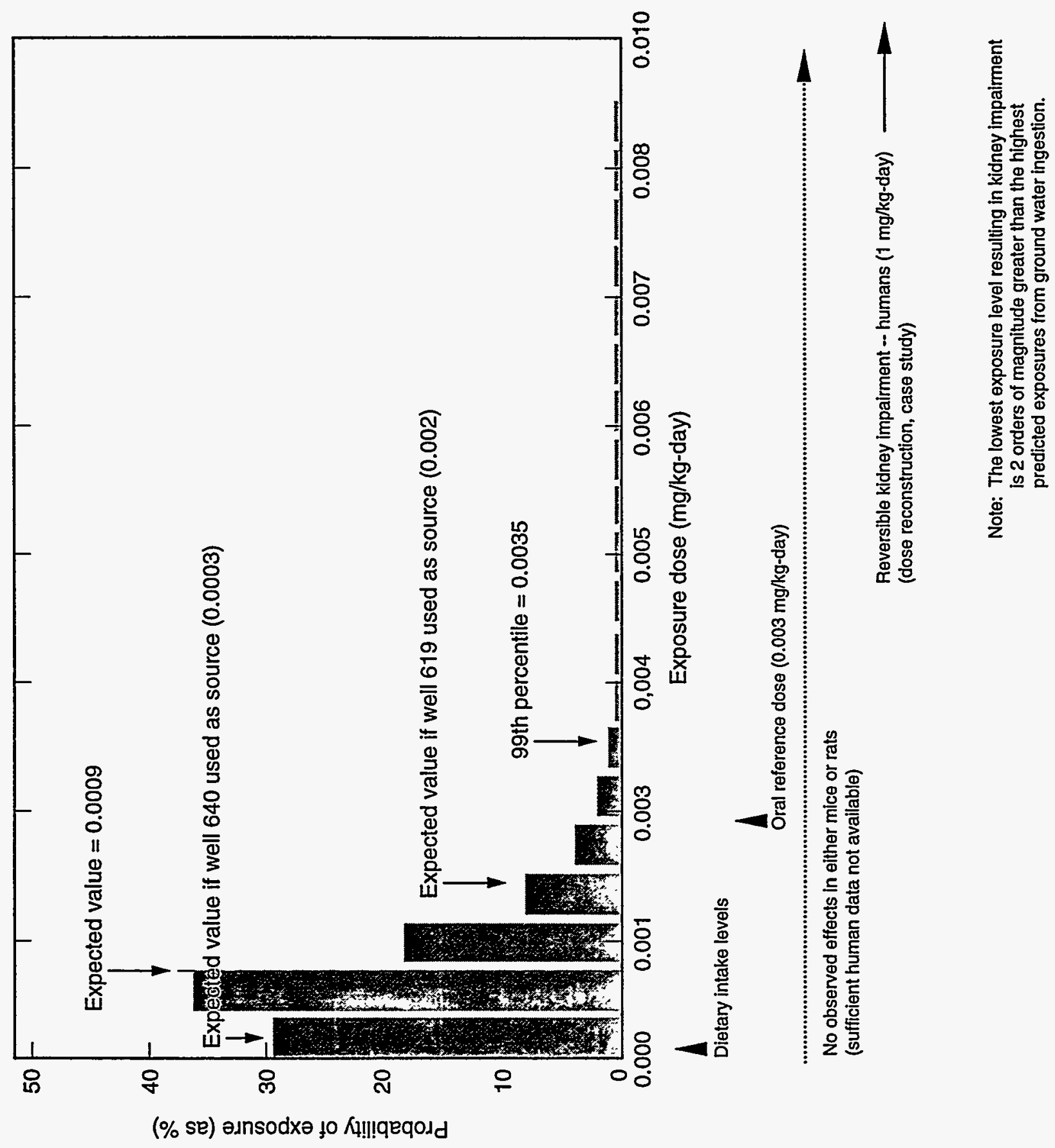


Figure 6.7

Increased Lifetime Cancer Risk Associated With Predicted Radiation Exposures Resulting From Ingestion Of Uranium In Ground Water Monument Valley, Arizona, Site

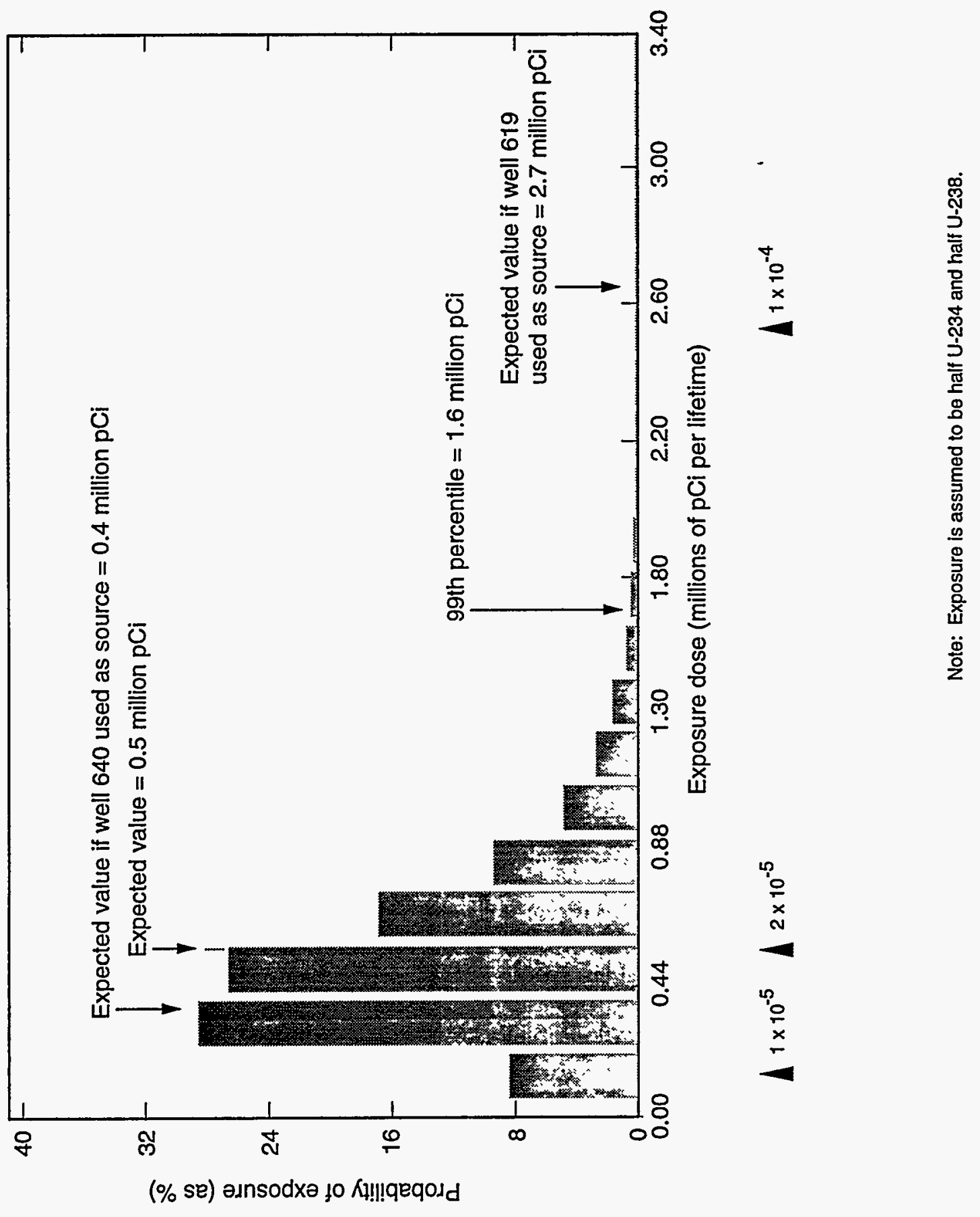


cancer risk of $1 \times 10^{-4}$ (one increased chance of developing cancer in a population of 10,000$)$. The expected exposure value $(549,000 \mathrm{pCi}$ per lifetime) results in an excess lifetime cancer risk of $2 \times 10^{-5}$ (two increased chances of developing cancer in a population of 100,000 ). The distribution presented here is considered conservative because it is based on cumulative 70-year exposure durations. As discussed previously, this exposure duration is probably appropriate, but ground water uranium concentrations resulting from former processing activities at this site are expected to decline now that the tailings have been removed. Therefore, this distribution would overestimate risk. For monitor well 619, the increase in lifetime cancer risk is $1 \times 10^{-4}$ lone increased chance of developing cancer in a population of 10,000$)$. This value falls at the upper-bound NCP value of $1 \times 10^{-4}$.

Uranium is the only radionuclide statistically above background in the plume. No uranium progeny are present at concentrations statistically above background levels. Therefore, no evaluation of uranium decay products was performed.

\subsection{PRIVATE WELL 640}

As discussed in Sections 3.2 and 3.3, data show elevated concentrations of sulfate and uranium in private well 640 . Because only limited data are available from well 640, distributions of expected intake were not derived. Therefore, expected intake values for sulfate and uranium ingestion from well 640 have been calculated using the appropriate simulation distribution means for daily water ingestion rate and body weight and the constituent concentration observed in the December 1993 sample. These values indicated on the simulated distribution (Figures 6.2, 6.6, and 6.7).

Slight to no noncarcinogenic adverse health effects are expected. Infants could possibly experience some diarrhea from sulfate exposure. Noncarcinogenic health effects from uranium exposure would not be expected.

The increase in lifetime cancer risk for well 640 would be less than $2 \times 10^{-5}$. This value falls below the NCP guidance value.

\subsection{LIMITATIONS OF RISK EVALUATION}

The following potential limitations apply to interpretations of this risk evaluation:

- The risk assessment evaluates only risks related to inorganic ground water contamination. Potential contamination with any of the few organic constituents used in uranium processing has not been addressed.

- Subpopulations that might have increased sensitivity are not specifically addressed on the graphs. 
- Some individuals may be more sensitive to the toxic effects of certain constituents for undetermined reasons.

- Data available to interpret potential adverse health effects are not always sufficient to allow accurate determination of all health effects (i.e., lack of testing in humans or testing of dose ranges other than those expected at this site).

- Although plume movement is evaluated hydrologically and geochemically, the monitoring locations sampled may not be the most contaminated portion of the plume.

The evaluation presented here has considered these limitations and compensated wherever possible by presenting toxicity ranges rather than point estimates to incorporate as much variability as could be reasonably defined. Section $\mathbf{8 . 2}$ discusses the impact of these potential limitations more fully. 
. 


\subsection{LIVESTOCK AND ENVIRONMENTAL EVALUATION}

The objective of this section is to assess the potential for site-related contaminated ground water to adversely affect existing biological communities, livestock, and other agricultural practices in the vicinity of the Monument Valley site. The EPA has developed a qualitative approach to be used in ecological risk evaluations (EPA, 1989). As part of this qualitative approach, the EPA recommends conducting ecological assessments in a phased approach because it ensures the most effective use of resources while ensuring performance of all necessary work (EPA, 1992c). This approach consists of four phases: the identification of potentially exposed habitats (phase 1), the collection of chemistry data (phase 2), the collection of biological samples (phase 3), and the performance of toxicity testing (phase 4). If the initial inspection of the habitats and the analysis of media samples indicate that there is no, or very low, potential for an ecological risk, the assessment will likely be complete. If the early phases of the assessment indicate that the constituents may be adversely affecting ecological receptors, a higher level of analysis may be warranted. The ecological risk assessment at the Monument Valley site consists of the first two phases of EPA's approach. This approach provides a screening level assessment of the risks associated with potential exposure to contaminated media at the site.

Based on the current knowledge of the Monument Valley site, the only contaminated medium associated with the site is ground water. Hydrogeological (Section 2.3.3) and geochemical (Section 3.5) evaluation of site conditions has determined that contaminated ground water is not discharging to Cane Valley Wash, and no other surface expression of contaminated ground water has been identified.

\subsection{EXPOSURE PATHWAYS AND RECEPTORS}

For an exposure to occur, there must be a source of contamination with a mechanism of transport to a receptor. As discussed in Sections 2.3 .3 and 3.5, it is unlikely that contaminated ground water is discharging to the surface. Therefore, no complete exposure pathways have been identified. In order for an exposure pathway to be completed at this site, contaminated ground water would need to be accessed.

A potential exposure pathway is via plant root uptake of contaminated ground water. The depth to ground water immediately downgradient of the site ranges from approximately $27 \mathrm{ft}(8 \mathrm{~m})$ to $48 \mathrm{ft}(15 \mathrm{~m})$, and deep rooted plants could access the contaminated ground water. This potential exposure pathway will be evaluated.

A future exposure pathway could occur if contaminated ground water were used to provide water for livestock or for irrigation. Therefore, this risk assessment also evaluates this potential exposure pathway.

\subsection{SITE VICINITY PLANT WILDLIFE CHARACTERIZATION}

A description of the plant communities at or in the vicinity of the Monument Valley site is based on information compiled in previous reports (EES, 1986; DOE, 1989). No recent ecological field surveys have been conducted. 
The upland plant community at the Monument Valley site is desert shrub. The dominant plant species observed in the desert shrub habitat north of the former tailings piles were black greasewood, shadscale, broom snakeweed, and soapweed. These species, plus black brush, cliffrose, widely scattered juniper, and singleleaf ash, occupy the rocky terrain south and west of the site. Rabbitbrush, vanclevea, and Russian thistle dominate the blow sand areas just west of the former tailings pile (EES, 1986).

Wetland and riparian plant communities occur at the frog ponds and along Cane Valley Wash. As indicated in Section 2.3.3, the contaminant plume has not extended to Cane Valley Wash and is not expected to in the future.

A total of 19 species of amphibians and reptiles may occur in the site area. Observed species include the side-blotched, western whiptail, leopard, desert spiny, and sagebrush lizards. An estimated 42 species of nesting birds may occur near the site. Seventeen species were observed near the site, the black-throated sparrow and rock wren being the most common. Numerous ducks were observed in the frog ponds' vicinity. Twenty-six species of mammals may reside near the Monument Valley site; the black-tailed jackrabbit, desert cottontail, and white-tailed antelope squirrel were observed (Burt, 1985; DOE, 1989) Big game species are not known to occur at or near the site.

A list of threatened and endangered species and other species of concern that may occur in the tailings site area was developed through consultation with the Fish and Wildlife Service (FWS) and the Navajo Nation (Baucom, 1985; Diswood, 1985; House, 1985; Ruesink, 1985). The consultation process resulted in the identification of 13 species ( 9 species of wildlife and 4 species of plant life). It was determined that no threatened and endangered wildlife species would likely occur near the site. However, the threatened and endangered species consultation process will be updated before a ground water compliance strategy is implemented at the Monument Valley site.

Suitable habitat for three of the four plant species (Cutler milkweed, Monument Valley milkvetch, and Eremocrinum alvomarginatium) of concern occur in the site area. However, these species were not observed at or near the Monument Valley site in 1986 (EES, 1986).

\subsection{CONSTITUENTS OF POTENTIAL CONCERN}

Because ecological effects differ from human health effects, the complete list of constituents above background (Section 3.3) plus TDS are considered constituents of potential concern when evaluating ecological and livestock impacts (Table 7.1). 


\section{$7.4 \quad$ POTENTIAL IMPACT ON PLANTS}

\subsubsection{Native Plants}

The primary factor to consider regarding the potential for the Monument Valley ground water plume to exert a negative effect on plants is the toxicity of the constituents of potential concern. These constituents were compared with screening level benchmarks for terrestrial plants. Of the 14 site constituents, benchmarks for terrestrial plants are available for 4 (Table 7.1). The concentrations of constituents in the Monument Valley plume were much lower then the terrestrial vegetation screening benchmarks for iron, manganese, uranium, and vanadium. This indicates that even if the desert plants growing in the land over the plume could send roots down 27 to $48 \mathrm{ft}$ ( 8 to $15 \mathrm{~m}$ ), there would be no adverse effects from these constituents.

Given that these are 10 constituents of potential concern that do not have terrestrial plant screening guidelines and that some, like sulfate, are highly elevated in plume ground water, an analysis of the rooting depth of the plants growing over the plume was performed. Site-specific data regarding the rooting depth of plants were not collected, and it is recognized that rooting depth is species-specific and may be highly variable.

As indicated in Section 7.2, black greasewood, shadscale, broom snakeweed, and soapweed are common plants growing on land over the plume. Other potentially deep rooted shrubs such as four-winged saltbush and rabbitbrush also occur in this area. There were no trees such as juniper or singleleaf ash in this area.

Benson, et al., (1976) reported that a black greasewood plant community in a desert shrub ecosystem was obtaining a continuous supply of water by tapping into ground water at a depth of $12 \mathrm{ft}(4 \mathrm{~m})$. Observations on the UMTRA Project during ground water investigations at the Grand Junction site disposal cell (Cheney disposal cell) indicated that 25- to $30-\mathrm{ft}$ (8- to 9-m)-long roots were tapping into ground water. Black greasewood was the common shrub in the area, and it was assumed this species had sent roots to the ground water. Data for the other common species indicate that shadscale could root to a depth of about $3 \mathrm{ft}(0.9 \mathrm{~m})$, broom snakeweed to $8 \mathrm{ft}(2.4 \mathrm{~m})$, and yucca to $7 \mathrm{ft}(2.1 \mathrm{~m})$ (Benson et al., 1976; Foxx et al., 1984). Maximum rooting depth reported for rabbitbrush is $15 \mathrm{ft}(4.6 \mathrm{~m})$ and for four-winged saltbush is $25 \mathrm{ft}(8 \mathrm{~m})$ (Foxx et al., 1984). In addition, four-winged saltbush roots over $20 \mathrm{ft}(9 \mathrm{~m})$ long were observed in deep washes in southern New Mexico (Burt, 1985).

Based on this evidence, it appears that most of the shrubs growing on land over the plume do not root deep enough to access the contaminant plume. However, black greasewood and four-winged saltbush do have the potential to reach the ground water. Black greasewood and four-winged saltbush are salt-tolerant species, and the high concentrations of sulfate and TDS in the contaminated ground water may not be detrimental to these species. 


\subsubsection{Produce}

A future hypothetical use of contaminated ground water downgradient of the site is the irrigation of garden produce. In Table 7.1, constituent concentrations in ground water are compared with irrigation water guidelines designed to protect plants (EPA, 1972).

Four constituents of potential concern (iron, manganese, TDS, and vanadium) have comparison criteria; the 95 percent UCL for the average ground water concentrations of iron, manganese, and vanadium in the contaminant plume are below the guidelines. TDS concentrations fall within the range that could result in toxic effects to agricultural plants. It is likely that only the most tolerant plants grown on permeable soil would survive continuous exposure to the TDS present in plume ground water (EPA, 1972).

Other basic criteria required to evaluate the suitability of water quality for irrigation are the total soluble salt content and the sodium hazard. Excess salt in water increases the osmotic pressure of the soil solution. This increase can cause a physiological drought condition in the plants. The total soluble salt content of water can be measured by the specific conductance (electrical conductivity). The 95 percent UCL for the mean specific conductance of ground water in the plume is 5000 micromhos per centimeter $(\mu \mathrm{mhos} / \mathrm{cm})$. This value is well above the upper end of the acceptable range for agricultural crops at $3000 \mu \mathrm{mhos} / \mathrm{cm}$ (Follett and Soltanpour, 1985).

Sodium concentrations can contribute to the total salinity of an irrigation water and may be directly toxic to sensitive crops. However, the primary concern with elevated sodium concentrations is the adverse effect on the physical characteristics of soils. For example, an increase in colloidally absorbed sodium resulting in hard compact soil could occur. However, clayey soils are required to achieve this effect. The sodium hazard of water is expressed as the sodium adsorption ratio (SAR), which is calculated as the proportion of sodium to calcium plus magnesium in the water. Water with a SAR value greater than 10 should not be used as the sole source of irrigation water for long periods of time (Follett and Soltanpour, 1985). Using the 95 percent UCL for the mean ground water concentrations of sodium, calcium, and magnesium, a SAR of 1.2 is calculated. Because of the low SAR value and the finegrained alluvial sands (not very much clayey soil exists in this area), effects from high sodium irrigation water would not be expected to harden the soil.

\subsection{POTENTIAL IMPACTS TO AQUATIC AND TERRESTRIAL WILDLIFE}

To elevate the future hypothetical impact on aquatic organisms and terrestrial wildlife of using contaminated ground water in a livestock pond (i.e., to animals drinking from the pond or aquatic life living in the pond), the constituents of potential concern were compared to aquatic life water quality criteria and terrestrial wildlife screening benchmarks (Table 7.1). The 95 percent UCL for the mean concentration of nitrate $(1300 \mathrm{mg} / \mathrm{L})$ exceeds the aquatic life criterion $(90 \mathrm{mg} / \mathrm{L})$ more than an order of magnitude. If contaminated ground water were used to create a pond, the high level of nitrate would have toxic effects on aquatic organisms that may become 
established. The criteria for chloride, iron, and manganese were not exceeded (Table 7.1). No aquatic life water quality values are available for the remaining constituents.

Comparison of the 95 percent UCL concentration with screening benchmarks for terrestrial wildlife resulted in none of the benchmarks being exceeded (Table 7.1). Benchmarks are not available for many of the site constituents. So their effect, if any, on terrestrial wildlife cannot be evaluated.

7.6 POTENTIAL IMPACTS ON LIVESTOCK

In order to evaluate what the potential impact to livestock could be from drinking contaminated ground water, the 95 percent UCL for the mean ground water concentrations of nitrate, sulfate, TDS, and vanadium are compared to drinking water concentrations considered protective of livestock (EPA, 1972) Table 7.1. No comparison water quality criteria have been reported for the other constituents of potential concern.

The 95 percent UCL for the mean ground water concentrations of nitrate and sulfate exceed the water quality guidelines while the UCL concentrations for TDS $(4300 \mathrm{mg} / \mathrm{L})$ and vanadium $(0.02 \mathrm{mg} / \mathrm{L})$ are below the comparison guidelines (10,000 $\mathrm{mg} / \mathrm{L}$ and $0.1 \mathrm{mg} / \mathrm{L}$, respectively). Furthermore, the National Academy of Science has established a guideline for TDS in drinking water for livestock (7000 $\mathrm{mg} / \mathrm{L}$ ) because of potential toxic effects in young cattle or cattle that are pregnant or lactating (EPA, 1972). The 95 percent UCL for the mean TDS level in ground water does not exceed this level.

The ground water concentration of nitrate $(1200 \mathrm{mg} / \mathrm{L})$ is more than one order of magnitude above the comparison guidelines $(100 \mathrm{mg} / \mathrm{L})$. If this ground water were the sole source of drinking water for livestock, it would result in the development of methemoglobinemia in ruminants (e.g., cattle) (Deeb and Sloan, 1975; NAS, 1972). The 95 percent UCL for the mean sulfate concentration $(2900 \mathrm{mg} / \mathrm{L})$ also exceeds the livestock water quality criterion $(1000 \mathrm{mg} / \mathrm{L})$. This level of sulfate could cause severe diarrhea in exposed animals (Church, 1984). Although the levels in the literature are somewhat conflicting, adverse effects (including weight loss, sulfhemoglobinemia, coordination loss, convulsions, and death) were reported in cattle chronically exposed to sulfate in drinking water at levels as low as $2200 \mathrm{mg} / \mathrm{L}$ (EPA, 1972; NAS, 1974).

Evaluation of site-specific ground water concentrations in comparison with guidelines protective of livestock indicate that in the alluvial ground water plume, nitrate and sulfate concentrations could cause severe adverse health effects to livestock.

\subsection{LIMITATIONS OF THE ECOLOGICAL RISK ASSESSMENT}

The qualitative evaluation of potential ecological risks presented here is a screening level assessment of the risks to plants, wildlife, and livestock associated with the potential exposure to the contaminated ground water at the Monument Valley site. Sources of uncertainty in any ecological assessment arise from the monitoring data, exposure assessments, toxicological information, and the inherent complexity within 
the ecosystem. In addition, methods of predicting nonchemical stresses (e.g., drought), biotic interactions, behavior patterns, biological variability (e.g., differences in physical conditions, nutrient availability), and resiliency and recovery capacities are often unavailable. Also, only limited ecotoxicological reference data for terrestrial plants, terrestrial wildlife, and livestock are available. Therefore, most ecological constituents of potential concern could not be evaluated in this report. In addition, considerable uncertainty is associated with the toxicity of mixtures of constituents because there has been little scientific research in this area. The combination of these factors could have resulted in an underestimation of potential risks.

\subsection{SUMMARY}

Based on the current knowledge of the Monument Valley site, the only contaminated medium associated with former processing activities at the site is ground water. Hydrogeological and geochemical evaluation of site conditions has determined that . contaminated ground water is not discharging to Cane Valley Wash. No other surface expressions of contaminated ground water been identified. Therefore, surface water and sediment have not been evaluated for potential adverse ecological or livestock affects. This section assessed the potential for site-related ground water constituents to adversely affect existing biological communities and agricultural practices in the vicinity of the site.

Potential exposure pathways assessed were plant uptake of contaminated ground water and the hypothetical future construction of a stock pond using contaminated ground water. Since the depth to ground water is less than $30 \mathrm{ft}$ [ $9 \mathrm{~m}]$ in some areas north of the site, some deep rooted plants, such as black greasewood, could access the contaminated ground water. However, most plants growing on land over the plume would likely not be able to send roots deep enough to access this ground water. Comparison of the contaminated ground water with screening benchmarks for terrestrial plants showed there were no constituents that exceeded the benchmarks. This indicates that for the few plants that may access the plume, few, if any, toxic effects are expected.

The use of contaminated ground water to irrigate garden produce was also evaluated. The only constituents of potential concern that have guidelines protective of plants are iron, manganese, sulfate, TDS, and vanadium. Of these constituents, only TDS has the potential to cause adverse effects to plants if the contaminated ground water were used as a continuous source of irrigation water.

Other criteria evaluated in terms of the suitability of water quality for irrigation were total soluble salt content and the sodium hazard. Evaluation of the salt content in the plume indicates that chronic use of the ground water to irrigate crops could cause a physiological drought condition in the plants. The sodium absorption ratio was below the level that could result in damage to soil profile.

Aquatic life would likely be adversely affected by the high nitrate levels in the contaminated ground water if this ground water were used to create a stock pond. Watering livestock from such a pond would also be unacceptable due to elevated nitrate and sulfate concentrations. Nitrate exposure would result in the development 
of methemoglobinemia in ruminants (e.g., cattle). Sulfate exposure would cause severe diarrhea and other adverse health effects in animals. 


\subsection{INTERPRETATION AND RECOMMENDATIONS}

This baseline risk assessment was conducted for the Monument Valley site to assess if the presence of site-related radiological and nonradiological hazards in ground water could adversely affect human health or the environment.

\subsection{RISK SUMMARY}

Currently, contaminated ground water is not used by the Navajo people for domestic (drinking, bathing, and cooking) or agricultural (watering gardens and livestock) purposes. Therefore, human health is not currently at risk because of the use of the ground water for these purposes.

It should be noted, however, that several plant species present in the vicinity of the site are used by the Navajo people as a cultural resource. An exposure pathway could be completed if the roots of any of these plants access the contaminated ground water and bioaccumulate site-related constituents at levels that could be harmful if ingested or inhaled by people. Based on current knowledge of the site, black greasewood and four-winged saltbush have the greatest potential to access the ground water via their root system. Because no site-specific plant uptake data are available and because of limited plant uptake data in the literature, the potential risks due to the ingestion or inhalation routes are not evaluated in this risk assessment.

A hypothetical future use scenario of people using alluvial ground water from the most contaminated portion of the plume as a drinking water source was assessed for possible adverse health effects. The evaluation concluded that certain adverse human health effects could be expected. Additionally, potential effects to ecological and agricultural resources were evaluated.

\subsubsection{Human health}

The constituents of potential concern identified for the Monument Valley site are manganese, nitrate, strontium, sulfate, uranium, and vanadium. Uranium is the only carcinogen in this group of constituents. The primary noncarcinogenic adverse health effects would result from the ingestion of nitrate and sulfate, especially by infants. Following short-term exposure to nitrate, the majority of infants would experience severe toxicity; i.e., methemoglobinemia. Sulfate levels could cause severe diarrhea. Gastrointestinal distress, such as the effects that are possible from sulfate exposure, may enhance the toxicity of nitrate in infants. Chronic exposure of children to manganese could produce neurological symptoms similar to those seen in early manifestations of Parkinson's disease.

Adverse noncarcinogenic health effects would not be expected from exposures to the remaining constituents of potential concern at the site (strontium, uranium, and vanadium).

The carcinogenic risk calculated for uranium is $2 \times 10^{-5}$ ( 2 increased chances in a population of 100,000 of developing cancer), a value which falls below the NCP 
upper-bound value of $1 \times 10^{-4}$ ( 1 chance of developing cancer in a population of 10,000).

If the additional exposure dose from dermal contact with contaminated alluvial ground water is added to the drinking water exposure dose, this added dose would not alter the present results. Additionally, exposure from the dermal contact route would not be likely to produce toxicity if the drinking water pathway were eliminated.

\section{Private well 640}

Slight to no noncarcinogenic adverse health effects are expected from exposure to the sulfate or uranium levels in ground water accessed by private well 640. Infants could possibly experience some diarrhea from sulfate exposure. The increase in lifetime cancer risk is $2 \times 10^{-5}$ ( 2 increased chances of developing cancer in a population of 100,000$)$. This value falls below the NCP value of $1 \times 10^{-4}$.

\subsubsection{Environmental and agricultural}

All constituents identified in this document as being present in the alluvial ground water plume in levels above background were considered constituents of potential concern when evaluating potential environmental and agricultural impacts. These constituents include ammonium, calcium, chloride, iron, magnesium, manganese, nitrate, potassium, sodium, strontium, sulfate, uranium, and vanadium. The amount of TDS present in the ground water plume was also considered in this assessment.

Potential current exposure of terrestrial plants to contaminated ground water was evaluated. The depth to ground water is less than $30 \mathrm{ft}(9 \mathrm{~m})$ in some areas north of the site; and deep rooted plants, such as black greasewood and four-wing saltbush, could potentially access the contaminated ground water. Comparison of ground water concentrations of iron, manganese, uranium, and vanadium against published screening benchmarks for terrestrial plants shows that none of these constituents exceed their respective benchmarks. This indicates that toxic effects would not be expected from exposure of deep rooted plants to these four constituents. Screening benchmarks for terrestrial plants are not available for the remaining constituents of potential concern at the site. However, both black greasewood and four-wing saltbush are known to be salt-tolerant. Thus, exposure to the high concentrations of sulfate and TDS in the contaminated ground water plume may not be detrimental to these species.

Hypothetical future scenarios of using the contaminated ground water to irrigate plants, water livestock or wildlife, or provide a habitat for aquatic life, were assessed.

The constituents of potential concern that have irrigation guidelines protective of plants are iron, manganese, TDS, and vanadium. Iron, manganese, and vanadium levels in ground water are below irrigation guideline levels. However, TDS concentrations in plume ground water fall within a range that could be toxic to nontolerant agricultural plants. Furthermore, because of the salt content in the plume, chronic use of the ground water for crop irrigation could elicit a physiological drought condition in the plants. 
Potential future risks associated with creation of a livestock pond fed by contaminated alluvial ground water were evaluated. The aquatic life associated with the presence of such a pond would be adversely affected by high nitrate levels. Watering livestock from such a pond would not be acceptable due to elevated nitrate and sulfate concentrations. Nitrate exposure would result in the development of methemoglobinemia in ruminants (e.g., cattle). Sulfate exposure would cause severe diarrhea and other adverse health effects to livestock. Comparison of the constituents of potential concern that have screening benchmarks for terrestrial wildife (manganese, strontium, uranium, and vanadium) indicates that terrestrial wildlife would not be expected to experience any adverse effects from these four constituents if contaminated pond water was ingested. However, benchmarks for terrestrial wildlife are not available for the remaining constituents of potential concern at the site.

\subsection{LIMITATIONS OF THIS RISK ASSESSMENT}

Limitations of this baseline risk assessment include the following:

- The potential risks to the Navajo people due to the ingestion or inhalation of plants used as cultural resources or crops are not evaluated in this risk assessment, because there are no site-specific plant uptake or bioconcentration data and limited plant uptake data can be found in the literature.

- This document evaluates risks associated with exposures only to inorganic constituents of ground water at the UMTRA site near Monument Valley. Those few organic constituents related to uranium processing have not been considered.

- The toxicity of any constituents varies from person to person. For example, normal variability in biochemical factors among individuals, differences in medical history, previous exposures to toxicants, and dietary and exercise habits can all affect susceptibility to chemical toxicity. This assessment attempts to incorporate that variability by presenting probability distributions for potential exposures and ranges of exposures associated with toxic effects. However, it is not possible to account for all sources of variability and still present useful and meaningful analyses. Cases in which specific subpopulations are known to be more sensitive to toxic effects of given constituents have been noted.

- Standardized reference values developed by agencies such as the EPA are used to determine toxic responses in humans. These reference values, themselves, have limitations including the following:

- Not all constituents elevated above background at the site have toxicity or bioconcentration data available.

- In some cases, data obtained from laboratory animal testing at exposure doses different from those expected at the site were used to determine toxicity. The relationship between dose and response is not always linear, and humans do not always exhibit the same responses as animals. 
- Data used to determine toxicity are generally based on exposure to only one constituent of concern. In reality, potential exposures will generally occur simultaneously to several site-related constituents. The interactive effects of multiple constituents and the impact of these interactions on expected toxicity generally cannot be accurately assessed from existing data.

- Although considerable effort has been directed at determining plume movement and placing monitor wells in locations that capture maximal contamination, variability in physical systems and models used to determine constituent plume migration could still result in well placements that do not measure the highest constituent concentrations or determine the fullest extent of plume impact.

- The results presented here are based on ground water samples filtered with an 0.45-micrometer filter. The effect of filtration differs for different elements. Filtered samples generally have lower or equal concentrations of a given constituent than unfiltered. Constituents in suspension could be lost with filtration, yet still produce toxic effects if ingested and broken down in the acidic environment of the stomach. Cases where filtration may have had an impact on ground water sample concentrations for a given constituent were considered in interpreting the results.

- Variability can be introduced through sampling and analytical processes. However, the data at UMTRA Project sites have been collected over many years and subjected to rigorous quality assurance procedures. The use of multiple samples introduces high confidence in the reliability and validity of the collected data.

- The drinking water pathway is considered the major determinant of exposure in this assessment. Although the dermal contact pathway has been screened and determined not to contribute significantly to the total exposure, some of the factors in these screening calculations have considerable uncertainties; e.g., dermal permeability coefficients.

Based on available data, this assessment presents the magnitude and extent of contamination and the potential risks expected from exposure to the contaminated ground water as accurately as possible and conveys areas of uncertainty. By presenting ranges of toxic effects, summaries of available data on health effects and interactions, and outlines of potential limitations, this document provides a reasonable interpretation of potential health risks associated with ground water contamination at this site.

\subsection{GROUND WATER STANDARDS}

The EPA has established health and environmental protection standards for the UMTRA Project (40 CFR 192). The UMTRA Project MCLs for ground water protection are summarized in Table 8.1. One or more exceedences of the MCLs for cadmium, nitrate, selenium, combined radium-226 plus -228 , and uranium occurred in ground water samples collected at the site between 1988 and 1994. In addition to 
Table 8.1 Maximum concentration limits and health advisories of constituents

\begin{tabular}{|c|c|c|c|}
\hline Constituent & $\begin{array}{c}\text { UMTRA MCL } \\
\text { (mg/L) }\end{array}$ & $\begin{array}{l}\text { Health advisories } \\
\text { 10-kg child, 10-day } \\
\text { (mg/L) }\end{array}$ & $\begin{array}{l}\text { Health advisories } \\
\text { 70-kg adult lifetime } \\
\text { (mg/L) }\end{array}$ \\
\hline \multicolumn{4}{|l|}{ Chemicals (inorganic) } \\
\hline Antimony & - & 0.01 & $0.003^{a}$ \\
\hline Arsenic & 0.05 & - & - \\
\hline Barium & 1.0 & - & 2 \\
\hline Boron & - & 0.9 & 0.6 \\
\hline Cadmium & $0.01^{a}$ & $0.04^{a}$ & $0.005^{a}$ \\
\hline Chromium & 0.05 & 1 & 0.1 \\
\hline Lead & 0.05 & - & - \\
\hline Manganese & - & - & - \\
\hline Mercury & 0.002 & - & 0.002 \\
\hline Molybdenum & 0.1 & $0.04^{a}$ & $0.04^{\mathrm{a}}$ \\
\hline Nickel & - & 1 & 0.1 \\
\hline Nitrate & $44^{a, b, c}$ & $44^{a, b, c, d}$ & - \\
\hline Selenium & $0.01^{a}$ & - & - \\
\hline Silver & 0.05 & 0.2 & 0.1 \\
\hline Strontium & - & 25 & 17 \\
\hline Sulfate & - & - & - \\
\hline Thallium & - & $0.007^{\mathrm{a}}$ & $0.0004^{a}$ \\
\hline Vanadium & - & - & - \\
\hline Zinc & - & 6 & 2 \\
\hline \multicolumn{4}{|l|}{ Radionuclides } \\
\hline Radium-226/-228 & $5 \mathrm{pCi} / L^{a, b}$ & - & - \\
\hline $\begin{array}{l}\text { Uranium } \\
\text { (U-234/-238) }\end{array}$ & $\begin{array}{c}30 \mathrm{pCi} / \mathrm{L}^{e} \\
(0.044 \mathrm{mg} / \mathrm{L})\end{array}$ & - & - \\
\hline
\end{tabular}

${ }^{\mathrm{a} E x c e e d e d ~ i n ~ o n e ~ o r ~ m o r e ~ s a m p l e s ~ f r o m ~ a l l u v i a l ~ p l u m e ~ w e l l s ~} 606$ or 655 between April 1988 and December 1994.

${ }^{b}$ Exceeded in one or more samples from alluvial background wells $602,603,616$, or 617 between April 1988 and December 1994.

${ }^{\mathrm{C}}$ Equal to $10 \mathrm{mg} / \mathrm{L}$ nitrate as nitrogen.

¿Under review.

${ }^{e}$ Exceeded in one or more samples from the De Chelly Sandstone aquifer well 657 between April 1988 and December 1994. 
standards specific to the UMTRA Project, the EPA has published drinking water health advisory levels for both long- and short-term exposures. These advisory levels, along with exceedences measured in ground water at the site, are also presented in Table 8.1.

\subsection{RISK MITIGATION MEASURES}

This section presents possible ways to restrict access to ground water in order to mitigate risks if the ground water were to be used in the future.

Institutional controls are defined in the ground water standards for UMTRA as mechanisms that can be effectively used to protect human health and the environment by controlling access to contaminated ground water. Although the proposed standards refer to institutional controls for long periods of time (e.g., up to 100 years during natural flushing), this concept can also be applied to short-term restrictions of access to ground water. Because not all 24 UMTRA sites can be evaluated simultaneously, institutional controls are needed before remedial action decisions are made for individual sites.

Institutional controls cannot exclusively depend on markers, fences, or health advisories, as they can too easily be ignored. An education campaign at both the local level and the tribal agency level could curb, but would not stop, usage. If access were denied, especially to water sources traditionally used in the past, it would be necessary to provide a readily accessible alternative water supply. An alternative supply would need to be installed with the consultation of the local authorities.

Government entities can implement successful institutional controls. The Division of Natural Resources manages water resources within the Navajo Nation. Both the Division of Natural Resources of the Navajo Nation and the Navajo Nation Environmental Protection Agency are responsible for water supply, standards, and discharge. The Division of Natural Resources is responsible for administering the water permit system and for developing water code compliance regulations for the Navajo Nation.

Currently, two permit categories exist for water access: permits for well drilling and permits for water use. Both permits are needed to drill new wells. Permits usually undergo an administrative and a technical review. Agency implementation of institutional controls would be most effective at the technical review level. Tribal agencies and local authorities would have to agree to the technical criteria for implementing institutional control of ground water use.

After obtaining signature approval from the Director of Water Resource Management, a permit is sent to the Navajo Department of Justice to determine any jurisdictional issues or problems with water rights. The Executive Director of the Division of Natural Resources then reviews the permit to determine the potential for regional, political, or social concerns or impacts.

Establishing institutional controls and ensuring the protection of human health and the environment would require a consensus among Navajo Nation governmental 
agencies and local Navajo governing authorities and chapter houses. Local authorities should probably be responsible for monitoring new wells to ensure that they have been approved. The governing authorities would also need to be informed of monitoring results and the anticipated duration of contamination problems. Chapter houses maybe the most effective organizations for educating local residents about potential risks and the necessity of access restrictions.

\section{RECOMMENDATIONS}

At the Monument Valley site, no permanent physical barrier prevents access to contaminated ground water at the site. Assessment of a future use scenario of drinking contaminated ground water by people indicates that adverse health effects could occur. Therefore, the contaminated alluvial ground water should not be used as a drinking water source. Furthermore, use of contaminated alluvial ground water for livestock ponds is not recommended. 


$$
\cdot \cdot \cdot
$$




\subsection{LIST OF CONTRIBUTORS}

The following individuals contributed to the preparation of this document.

\begin{tabular}{ll}
\hline Name & Contribution \\
\hline J. Marshall, K. Wilk & Document coordinator \\
J. Lewis, J. Marshall & Risk assessment; toxicology \\
T. Jackson & Geochemistry \\
A. Miller, J. Richey & Hydrology; hydrogeology \\
K. Wilk & Statistical evaluation \\
C. H. Day, C. Burt & Ecological assessment \\
R. Neri-Zagal & Institutional control \\
K. DeGruyter & Graphic design \\
J. Jones & Technical editing and document production \\
\hline
\end{tabular}





\subsection{REFERENCES}

Aiyar, A. S., and A. Sreenivasan, 1961. Proc. Soc. Exp. Biol. Med., Vol. 107, pp. 914-916.

Ballou et al. (J. E. Ballou, R. A. Gies, A. C. Case, D. L. Haggar, R. L. Buschbom, and J. L. Ryan), 1986. "Deposition and Early Disposition of Inhaled Uranium-233 Uranyl Nitrate and Uranium-232 Uranyl Nitrate in the Rat," in Health Physics, Vol. 51, pp. 755-772.

Baucom, F., 1985. U.S. Fish and Wildlife Service, Ecological Services, Phoenix, Arizona, personal communication to David Lechel, Environmental Services, Jacobs Engineering Group Inc., Albuquerque, New Mexico, 19 August 1985.

Belehova, B. A., 1969. Scientific Transactions of the Irkutsk State Medical Institute, Vol. 96, pp. 20-23 (in Russian).

Benson et al. (F. A. Benson, R. F. Miller, and I. S. McQueen), 1976. "Moisture Relationships in Twelve Northern Desert Shrub Communities Near Grand Junction, Colorado," Ecology, Vol. 57, No. 6, pp. 1104-1124.

Berlin, M., and B. Rudell, 1986. "Uranium," in Handbook on the Toxicology of Metals, Volume II, second edition, L. Friberg, G. F. Nordberg, and V. B. Vouk, eds., Elsevier Science Publishers, New York, New York, pp. 647-658.

Bolyai et al. (J. Z. Bolyai, R. P. Smith, and C. T. Gray), 1972. "Ascorbic Acid and Chemically Induced Methemoglobinemias," in Toxicological Applied Pharmacology, Vol. 21, pp. 176-185.

Burt, C. J., 1985. "Unpublished Field Investigation, Mexican Hat, Utah, and Monument Valley, Arizona, Uranium Mill Tailings Sites," UPDCC File Location Nos. 9.15.0 and 19.15.0, prepared by the Technical Assistance Contractor, Albuquerque, New Mexico, for the U.S. Department of Energy, UMTRA Project Office, Albuquerque Operations Office, Albuquerque, New Mexico.

Byerrum et al. (R. U. Byerrum, R. E. Eckardt, L. L. Hopkins), 1974. Vanadium, National Academy of Sciences, Washington, D.C.

Byrne, A. R., and L. Kosta, 1978. Sci. Total Environ., Vol. 10, pp. 17-30.

Church, D. C., 1984. Livestock Feeds and Feeding, second edition, McGraw-Hill Publishing Co., New York, New York.

Comar, C. L., and R. H. Wasserman, 1964. "Strontium," in Mineral Metabolism, C. L. Comar and F. Bronner, eds., Volume II, Part A, Academic Press, New York and London, pp. 523-572. 
Cooley et al. (M. E. Cooley, J. W. Harshbarger, J. P. Akers, and W. F. Hardt), 1969. Regional Hydrogeology of the Navajo and Hopi Indian Reservations, Arizona, New Mexico, and Utah, U.S. Geological Survey Professional Paper 521-A, Washington, D.C.

Cothern, C. R., and W. L. Lappenbusch, 1983. "Occurrence of Uranium in Drinking Water in the United States," in Health Physics, No. 45, pp. 89-99.

Curran et al. (G. L. Curran, D. L. Azarnoff, and R. E. Bolinger), 1959. Journal of Clinical Investigation, Vol. 38, pp. 1251-1261.

Curzon, M. E. J., 1985. "The Relation Between Caries Prevalence and Strontium Concentrations in Drinking Water, Plaque, and Surface Enamel," in Journal of Dental Research, Vol. 64(12), pp. 1386-1388.

DOE (U.S. Department of Energy), 1996a. Programmatic Environmental Impact Statement for Ground Water Contamination at the UMTRA Sites, U.S. Department of Energy, Grand Junction Projects Office, Grand Junction, Colorado.

DOE (U.S. Department of Energy), 1996b. "Supplement to the Baseline Risk Assessment of Ground Water Contamination at the Monument Valley Uranium Mill Tailings Site, Cane Valley, Arizona," U.S. Department of Energy, Grand Junction Projects Office, Grand Junction, Colorado.

DOE (U.S. Department of Energy), 1995. Site Observational Work Plan for the UMTRA Project Site at Grand Junction, Colorado, DOE/AL/62350-215, Rev. 0, prepared for the U.S. Department of Energy, Grand Junction Projects Office, Grand Junction, Colorado.

DOE (U.S. Department of Energy), 1993. Remedial Action Plan for the Codisposal and Stabilization of the Monument Valley and Mexican Hat Uranium Mill Tailings at Mexican Hat, Utah, final, UMTRA-DOE/AL 050509.0000, UMTRA Project Office, Albuquerque Operations Office, Albuquerque, New Mexico.

DOE (U.S. Department of Energy), 1989. Environmental Assessment of Remedial Action at the Monument Valley Uranium Mill Tailings Site, Monument Valley, Arizona, final, DOE/EA-0368, UMTRA Project Office, Albuquerque Operations Office, Albuquerque, New Mexico, June 1989.

Deeb, B. S., and K. W. Sloan, 1975. "Nitrates, Nitrites, and Health," University of Illinois Colleges of Agriculture and Veterinary Medicine, Agricultural Experiment Station, Bulletin 750.

Dimond et al. (E. G. Dimond, J. Caravaca, and A. Benchimol), 1963. "Vanadium: Excretion, Toxicity, Lipid Effect in Man," Am. J. Clin. Nutr., Vol. 12, pp. 49-53.

Diswood, S., 1985. Navajo Fish and Wildlife Department, Navajo Nation, Window Rock, Arizona, personal communication to $\mathrm{C}$. Burt, Jacobs Engineering Group Inc., Albuquerque, New Mexico, August 27, 1985. 
Drever, J. I., 1982. The Geochemistry of Natural Waters, Prentice-Hall, Inc., Englewood Cliffs, New Jersey, 388p.

EES (Ecosphere Environmental Services), 1986. "A Threatened-Endangered Plant Species Survey for Two Uranium Tailings Piles-Monument Valley Site Monument Valley, Apache County, Arizona," prepared for Jacobs Engineering Group Inc., Albuquerque, New Mexico, by EES, Farmington, New Mexico.

EPA (U.S. Environmental Protection Agency), 1993. Integrated Risk Information System (IRIS), database, Office of Research and Development, Washington, D.C.

EPA (U.S. Environmental Protection Agency), 1992a. Health Effects Assessment Summary Tables, EPANOERR 920.6-303(92-1), Office of Research and Development, Office of Emergency and Remedial Response, Washington, D.C.

EPA (U.S. Environmental Protection Agency), 1992b. Final Drinking Water Criteria Document for Sulfate, Health and Environmental Criteria Division, Office of Science and Technology, Washington, D.C.

EPA (U.S. Environmental Protection Agency), 1992c. "Developing a Work Scope for Ecological Assessment," Eco Update, intermittent bulletin, Vol. 1, No. 4, Office of Emergency and Remedial Response, Hazardous Site Evaluation Division, Washington, D.C.

EPA (U.S. Environmental Protection Agency), 1990. Drinking Water Criteria Document for Stable Strontium, Office of Health and Environmental Assessment, prepared by the Office of Health and Environmental Assessment, Environmental Criteria and Assessment Office, Cincinnati, Ohio, for the Office of Drinking Water, Washington, D.C.

EPA (U.S. Environmental Protection Agency), 1989. Risk Assessment Guidance for Superfund, Vol. II, Environmental Evaluation Manual, EPA/540/1-89/001, Office of Emergency and Remedial Response, Washington, D.C.

EPA (U.S. Environmental Protection Agency), 1986. Quality Criteria for Water, EPA 440/5-86001, Office of Regulations and Standards, Washington, D.C.

EPA (U.S. Environmental Protection Agency), 1977. Scientific and Technical Assessment Report on Vanadium, EPA-600-6-77-002, U.S. Environmental Protection Agency, Washington, D.C.

EPA (U.S. Environmental Protection Agency), 1972. "Water Quality Criteria," National Academy of Sciences and National Academy of Engineering, Washington, D.C.

FBDU (Ford, Bacon and Davis Utah, Inc.), 1981. Engineering Assessment of Inactive Uranium Mill Tailings, Shiprock Site, Shiprock, New Mexico, DOE/UMT-0104 FBDU 360-02 UC 70, July 1981, prepared by Ford, Bacon and Davis Utah, Inc., for the U.S. Department of Energy, UMTRA Project Office, Albuquerque Operations Office, Albuquerque, New Mexico. 
Fisenne et al. (I. M. Fisenne, P. M. Perry, and N. H. Harley), 1988. "Uranium in Humans," Rad. Prot. Dosim., Vol. 24, pp. 127-131.

Follett, R. H., and P. N. Soltanpour, 1985. "Irrigation Water Quality Criteria," Colorado State University Extension Service, publication number 506.

Foxx et al. (T. S. Foxx, G. D. Tierney, and J. M. Williams), 1984. Rooting Depths of Plants on Low-Level Waste Disposal Sites, LA-10253-MS, Los Alamos National Laboratory, Los Alamos, New Mexico.

Freeze, R. A. and J. A. Cherry, 1979. Ground Water, Prentice-Hall, Inc., Englewood Cliffs, New Jersey.

Friberg et al. (L. Friberg, G. F. Nordberg, and V. B. Vouk), 1986. Handbook on the Toxicology of Metals, Volume II: Specific Metals, second edition, Elsevier, New York, New York.

Gosselin et al. (R. E. Gosselin, H. C. Hodge, and K. P. Smith), 1976. Clinical Toxicology of Commercial Products, fourth edition, Williams and Wilkins, Baltimore, Maryland.

Goyer, R. A., 1991. "Toxic Effects of Metals," Toxicology: The Basic Science of Poisons, fourth edition, M. O. Amdur, J. Doull, and C.D. Klaassen, eds., Pergamon Press, New York, New York, pp. 623-680.

Hadjimarkos, D. M., 1968. Adv. Oral Biol., Vol. 3, pp. 253-292.

Hadjimarkos, D. M., 1966. Nature, Vol. 209, pp. 1137.

Harris et al. (W. R. Harris, S. B. Friedman, and D. Silberman), 1984. Journal of Inorganic Biochemistry, Vol. 20, pp. 157-169.

Hill, S. R., and F. Titus, 1989. Appendix IX Special Study, Screening Contract No. DE-AC0482$A L 14086$, prepared for the U.S. Department of Energy by Jacobs Engineering Group.

House, D., 1985. Navajo Natural Heritage Program, Navajo Nation, Window Rock, Arizona, personal communication to Charles Burt, Environmental Services, Jacobs Engineering Group Inc., Albuquerque, New Mexico, December 13, 1985.

Hoy, W., 1993. Lovelace Medical Foundation, personal communication with J. Lewis, UMTRA Project, Jacobs Engineering Group Inc., Albuquerque, New Mexico, May 26, 1993.

ICRP (International Commission on Radiological Protection), 1960. ICRP Publ., 2.

Kamm et al. (L. Kamm, G. G. McKeown, and D. M. Smith), 1965. "New Colorimetric Method for the Determination of Nitrate and Nitrite Content in Baby Foods," J. Assoc. Office Agr. Chemists, Vol. 48, p. 892. 
Kondakis et al. (X. G. Kondakis, N. Makris, M. Leotsinidis, M. Prinou, and T. Papapetropoulos), 1989. "Possible Health Effects of High Manganese Concentration in Drinking Water," Archives of Environmental Health, 1989, Vol. 44, No. 3, pp. 175-178.

Lagerkvist et al. (B. Lagerkvist, G. F. Nordberg, and V. Vouk), 1986. "Vanadium," in Handbook on the Toxicology of Metals, second edition, L. Friberg, G. F. Nordberg, and V. Vouk, eds., Elsevier Science Publishers, New York, New York.

Leach et al. (L. J. Leach, R. M. Gelein, B. J. Panner, C. L. Ylie, and C. C. Cox), 1984. The Acute Toxicity of the Hydrolysis Products of Uranium Hexafluoride $\left(U F_{6}\right)$ When Inhaled by the Rat and Guinea Pig, final report, ISS KISUB-81-9039-3, NTIS DE84011539.

Lee, D. H. K., 1970. "Nitrates, Nitrites, and Methemolglobinemia," Environmental Research, Vol. 3, pp. 484-511.

Lönnerdal et al. (B. Lönnerdal, C. L. Keen, J. G. Bell, and B. Sandstrom), 1987. "Manganese Uptake and Retention," in Nutritional Bioavailability of Manganese, C. Kies, ed., American Chemical Society, Symposium Series 354, American Chemical Society, Washington, D.C., pp. 9-20.

Marie et al. (P. J. Marie, M. T. Garbu, M. Hott, and L. Miravet), 1985. "Effect of Low Doses of Stable Sr on Bone Metabolism in Rats," Miner. Electrolyte Metab., Vol. II, pp. 5-13.

Maynard, E. A., and H. C. Hodge, 1949. "Study of Toxicity of Various Uranium Compounds When Fed to Experimental Animals," in Pharmacology and Toxicology of Uranium Compounds, pp. 309-376, C. Voegtlin and H. C. Hodge, eds., National Nuclear Energy Services, Div. VI, Vol. 1, McGraw Hill, New York, New York.

McKee, J. E., and H. W. Wolf, 1963. Water Quality Criteria, second edition, J. E. McKee and H. W. Wolf, eds., California State Water Quality Control Board, Sacramento, California, p. 548.

Mena et al. (I. Mena, K. Horiuchi, K. Burke, and G. C. Colzias, 1969. "Chronic Manganese Poisoning: Individual Susceptiblity and Absorption of Iron," Neurology, No. 19, pp. 1000-1006.

Merritt, R. C., 1971. The Extractive Metallurgy of Uranium, Colorado School of Mines Research Institute, Library of Congress Catalog Card No. 71-157056.

NAS (National Academy of Sciences), 1974. Nutrients and Toxic Substances in Water for Livestock and Poultry, Subcommittee on Nutrient and Toxic Elements in Water, Committee on Animal Nutrition, Commission on Natural Resources, National Research Council, Washington, D.C.

NAS (National Academy of Sciences), 1972. "Accumulation of Nitrate," Committee on Nitrate Accumulation, Agricultural Board, Division of Biology and Agriculture, National Research Council, Washington, D.C. 
NCRP (National Council on Radiation Protection and Measurements), 1984. Exposure From the Uranium Series With Emphasis on Radon and Its Daughters, NCRP Report 77, Bethesda, Maryland.

NRC (National Research Council), 1973. Medical and Biological Effects of Environmental Pollutants: Manganese, Committee on Biologic Effects of Atmospheric Pollutants, Division of Medical Sciences.

NTAC (National Technical Advisory Committee to the Secretary of the Interior), 1968. Water Quality Criteria, U.S. Government Printing Office, Washington, D.C. Cited in EPA, 1986, Quality Criteria for Water, Office of Water Regulations and Standards, Criteria and Standards Division, Washington, D.C.

Opresko et al. (D. M. Opresko, B. E. Sample, and G. W. Suter), 1994. Toxicological

Benchmarks for Wildlife: 1994 Revision, ES/ER/TM-86/RI, U.S. Department of Energy, Oak Ridge National laboratory, Oak Ridge, Tennessee.

Parkhurst et al. (D. L. Parkhurst, D. C. Thorstenson, and D. N. Plummer), 1980. PHREEQE-A Computer Program for Geochemical Calculations, U.S. Geological Survey, Water Resources Investigation 80-96, National Technical Information Services Report PB81-167-801, Springfield, Virginia.

Pennington, J. A., and J. W. Jones, 1987. "Molybdenum, Nickel, Cobalt, Vanadium, and Strontium in Total Diets," in Journal of the American Dietetic Association, Vol. 87, No. 12, December 1987, American Dietetic Association, Division of Nutrition and Division of Contaminants Chemistry, Center for Food Safety and Applied Nutrition, Food and Drug Administration, Washington, D.C.

Perry et al. (H. M. Perry, Jr., S. Teitlebaum, and P. L. Schwartz), 1955. Fed. Proc., Vol. 14, pp. 113-114.

Prister, B. S., 1969. GKIAE Report by Atomizdat, Moscow (Canadian translation AEC/TR/7178 (1970), and USCEAR Rep. AVAC.82/G/L 1298).

Proescher et al. (F. Proescher, H. A. Seil, and A. W. Stillians), 1917. Am. J. Syph., Vol. 1, pp. 347-405.

Rawson, D. S., and J. E. Moore, 1944. "The Saline Lakes of Saskatchewan," Canadian Journal of Research, 22:141. Cited in EPA, 1986, Quality Criteria for Water, Office of Water Regulations and Standards, Criteria and Standards Division, Washington, D.C.

Roseberry, A. M., and D. E. Burmaster, 1992. "Lognormal Distributions for Water Intake by Children and Adults," in Risk Analysis, Vol. 12, No. 1, pp. 99-104.

Ruesink, R., 1985. U.S. Fish and Wildlife Service, Endangered Species Office, Salt Lake City, Utah, personal communication with David Lechel, Environmental Services, Jacobs Engineering Group Inc., Albuquerque, New Mexico, September 23, 1985. 
Saric, M., 1986. "Manganese," Handbook on the Toxicology of Metals, Volume II, L. Friberg, G. F. Nordberg, and V. B. Vouk, eds., Elsevier, New York, pp. 354-386.

Schroeder et al. (H. A. Schroeder, J. J. Balassa, and I. H. Tipton), 1963. Journal of Chronic Diseases, Vol. 16, pp. 1047-1071.

Shacklette, H. T., and J. G. Boerngen, 1984. Element Concentrations in Soils and Other Surficial Materials of the Conterminous United States, U.S. Geological Survey Professional Paper 1270, U.S. Government Printing Office, Washington, D.C.

Smith, G. E., 1966. "Causes of nitrate accumulation in plants and water supplies," paper to 18th annual Midwest Fertilizer Conference, Chicago, Illinois.

Snyder, F., and W. E. Cornatzer, 1958. Nature, Vol. 182, pp. 462.

Snyder et al. (W. S. Snyder, M. J. Cook, E. S. Nassat, L. R. Karhause, G. P. Howells, and I. H. Tipton), 1975. International Commission on Radiological Protection (ICRP), Report of the Task Group on Reference Man, ICRP Publ. 23, New York, New York.

Somerville, J., and B. Davies, 1962. Am. Health J., Vol. 54, pp. 54-56.

Stevens et al. (W. F. Stevens, W. Bruenger, D. R. Atherton, J. M. Smith, and G. N. Taylor), 1980. "The Distribution and Retention of Hexavalent ${ }^{233} U$ in the Beagle," Radiat. Res., Vol. 83, pp. 109-126.

Storey, E., 1961. "Strontium 'Rickets' Bone Calcium and Strontium Changes," Austral. Ann. Med., Vol. 10, pp. 213-222.

Sullivan et al. (M. F. Sullivan, P. S. Ruemmler, J. L. Ryan, and R. L. Bushhom), 1986. "Influence of Oxidizing or Reducing Agents on Gastrointestinal Absorption of $\mathrm{U}, \mathrm{Pu}$, Am, Cm, and Pm by Rats," Health Physics, Vol. 50, pp. 223-232.

Summerskill, W. H. J., and E. Wolpert, 1970. "Ammonia Metabolism in the Gut," American Journal of Clinical Nutrition, Vol. 23, pp. 633-639.

Tank, G., and C. A. Storvick, 1960. "Effect of Naturally Occurring Selenium and Vanadium on Dental Caries," Journal of Dental Research, Vol. 39, pp. 473-488.

Tipton et al. (I. H. Tipton, P. L. Stewart, and J. Dickson), 1969. Health Phys., Vol. 9, pp. 103145.

Tracy et al. (B. L. Tracy, J. M. Quinn, J. Lahey, A. P. Gilman, K. Mancuso, A. P. Yagdinas, and D. C. Villeneuve), 1992. "Absorption and Retention of Uranium From Drinking Water by Rats and Rabbits," Health Physics, Vol. 62, pp. 65-73. 
Tracy et al. (B. L. Tracy, F. A. Prantl, and J. M. Quinn), 1983. "Transfer of ${ }^{226} \mathrm{Ra}{ }^{210} \mathrm{~Pb}$, and Uranium from Soil to Garden Produce: Assessment of Risk," Health Physics, Vol. 44, p. 469.

Van Zinderen Bakker and J. F. Jaworski, 1980. Effects of Vanadium the Canadian Environment, Ottawa, Canada: National Research Council Canada, Associate Committee Scientific Criteria for Environmental Quality.

Weigel, F., 1983. "Uranium and Uranium Compounds," Kirk-Othmer Encyclopedia of Chemical Technology, Vol. 23, third edition, M. Grayson, ed., John Wiley and Sons, New York, New York, pp. 502-547.

WHO (World Health Organization), 1988. Vanadium, Environmental Health Criteria 81, published under the joint sponsorship of the United Nations Environment Programme, the International Labour Organisation, and the World Health Organization, Geneva, Switzerland.

Will, M. E., and G. W. Suter II, 1994. Toxicological Benchmarks for Screening Potential Contaminants of Concern for Effects on Terrestrial Plants: 1994 Revision, TN ES/ER/TM-85/R1, Oak Ridge National Laboratory, Oak Ridge, Tennessee.

Witkind, I. J., and R. B. Thaden, 1963. "Geology and Uranium-Vanadium Deposits of the Monument Valley Area, Apache and Navajo Counties, Arizona," U.S. Geological Survey Bulletin, No. 1103, U.S. Government Printing Office, Washington, D.C.

Wrenn et al. (M. E. Wrenn, P. W. Durbin, B. Howard, J. Lipsztein, J. Rundo, E. T. Still, and D. L. Willis), 1985. "Metabolism of Ingested U and Ra," Health Physics, Vol. 48, pp. 601-633.

Yakawa, M., and M. Suzuk-Yasumoto, 1980. Arch. Environ. Health, Vol. 35, pp. 36-44.

\section{CODE OF FEDERAL REGULATIONS}

40 CFR Part 192, Health and Environmental Protection Standards for Uranium and Thorium Mill Tailings, U.S. Environmental Protection Agency.

40 CFR Part 264, Standards for Owners and Operators of Hazardous Waste Treatment, Storage, and Disposal Facilities, U.S. Environmental Protection Agency.

\section{UNITED STATES CODE}

42 USC §7901, Uranium Mill Tailings Radiation Control Act, 8 November 1978. 